\title{
Tephrochronology and its application: a review
}

\author{
David J. Lowe* \\ Department of Earth and Ocean Sciences, University of Waikato, \\ Private Bag 3105, Hamilton 3240, New Zealand
}

Quaternary Geochronology 6 (2011), 107-153.

DOI: 10.1016/j.quageo.2010.08.003

Final pre-publication version (8 Oct 2010)

*Phone: +64 7 838-4438, Fax: +64 7 856-0115.

E-mail addres: d.lowe@waikato.ac.nz 


\begin{abstract}
Tephrochronology (from tephra, Gk 'ashes') is a unique stratigraphic method for linking, dating, and synchronizing geological, palaeoenvironmental, or archaeological sequences or events. As well as utilizing the Law of Superposition, tephrochronology in practise requires tephra deposits to be characterized (or 'fingerprinted') using physical properties evident in the field together with those obtained from laboratory analyses. Such analyses include mineralogical examination (petrography) or geochemical analysis of glass shards or crystals using an electron microprobe or other analytical tools including laser-ablation-based mass spectrometry or the ion microprobe. The palaeoenvironmental or archaeological context in which a tephra occurs may also be useful for correlational purposes. Tephrochronology provides greatest utility when a numerical age obtained for a tephra or cryptotephra is transferrable from one site to another using stratigraphy and by comparing and matching inherent compositional features of the deposits with a high degree of likelihood. Used this way, tephrochronology is an age-equivalent dating method that provides an exceptionally precise volcanic-event stratigraphy. Such age transfers are valid because the primary tephra deposits from an eruption essentially have the same short-lived age everywhere they occur, forming isochrons very soon after the eruption (normally within a year). As well as providing isochrons for palaeoenvironmental and archaeological reconstructions, tephras through their geochemical analysis allow insight into volcanic and magmatic processes, and provide a comprehensive record of explosive volcanism and recurrence rates in the Quaternary (or earlier) that can be used to establish time-space relationships of relevance to volcanic hazard analysis.

The basis and application of tephrochronology as a central stratigraphic and geochronological tool for Quaternary studies are presented and discussed in this review. Topics covered include principles of tephrochronology, defining isochrons, tephra nomenclature, mapping and correlating tephras from proximal to distal locations at metre- through to sub-
\end{abstract}


millimetre-scale, cryptotephras, mineralogical and geochemical fingerprinting methods, numerical and statistical correlation techniques, and developments and applications in dating including the use of flexible depositional age-modelling techniques based on Bayesian statistics. Along with reference to wide-ranging examples and the identification of important recent advances in tephrochronology, such as the development of new geoanalytical approaches that enable individual small glass shards to be analysed near-routinely for major, trace, and rare-earth elements, potential problems such as miscorrelation, erroneous-age transfer, and tephra reworking and taphonomy (especially relating to cryptotephras) are also examined. Some of the challenges for future tephrochronological studies include refining geochemical analytical methods further, improving understanding of cryptotephra distribution and preservation patterns, improving age modelling including via new or enhanced radiometric or incremental techniques and Bayesian-derived models, evaluating and quantifying uncertainty in tephrochronology to a greater degree than at present, constructing comprehensive regional databases, and integrating tephrochronology with spatially referenced environmental and archaeometric data into 3-D reconstructions using GIS and geostatistics.

\section{Keywords}

Tephras; cryptotephras; tephrostratigraphy; tephrochronology; tephrochronometry; tephra fingerprinting; age-equivalent dating; dating tool; isochrons; chronostratigraphy; magnetostratigraphy; correlation; miscorrelation; petrography; electron microprobe; LA-ICPMS; ion probe; volcanic event stratigraphy; uncertainty; taphonomy 


\section{Introduction}

Tephra studies have become increasingly important in Quaternary research as the need to provide high-resolution palaeoenvironmental or archaeological records, and to synchronize and date such records, has become an urgent focus in a range of globally important projects such as INTIMATE (Integration of ice core, marine, and terrestrial records: refining the record of the last glacial-interglacial transition), SUPRAnet (Studying uncertainty in palaeoenvironmental reconstruction - a net), and RESET (Response of humans to abrupt environmental transitions) (Froese et al., 2008; Lowe, 2008a; Lowe et al., 2008a, 2008b). Tephras alone, once securely identified, provide the means to link and synchronize such records accurately and also to transfer ages from one site to the next where the tephras have been dated by radiometric, incremental, or other methods. In addition, tephra sequences provide a key source of data on the geochemistry and eruption frequency of volcanoes and the interrelationships between eruption sequences spatially and temporally (e.g., Shane, 2000, 2005; Carter et al., 2003). Increasing numbers of Quaternary studies therefore have tephras at their chronological core and hence it is appropriate to review the discipline that facilitates their use, namely tephrochronology.

For many Quaternarists, tephrochronology is some sort of specialist (perhaps even mystifying) 'black box' into which complex data disappear to later emerge as named chronostratigraphic units or as a framework underpinning an age model. Here, I lift the lid on this 'box' and review the principles, nomenclature, and methodology of tephrochrononology, and illustrate its functioning and application as a geochronological tool with examples across a range of disciplines pertaining to the Quaternary. Some of the problems and pitfalls, hence uncertainty, that may arise in undertaking tephrochronology, not often openly discussed, are also covered. Examples derive both from New Zealand and elsewhere. They also include reference to novel work being undertaken on non-visible tephras, referred to as cryptotephras which typically 
comprise glass-shard or crystal concentrations, along with a string of other seminal advances in the discipline in recent years.

Previous reviews dealing with tephrochronology since 2000 include those of SarnaWojcicki (2000), Shane (2000), Turney and Lowe (2001), Dugmore et al. (2004), Turney et al. (2004), and Alloway et al. (2007a). Wide-ranging volcanological aspects of tephra studies were reported in detail by Sparks et al. (1997) and Sigurdsson (2000); Houghton et al. (2000) reviewed pyroclastic fall deposits.

\section{Principles of tephrochronology (and some problems)}

\subsection{Principles}

Tephrochronology is a unique method for linking and dating geological, palaeoecological, palaeoclimatic, or archaeological sequences or events. Few if any geochronological methods can match the precision it offers temporally and spatially. The method relies firstly, and most critically, on stratigraphy and the Law of Superposition, which apply in any study that connects or correlates deposits in one place to those at another (e.g., Feibel, 1999). Secondly, it requires tephra layers to be characterized and hence identified or 'fingerprinted' using either physical properties evident in the field or various properties obtained from laboratory analyses. These laboratory methods may include mineralogical (petrographic) examination by optical microscopy or geochemical analysis of glass shards or loose mineral grains (free crystals) using the electron microprobe and other analytical instruments. The palaeoenvironmental or palaeoecological context in which a tephra occurs may also be useful for correlational purposes (Lowe et al., 2010; Preece et al., in press). Thirdly, the method is strongly enhanced, and provides greatest value, when a numerical age or calendrical date is obtained for a tephra layer by one or more dating methods. That numerical age or date can then be transferred from one site to another using 
stratigraphic methods and by matching compositional characteristics - i.e., by comparing 'fingerprints' from each tephra layer. Used this way, tephrochronology is an age-equivalent dating method.

Although a known (well-characterized) tephra layer or cryptotephric glass-shard or crystal concentration zone may sometimes be dated imprecisely, the layer/concentration zone still provides a time-plane that allows the sequence in which it is found to be correlated with other sequences where the same tephra or concentration zone occurs. Herein lies the unique power of tephrochronology: deposits with their palaeoarchival evidence are able to be synchronized positioned very precisely on a common time-scale - using the tephra layer or cryptotephra glass/crystal concentration as a stratigraphically fixed tie-point (even if the tephra age is uncertain or unknown). In this situation, the age scale is best envisaged as a length of elastic that can be stretched or contracted when a numerical age is obtained, or age precision improved, whilst the tephra's stratigraphic juxtaposition with respect to enclosing deposits and archival data remains firmly fixed on the 'elastic'. If the tephra age is well known, however, that age can be applied directly to the sequence where the tephra or cryptotephra has been newly identified. The age transfer, a key principle in tephrochronology, is valid because tephras are erupted and deposited effectively instantaneously with respect to geological time scales. This assertion is supported by briefly considering, in the following four paragraphs, the duration of tephra eruptions and the time taken for tephra from eruption plumes to fall through the atmosphere onto land (including lake beds), through the ocean to the sea bed, or onto polar or alpine ice sheets.

(1) Tephras are erupted over very short time periods: most volcanic eruption episodes, especially very explosive, tephra-generating phases, typically last for just hours or days, some perhaps weeks or months (Fig. 1; discussed further in Section 2.3 below). 


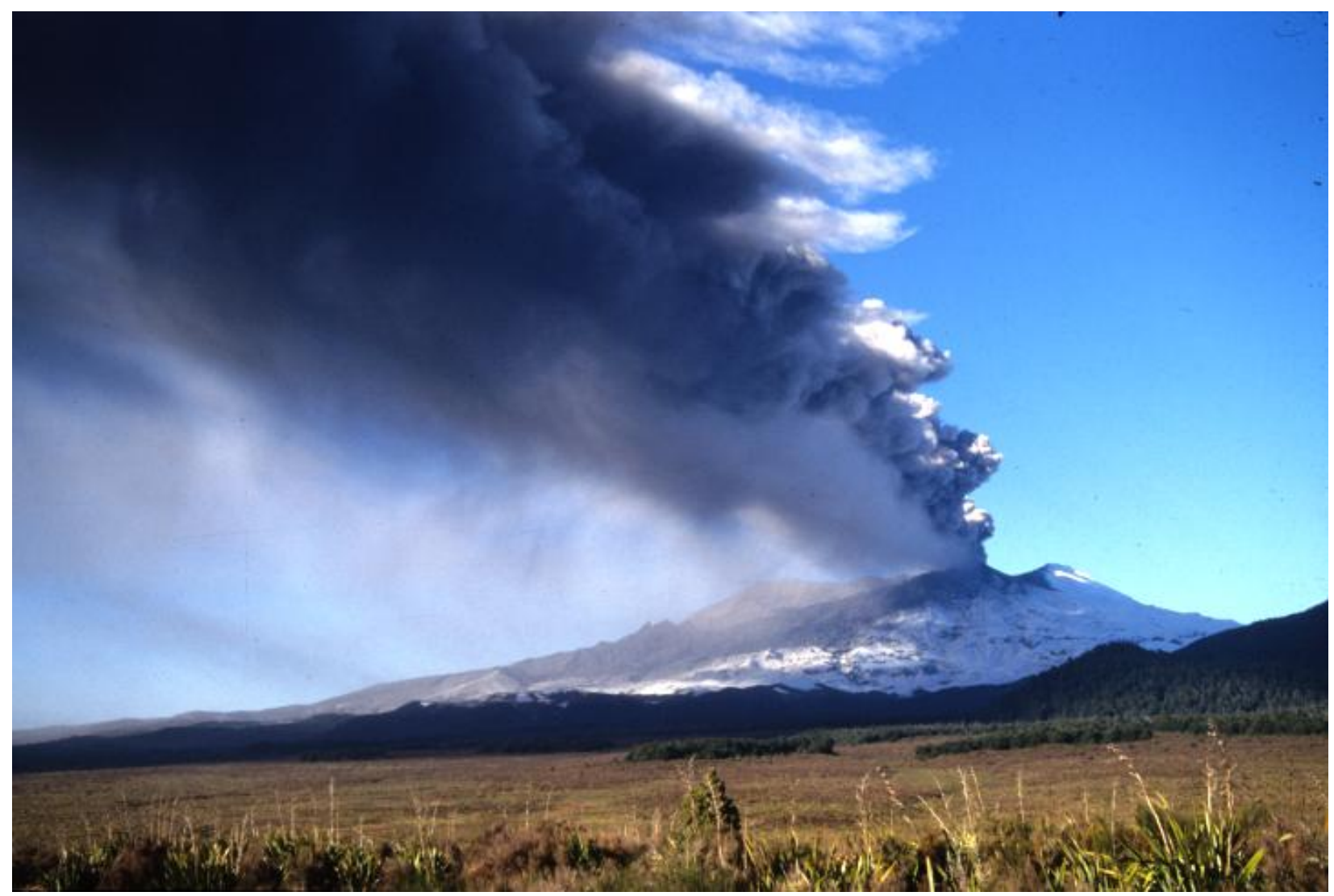

Fig. 1. Erupting wind-borne tephra plume from Mt Ruapehu, North Island, New Zealand, at $\sim 1230$ hours, 18 June, 1996. The ash being deposited rapidly on the snow, turning it grey, and on the land beyond, provides an isochron or 'time-parallel' marker bed in the stratigraphic record (i.e., it has essentially the same age, within about 24 hours, wherever it occurs). Subsequent tephra-generating eruptions of Ruapehu continued sporadically until mid-July, 1996 (see text). Photo: D.J. Lowe

(2) The solid particles of glass, crystals, pumice, and rock fragments (lithics) that make up erupting tephra plumes fall through the atmosphere very rapidly, usually on time scales of minutes to a few days (unlike aerosol components that can remain in the stratosphere for some years) (Mills, 2000; Robock, 2002; Rose and Durant, 2009). Once an ash cloud becomes visible then particles of ash are likely to be deposisted on the ground within $\sim 2$ hours (Harris et al., 1981). Although tephra plumes or ash clouds may remain aloft in the atmosphere to be blown vast distances (e.g., tephra erupted from Mt Spurr in Alaska in September, 1992, was blown at least $5000 \mathrm{~km}$ ), such persistence still amounts to a matter of days (e.g., Miller and Casadevall, 2000). For example, ash erupted from Mt St Helens on 18 May, 1980, was blown a distance of $\sim 1000 \mathrm{~km}$ in only 10 hours (Christiansen and Paterson, 1981). Rose and Durant (2009) showed 
that ash cloud mass can decrease by an order of magnitude in 24 hours, with rapid fallout of very fine ash occurring as 'mass deposition' through meterological aggregation processes a few hundred kilometres downwind.

(3) The time taken for tephra particles to sink to the sea bed or lake bottom is rapid, although depositional processes in the sea can be complex (Manville and Wilson, 2004). Deepwater sediment traps in the South China Sea $586 \mathrm{~km}$ west of Mt Pinatubo, at $1190 \mathrm{~m}$ and $3730 \mathrm{~m}$ water depths, intercepted ash within three days of the paroxysmal phase of the Pinatubo eruption of 15 June, 1991, indicating that vertical oceanic settling velocities were $>2 \mathrm{~cm} / \mathrm{s}$ (Wiesner et al., 1995; Manville and Wilson, 2004; Wetzel, 2009). This rate of sinking, dramatically faster than would be expected from individual particle settling under Stokes Law, showed that finer grains plummeted to the sea bed by vertical density (gravity) currents as rapidly-descending turbid megaplumes (Carey, 1997; Manville and Wilson, 2004). Sharp bases, gradational or bioturbated upper contacts, and the overwhelming dominance of fresh glass (and paucity of plankton) in marine tephras also point to rapid vertical settling (Carter et al., 1995; Manville and Wilson, 2004). Carey (1997, p.839) concluded that such vertical density settling substantially "reduces the residence time of fine ash in the ocean and diminishes the role of ocean currents in influencing the distribution patterns of individual tephra layers".

(4) The time period for the deposition of glass shards and aerosols from an eruption plume on the polar ice sheets is variable and depends on latitude and season and stratospheric processes as well as the volcanic eruption dynamics (Trepte and Hitchman, 1992; Pyle, 1998). Aerosol deposition on Greenland or Antarctica can lag the eruption by one to two years because of atmospheric transport times (Fiacco et al., 1994; Zielinski et al., 1994; Cole-Dai et al., 2000, 2009; Robock, 2002). Zielinski et al. (1997) recorded that glass shards erupted from El Chichón in Mexico in late March-early April, 1982, reached the Greenland Summit region in spring snow deposits in 1983 - i.e., about 1 year after the eruption. 
To summarise, unless it has been reworked long after deposition, a tephra layer from a powerful eruption, spread widely over land, sea, and ice, as a thin blanketing deposit has effectively an identical age - an isochron - wherever it occurs to within about a year. Thus, for example, the Icelandic Vedde Ash, dated at ca. 12.1 ka calendar (cal) BP in Greenland's NGRIP ice core, forms a widespread isochronous marker bed in the Greenland ice sheet, in marine deposits in the North Atlantic, and in terrestrial sequences in northern Europe, eastern Europe, and central Europe as far south as the Swiss Alps (Blockley et al., 2007a; Davies et al., 2010a). Therefore palaeoarchives in these widely separated localities (up to $\sim 2500 \mathrm{~km}$ from Iceland) can be connected precisely to the same point in time, namely the specific year of the Vedde eruption, assuming that the tephra at each location comprises essentially primary fallout material. Similarly the Kawakawa/Oruanui tephra, erupted from northern New Zealand ca. 27.1 ka cal BP, forms a key isochron linking numerous terrestrial and marine sequences extending more than $1500 \mathrm{~km}$ across the New Zealand and southwest Pacific region near the start of marine oxygen isotope (MOI) stage 2 (Newnham et al., 2007a; Lowe et al., 2008a, 2010; Holt et al., 2010). At each location, the Kawakawa/Oruanui tephra deposit represents a time span probably of just a few months over which the entire eruption episode took place (Wilson, 2001; Manville and Wilson, 2006), together with the short times needed for atmospheric dispersion and marine settling.

Gale (2009), in overviewing event chronostratigraphy, was therefore correct in describing tephra-fall deposits as perhaps the most valuable chronostratigraphic marker for short-lived events, especially for the late Quaternary period. Tephra layers or cryptotephric glass-shard or crystal concentrations thus provide an exceptionally precise volcanic-event stratigraphy (Lowe et al., 2007). A crucial warning here, however, is that tephras, when well characterized, enable sequences to be aligned with remarkable precision and reliability, as emphasised already, but if a tephra is unwittingly misidentified or miscorrelated, or if an inaccurate or erroneous age is transferred, then problems will arise in synchronization and age modelling (Lowe et al., 2009; Blaauw et al., 2010; Blaauw, submitted for publication). Secondly, if a tephra layer is reworked, 
or cryptotephric glass shards or crystals extensively dispersed, then the interpretation of the reworked or disseminated tephric materials is complex and the deposits are less viable as an isochron (reworking is discussed further in Section 5.4).

\subsection{Miscorrelation and erroneous-age transfer}

Miscorrelation can arise in many ways including the following situations (the examples cited describe some aspects of each situation) (after Lowe, 2008b):

(1) by stratigraphic error in field work (e.g., Lowe, 1986a; Hay, 1992);

(2) by assigning an incorrect age unwittingly to a tephra from which subsequent faulty agebased correlations are made (e.g., Lowe, 1986a; Kohn et al., 1992; Roulleau et al., 2009);

(3) incompleteness of stratigraphic records of tephra-erupting episodes against which to attempt correlation (e.g., Alloway et al., 1994; Davies et al., 2004a; Newton et al., 2007; Fiske et al., 2009);

(4) paucity or inadequacy of characterization data of potential correlatives, especially in proximal areas where the deposits may be compositionally complex such as in preHolocene eruptives in Iceland (e.g., Larsen and Eiríksson, 2007), or in New Zealand where, for example, many proximal tephras from Egmont/Taranaki volcano have not been characterized geochemically (Shane, 2005);

(5) lack of recognition that tephra desposits from one eruption episode may have 'multiple fingerprints' temporally and spatially because of magmatic changes during their eruption (e.g., Shane et al., 2008a), or because of the presence of small mineral micro-inclusions chiefly in andesitic or basaltic glasses (described further below);

(6) by tephras having closely similar and therefore ambiguous compositions - i.e., non-unique ‘fingerprints' (e.g., Brendryen et al., 2010); 
(7) by inappropriate geochemical analysis leading to faulty or inadequate characterization so that analytical data are compromised (e.g., Pearce et al., 2004b; Denton and Pearce, 2008);

(8) by reworking of a tephra (or dispersal of cryptotephric glass shards or crystals) to a different stratigraphic position (e.g., Boygle, 1999; Dugmore et al., 2004; Gehrels et al., 2006; Shane et al., 2006; Payne and Gehrels, 2010; Pyne-O'Donnell, in press);

(9) by 'swamping' of a stratigraphic record with large numbers of chemically indistinguishable glass shards (e.g., from a single eruption or a single volcanic source that has produced closely-spaced eruptives compositionally very similar in character), so that sparsely represented tephras or cryptotephras in the sequence are missed (e.g., Smellie, 1999; Hillenbrand et al., 2008);

(10) by replication of sequences of tephra-bearing sediments in lacustrine or marine cores because of localised slumping and redepositition (Pickrill et al., 1991; Manville and Wilson, 2004), or because of repeated fluvial or aeolian input as a consequence of prolonged landscape instability (Manville and Wilson, 2006; Shane et al., 2006), or because of faulty core retrieval (Allan et al., 2008);

(11) by uncritical attribution of a tephra, for example, to an acid peak in an ice core without supportive compositional data derived from geochemical analysis of associated glass shards (e.g., de Silva and Zielinksi, 1998; Lowe and Higham, 1998; Lowe and de Lange, 2000; Traufetter et al., 2004; Blaauw and Wohlfarth, 2010; Blaauw, submitted for publication); or

(12) by statistical misadventure whereby miscorrelation may arise, for example, in discriminant function analysis because the database/training set is not comprehensive or because compositional data are of poor or variable quality (Lowe et al., 2007; Lowe et al., 2008a).

Where an incorrect age is assigned to a widespread marker tephra, the consequences can be substantial, as occurred for example in New Zealand with the mid-Quaternary Rangitawa/Mt Curl 
tephra. Originally dated by glass-based fission track analysis, the age of ca. 230 ka obtained for the tephra was underestimated because of partial annealing (fading) and led to it being assigned erroneously to MOI stage 8 for nearly 20 years (Milne et al., 1973; Froggatt et al., 1986).

Subsequent dating by zircon fission-track analysis (Kohn et al., 1992), and other methods including spectral analysis of marine sediments (Black et al., 1988; Nelson, 1988) and isothermal-plateau fission-track (ITPFT) dating on glass that corrects for annealing (Alloway et al., 1993), resulted in a new age of ca. 340 ka being obtained for the tephra and hence correct reassignment to late MOI stage 10 (Pillans et al., 1996; Lowe et al., 2001; Holt et al., 2010). Consequently, the possibility of tephra miscorrelation or the assignment of an erroneous age, and attendant impacts on tephrochronological application, need careful consideration in developing age models especially. Evaluating and improving the quantification of uncertainty in tephrochronology thus are key objectives in the INTREPID and SUPRAnet projects (Lowe et al., 2009).

\subsection{Defining 'isochronous' and 'isochrons'}

As noted previously, many volcanic eruption episodes, especially very explosive, tephragenerating phases, typically last for only minutes, hours, or days to perhaps weeks or months, and rarely extend beyond a year or two. The resultant tephras demonstrably represent short-lived isochronous time-lines in the context of geological time - at the most, only months or so in duration, commonly considerably less as shown by the following set of examples.

The Tarawera eruption (a basaltic plinian eruption) in central North Island, New Zealand, on 10 June 1886, lasted around four hours. The explosive plinian phase of the previous eruption of Mt Tarawera, the rhyolitic Kaharoa eruption in ca. 1314 AD, lasted an estimated $~ 57$ hours (Nairn et al., 2004). In Kamchatka, Russia, the major explosive phase of the eruption of Klyuchevskoy volcano in October, 1994, lasted $~ 36$ hours (intense for $\sim 10$ hours) (Miller and 
Casadevall, 2000). Widespread fall deposits of the Bishop Tuff super-eruption from Long Valley Caldera (ca. $760 \mathrm{ka}$ ), eastern California, accumulated in an estimated 90-140 hours (Wilson and Hildreth, 1997; Wilson, 2008). In Peru, the Huaynaputina plinian eruption in early 1600 AD lasted 16 days including several periods of quiescience (Adams et al., 2001). In contrast, the Redoubt eruption in Alaska in 1989-1990 comprised over 20 explosive episodes within a fivemonth period (Miller and Casadevall, 2000). The entire Kawakawa/Oruanui rhyolitic supereruption (ca. $27.1 \mathrm{ka}$ cal BP) occurred over a period of several months, mostly consisting of periods for which no record of activity is preserved interspersed with spasmodic, short-lived periods of intense activity of increasing vigour "daisy-chained into a single geological event" (Wilson, 2001, 2008).

Turning to longer-lived eruptions, the most recent sizeable tephra-producing eruptions of the andesitic stratovolcano Mt Ruapehu in central North Island took place in two series of outbursts (or 'events' using the nomenclature of Jenkins et al., 2007), each comprising 'stages' or 'pulses' together lasting about four weeks in 1995 and in 1996 (Cronin et al., 2003). The total duration of the 1995-96 episode, including minor activity (gas and steam emissions) or no activity, was 20 weeks (Johnson et al., 2000). The first series began on 18 September 1995 with further minor eruptions on 20,23, 25 September, and 7 October; two sustained stages, resulting in widespread ash dispersal, then occurred on 11 October ( 8 hours in duration) and 14 October (5 hours). The second series began eight months later with a sustained eruption lasting about 24 hours on 17-18 June 1996 (Fig. 1) with further sizeable tephra-plume-emitting events on 27 June, 7 July, 15 July, and finally 19 July 1996. In this case, two key aspects define the tephras as isochrons: firstly, the widespread tephras represent short-lived eruption events lasting a matter of hours (including time to fall through the atmosphere); and secondly the entire sequence of tephras (i.e., all the explosive eruptives) has the same age (within 10 months at most, from 18 September 1995 to 19 July 1996) wherever the component tephras occur, meaning they are isochronous, not diachronous. 
In other cases, however, eruption episodes can be more prolonged with sporadic or moreor-less continuous activity extending over some years or even decades (Jenkins et al., 2007). For example, andesitic Whakaari (White Island) in northern New Zealand was essentially continuously active from 1976 to 1982, and in southern Japan, andesitic Sakurajima volcano has erupted tephras on and off since 1955, with current activity being regarded as part of the 19552010 (continuing) eruption cycle (by May 2010, more than 8667 short-lived eruptions had been recorded since 1955: Kobayashi, 2010). Basaltic eruption episodes of essentially continuous activity lasting a few years to a few decades can also occur, such as the Pu'u'O'o-Kupaianaha eruption of Kilauea volcano, Hawaii, which has been in progress since 1983 with more than 55 eruption episodes (many of them effusive rather than explosive) recorded since then (http://hvo.wr.usgs.gov/kilauea/summary/).

In these cases of prolonged eruption events or episodes the question therefore arises regarding the use of associated tephra deposits as 'isochrons' because of the length of time that such deposits represent. In some ways the argument is semantic and relates partly to the length of time acceptable or definable as being 'short-lived' in the geological record, and hence tends to be related to the geochronological context of the investigation (e.g., defining abrupt ENSO changes versus orbitally-induced 100-ka cycles). Partly the issue boils down also to how the constituent tephras are defined as stratigraphic units. For example, a series of thin tephra layers deposited incrementally over many years but appearing as a 'seamless' non-differentiated unit, such as at Sakurajima, does represent an isochronous unit that spans 55 years - not quite 'instantaneous' but nevertheless exactly the same 55-year time-span wherever it occurs because the base marks year1 (1955) and the top marks year-55 (2010) of the eruption sequence (as at the time of writing). So the 1955-2010 package of Sakurajima tephras represents a relatively short-lived 'event' (eruptive episode) that has the same age (within 55 years) wherever the constituent tephras occur, meaning the package as a whole is isochronous, as for the Mt Ruapehu example noted above. But this 1955-2010 Sakurajima isochron has a 55-year error margin and therefore (putting aside issues of 
tephra distribution) is likey to be of slightly lesser utility in tephrochronology than one encompassing a much shorter time span. Individual beds (each marking eruptive activity on Sakurajima of the order of minutes) making up the 1955-2010 deposits, if able to be identified geochemically or mineralogically, and which can be attributed to a specific eruption date, have the potential to provide useable (very) short-lived isochrons.

Extending beyond the present to the recent geological past, Fiske et al. (2009), in evaluating the eruptive history of Kilauea volcano for the past several thousand years, identified a sequence of previously unrecognised basaltic tephras dated between ca. 400 and 1000 AD. Because the sequence (collectively named Kulanaokuiki Tephra) represents 600 years, it cannot be regarded as 'short-lived' but nevertheless it is isochronous because the upper and lower bounding units (assuming no reworking) have the same age wherever they occur. One tephra member within the sequence (Kulanaokuiki-2) has distinctive geochemical and palaeomagnetic features that allow it to be identified uniquely and so it represents a 'short-lived' isochron (dated between ca. 440-650 AD at $95 \%$ probability) (Fiske et al., 2009).

In New Zealand, many of the andesitic tephras derived from Tongariro or Egmont stratovolcanoes are composed of multiple units deposited incrementally during eruptive episodes similar to those described above. One example is the Tufa Trig Formation, which comprises 19 defined tephra members or units (Tf-1 to Tf-19) derived from Mt Ruapheu (Donoghue et al., 1997). Some of the defined units themselves may be composites that represent the products of several closely-spaced eruption episodes. The basal unit Tf- 1 overlies a regional rhyolitic marker bed, Taupo tephra (232 \pm 5 AD) (Hogg et al., 2009), and the topmost unit Tf-19 represents the 1995-1996 eruptives. Thus, as a group, the deposits (Tufa Trig Fm.) represent an isochronous pair of time-lines spanning nearly 2000 years between ca. 232 AD (base) and 1996 AD (top). Perhaps such a 'broad' isochron could be called 'composite'. The members are compositionally distinct from older (pre-ca. 232 AD) tephras and from tephra deposits from other other volcanoes in the Tongariro Volcanic Centre (Donoghue et al., 1997). Individual members are mappable and 
most have had ages assigned to them, therefore providing potentially useful isochrons: for example, Tf-5, Tf-6, and Tf- 8 have been identified and used as marker beds in studies on lake deposits in eastern North Island (Eden and Froggatt, 1996; Wilmshurst et al., 1997).

In summary, tephras arising from short-lived eruptions that take place over hours to months or even a year (including atmospheric fallout, or the time taken for particles to sink through a water column) are easily envisaged as 'short-lived' isochrons that provide isochronous spatial markers which essentially have the same age wherever they occur, assuming minimal or no reworking. Each tephra marks a 'moment in time', using the terminology of Dugmore et al. (2004). Tephras arising from frequently-erupting volcanoes and which tend to accumulate incrementally into composite packages of stratigraphically-contiguous tephra layers over longer time periods (marking the 'passage of time', Dugmore et al., 2004), from years to decades through to centuries or millennia, such as the Tufa Trig Formation, are still able to provide isochronous surfaces except that the isochron comprises in effect a pair of maximum and minimum time-lines, namely the eruption dates for the lowermost and uppermost tephras, respectively. Such 'composite' isochrons may span several hundreds or thousands of years and hence are of less utility in high-resolution geochronological studies but nonetheless may still provide useful chronostratigraphic markers in some circumstances.

\section{Tephra-related nomenclature}

Tephras, from the Greek word $\tau \varepsilon \dot{\varphi} \varphi \alpha$ (tephra) meaning 'ashes', comprise all the explosively-erupted, unconsolidated pyroclastic (fragmental) products of volcanic eruptions (Table 1). They include both fall deposits and those arising from pyroclastic density currents (pyroclastic flows or surges) so long as they remain unconsolidated. Welded or hardened pyroclastic materials should not normally be described as tephra. The adjective 'pyroclastic' (Greek pur 'fire', klastos 'broken in pieces') is nearly synonymous with tephric but additionally 
encompasses deposits that have been welded (by the sintering together of hot pumiceous

fragments and glass shards under a compactional load) to form hard rock (Froggatt and Lowe,

1990). 'Tephra' has a compelling linguistic symmetry with the volcanologically-related terms

'lava' and 'magma' and it has historical connections with classical volcanology of the

Mediterranean region where the term was first recorded in the Western literature by Aristotle ca.

350 BC (Thorarinsson, 1981).

\section{Table 1}

Tephra-related nomenclature in brief.

Term Definition

Tephra

Cryptotephra

Tephrochronology (sensu stricto)

All the explosively-erupted, unconsolidated pyroclastic products of a volcanic eruption (Greek tephra, 'ashes')

Tephra-derived glass-shard or crystal concentration, or both, preserved in sediment (including ice) or soil and not visible as a layer to the naked eye (Greek kryptein, 'to hide')

Tephrostratigraphy Study of sequences of tephra layers and associated deposits, their distribution and stratigraphic relationships, and their relative and numerical ages. Involves defining, describing, characterizing, and dating tephra layers in the field and laboratory

Use of tephra layers as isochrons (time-parallel marker beds) to connect and synchronize sequences and to transfer relative or numerical ages to them using stratigraphy and other tools. An age-equivalent dating method

Tephrochronology All aspects of tephra studies and their application (sensu lato)

Tephrochronometry Obtaining a numerical age or date for a tephra layer

The term tephra applies to all volcanological grain sizes: ash (grains $<2 \mathrm{~mm}$ in diameter), lapillus or lapilli (2-64 mm), and blocks (angular) or bombs (subrounded) (>64 mm). Note that the volcanological grain-size scale, useful in tephra studies and arguably preferable to sedimentological grain-size units, is subdivided further into classes such as coarse ash, fine ash, etc (see White and Houghton, 2006). Lowe (2008a) provided further details about tephra-related 
terminology and the different ways in which the word 'tephra' can be used, especially in relation to volcanological terms. Although 'tephra' is feminine singular and hence in Greek is used as a collective noun with singular verb forms, appending 's' (thus 'tephras') is appropriate for pluralization in modern useage and to avoid ambiguity (Froggatt and Lowe, 1990; Ray Harlow pers. comm., 2007).

'Tephrochronology' in its original sense (sensu stricto) is the use of tephra layers as isochrons or time-parallel marker beds to connect or correlate sequences, and to transfer relative or numerical ages to such sequences where the tephras have been dated. Tephrochronology is not 'dating tephras'. Rather, 'tephrochronometry' is the term used to describe the dating of tephra layers either directly or indirectly. In recent times the term tephrochronology (sensu lato) has been used more broadly to describe all aspects of tephra studies (Lowe, 2008a). Specialists who study tephras are called tephrochronologists.

Undertaking tephrochronology always requires tephrostratigraphy. 'Tephrostratigraphy' is the study of sequences of tephras and associated deposits and their distribution and stratigraphic relationships (superpositions), and their relative and numerical ages. It involves defining, describing, and characterizing or fingerprinting tephra layers using their physical, mineralogical, or geochemical properties from field and laboratory-based observations or analyses. Strictly, obtaining a numerical age or calendrical date via tephrochronometry may also be considered part of tephrostratigraphy.

In the last two decades there has been a revolutionary development focussed on detecting diminutive, distal tephras that are not visible to the naked eye in the field and which are called cryptotephras. From the Greek word kryptein meaning 'to hide', cryptotephras (previously called 'microtephras') typically comprise fine or very fine to extremely fine ash-sized (usually < 125 $\mu \mathrm{m})$ concentrations of glass shards preserved in sediments including ice, or in soils (Lowe and Hunt, 2001; Alloway et al., 2007a; grain-size names from White and Houghton, 2006). In some 
cases, cryptotephras may comprise non-visible crystal concentrations instead of, or as well as, glass shards (Lowe et al., 2007; Matsu'ura et al., submitted for publication).

The letter 'o' rather than ' $a$ ' is the appropriate connecting letter in all these terms derived from tephra. The adjective 'volcanic' is redundant when referring to tephras because they are volcanic by definition. The term 'airfall' is no longer used (fallout tephra, tephra-fall, or ash-fall deposit if appropriate, are used instead).

Several other words have tephra or tephrós ('ash coloured') at their root but none is relevant to tephrochronological studies. For example, 'tephrite' refers to a typically ash-coloured alkalic basaltic volcanic rock erupted effusively as lava, not explosively. 'Tephroite' is a mineral in the olivine group $\left[\mathrm{Mn}_{2} \mathrm{SiO}_{4}\right]$ that is commonly ash-grey to olive or bluish green in colour. Finally, the word 'tephromancy' refers to divination by the inspection of sacrificial ashes, requiring supernatural insight to foresee the future. The use of layers of tephra or ash beds as records of past volcanic activity, together with suitable age models and other volcanological information, provides insight into possible future activity of a volcano (Section 4) - but the method is founded in stratigraphy, petrography, and geochronology, i.e., science, not supposed supernatural powers!

\section{Tephras as dossiers of volcanic eruption history}

As well as providing isochrons for palaeoenvironmental research, tephras provide a comprehensive record or dossier of explosive volcanism and recurrence rates in the Quaternary or earlier and can therefore be used to establish time-space relationships of volcanism and insight into petrogenesis (e.g., Kohn and Topping, 1978; Wilson and Hildreth, 1997; Nakagawa et al., 1999; Smith et al., 2002, 2005, 2006; Óladóttir et al., 2008; Turner et al., 2008b), and for volcanic hazard prediction and risk management (e.g., Shane and Hoverd, 2002; Hurst and Smith, 2004, 2010; Jenkins et al., 2007; Turner et al., 2008a, 2009; Lindsay et al., 2009). Tephra sequences 
preserved in peat or lake or marine sediments, or in ice, at medial or distal sites paradoxically may provide records potentially more comprehensive, or more assessable, than those proximal to volcanoes where the stratigraphy can be compromised by deep burial or erosion or other factors (Larsen et al., 1998; Alloway et al., 2005; Narcisi et al., 2005, 2010; Lowe et al., 2007; Allan et al., 2008; Paterne et al., 2008; Turner et al., 2008b; Davies et al., 2010b). Additionally, such medial to distal sequences (unlike many proximal sequences) may enable the stratigraphic interfingering and superpositioning of eruptives from multiple volcanic sources to be documented and interpreted (Lowe, 1988a; Lowe et al., 1999; Shane et al., 2002, 2006; Molloy et al., 2009; Kuehn and Negrini, 2010).

As an example of a comprehensive volcanic history established by tephrostratigraphy and volcanology, the ages and magma volumes of numerous tephra-generating volcanic eruptions of the Taupo and Okataina caldera volcanoes of the central Taupo Volcanic Zone, North Island, New Zealand, are listed stratigraphically in Fig. 2. A total of 63 eruptive episodes since ca. $61 \mathrm{ka}$ cal BP have been identified for these two volcanic centres which remain the two most productive and frequently erupting rhyolite (silica-rich) volcanoes on Earth (Wilson et al., 1995, 2009). Note that the eruptive volumes in cubic kilometres can be recorded either as 'dense rock equivalent' or as 'deposited material'. The latter may alternatively be referred to variously as 'bulk volume', 'material as erupted', or 'uncompacted tephra' (Smith et al., 2005; see also Mason et al., 2004). 

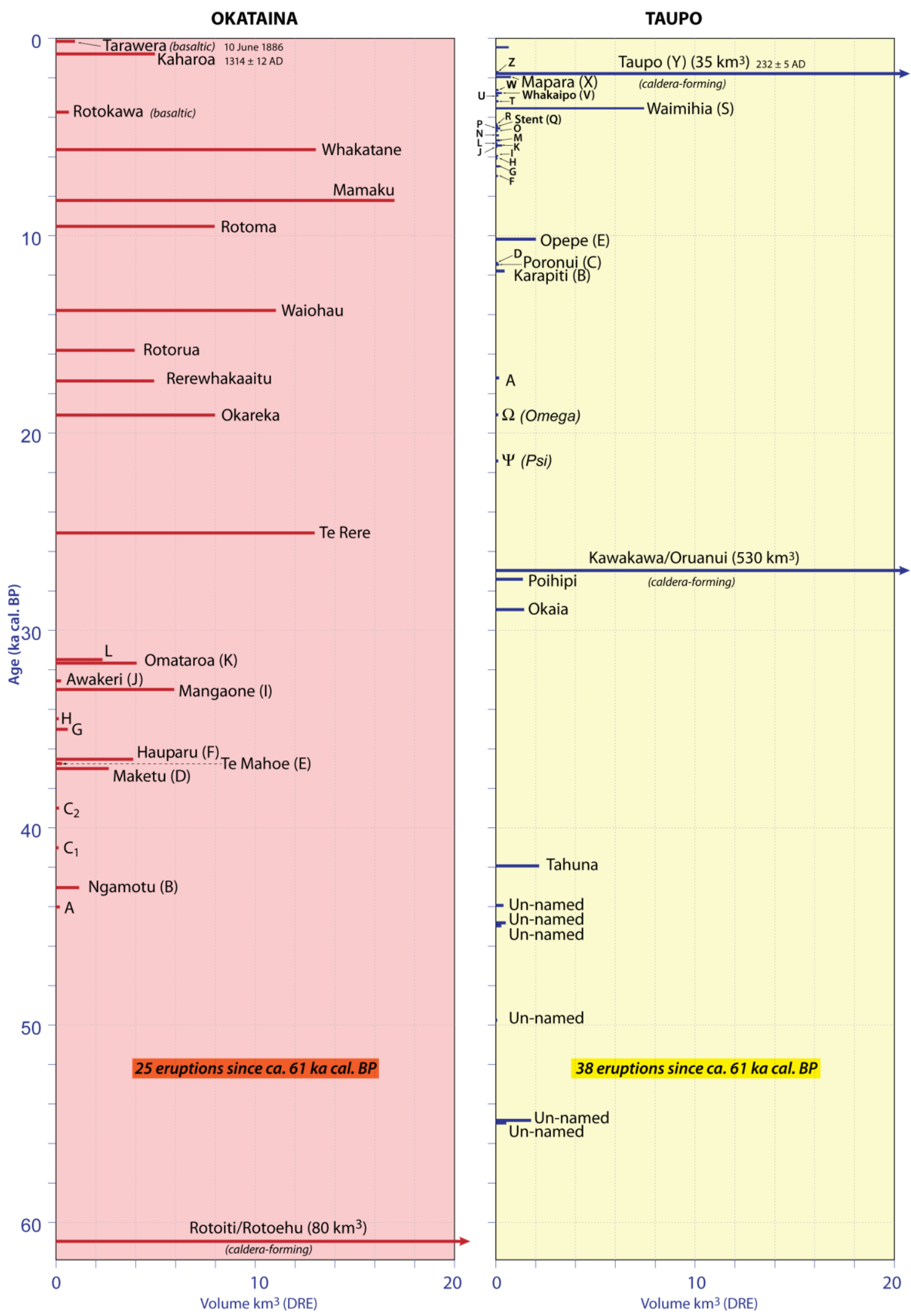

Fig. 2. Interfingering stratigraphic relationships, ages, and volumes (as non-vesiculated, void-free magma or dense-rock equivalent, DRE; multiply by $\sim 3$ to obtain approximate bulk volumes) of tephras erupted from Okataina and Taupo caldera volcanoes in North Island, New Zealand, since ca. $61 \mathrm{ka}$ cal BP (based on Wilson et al., 2009). Another significant unit (not depicted) is the rhyolitic Earthquake Flat tephra $\left(7 \mathrm{~km}^{3} \mathrm{DRE}\right)$, which was erupted from the Kapenga caldera volcano (adjacent to Okataina) immediately after the Rototiti/Rotoehu eruption. 


\section{Mapping and correlating tephras from metre to sub-millimetre scales}

\subsection{Correlation of tephras at a range of thickness scales (proximal to distal)}

In the field, tephra beds ranging in thickness from metres to centimetres are mapped effectively using so-called 'hand-over-hand' methods. In this processs, spatially-referenced sequences containing or comprising tephra layers are traced from outcrop to outcrop, commonly from proximal to distal regions, using their stratigraphic relationships and salient physical properties including colour and bedding characteristics, or features such as pumice density or colour, the presence of accretionary lapilli, or distinctive phenocrysts in pumices, or free crystals, such as biotite or hornblende visible in the field via a hand lens (examples of these minerals are shown in Section 6.3). As noted earlier, stratigraphically associated palaeoenvironmental and palaeoecological information, such as an interstadial pollen assemblage, or the presence of plant macrofossils that indicate the season of deposition, or archaeological associations, may also help establish correlation (e.g., Kohn et al., 1992; Feibel, 1999; Shane and Sandiford, 2003; Froese et al., 2006; Lowe et al., 2010; Reyes et al., 2010).

Typically, tephra-fall beds tend to evenly mantle or drape the pre-existing topography like blankets or snow (Fig. 3). Using a multi-coring approach together with ground-penetrating radar to elucidate in detail the stratigraphy and spatial distribution of multiple late Quaternary tephras in sediments in a small lake basin in northern New Zealand, Green and Lowe (1985) and Lowe (1985) showed that the thin, distal tephra layers, interspersed with organic sediment, had each been deposited as a spatially continuous mantling deposit that mimicked the concave shape of the basin's morphometry. 


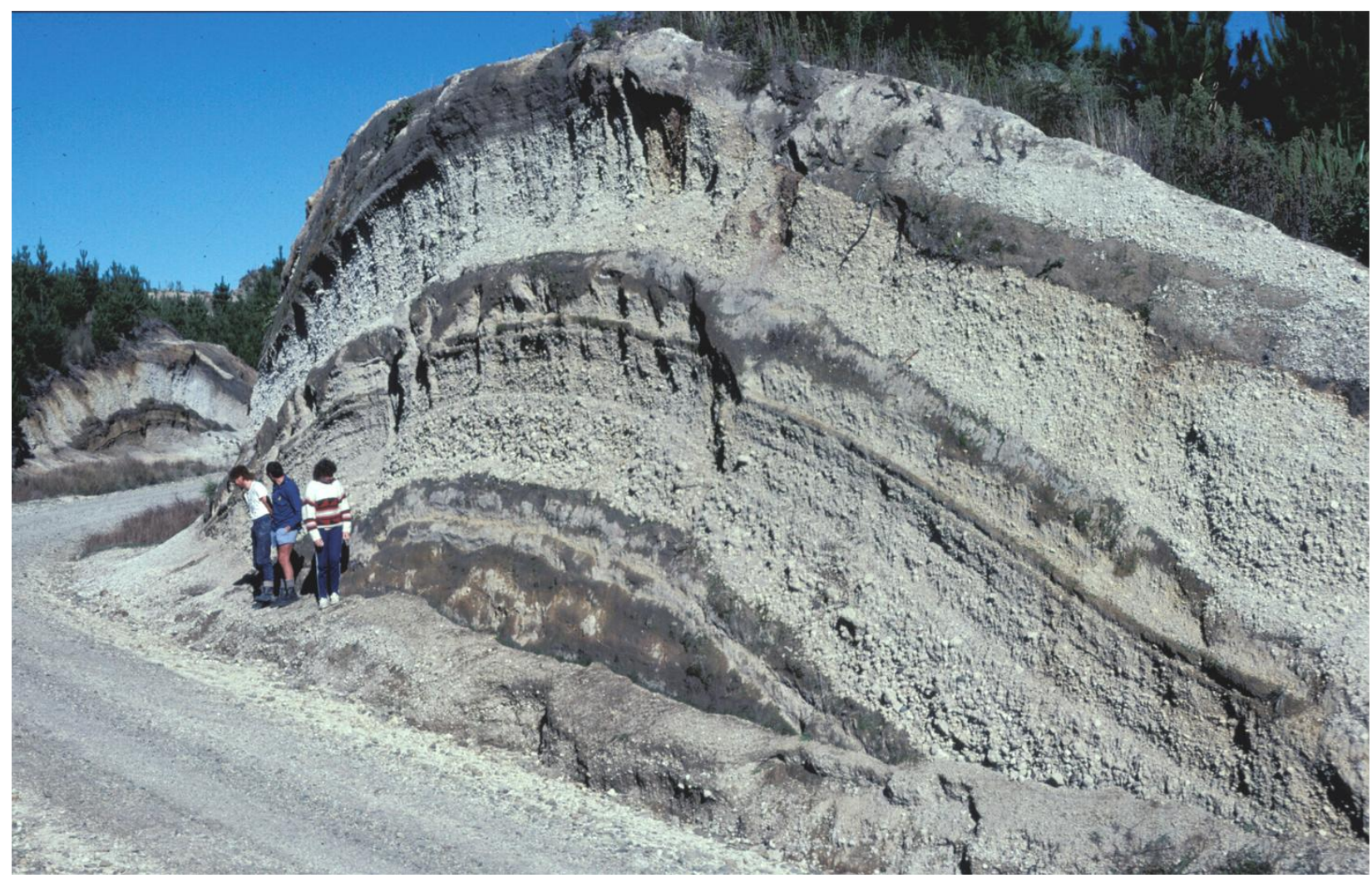

Fig. 3. Metre-thick, proximal, coarse, partly bedded pumiceous late Holocene rhyolitic tephra beds (comprising mainly blocks/bombs and lapilli) and associated darker buried soil horizons (marking volcanic quiescence) evenly draping an antecedent strongly-rolling landscape near Taupo, central North Island, New Zealand. Photo: D.J. Lowe

Prominent thick beds, or beds with distinctive features that contrast with those of adjacent deposits, provide key reference horizons - marker beds - within a sequence (Fig. 4). The nature of buried soil horizons or loess or other deposits associated with tephra layers provide additional information useful for correlation. Proximal deposits usually contain large grains and a greater range of components, such as heavier lithics and loose crystals, than distal deposits downwind, which tend to be dominated by lighter pumice fragments and glass shards (e.g., Sarna-Wojcicki et al., 1981b). Distal tephras are always fine-grained in comparison with proximal fall deposits. Tephra layers normally become thinner away from source, usually but not always exponentially (Houghton et al., 2000), and tend to lose diagnostic features, or become weathered or mixed together by soil-forming processes or bioturbation or cryoturbation. Consequently, tracing them subaerially is ultimately limited generally to deposits that are of the order of centimetres in thickness (Lowe, 1988a). However, tephra layers may be preserved in frozen sediments including 
ice-rich loess or 'mucks', or ice wedges, in high latitudes such as in Alaska or the Yukon

Territory of Canada, although they may be distorted, dislocated into lenses and pods, or mixed to some extent by periglacial processes (Fig. 5; Sanborne et al., 2006; Froese et al., 2009).

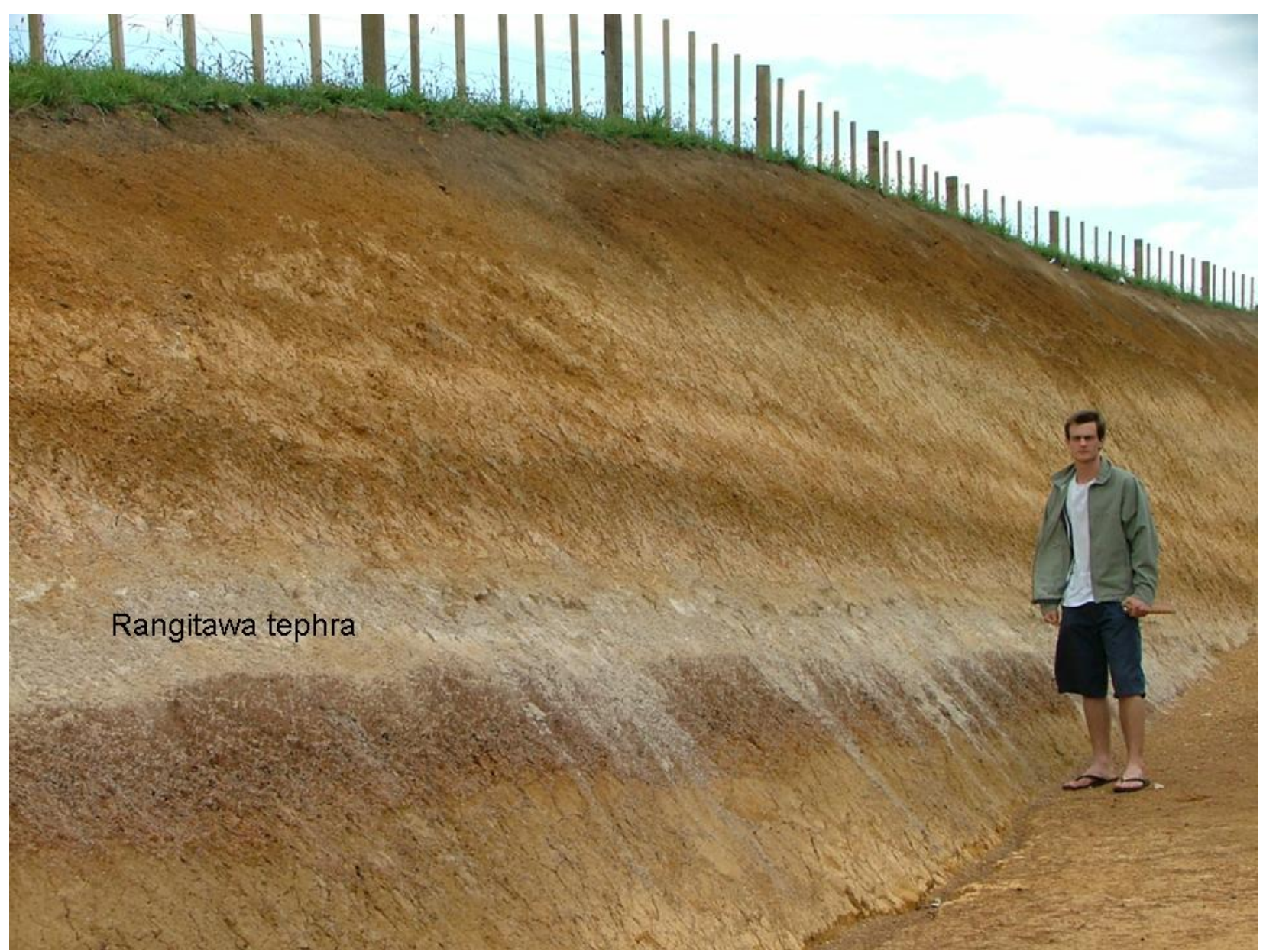

Fig. 4. Examples of stratigraphic marker beds.

A. Prominent white rhyolitic Rangitawa tephra (ca. $340 \mathrm{ka}$ ) within a sequence of stronglyweathered tephra beds and associated buried soils near Hamilton, North Island, New Zealand. Rangitawa tephra contains characteristic coarse-ash (sand)-sized golden platy crystals (biotitekaolinite intergrade) and coarse-ash-sized quartz crystals. This very widespread tephra, erupted near the end of MOI stage 10 and dated by a wide array of methods (see text), overlies unconformably a dark reddish-brown buried soil older than ca. $0.78 \mathrm{Ma}$. 


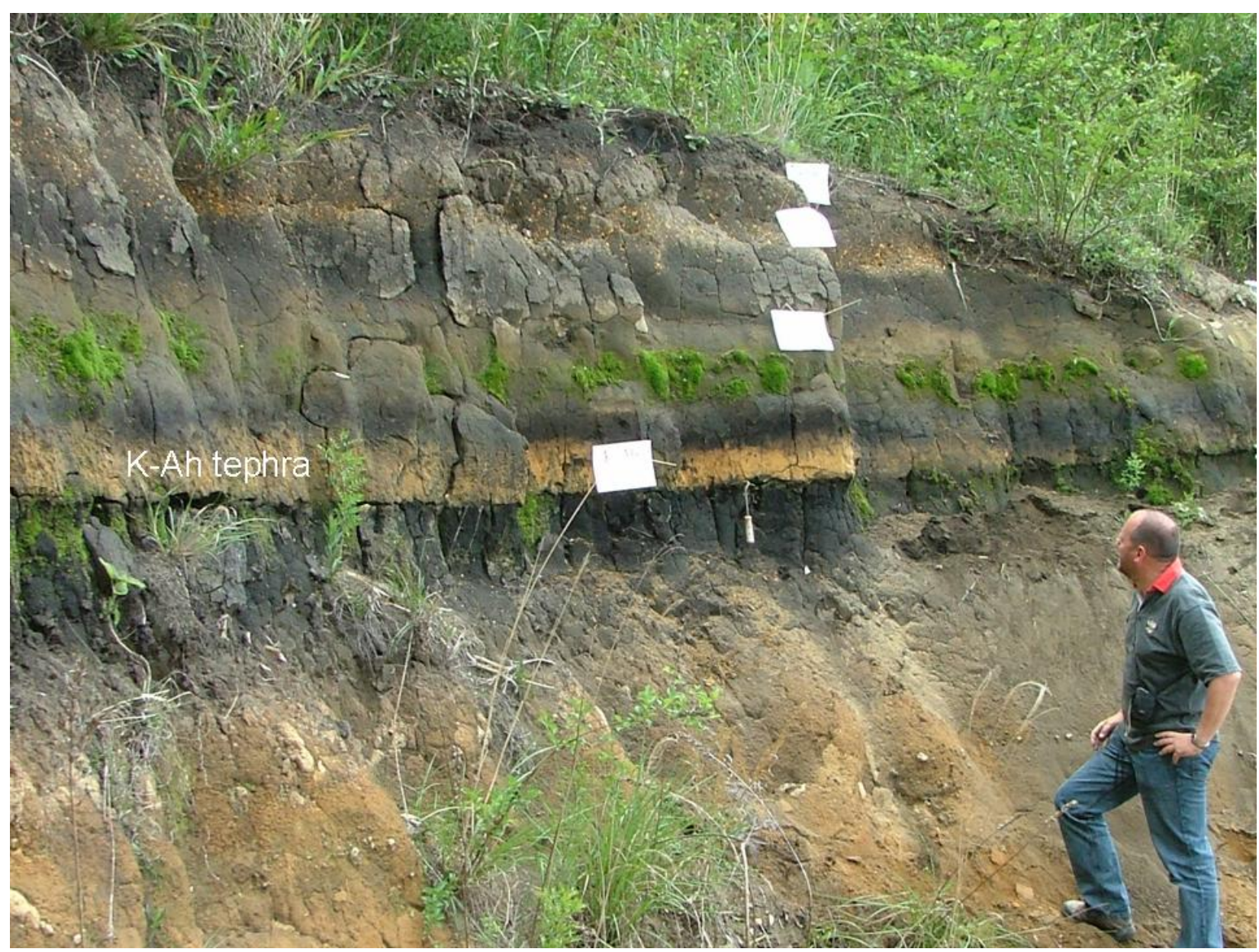

B. Distinct bright yellowish-orange Kikai-Akahoya (K-Ah) tephra (ca. 7.3 ka cal BP) sandwiched between buried black soil horizons at Sen-ninzuka, northeastern Kyushu Island, Japan. Cutting tool (at base of K-Ah) is $\sim 30 \mathrm{~cm}$ long. This tephra, a rhyolitic-dacitic co-ignimbrite ash erupted from (now submerged) Kikai caldera $\sim 50 \mathrm{~km}$ south of Kyushu, is widespread over much of Japan and adjoining seas and on the southern Korean Peninsula (Machida, 2010). It is an especially important chronostratigraphic marker for the chronology of the Jomon culture including changes in pottery types and ceramics (Moriwaki et al., 2010a). Photos: D.J. Lowe 


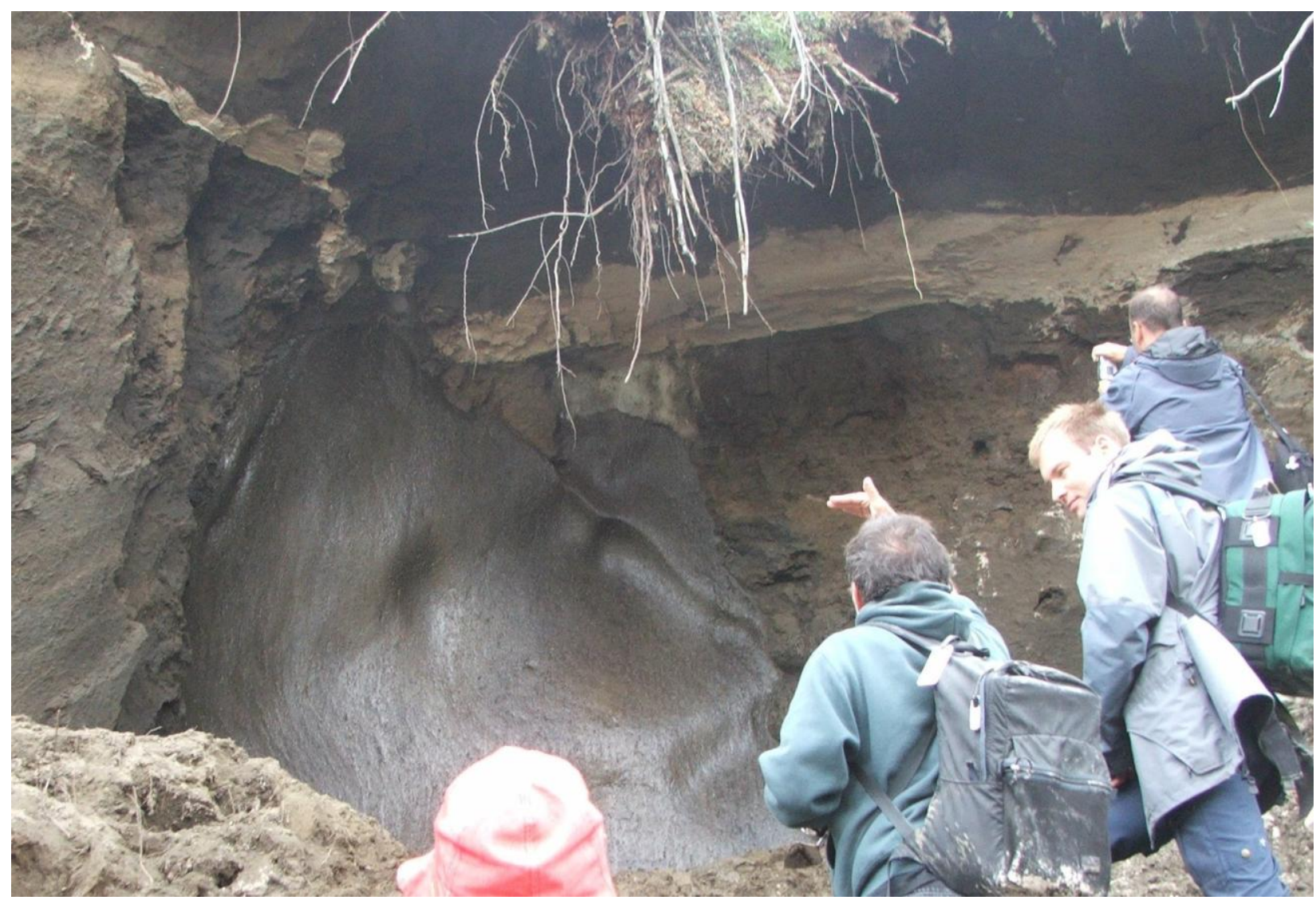

Fig. 5. Dawson tephra, aged ca. $30 \mathrm{ka}$ cal BP, in frozen loessial 'muck' overlying a syngenetic ice wedge at Quartz Creek near Dawson City, Yukon Territory. The tephra, essentially unweathered, comprises mainly very fine ash (Sanborne et al., 2006). Depression of tephra into the wedge-top marks the former depression of a polygonal ground network, indicating the ice wedge was active when the tephra was deposited probably in late winter or early spring (Froese et al., 2006, 2009). The tephra, up to $\sim 40 \mathrm{~cm}$ thick and overthickened, has been dated by ${ }^{14} \mathrm{C}$ on plant macrofossils and optically stimulated luminescence dating (Demuro et al., 2008) and marks the onset of MOI stage 2 in central Yukon. It derives probably from Emmons caldera in the Aleutian arc-Alaska Peninsula region of southwestern Alaska (Froese et al., 2009). Photo: D.J. Lowe

Similarly, cores taken from lake sediments and peat bogs at distal sites potentially provide a high-resolution record of visible tephra layers that range typically from centimetres to only millimetres in thickness (Fig. 6). Uncommonly, sections of peat containing tephras may be exposed, such as at Kaipo bog in northern New Zealand (Lowe et al., 1999; Hadjas et al., 2006). Such cores (or sections) thus complement the dry-land records and enable tephra distribution patterns, usually shown as isopachs, which are lines depicting deposits of equal thickness, to be mapped with improved accuracy over much greater distances than previously attainable (Fig. 7) (Lowe, 1988b; Rodbell et al., 2002; Shane et al., 2002; de Fontaine et al., 2007). Tephras preserved in marine sediments also provide an enhanced record of their distal distribution (e.g., 
Froggatt et al., 1986; Carey, 1997; Lacasse et al., 1998; Shane et al., 2006), although thicknesses may not directly reflect an eruptive signal, and the distinction between 'primary' tephra layers, deposited in a single continuous event from ash fallout onto the sea surface (thence to be delivered to the sea bed) and 'secondary' deposits from syndepositional turbidity currents developed by slumping of previously deposited ash, may not be attainable (Manville and Wilson, 2004). Layers thinner than a few centimetres may not be preserved as such because of bioturbation, instead becoming dislocated into lenses or into zones of dispersed glass (Manville and Wilson, 2004; Wetzel, 2009).

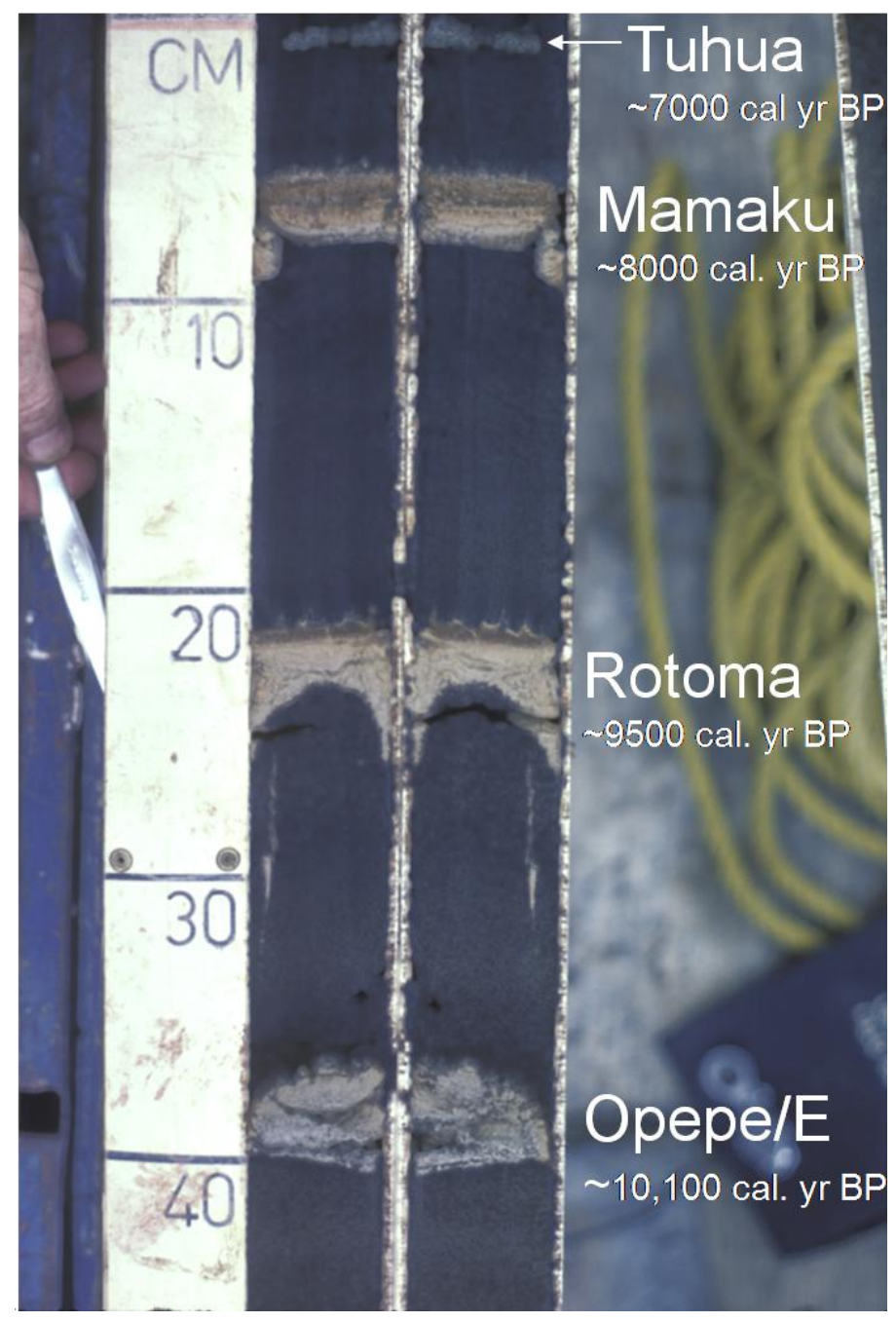

Fig. 6. Part of a longitudinally sliced core from Lake Rotongata near Hamilton, North Island, New Zealand, showing four distal, centimetre-thick, rhyolitic Holocene tephra layers of coarse to very fine ash grades derived from three different sources (Tuhua: Mayor Island/Tuhua volcano; Mamaku and Rotoma: Okataina volcano; Opepe/E: Taupo volcano). The layers are preserved within dark, fine-grained organic lake sediment. Scale marks are $10 \mathrm{~cm}$ apart. Photo: D.J. Lowe 


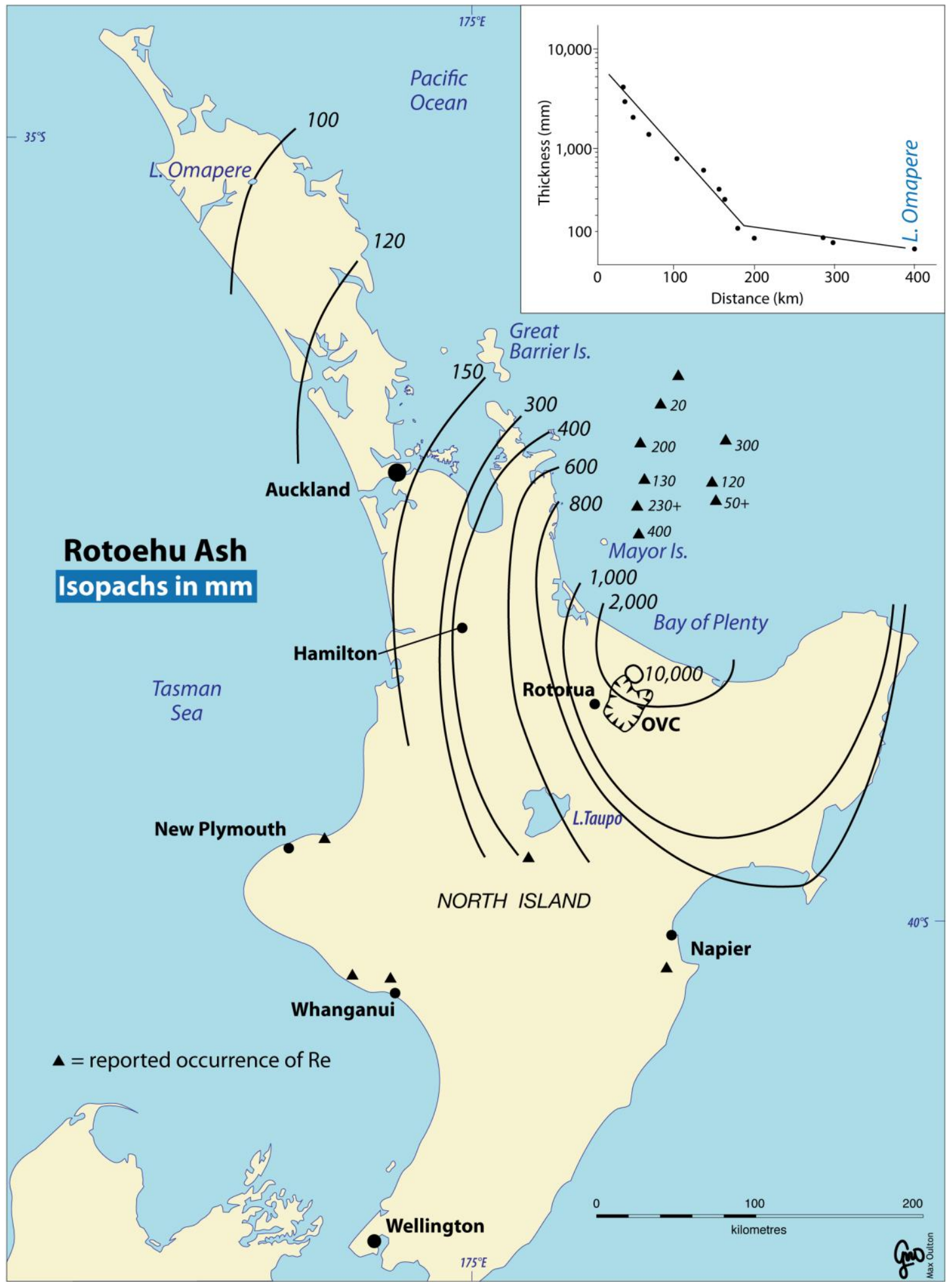

Fig. 7. Isopach map in millimetres of Rotoehu Ash, North Island, New Zealand, and other occurrences marked by triangles (some as crytotephras) but with uncertain or unknown thickness. Rotoehu Ash was erupted ca. 61 ka from the northern Okataina Volcanic Centre (OVC). Inset shows log-normal plot of isopach thickness against distance from source, showing thinning. Break in slope marks a change in dispersal mechanism during the plinian phase of the eruption, or possibly tephra fallout from co-ignimbrite ash (after Newnham et al., 2004, with addition of marine-core data from Shane et al., 2006). Note that marine isopach thicknesses may be compromised by depositional processes (see Manville and Wilson, 2004). 


\subsection{Isopach versus isomass maps}

One problem with using tephras in cores for constructing isopachs is that of possible compaction and dissemination, meaning that layer thicknesses are effectively underestimated. Lowe (1988b) used bulk density estimates (following Borchardt et al., 1973) to generate a thickness correction factor for tephra distribution studies in northern New Zealand on the basis of lake sediment occurrences. Such a fundamental parameter as tephra thickness can be difficult to measure 'accurately' both in sediment cores and subaerially (e.g., see Sarna-Wojcicki et al., 1981a; Manville and Wilson, 2004). Cryptotephra glass-shard or crystal occurrences are particularly problematic in this regard: estimates of erupted volumes, for example, do not include cryptotephra occurrences in calculations because of great variability spatially in glass-shard or crystal concentrations and uncertainty about how these variations should be interpreted (e.g., see Davies et al., 2010a). The use of isomass maps, whereby thickness units are replaced by mass per unit area (e.g., $\mathrm{g} / \mathrm{cm}^{2}$ or $\mathrm{kg} / \mathrm{m}^{2}$ ), may provide a way around this sort of uncertainty because they can account for compaction of the deposits and for variation of deposit density with distance from the vent (Bonadonna, 2006). As a result, in addition to the classic field parameters including thickness, observations should ideally also include deposit density, particle density, and tephra (or cryptotephra) accumulation per unit area (Bonadonna, 2006; see also Mason et al., 2004). Recently, Pyne-O'Donnell (in press) constructed novel and highly effective maps of glass-shard concentrations (expressed as shards per cubic centimetre) for several cryptotephras, and a visible tephra, for two lakes in Scotland.

\subsection{Cryptotephras}

Cryptotephra studies on peats or lake, marine, or aeolian sediments, and ice cores, have been undertaken now in more than 24 countries (Lowe, 2008a). Analyses of cores from alpine ice 
caps such as Lomononsovfonna on Spitsbergen Island, Svalbard (Kekonen et al., 2005;

Wastegård and Davies, 2009), and Quelccaya in the Peruvian Andes (Thouret et al., 2002) have been employed as well as those from the Greenland and Antarctic polar ice sheets (e.g., Zielinksi et al., 1994; Cole-Dai et al., 2009). These remarkable wide-ranging studies have provided cryptotephra fallout distribution patterns to the sub-millimetre scale at distances of hundreds to several thousands of kilometres from source, greatly extending known geographical limits (e.g., van den Bogaard and Schminke, 2002; Dunbar et al., 2003; Blockley et al., 2007a; Lowe et al., 2007; Davies et al., 2008, 2010b; Hillenbrand et al., 2008; Payne et al., 2008; Coulter et al., 2009).

In considering the fallout distribution patterns of cryptotephras, it is relevant to record firstly that historic and modern volcanic ash clouds, as reported by observers, very commonly are blown distances ranging from $\sim 750 \mathrm{~km}$ to $\sim 2500$ km (e.g., Volcán Huaynaputina, 1600 AD; Mt Tarawera, 1886; Mt St Helens, 1980; Mt Pinatubo, 1991). Further, ash from the Hekla eruption in Iceland in 1947 reached Finland, 3800 km from source (Walker, 1981), and that from the eruptions of Mt Spurr (1992) and Klyuchevskoy (1994) (Miller and Casadevall, 2000) travelled at least $\sim 5000 \mathrm{~km}$. Most recently, tephra from the Icelandic Eyjafjöll eruptions of April-May 2010 was distributed over much of Scandinavia and Europe and as far as northern Russia (Siberia), more than $\sim 8,000 \mathrm{~km}$ from source (Davies et al., 2010a). Thus the occurrence of cryptotephra deposits over such large distances might seem predictable provided that shard (or crystal) fallout is preserved and the concentrations are sufficient to be detected using appropriate methods.

Such predictions generally have been borne out. For example, glass shards from the 1982 El Chichón eruption (Mexico) were identified in Greenland snow, 10,000 km from the volcano (Zielinksi et al., 1997), and shards from the 1600 AD Huaynaputina eruption (Peru), and from the 1883 Krakatau and 1963 Agung eruptions (Indonesia), were identified in Antarctic ice cores 12,000 km from volcanic source (de Silva and Zielinski, 1998; Laluraj et al., 2009). Hemispheric and inter-hemispheric transport of fine glass shards $(<5 \mu \mathrm{m}$ in diameter $)$ was earlier 
reported by Palais et al. (1990, 1992). In some cases, however, expected occurrences of cryptotephras may not be found, one reason possibly being inadequate methodologies as described by Stanton et al. (in press). Further, Davies et al. (2010a) emphasised that the scattering and patchiness of fallout from distal plumes, partly because of variable weather conditions, provided further constraints on the likelihood of recovering glass shards from any particular location (visible or cryptic). Pyne-O’Donnell (in press) pointed out also that numerous additional variables were important, especially the seasonal factors at the time of deposition including the presence or absence of ice cover, atmospheric wind strength, regional synoptic conditions, and local rainfall. Intense, highly localized precipitation through an ash-bearing air mass would also deposit far more ash into a catchment by wash-out than would result from dry-air deposition alone, as shown by the Hekla 1947 eruption, when precipitation throughout southern Finland resulted in some of the heaviest and most localized deposition of ash along the eruption plume route (Pyne-O'Donnell, in press). Similarly, rain-flushing through co-ignimbrite ash clouds was invoked by Kobayashi et al. (2005) to explain an occurrence of overthickened tephra beds in northern New Zealand. Pyne-O'Donnell (in press) noted that each factor additionally would be modulated by the general longer-term climatic regime (e.g., stadial versus interstadial).

Techniques used to detect and map cryptotephras or thin, visible tephras include field or ship-board instruments such as core scanners and magnetic susceptibility meters (e.g., Vogel et al., 2009; Brendryen et al., 2010; Peters et al., 2010). Some techniques are destructive, others are not (Gehrels et al., 2008). They include ground penetrating radar (Lowe, 1985), magnetic susceptibility and remanent magnetisation (Hodgson et al., 1998; Takemura et al., 2000; Carter et al., 2002; Rasmussen et al., 2003; de Fontaine et al., 2007; Gomez et al., 2007; Venuti and Verosub, 2010), X-radiography (Lowe, 1988b; Dugmore and Newton, 1992; Turner et al., 2008b; Marshall et al., 2010), X-ray fluorescence (XRF) (Hogg and McCraw, 1983; Gehrels et al., 2008) including XRF-based core scanning (Vogel et al., 2009; Révillon et al., 2010), and scanning Xray analytical microscopy (Katsuta et al., 2007). Further techniques include spectrophotometry 
(reflectance, luminescence) (Caseldine et al., 1999; Gehrels et al., 2008), high-resolution micropetrography (de Vleeschouwer et al., 2008), high-resolution trace-element analysis by instrumental neutron activation analysis (INAA) (Lim et al., 2008), and measurements of particle size distribution, total organic carbon, and loss-on-ignition (Gehrels et al., 2006, 2008; Payne and Gehrels, 2010; Pyne-O’Donnell, in press).

A technique central to most cryptoephra studies is the enumeration of glass-shard concentrations (e.g., van den Bogaard et al., 1994; Dugmore et al., 1995; Hall and Pilcher, 2002; Turney et al., 2004; Gehrels et al., 2006; Kristjánsdóttir et al., 2007; Peters et al., 2010; PyneO'Donnell, in press). Such counting of shards (or crystals) requires the use of concentration techniques including ashing (burning) or step-wise acid or alkali digestion to remove enclosing organic matter such as by $\mathrm{NaOH}$ treatment (e.g., Rose et al., 1996; Hall and Pilcher, 2002), density separation by flotation to separate material (usually $<2.5 \mathrm{~g} \mathrm{~cm}^{-3}$ unless basaltic) (Turney, 1998), or magnetic separation (e.g., Froggatt and Gosson, 1982; Mackie et al., 2002; PyneO'Donnell, in press). Matsu'ura et al. (submitted for publication) used the occurrence of a tephra-derived heavy mineral, cummingtonite, preserved within loess deposits in Japan, to detect the presence of cryptotephras where associated glass shards had likely been dissolved. Vogel et al. (2009) used both magnetic susceptibility and XRF-based core scanning to identify six cryptotephras in lake sediments, the glass-shard concentrations being characterized by peaks in $\mathrm{K}$, Zr, and Sr. Andrews et al. (2006) used X-ray diffractograms of $<2 \mathrm{~mm}$-size fractions obtained from marine sediments in cores east of Greenland and near Iceland to detect peaks in volcanic glass concentrations (as weight \%) even where discrete tephra layers were not visible - i.e., the presence of cryptotephras in the cores was able to be shown relatively rapidly, enabling closer sampling and further geochemical analysis of glass shards to be undertaken to affect correlation. An efficient core sampling method that used a contiguous sampling device to take sediment slices was described by Pyne-O’Donnell (in press). 
Generally, glass shards in cryptotephra deposits are fine grained, typically $<\sim 100-125 \mu \mathrm{m}$ in diameter as noted earlier, and grains $\sim 40 \mu \mathrm{m}$ or smaller are not uncommon depending on location and source (e.g., deMenocal and Brown, 1999; Lim et al., 2008). The vertical spread of cryptotephra components in a deposit can be markedly variable, ranging from many centimetres (or even decimetres) to only a few centimetres or millimetres (or less) in thickness depending in part on the type of depositional environment. For example, glass shards comprising the distal, non-visible Vedde Ash are stratigraphically constrained to within about $1 \mathrm{~cm}$ in varved lake sediments in central Europe but extend well beyond such a discrete thickness in less stable lake sediments elsewhere (Blockley et al., 2007a; Pyne-O’Donnell, in press). Reworking and dissemination of tephras or cryptotephras are discussed further below in Section 5.4.

In ice cores, glass shards may be quite variable in size (depending on distance from source and other factors), and typically sparse although not always. The largest shards in the NGRIP core between ca. 26 and $42 \mathrm{ka}$ cal BP were recorded by Davies et al. (2010b) as $\sim 80-100 \mu \mathrm{m}$, and the smallest were $\sim 10-30 \mu \mathrm{m}$. Commonly, grains in ice cores may be only 5-15 $\mu \mathrm{m}$ in diameter, sometimes as small as $3 \mu \mathrm{m}$ (Kuehn and Froese, 2010), in Greenland, Antarctica, or elsewhere (e.g., Mt Logan, Canada), and these small sizes pose challenges for geochemical analysis (Davies et al., 2004b; Kurbatov et al., 2006; Kuehn and Froese, 2010; discussed further below in Section 6). A new finding from recent ice-core work in Greenland has been that the use of sulphate horizons or electrical conductivity measurements (ECMs) as proxies for identifying cryptotephra horizons (volcanic events) may not always be valid (Mortensen et al., 2005; Davies et al., 2008, 2010b). For example, glass shards representing the Icelandic basaltic tephras FMAZ II and FMAZ III do not coincide with distinct sulphate or ECM signals in the NGRIP ice core (Davies et al., 2010b). Consequently the ice-core-based tephra records constructed thus far are likely to be incomplete, and more cryptotephras may now be detectable by sampling ice layers without attendant sulphate signals. 
Glass-shard concentrations may be recorded as the number of shards counted (using a polarizing microscope and point counter) in either a set volume of wet sediment (usually $1 \mathrm{~cm}^{3}$ ), or in a gram or milligram of dry sediment, hence resulting in units of shards per gram (or milligram) dry weight (e.g., Gehrels et al., 2006; Wastegård and Davies, 2009; Payne and Gehrels, 2010; Peters et al., 2010), or shards per cubic centimetre (Pyne-O’Donnell, in press). Matsu'ura et al. (submitted for publication) reported concentrations as shards per 3000 grains. Gehrels et al. (2006), working in peat deposits in northern North Island, New Zealand, adapted a palynological quantifaction method whereby glass shards were recorded and counted alongside Lycopodium spores added to the sample. Replicate counts of selected slides indicated that the number of shards counted for 100 Lycopodium spores was adequately representative of the sample. Glass shard concentrations were reported as shards per milligram dry weight calculated using the formula:

$$
c=l \times a / b d
$$

where $a$ is glass shard count, $b$ is Lycopodium spore count, $d$ is sample dry weight in milligrams, and $l$ is the number of Lycopodium spores in the tablet added to the sample (Gehrels et al., 2006). Grain counts in different size fractions (e.g., 63-125 $\mu \mathrm{m}$ and 125-150 $\mu \mathrm{m}$ ) may provide additional useful information regarding provenance, as noted below (Brendryen et al., 2010).

Even extremely diffuse or sparse concentrations of glass are important not only for cryptotephrostratigraphy but also from a volcanic hazard viewpoint. For example, the impact of very sparse cryptotephras was highlighted locally by disruptions in the aviation industry in New Zealand during the 1995-1996 eruptions of Mt Ruapehu (Newnham et al., 1999a), and more extensive disruptions across much of Europe took place during the 2010 eruptions of Eyjafjöll (Davies et al., 2010a). Newnham et al. (2010) showed that diffuse fine ash (as cryptotephra) poses a risk to respiratory health at greater distances from an eruption than currently perceived. 
They identified an increase in respiratory-related mortality in Auckland and Hamilton in northern New Zealand as a possible consequence of the effects of diffuse, fine-grained cryptotephra fallout at these locations, which had been barely or not observed, from the 1996 Mt Ruapehu eruption. The hazard arises because the finest 'respirable' fraction of erupted tephra with potentially hazardous physico-chemical properties is likely to be ejected highest into the atmosphere and dispersed the greatest distance. At such locations where diffuse ashfall is barely or not visibly discernible, indviduals therefore do not perceive any risk and hence preventative measures (e.g., use of face masks) seemingly can be ignored despite those suffering from poor respiratory health being at considerable risk (Newnham et al., 2010). A similar conclusion relating to possible health impacts (especially respiratory) from distal fallout of the widespread ca. $12.9 \mathrm{ka}$ cal BP Laacher See tephra on people (possibly also game animals) in Europe or Scandinavia was inferred by Riede and Bazely (2009).

\subsection{Reworking of tephras and taphonomic considerations}

One potential difficulty in tephra mapping or correlation is the possibility of tephra reworking or the dissemination or dispersion of glass shards or crystals. Reworked or disseminated tephras form diachronous rather than isochronous surfaces and hence their use tephrochronologically is fundamentally compromised unless reworking is very localised and near-contemporaneous with the primary depositional event (Fisher and Schminke, 1984; Lowe, 1988b; Shane et al., 1998; Boygle, 1999). The non-reworked part of a tephra deposit provides an isochron of maximum age (the date of the tephra eruption and primary deposition) but any reworked components are always younger. Where the date and extent of reworking are known accurately, then the reworked tephric materials may, however, provide a viable secondary isochron. 
Changes in tephra thicknesses that do not conform to normal spatial distribution patterns provide evidence that local reworking by wind, water/ice, or gravity has possibly taken place. For instance, as noted earlier, tephra-fall deposits tend to thin exponentially away from source and hence variation to such patterns may indicate that reworking has occurred (e.g., inset in Fig. 7). In New Zealand, anomalous thicknesses associated with tephra distribution patterns in sequences of last-glacial age led to the recognition of tephric loess overlying primary tephras (Vucetich and Pullar, 1969). An aeolian origin for such material both in New Zealand and elsewhere has been supported subsequently by grain-size, mineralogical, and quartz isotopic analyses (e.g., Benny et al., 1988; Mizota et al., 1990; Alloway et al., 1992; Yoshinga et al., 1992). Rain flushing through ash clouds may also lead to locally-overthickened tephra deposits (e.g., Kobayashi et al., 2005). In another example from California, only the basal, 1-m-thick part of a total tephra thickness of ca. $10 \mathrm{~m}$ represents primary fallout of the ca. $760 \mathrm{ka}$ Bishop Tuff eruptives in Owens Lake (Sarna-Wojcicki et al., 1997). The bulk of the deposits instead represent repeated episodes of reworking and redeposition of the tephra within the lake drainage basin by wind and runoff, probably quite rapidly (over several hundred to several thousand years). Above the basal primary tephra layer, the 'pure' tephra content progressively decreases through dilution as detrital material increases (Sarna-Wojcicki et al., 1997).

Anomalous grain-size patterns may also indicate reworking. For example, coarse glass shards in marine sediments in MD95-2006 from the northeastern Atlantic Ocean, although deposited initially as ash-fall, were likely transported to the core site by sea-ice rafting (Austin et al., 2004). A similar conclusion was reached from a study of tephras in sediments in the Southern Ocean, namely that relatively coarse grain sizes were indicative of emplacement by ice rafting (Shane and Froggatt, 1992). In the Norwegian Sea, iceberg rafting of numerous Icelandic or Jan Mayen-derived tephras, detected by counting and analysing glass shards together with lithics representing ice-rafted detritus in $63-125 \mu \mathrm{m}$ and $125-150 \mu \mathrm{m}$ grain-size populations in each deposit, was considered by Brendryen et al. (2010) to be responsible for a centennial- to 
millennial-scale time lag between the volcanic eruption events and the subsequent deposition of associated tephra in deep-sea sediments.

As well as being reworked in places by currents or slumping, marine tephras, especially thin deposits, may also be subject to bioturbation. Manville and Wilson (2004) observed that deep-sea tephras typically comprise glass-shard-dominated layers generally a few centimetres to tens of centimetres in thickness, usually with sharp bases but gradational (bioturbated) upper contacts. They noted that although continuous deep-sea tephra layers $<1 \mathrm{~cm}$ thick are rare, their presence formerly as contiguous layers is able to be inferred from discontinuous lenses and burrow infillings or disseminated tephric material (e.g., Kennett, 1981; Lacasse et al., 1998). From electron probe microanalyses of glass from such lenses in a study of marine cores near Japan, Hunt and Najman (2003) confirmed that adjacent lenses were indeed derived from the same (original depositional) layer. Such evidence indicates that sub-centimetre layers are generally insufficiently thick to suppress benthic biota and therefore to prevent post-depositional biomixing (Manville and Wilson, 2004). Wetzel (2009), however, showed that ash layers $\sim 1-4$ $\mathrm{cm}$ thick, as well as being subject to bioturbation, can also be preserved by rapid burial depending on environmental conditions. In a study of marine cores from the Caribbean Sea, Peters et al. (2000) suggested that zones of disseminated ash either reflected periods of terrestrial uplift and erosion, or deposition from small-scale eruptions that were insufficiently voluminous to deposit a visible layer (following Sigurdsson et al., 1980).

In Sweden, patchy tephra distribution patterns in peat deposits were attributed to postdepositional processes associated with fallout on snow cover, including redeposition by wind and meltwater (Bergman et al., 2004). Snow entrapment, wherein cold conditions with little or no summer melt cause a significant lag between the initial deposition of ash and its subsequent deposition into a lake, was identified by Davies et al. (2007) and Pyne-O’Donnell (in press) as another factor that could lead to an incorrect interpretation of the true position of the tephrostratigraphic isochron in lake sediments in some cold terrains. In the central Yukon 
Territory, the extraordinary thickness of Dawson tephra (Fig. 5) likely reflects reworking of a late winter-deposited tephra by snow melt in the spring following the eruption, indicating that the primary thickness (probably around $15 \mathrm{~cm}$ or less) is overestimated at valley-bottom sites (Froese et al., 2006).

The migration and hence vertical spread (dissemination) of shards over distances of some centimetres (up to $\sim 80 \mathrm{~cm}$ in extreme cases: e.g., Anderson et al., 1984) through soft sediments, including lacustrine, peat, or marine deposits, can also occur, leading to the stratigraphic difficulty of identifying the exact point in the sediments where tephra layer was deposited at the time of its eruption (Anderson et al., 1984; Beierle and Bond, 2002; Enache and Cumming, 2006; Gehrels et al., 2006; Wastegård et al., 2006; Brendryen et al., 2010; Pyne-O’Donnell, in press). In studies on Lake Svinavatn in Iceland, Thompson et al. (1986) for example showed that the upward spread of (sparse) ash grains (presumably mainly glass shards) in the sediments, identified by a neutron activation-determined chemical signature in the sediments that attenuated upwards, was the result of erosion of the primary tephra-fallout deposits in catchments for some decades following their initial deposition. Pyne-O'Donnell (in press) showed in Scotland that lacustrine reworking processes affected the taphonomy of rhyolitic and basaltic glass shards to different degrees, with the implication that distributions of rhyolitic and basaltic ash in lake sequences may require different interpretations when defining isochron stratigraphic positions. He was able to define the Vedde Ash isochron at the point of maximum rhyolitic shard counts whereas defining the isochron for the associated basaltic shards was at the point of their first occurrence.

Such dissemination and other 'taphonomic' problems evident in cryptotephra studies in particular clearly are important issues (Payne et al., 2005; Davies et al., 2007; Newton et al., 2007; Gehrels et al., 2008; Payne and Gehrels, 2010). As noted earlier, the environment of deposition helps govern the degree of dissemination of a specific distal tephra layer or cryptotephra concentration zone, with some deposits being substantially disseminated at some 
sites but tightly constrained stratigraphically as thin, discrete layers/concentration zones at others, such as Vedde Ash in varved lake sediments (Blockley et al., 2007a) and cryptotephra horizons in NGRIP (Davies et al., 2010b).

In Alaska, de Fontaine et al. (2007) showed that a range of factors including physiography and limnological and sedimentological conditions dictated the potential for markedly different tephra preservation records in lakes only $40 \mathrm{~km}$ apart. In an experimental approach on peatland in Great Britain, Payne and Gehrels (2010) showed that over a six-year period, tephra-derived shards moved as far as $15 \mathrm{~cm}$ down through the peat but the vast majority of grains remained at the peat surface at time of deposition, forming a layer which accurately recorded the palaeosurface. Glass shards moved both down, sinking through the peat, and up, with shards probably being moved by plant growth or with water table variability. Payne and Gehrels (2010) concluded that the extent of shard movement most likely depended on the density and porosity of the surface peat and that there was no simple relationship with wetness.

In northern Iceland, Boygle (1999) used multiple cores and sections (together with microprobe-derived analyses of glass shards) to reconstruct a primary tephrostratigraphy for the region from lakes and catchments and to identify secondary deposits. She demonstrated that a single core or site is not sufficient to develop a regional stratigraphic record because of erosion and reworking, and that composite overlapping records, rather than a principal reference section or core, may be required to develop a comprehensive record (see also Turner et al., 2009; Schiff et al., 2010). A similar finding was reported for northern New Zealand at Lake Maratoto where Green and Lowe (1985) and Lowe (1988b) used 33 lake cores in total, and multiple peat cores, to reconstruct the lake's tephrostratigraphic record and its developmental history since ca. $20 \mathrm{ka} \mathrm{cal}$ BP. Davies et al. (2001) showed that the black basaltic tephra component associated with the Vedde Ash in Loch Ashik on the Isle of Skye, the Inner Hebrides, Scotland, was prominent in some cores but was not visible in others, possibly as a result of winnowing by a small stream which enters the basin on its western side. These authors pointed out that such within-site 
variability may also be typical of other sites and that site investigations thus must be thorough if the true geographical distribution and stratigraphical sequence of individual tephras is to be established. Pyne-O’Donnell (in press) subsequently confirmed these conclusions and demonstrated from a very detailed study of multiple cores from three small Scottish lakes (including Loch Ashik) that maximal distal ash concentrations in small lakes vary significantly with catchment size and the presence or absence of catchment inlets, and that cryptotephras thus behave in a similar manner to visible tephra deposits in larger lakes (Mangerud et al., 1984). Pyne-O'Donnell (in press) also showed that maximal ash-deposition locations varied significantly during the last glacial-interglacial transition: maxima lateglacial concentrations of Penifiler Tephra, VeddeAsh, and possibly Borrobol Tephra were proximal to catchment inlets, whereas early Holocene concentration maxima of Ashik Tephra and Saksunarvatn Ash occurred predominantly in central lake sediments. High-resolution analysis through the visible Vedde Ash layer indicated that small-scale geographic and stratigraphic taphonomic processes are complex and require careful interpretation, but that the results, however, may provide inferences about local catchment conditions at the time of deposition as well as about the relative timing of inputs from the catchment (Pyne-O’Donnell, in press). As noted also by Boygle (1999), actual tephrareworking events may help to identify environmental or climatic change events, a conclusion parallel to that reached by Newnham et al. (1998b) regarding human-induced environmental disturbance in New Zealand at the time of initial land settlement that was approximately coincident with the eruption of Kaharoa Tephra ca. 1314 AD.

In limnic sediments in the Reinberg basin in northeast Germany, de Klerk et al. (2008) used the presence or absence of glauconite, derived from catchment fluvioglacial deposits, to show that the lower part of the Laacher See tephra (ca. $12.9 \mathrm{ka}$ cal BP) had been deposited as a primary fall deposit (comprising dominantly glass shards with no glauconite) whereas the upper part (glass shards admixed with glauconite) was washed in from the surrounding catchments. 
Various other laboratory analyses can also provide clues that tephra reworking has occurred. For example, partial rounding of grains in a tephra layer and the loss of glassy coatings from fresh crystals both point towards a reworking event (e.g., Wilcox and Naeser, 1992; Leahy, 1997). If the major element concentrations of glass shards in a tephra are normally homogenous (i.e., analyses of individual shards show only small deviations from one shard to the next), then multiple populations of such shards indicate that post-depositional mixing has probably occurred, or that two or more tephras were deposited effectively simultaneously from closely-spaced eruptions (Lacasse et al., 1998; Davies et al., 2004a; Shane et al., 2006). For example, postdepositional mixing was invoked as the most likely explanation for the heterogeneity of four basaltic cryptotephras in core MD99-2269 near Iceland (Kristjánsdóttir et al., 2007). To interpret such mixing therefore requires a comprehensive knowledge of compositional range because tephras generated by multiple or mixed magmas are inherently heterogeneous. In the latter case, multiple populations would not indicate reworking, rather primary petrological control. Sometimes the cause of heterogeneity remains ambiguous, however.

Additional evidence such as palynostratigraphy may assist in establishing if a tephra layer had been reworked or not. For instance, the presence of adventive pollen taxa within or adjacent to a tephra layer known to be of pre-historic age indicates that the layer must have been reworked at or after the date of arrival of the adventive taxa (Newnham and Lowe, 1999).

\subsection{Defining and using type and auxiliary reference locations}

It is important to appreciate that tephra correlation operates at several levels: (1) matching or tracing single or multiple tephra/cryptotephra units from one outcrop or core to the next, (2) matching those units to likely volcanic source or provenance, and then (3) to formally-named tephra deposits that have been characterized and defined previously at type locations (stratotype) or at auxiliary reference locations (hypostratotype or parastratotype) that include sections or 
sediment cores containing regionally comprehensive sequences of tephra deposits (e.g., Wulf et al., 2004, 2008; Lowe et al., 2007). Such locations or sequences are often relatively close to volcanic sources, but not always (e.g., Allan et al., 2008; Svensson et al., 2008), and stratotypes or parastratotypes themselves may comprise cores of sediment, not necessarily outcrops or sections on dry land. For example, a parastratotype for the mid-Holocene Tuhua tephra in northern New Zealand (derived from an offshore peralkaline volcano Mayor Island, known also as Tuhua) is a core from Kopouatai bog, a location selected because only in such deposits is the tephra uncontaminated by adjacent calcalkaline tephra beds, being separated from them by intervening peat (Hogg and McCraw, 1983). Similarly, chronostratigraphic boundaries or datum points such as the Matuyama-Bruhnes boundary may be defined wholly, or at least constrained stratigraphically, by one or more tephra layers (e.g., Naish et al., 1996, 1998; Newnham et al., 1999b; Pillans, 2003). Global auxiliary stratotypes (effectively regional reference locations) for the Pleistocene-Holocene boundary in Australasia, Europe, and East Asia were defined, respectively, using tephra layers in lake sediment cores: Konini tephra (New Zealand), Ulmener Maar tephra (Germany), and U-Oki tephra (Japan) (Walker et al., 2009).

A potential difficulty arises where the number or sequence of tephras erupted from a volcano is not known fully (as noted previously in Section 2.2), and thus distal units may not be correlatable (e.g., Alloway et al., 2004a; Kuehn and Negrini, 2010), or may be miscorrelated. In defining and naming new tephras, or re-defining them, the usual rules of stratigraphic nomenclature apply but the need for care is emphasised and specialist guidance should be sought to avoid compounding any previous correlation errors or misnomers (Lowe, 1986a; Wilson, 1993; Shane et al., 2003a; Davies et al., 2004a; Westgate et al., 2008). In the first instance, applying unique 'names' to new tephras (such as core number and depth of occurrence) is the optimum approach to reduce confusion and potential ambiguity if additional tephras are discovered during subsequent research (e.g., Bourne et al., in press). When two named tephras are correlated, it is necessary to indicate the equivalence in publications - for example, Black Pumice 
Tuff (=J-7) (Feibel, 1999). This equivalence makes clear the stratigraphic relationships in the terminology of related local sequences. The names should be rationalised in subsequent revisions with due cognizance to historical precedence and prior useage (e.g., Froggatt and Lowe, 1990; Kohn et al., 1992).

\section{Tephra fingerprinting}

\subsection{Tephra characterization and correlation: principles}

Tephra characterization or 'fingerprinting' is undertaken using a range of analytical methods that are applied to mineral assemblages or to individual glass shards, free crystals, or phenocrysts or microcrysts (Table 2; Westgate and Gorton, 1981). Such analyses are almost always undertaken in conjunction with stratigraphic, palaeoenvironmental (sometimes archaeological), and chronological criteria. Age data are useful in constraining the number of contenders for correlation or for distinguishing two tephras, for example those that are compositionally identical but which were erupted some hundreds to thousands of years apart (i.e., sufficiently separated in time so that high-precision ages obtained on both can probably enable them to be distinguished). At proximal locations, a range of physical and textural features can be used in addition to glass morphology and vesicularity to characterize tephras (e.g., Newton et al., 2007; Cioni et al., 2008). 


\section{Table 2}

Summary of main analytical methods (excluding geochronology) used over the past decade to characterize glass or free crystals in tephras to facilitate their correlation (after Lowe et al., 2008a).

\begin{tabular}{|c|c|}
\hline Tephra components and properties & Methods of analysis \\
\hline \multicolumn{2}{|l|}{ Glass shards or selvedges } \\
\hline Major elements & Electron microprobe \\
\hline Rare-earth and trace elements & LA- or SN-ICPMS, INAA, SSMS, SIMS ${ }^{\mathrm{a}}$ \\
\hline Shard morphology & Optical microscope, SEM $^{\mathrm{a}}$ \\
\hline \multicolumn{2}{|l|}{ Fe-Ti oxides } \\
\hline Major and minor elements in crystals & $\begin{array}{l}\text { Electron microprobe, Mössbauer } \\
\text { spectroscopy }\end{array}$ \\
\hline Eruption temperatures and oxygen fugacities & Electron microprobe \\
\hline \multicolumn{2}{|l|}{ Ferromagnesian minerals } \\
\hline Assemblages & Petrographic microscope $^{\mathrm{b}}$ \\
\hline Pyroxenes, amphiboles, olivine, biotite crystals & Electron microprobe \\
\hline \multicolumn{2}{|l|}{ Feldspars } \\
\hline Anorthite (An) content of plagioclase crystals & Electron microprobe \\
\hline
\end{tabular}

${ }^{a}$ LA- or SN-ICPMS, laser ablation or solution nebulisation inductively coupled plasma mass spectrometry; INAA, instrumental neutron activation analysis; SSMS, spark source mass spectrometry (now uncommon); SIMS, secondary ionization mass spectrometry (known also as ion probe/microprobe); SEM, scanning electron microscopy. Measurements of the refractive index (RI) of glass shards and also free crystals were widely used prior to the advent of the electron microprobe; high-precision RI methods for glass and crystals (e.g., cummingtonite) remain in limited use (e.g., Danhara et al., 1992; Soles et al., 1995; Nakamura et al., 2002; Enache and Cumming, 2006; Matsu'ura et al., submitted for publication) ${ }^{b}$ Where crystal quantities are abundant, ferromagnesian minerals may be identified using X-ray diffraction

Glass composition approximates the composition of the magma at the time of its eruption and, because of the complexity of the eruptive processes, provides a potentially unique signature or 'fingerprint' (Tryon et al., 2008). However, because some tephra layers in reality are closely similar to others compositionally, they are strictly not unique and hence 'fingerprinting' in this sense is a misnomer. For example, many Icelandic tephras produced by different eruptions tend to have very similar major element geochemical compositions (Larsen and Eiríksson, 2007;

Brendryen et al., 2010). Most Holocene tephras erupted from Taupo volcano in New Zealand are also compositionally similar to one another with respect to their major element compositions (e.g., Stokes and Lowe, 1988). Consequently, multiple criteria - more than one line of evidence are commonly necessary to reveal firstly a tephra's provenance (source volcano) and then to 
facilitate correlation with an individual eruptive with high probability. For example, stratigraphic position, especially with respect to a well-characterized marker bed, together with glass morphology, ferromagnesian mineralogical assemblage, glass-shard major-element composition, and palaeoecological or archaeological context, may all be needed to distinguish one tephra layer from another. According to Tryon et al. (2008), correlations between tephra deposits are best considered testable hypotheses, subject to continual revision with expanded datasets. Consequently, in general "the strongest correlations are those that show concordance between multiple independent datasets, including stratigraphic, fossil, chronological, and geochemical evidence" (p. 655). In effect, prior correlations proposed on the basis of age equivalence (i.e., stratigraphic criteria including palaeoecological or archaeological context) are tested by examining potential correlatives suggested by mineralogical variations or by geochemical variation within the glass or crystal phases of tephra deposits, or by radiometric assay of appropriate materials associated with the tephras (Lowe, 2008b; Tryon et al., 2008).

Where mineralogical and major-element data are unavailable, or prove insufficient or equivocal, then the next step is to obtain analyses on glass of trace and rare-earth elements (REEs) (Pearce et al., 2002, 2007; Knott et al., 2007; Allan et al., 2008; Turney et al., 2008; Kuehn et al., 2009). A recent example of such a situation is that for the Sheep Creek group of tephras in western Canada and Alaska as described by Westgate et al. (2008). 'Sheep Creek tephra' was formerly thought to be one tephra layer spread widely across central Alaska and western Yukon. On the basis of newly obtained major- and (especially) trace-element analyses on glass, it is now known to comprise a 'family' of five stratigraphically separate tephra beds (SCtF, SCt-CC, SCt-C, SCt-K, and SCt-A) that closely resemble one another compositionally. In the same broad region, and in contrast, the major- and trace-element geochemistry of glass and $\mathrm{Fe}-\mathrm{Ti}$ oxides of the Old Crow tephra, and its stratigraphic and paleoecological context, were all used together to indicate that it is the result of a single cataclysmic eruption ca. 124 ka. Previously, it 
had been suggested that the Old Crow tephra might represent more than one volcanic eruption (Preece et al., in press).

\subsection{Glass-shard morphology}

Glass shards may be distinguished from crystalline siliceous material by their isotropy, whereby grains of glass, which is non-crystalline and isotropic, become black under a polarizing microscope with both analyzers in place. Shards exhibit a range of morphologies and hence in favourable circumstances may provide a means for helping to distinguish one tephra from another, typically using scanning electron microscopy (SEM) to enhance optical microscopy. A useful method for mounting glass for morphological study by SEM, and which also enables subsequent geochemical analysis of the same grains, was described by Kuehn and Froese (2010).

Three main types of glass morphology have been described: (1) bubble-wall or cuspate shards, (2) platy shards, and (3) pumiceous or 'inflated' shards (Fig. 8), although other shapes (e.g., blocky, droplets, tear-drops) also occur according to magma composition, volcano eruption style, and other factors (Fisher and Schminke, 1984; Rose and Chesner, 1987; Heiken and Wohletz, 1991; Shane and Smith, 2000). 

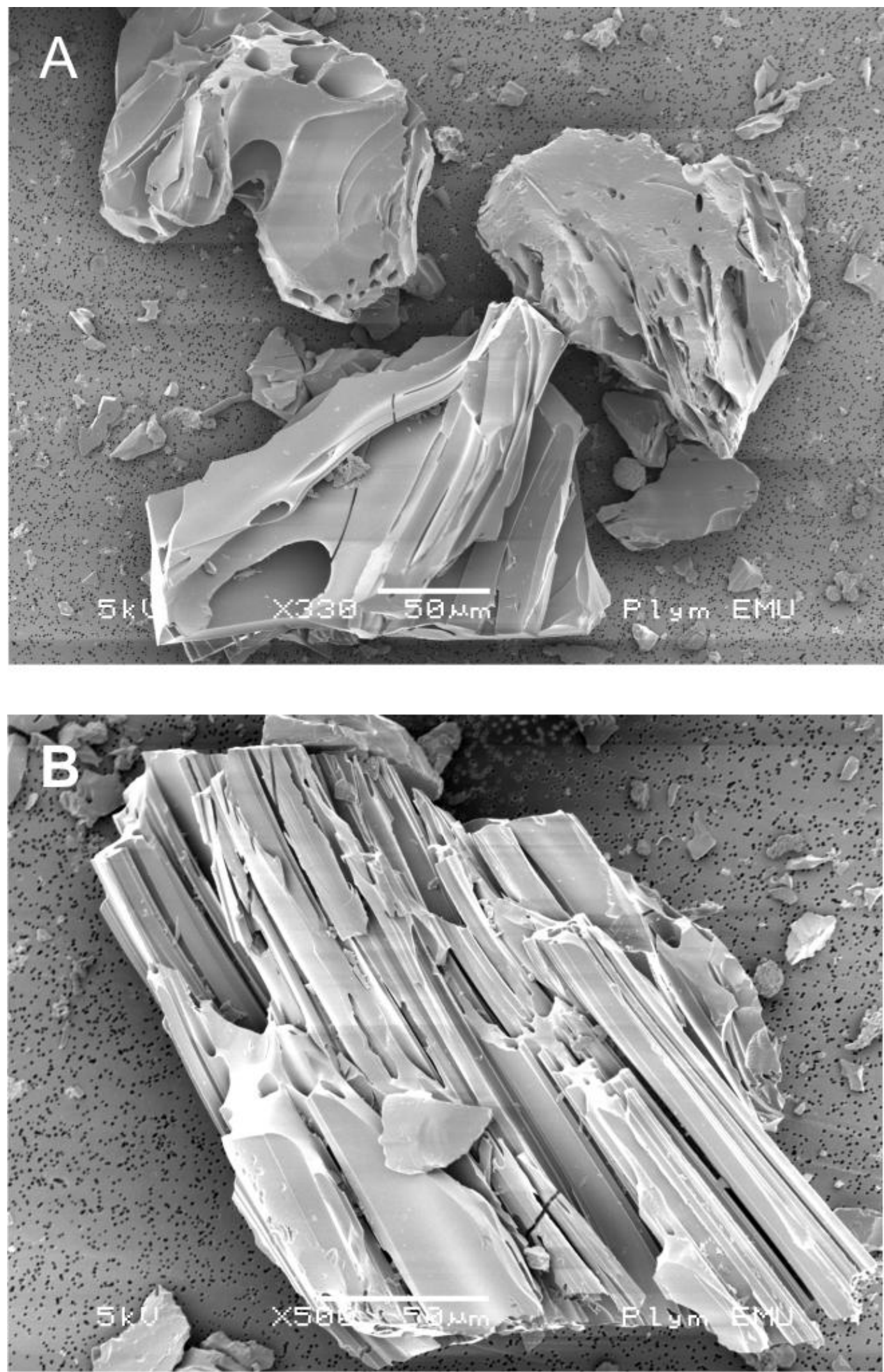

Fig. 8. Scanning electron micrographs of mid-Holocene rhyolitic glass shards extracted from Kopouatai bog near Hamilton, North Island, New Zealand (from Gehrels et al., 2006, p. 176). A. Thick-walled, cuspate shards (representing shattered bubbles with large to very large diameters) with moderate vesicularity and a low degree of stretching. B. Large pumiceous or 'inflated' shard with high degrees of stretching and vesicularity. Descriptors based on Nelson et al. (1985).

Photos: M.J. Gehrels 
Nelson et al. (1985) developed a nine-point classification of shard morphologies based on the degree of vesicularity ( 3 classes) and the degree of stretching ( 3 classes) (pertaining to pumiceous/inflated shards), and also a range of seven classes of bubble-wall shards based on bubble-wall thickness ( 3 classes) and bubble diameter (4 classes). Placzek et al. (2009) used a six-class scale. Fractal analysis has been used more recently to quantitatively define the complexity of volcanic particle morphologies, including through use of the fractal spectrum, which is a series of fractal dimensions calculated over a range of scales for each particle based on the dilation of its outline (Carey et al., 2000; Maria and Carey, 2002; Scasso and Carey, 2005). Hamann et al. (2010) used ANOVA (analysis of variance) analyses of fractal dimension values of glass particles of a distal ca. $8.8 \mathrm{ka}$ cal BP tephra, $\mathrm{S} 1$, in a marine core from the eastern Mediterranean Sea (Levantine Sea) to help correlate it with the 'Dikkartin' dome eruptives of Erciyes Dağ volcano in Turkey. They found that the high fractal dimensions of the glass fragments of S1 reflected sharp, irregular surfaces and broken vesicle walls indicative of a 'dry' eruption characteristic of the 'Dikkartin' eruption in the central Anatolian volcanic province rather than contemporary phreatomagmatic eruptions, which produced glasses with low fractal dimensions, in other volcanic provinces.

Another example of a study where the glass morphology, together with mineral content and geochemistry of tephra beds, helped to reveal provenance is that of Preece et al. (2000). They showed that tephra beds from the Aleutian arc-Alaska Peninsula, described as Type I beds, contained mainly bubble-wall shards and had low crystal contents (mainly pyroxene). In contrast, tephra beds from the Wrangell volcanic field and Hayes volcano, described as Type II beds, contained glass mainly in the form of highly inflated pumice and had many more crystals (mainly the amphibole, hornblende) (Preece et al., 2000; Froese et al., 2009). Blockely et al. (2007a) used glass-shard morphology to help characterize and hence map the distribution of Vedde Ash from Iceland to central Europe. 


\subsection{Mineral assemblages (petrography)}

A common method for characterizing tephras is through optical microscopy (using a petrographic or polarizing microscope) to identify ferromagnesian mineralogical assemblages where such minerals are relatively common to abundant. Attributes such as pleochroism, angle of extinction, relief, and birefringence are utilized in the identification process (mineral identifications ideally are confirmed using EPMA on selected crystals). X-ray diffraction analysis can additionally be used as an identification tool where mineral quantities are high, as tends to occur near source or with eruptives rich in ferromagnesian crystals (e.g., Inoue et al., 2009). Ferromagnesian minerals (and Fe-Ti oxides) tend to be sparse or absent at more distal localities, having dropped out earlier from proximal ash clouds mainly because of their high specific gravity (Sarna-Wojcicki et al., 1981b; Juvigné and Porter, 1985). These minerals can be extracted and purified using magnetic separators (e.g., Frantz Magnetic Separator) together with density separation (flotation) methods using non-toxic heavy liquids such as sodium polytungstate $\left[\mathrm{Na}_{6}\left(\mathrm{H}_{2} \mathrm{~W}_{12} \mathrm{O}_{40}\right) \mathrm{H}_{2} \mathrm{O}\right]$. The abundance of ferromagnesian crystals and Fe-Ti oxides (together referred to as heavy minerals) may offer a strong clue regarding tephra source (volcanic provenance) (e.g., Lowe, 1988a; Preece et al., 2000). For example, post-18 ka cal BP tephras in northern New Zealand, between ca. 100-200 km from source and derived from the andesitic Tongariro and Egmont/Taranaki volcanoes, have a relatively high content of heavy minerals $(\sim 15-25 \%)$ but a lower content of Fe-Ti oxides ( 10\%). In contrast, the rhyolitic Taupo and Okataina volcano-derived tephras in the same region are low in heavy minerals $(<\sim 5 \%)$ but relatively high in oxides ( 20-30\%), especially Okataina eruptives, and the peralkaline Mayor Island-volcano-derived tephras are very low both in heavy minerals $(\sim 1 \%)$ and oxides $(\sim 5 \%)$ (Lowe, 1988a, 1988b).

With stratigraphic and other constraints, the relative abundances of different sorts of crystals within the ferromagnesian mineral assemblages may allow a source volcano to be 
identified. For example, in post-27 ka cal BP rhyolitic tephras in New Zealand, orthopyroxene is always dominant in Taupo volcano-derived tephras whereas biotite, hornblende, cummingtonite, or orthopyroxene may predominate in tephras derived from nearby Okataina volcano (Fig. 9). Similarly, andesitic eruptives in New Zealand may be distinguished from rhyolitic tephras because of their abundance of pyroxene, or of hornblende together with clinopyroxene (Lowe et al., 2008a).

Sometimes a mineral assemblage is sufficiently distinctive or unusual for an individual tephra to be readily identified by just a few grains of a 'marker' mineral. Such a case is that of the ca. $7.0 \mathrm{ka}$ cal BP Tuhua tephra from Mayor Island, which is characterized by a distinctive, bright green sodium-rich clinopyroxene called aegirine (Hogg and McCraw, 1983; Lowe, 1988b; Fig. 9C). However, the absence of diagnostic minerals does not necessarily negate identification because minerals such as olivine are soon altered or depleted by weathering, and biotite and orthopyroxene may be rapidly dissolved in some acid peat bogs (Hodder et al., 1991). Furthermore, certain eruptives (such as late Quaternary tephras from Okataina volcano) may comprise multiple magma types and hence the use of ferromagnesian minerals for tephra correlation purposes may be complex (Lowe et al., 2008a). 


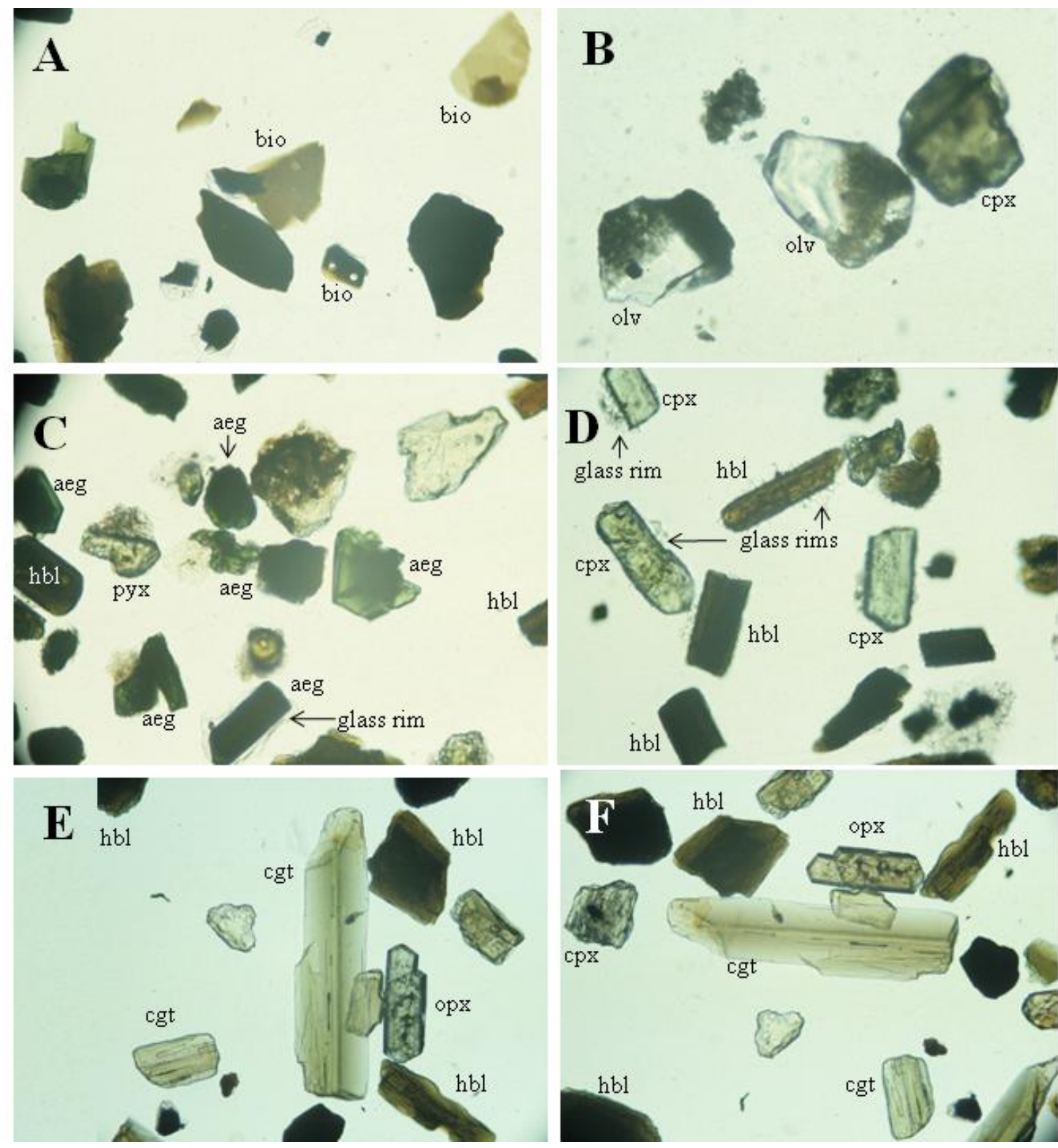

Fig. 9. Photomicrographs (all under plane polarized light) illustrating different ferromagnesian minerals (as free crystals, some with 'ripped' edges, in 63-250 $\mu \mathrm{m}$ size fractions) characteristic of some late Quaternary tephra sources in North Island, New Zealand (see Lowe et al., 2008a). Glassy coatings or rims are visible on some of the crystals or crystal fragments. A. Mainly biotite (from rhyolitic Rerewhakaaitu tephra: Mt Tarawera, Okataina volcano). B. Fayalitic olivine (olv) (grain at left with back Cr-spinel microlite) and clinopyroxene (cpx) (from andesitic Mangamate tephra: Tongariro volcanic centre). C. Aegirine (aeg) with hornblende (hbe) and pyroxene (pyx) (from peralkaline Tuhua tephra: Mayor Island/Tuhua volcano). D. Hornblende (hbe) and clinopyroxene (cpx) assemblage (from andesitic Konini tephra: Egmont/Taranaki volcano). E. Cummingtonite (cgt, note low relief), hornblende (hbe), and orthopyroxene (opx, note high relief) assemblage (from Rotoma tephra: Rotoma subcaldera, Okataina volcano). F. As for (E) but rotated 90 degrees to show weak pleochroism of cummingtonite, which changes from pale green to pale pink, and strong pleochroism of orthopyroxene, which changes from green to orange. Photos: D.J. Lowe. (For interpretation of the references to colour in this and other figure captions, the reader is referred to the web version of this article.) 


\subsection{Electron probe microanalysis of glass}

Electron probe microanalysis (EPMA) is now widely adopted in tephra studies as a cornerstone technique for determining the major element composition of individual glass shards rather than bulk (multiparticle) samples. Bulk samples of tephra are of limited use for geochemical fingerprinting studies because the composition can be affected by variable phenocryst (mineral inclusion) content and because many deposits are inherently prone to impurities such as xenocrysts and xenoliths and detrital grains that are unrelated magmatically to the eruptive under analysis (Shane, 2000) - i.e., they may contain accessory and/or accidental material as well as juvenile ejecta. Samples of glass should be purified as much as possible (although complete purification is not essential because shards can usually be selected optically during analysis) to enable probing to be undertaken efficiently, especially where individual glass shards may be difficult to distinguish from masking grains such as quartz, diatoms, or marine sponge spicules or radiolaria that possibly are present, for example, in enclosing minerogenic sediments. A range of techniques is available to separate such grains using magnetic or density methods noted above (e.g., Eden et al., 1992, 1996; Merkt et al., 1993; Turney, 1998; deMenocal and Brown, 1999). Cryptephras require special attention to concentrate and extract sparse shards through various techniques including ashing or step-wise acid/alkali digestion to remove enclosing organic matter, or density separation, as noted earlier. Filtration and centrifugal concentration methods, and continuous flow analysis systems, are used on melted ice-core samples (Dunbar et al., 2003; Kurbatov et al., 2006; Davies et al., 2008, 2010b; Kuehn and Froese, 2010).

The potential effects of some chemical separation methods on glass stability for EPMA were examined by Dugmore et al. (1992) and Blockley et al. (2005). These authors noted that small glass shards, with a high surface to volume ratio, are prone to chemical alteration via both acidic and basic treatments. They reported that the use of acid or basic 'cleaning' processes may 
risk altering the geochemical signature of the shards, and demonstrated that stepped heavy liquidbased separations were likely to provide more secure microprobe analyses of glass. Microbial attack on glass shards recovered from sediments has also been observed (Ross and Fisher, 1986; Thorseth et al., 1992; Lowe, 2008a).

In undertaking EPMA, the glass shards (or melt inclusions) must be mounted in a suitable resin that hardens. The shards are then polished to expose fresh internal surfaces, and coated in carbon (Froggatt, 1992). A step-by-step procedure for mounting and polishing glass shards (or crystals) for analysis by EPMA is given in Fig. 10. A procedure suitable for mounting sparse, fine glass shards and other materials extracted from ice cores was described by Kuehn and Froese (2010). These authors used a graphite substrate for mounting grains that enables the grains, initially unpolished, to be studied by SEM and chemically analysed by SEM-energy dispersive spectrometry at full vacuum and without the need for a conductive coating because of the close proximity of the underlying graphite. Such analyses, although much less precise than those on polished grains, provide potentially useful geochemical as well as morphological information. By marking mounts with at least three reference marks, the individual grains may be relocated later after polishing, thus enabling further analysis by EPMA or LA-ICPMS to be undertaken on exactly the same grains (Kuehn and Froese, 2010). A spreadsheet designed to facilitate the relocation of grains present on mounts that have been transferred from one analytical instrument to another, or that have been removed from and then returned to the same instrument, is available as supplementary material in Kuehn and Froese (2010). The coordinate transformation calculations in the spreadsheet require that the mounts include at least three reference positions together with $x-y$ coordinates for the grains of interest. 


\section{Block positioning}

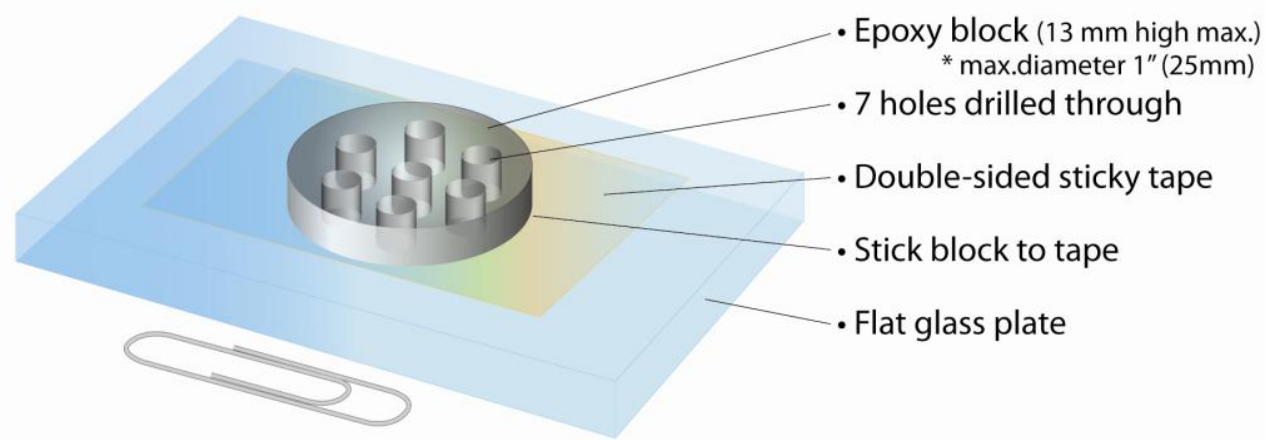

2. Add samples

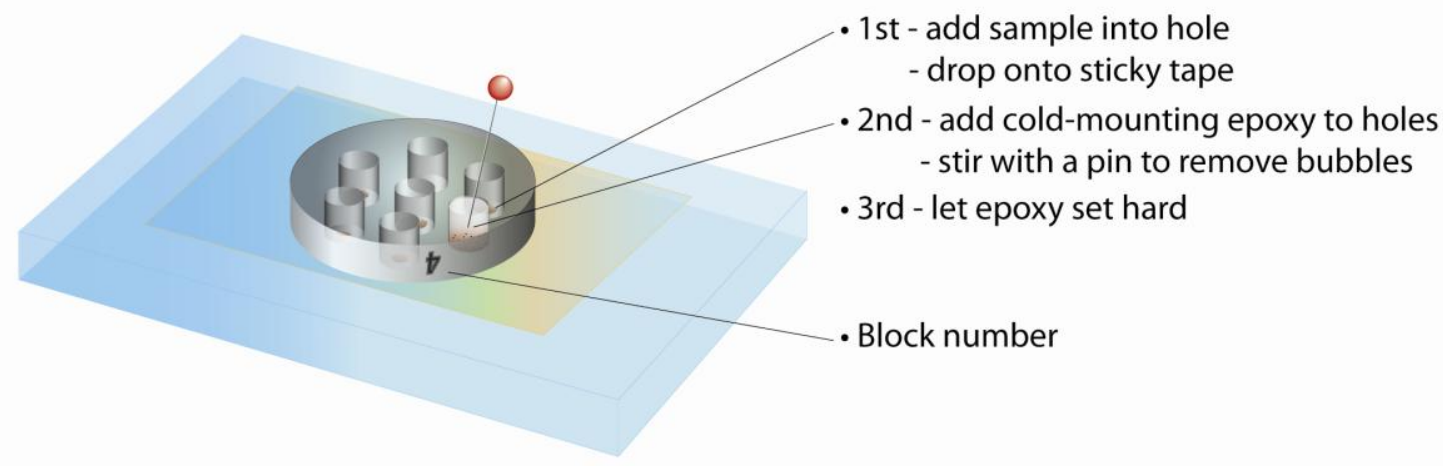

3. Invert block and remove tape from base

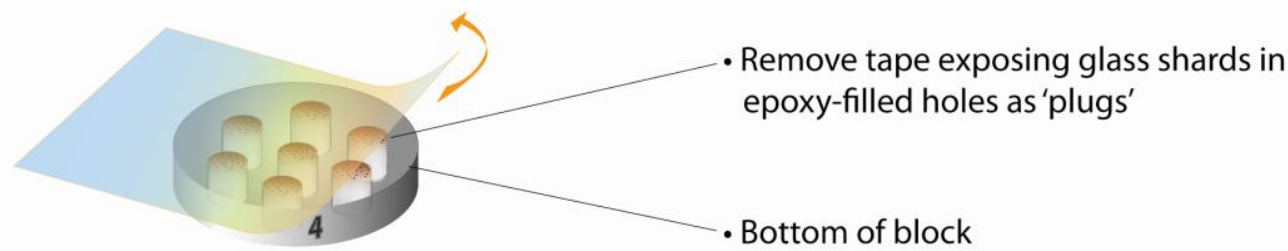

4. Grind base

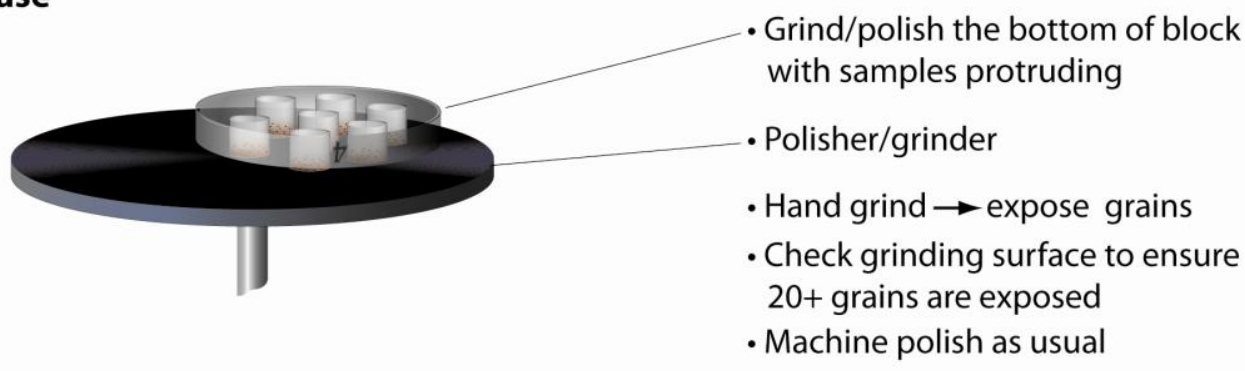

5. Polished surface

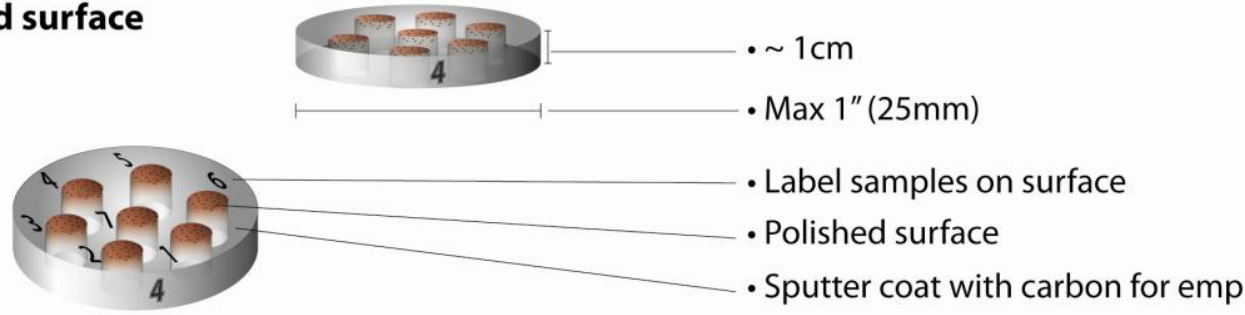

Fig. 10. Preparation procedure for mounting multiple samples of glass shards or free crystals in 'blocks' for analysis by electron microprobe, based on methods provided by Dr P.A.R. Shane, University of Auckland (after Froggatt and Gosson, 1982). An additional job is to burn three crosses $(+)$, each arm $\sim 50 \mu \mathrm{m}$ long, forming spatial $x-y$ reference points for future analyses by EPMA or LA-ICPMS (Nick Pearce pers. comm., 2010; see Kuehn and Froese, 2010). 
Glass is an amorphous solid with a poorly ordered (non-crystalline) internal structure comprising loosely linked $\mathrm{SiO}_{4}$ tetrahedra with considerable intermolecular space in which various cations such as $\mathrm{Ca}, \mathrm{Na}$, and $\mathrm{K}$ occur (Fisher and Schminke, 1984). Being non-crystalline, glass strictly is a mineraloid rather than a mineral. Because of its unique properties, glass analysis by EPMA involves some different procedures from those used to analyse most minerals (phenocrysts or free crystals), and care and understanding at each step are therefore required to obtain accurate and robust data (Froggatt, 1983, 1992; Hunt and Hill, 1993; Shane, 2000; Westgate et al., 2008; Coulter et al., 2010; Hayward, submitted for publication).

In many instances, EPMA-derived geochemical variation in major elements of glass from one tephra to the next are substantially different, enabling tephras to be easily characterized and correlated (e.g., Stokes and Lowe, 1988; Stokes et al., 1992). However, in other cases, geochemical differences can be subtle, as noted previously, and hence high levels of precision and accuracy are required for successful correlation and identification. Further, small differences between results may be produced by different laboratories (as can occur with all analytical systems) but these have been, and continue to be, addressed by use of appropriate standards and agreed protocols (Froggatt, 1992; Turney et al., 2004) and by interlaboratory comparison exercises (Hunt and Hill, 1996; Potts et al., 2002; Coulter et al., 2010). Such a comparison exercise (analogous to those that occur in the radiocarbon community) was undertaken in 2010 by the International Focus Group on Tephrochronology and Volcanism (INTAV) of INQUA, and revised EPMA protocols are being developed (Kuehn et al., 2010).

Jensen et al. (2008) and Preece et al. (in press), working in the Yukon Territory and Alaska, used existing probe-based geochemical databases to facilitate tephra correlations but additionally re-analysed samples of potential and likely correlatives from reference collections at the same time they analysed the unknown tephras to help eliminate possible small, day-to-day differences in probe calibration. 
The electron probe microanalyser method works by directing a focussed beam of electrons onto a sample, generating X-rays. The X-rays produced are of particular energies and wavelengths relating directly to individual elements, and their intensities are a measure of specific element abundance (Shane, 2000; Reed, 2005; Coulter et al., 2010). Typically, around 10 to 13 elements - Si, $\mathrm{Al}, \mathrm{Ti}, \mathrm{Fe}, \mathrm{Mn}, \mathrm{Mg}, \mathrm{Ca}, \mathrm{Na}, \mathrm{K}$, and $\mathrm{P}$, and also $\mathrm{S}, \mathrm{F}$, and $\mathrm{Cl}-$ are able to be assayed (depending in part on glass composition) (Hayward, submitted for publication). Two types of analysis are available for the detection and recording of X-ray signals: energy-dispersive spectrometry (EDS) and wavelength-dispersive spectrometry (WDS). Both EDS and WDS systems are widely used in tephra studies and the use of one or the other involves compromises (see Coulter et al., 2010, for discussion). Usually a defocussed beam (e.g., 10-20 $\mu \mathrm{m}$ in diameter), or a rastered beam extending over an area of 5 x $5 \mu \mathrm{m}$ for example, and moderate beam current, are deployed to minimise mobilisation (instability) and hence loss of $\mathrm{Na}$ in particular (also K may be underestimated, and Si and Al overestimated) (Froggatt, 1983; Hunt and Hill, 1996, 2001; Suzuki, 1996; Davies et al., 2008; Tryon et al., 2008; Coulter et al., 2010). The very small grain sizes of shards from distal deposits (such as in ice cores) may necessitate the use of narrower beam diameters. For example, a 5- $\mu$ m diameter was used by Wastegård and Davies (2009) as developed by Hayward (submitted for publication). Such narrower beams may also be necessary in probing andesitic or basaltic glasses to avoid micro-inclusions that are often present (see below).

Although Hunt and Hill (2001) showed that reducing beam sizes for electron microprobe analysis of very small shards or pumiceous shards with thin walls could lead to unreliable or distorted geochemical analyses and hence potentially invalidate correlations, more recent work has developed new protocols enabling the routine use of narrow beam diameters to $5 \mu \mathrm{m}$, and as low as $3 \mu \mathrm{m}$, without loss of $\mathrm{Na}$ (Hayward, submitted for publication). Such a development is very significant because it enables many fine-grained samples to be analysed from wider (more distal) geographic locations than previously, it reduces or prevents bias in data collection because 
most or all shards in a sample can be analysed, it enables more vesicular or microlite-rich glasses to be analysed than before, and EPMA data aquisition is more easily automated and hence potentially more cost effective (Hayward, submitted for publication). Analysis using such highly focussed beams is best facilitated with a microprobe equipped with four or, especially, five WDS spectrometers, a Large TAP analysing crystal for maximum Na sensitivity, and the ability to measure at two or three different beam currents during each analysis both to prevent $\mathrm{Na}$ loss and to provide adequate count rates for good analytical precision for other elements (Hayward, submitted for publication). $\mathrm{Na}$ and then $\mathrm{Al}$ and/or Si should be analysed first (Morgan and London, 1996, 2005). Deino et al. (2010) reported that element migration effects in EPMA analyses on glass undertaken by them were corrected for $\mathrm{Na}, \mathrm{O}$, and $\mathrm{K}$ using a quadratic, selfcalibrated correction model applied to time dependent intensity changes.

The regular analysis of both primary and secondary (including reference) standards is essential to maintain integrity of analysis and accuracy and precision. Homogenous, glassspecific standards, such as the widely-used rhyolitic Lipari rhyolitic obsidian (Froggatt, 1983; Hunt and Hill, 1996), basaltic glass from the Laki 1783 tephra, or phonolitic (high-Na) glass of the Sheep Track tephra from Mt Edziza (British Columbia), must be analysed frequently and the probe recalibrated accordingly (Kuehn et al., 2010). For example, Kuehn and Froese (2010) used UA5831, the Lipari rhyolite, for calibrating $\mathrm{Na}, \mathrm{K}, \mathrm{Al}$, and $\mathrm{Si}$, the four most abundant elements in glass from the Mt Logan ice core; five mineral standards were used to calibrate the remaining elements. Old Crow tephra (UT1434) was also analyzed repeatedly as a secondary standard to provide a check on calibration quality and to detect instrument drift (Kuehn and Froese, 2010). Tryon et al. (2008) also used a wide range of documented reference materials for calibration including ilmenite (USNM 96189), anorthite (USNM137041), bytownite (USNM R-2912), Kakanui hornblende (USNM143065), microcline (USNM 143966), and Yellowstone rhyolitic glass VG-568 (USNM7285), the last being extensively tested as their key secondary standard. EPMA analytical conditions must always be presented and it is recommended that analyses of 
primary and reference standards should also be published alongside newly-acquired glass-shard or melt inclusion data to help demonstrate the robustness of such data (Froggatt, 1992; Westgate et al., 2008).

Most tephra analysts attempt to assay around 15-20 different shards per sample (unless very few shards are available, as may occur in distal samples such as those from ice cores) in an attempt to assess its homogeneity or to look for evidence of magmatic gradients or magma mixing, or post-depositional mixing. If the shard population is compositionally homogeneous, then the analyses can be presented as a mean and standard deviation that reflects the average composition of the melt phase (Shane, 2000). However, such practise needs to be undertaken cautiously because such data are rarely tested for multivariate normality. Further, it is now evident that in some cases as many as $\sim 50$ shards per sample may require analysis because of greater compositional heterogeneity in some tephras than previously recognised (discussed below).

Typically, glass analyses are normalized to a volatile-free basis, i.e., re-calculated to sum to $100 \%$, most of the deficit being attributable to magmatic water, as demonstrated by Froggatt (1983), to avoid the effects of variable secondary hydration and to enable valid comparisons of analyses. However, the need for normalization has been disputed by some tephrochronologists because any analytical deficit (below a total of $100 \%$ ) may not be entirely attributable to water. Instead the deficit may be the result of spectrometer drift, charging, or mobilization of a specific element (Hunt and Hill, 1993; Pollard et al., 2006). If a loss of alkalis occurs then Si and Al totals especially will be artificially inflated. Also, once datasets are normalized then it has been argued that statistical treatments of data are compromised because they are no longer strictly independent (Simon Blockley pers. comm., 2010). On the other hand, others have maintained that normalization is essential (e.g., Stokes et al., 1992; Shane, 2000; Pearce et al., 2008a) because it results in consistent elemental abundances, suggesting that the water is accommodated within the glass structure without chemical alteration (Shane, 2000). Also, discriminant function analysis 
undertaken by Stokes et al. (1992) showed that such normalization provides statistically valid results. In any event, the original analytical totals should be listed, either as 'raw' non-normalized data or given as the difference between the original totals and 100 (typically expressed as 'water by difference').

Raw totals from EPMA of glass ideally should be $\geq 95$ wt\% (Froggatt, 1992; Hunt and Hill, 1993; Paczek et al., 2009). However, electron microprobe analyses of numerous New Zealand tephra-derived glasses of Quaternary and older age, and of tephras elsewhere, have analytical totals in the range 91-99 wt\%, typically 94-95 wt\%, and these data with lower totals are usually considered reliable (Shane, 2000). Nairn et al. (2004) supported this contention through careful EPMA analyses (with defocused beam and low beam current) of melt inclusions completely encased in uncracked quartz in Kaharoa pyroclastic eruptives in North Island. They argued that the water totals in such completely-sealed melt inclusions, between $\sim 6.1$ and $\sim 6.5 \mathrm{wt} \%$, must represent the true dissolved $\mathrm{H}_{2} \mathrm{O}$ content of the magma prior to eruption (see also Shane et al., 2005).

Major-element analyses of glass commonly enable volcanic provenances to be identified, and analyses of individual tephras may allow them to be distinguished using bi-plots of oxides such as $\mathrm{FeO}$ or $\mathrm{K}_{2} \mathrm{O}$ vs $\mathrm{CaO}$ content (Fig. 11), or tri-plots, or using canonical discriminant function analysis that incorporates around eight or nine major elements (discussed below). Data can also be presented graphically as histograms of standardized ratios $(I)$ calculated by determining the difference, for each oxide, between the mean oxide weight percent value for the whole dataset $(\mu)$ (or of any suitable glass standard) and the oxide weight percent value for each constituent tephra unit $(x)$, divided by the standard deviation $(s)$ for the whole dataset (SarnaWojcicki et al., 1981b; Nelson et al., 1985; Stokes et al., 1992):

$$
I=(x-\mu) / s
$$


Both raw and log-transformed data can be used. In such plots a ratio of 0.0 is attained where the analyses are identical. The log-transformation plots tend to accentuate some of the trends in the data and so this plotting procedure may be potentially useful even in the absence of subsequent DFA or other sophisticated numerical analysis (see examples in Stokes et al., 1992).

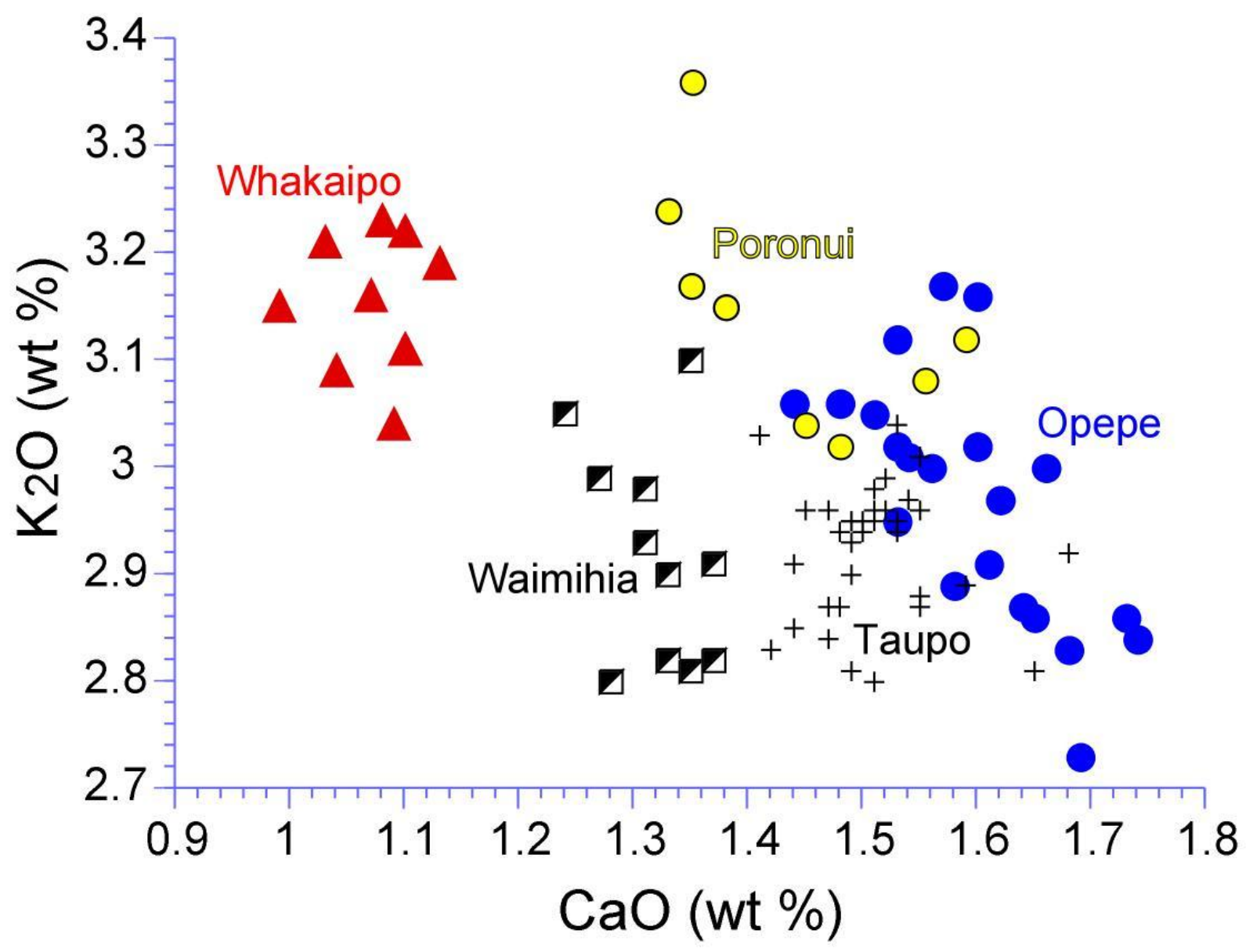

Fig. 11. Binary plot of $\mathrm{K}_{2} \mathrm{O}$ vs $\mathrm{CaO}$ (wt \%) analyses for rhyolitic glass obtained using EPMA from five Holocene Taupo-derived tephras (New Zealand) illustrating that some (Taupo, Whakaipo, Waimihia) are generally distinguishable from one another but others (Poronui, Opepe, Taupo) partly overlap hence are not clearly distinguishable using these oxides (from Lowe et al., 2008a, p. 104).

Detailed studies by EPMA of thick sequences of proximal rhyolitic to rhyodacitic tephras erupted from Okataina volcano in northern New Zealand have revealed much more compositional diversity and heterogeneity within individual lapilli-sized clasts and at different azimuths around 
the volcanic centre than previously recognised (Smith et al., 2002, 2005, 2006; Nairn et al., 2004; Kobayashi et al., 2005; Shane et al., 2005, 2008a). This heterogeneity, sometimes subtle, is a consequence of the mingling of separate batches of magma that were tapped simultaneously or sequentially, accompanied by changes in wind direction, as eruptions proceeded. The recognition of more than one magma type in some Okataina-derived tephras has in some circumstances increased their potential for precise correlation in that some tephra beds might be identified uniquely, even where stratigraphic control is uncertain, because they were derived from two or three magma batches and so have in effect multiple fingerprints (Lowe et al., 2008a). For example, the rhyolitic Rotorua (ca. 15.4 ka cal BP) and Kaharoa (ca. 1314 AD) tephras are each the product of two magmas that can be distinguished on the basis of glass chemistry, one high (> $4 \mathrm{wt} \%)$ and the other low $(\ll<\mathrm{wt} \%)$ in $\mathrm{K}_{2} \mathrm{O}$. However, it is also evident that the newlyrecognised heterogeneity has increased complexity and potential ambiguity, and glass compositions of some eruptive phases may overlap those for other tephras. The heterogeneity warns of the difficulty of characterizing (thus fingerprinting) tephra beds using a limited set of distal samples from restricted dispersal sectors (Shane et al., 2008a). Such heterogeneity is also recognised in tephra sequences elsewhere, including the central and eastern Mediterranean area (Narcisi and Vezzoli, 1999; Pearce et al., 2002; Paterne et al., 2008; Pyne-O’Donnell et al., 2008), Chile (Kratzmann et al., 2009), and Japan (Watanabe et al., 2006). In Kenya, the tephra sequences in the mid-Pleistocene Bedded Tuff eruptive complex in the Kenya Rift region were shown by Tryon and McBrearty (2002) to have an increasingly evolved composition through the stratigraphic succession, indicating that the beds were the product of intermittent eruption of a single differentiating magma system. Further heterogeneity within some beds was attributable to either the effects of weathering or to bioturbation.

The correlation of andesitic tephras using glass chemistry assay generally is more complicated than for rhyolitic tephras for various reasons including the multiplicity of eruptive units and the paucity of suitable glass for probing: shards may be very thin, highly vesicular, and 
frequently contain micro-inclusions (Fig. 12), namely microphenocrysts (> $1.2 \mu \mathrm{m}$ wide), microlites $(>0.6 \mu \mathrm{m}$ wide), or nanolites $(<0.6 \mu \mathrm{m}$ wide) using the terminology of Sharp et al. (1996). Sometimes such micro-inclusions are called microcrysts or crystallites. Also, andesitic glass is more susceptible to weathering than rhyolitic glass, meaning it can become unsuitable for analysis for correlation purposes. Consequently, wide compositional ranges may occur (Nakagawa et al., 1999; Shane et al., 2002, 2008b; Donoghue et al., 2007; Turner et al., 2009). However, Platz et al. (2007) developed an evaluation procedure using mixing calculations to reduce microprobe-determined glass heterogeneity arising from plagioclase micro-inclusions. In New Zealand, analyses of late Quaternary andesitic glass from Egmont volcano-derived tephras by Shane (2005) showed them to be enriched in $\mathrm{K}_{2} \mathrm{O}\left(>4\right.$ wt \%) and depleted in $\mathrm{CaO}$, $\mathrm{TiO}_{2}$, and $\mathrm{FeO}$ in comparison with andesitic tephras erupted from Tongariro volcano, and hence readily distinguished. Further, the compositional variation in glasses from some individual andesitic tephras allowed their discrimination within short stratigraphic intervals of ca. 5,000-10,000 years (Shane, 2005). 

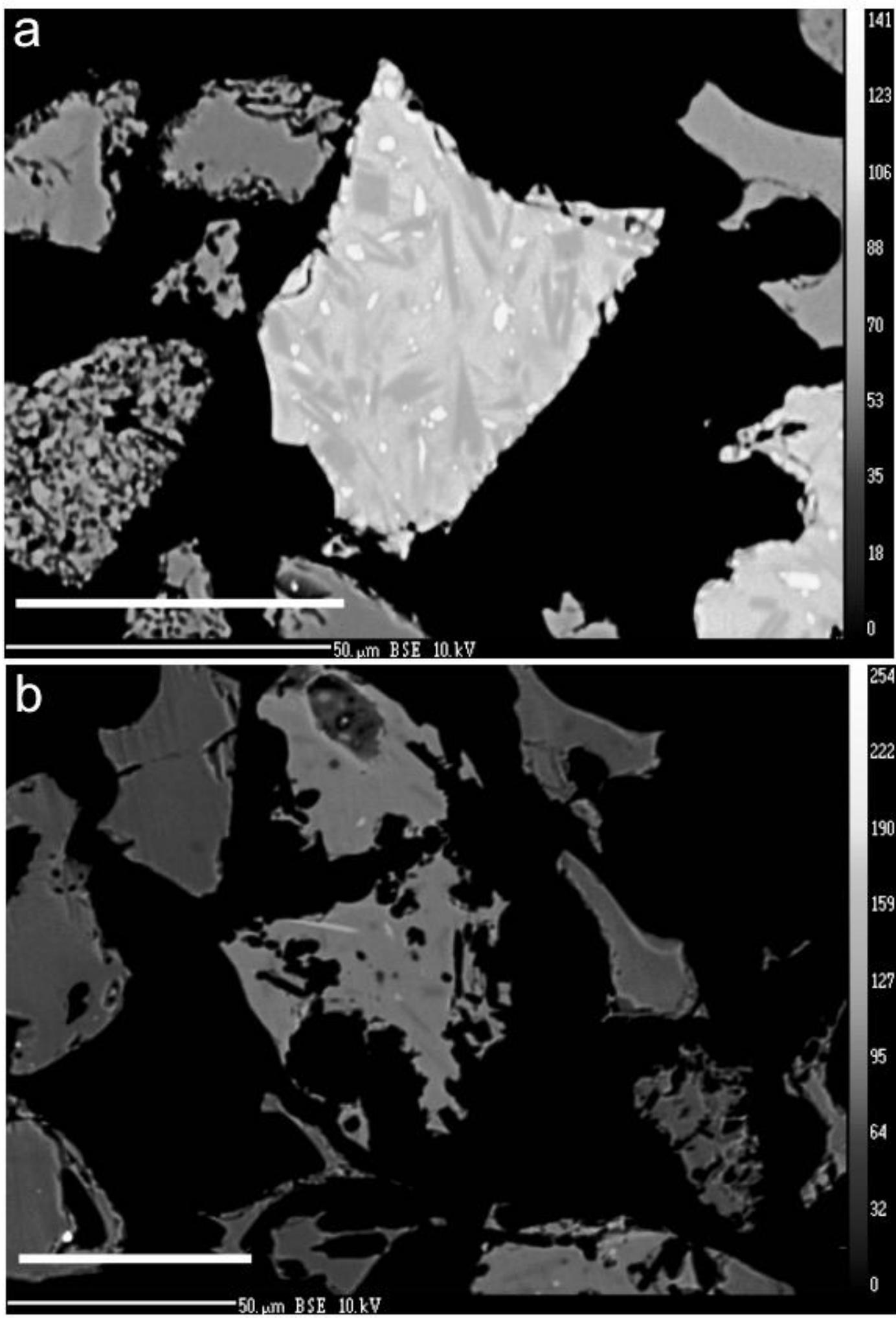

Fig. 12. Backscattered electron (BSE) images of exposed and polished inner surfaces of glass shards in resin mounts before microprobe analysis. (a) Andesitic shards with distinct microinclusions (dark micro-phenocrysts or microlites are probably plagioclase feldspars) that can pose problems in glass analysis (see text). (b) Rhyolitic glass shards, essentially free of microinclusions, appear darker in the BSE images largely because of their higher silicon content and hence lower mean atomic number $(Z)$. Both samples are from late Holocene cryptotephras preserved in peats and lake sediments near Hamilton, North Island, New Zealand. Scale bar 50 $\mu \mathrm{m}$. Photos: M.J. Gehrels 
Basaltic tephras may contain variable and abundant amounts of detrital contaminants and accidental or accessory ejecta (xenoliths, xenocrysts) and hence glass contents may be low (Sheard et al., 1993; Shane and Smith, 2000), and such glass is very vulnerable to weathering and argillisation (Pollard et al., 2003; Wolff-Boenisch et al., 2004; Churchman and Lowe, in press). Basaltic glass is commonly coloured, ranging from yellowish or golden brown to dark brown or black, and typically contains abundant micro-inclusions (Fig. 13). Shards may have a range of morphologies, as noted earlier, from highly vesicular, pumice-like types to fluidal tear-drop types and vesicular or blocky, poorly vesiculated types (Fisher and Schminke, 1984; Heiken and Wohletz, 1991; Shane and Smith, 2000; Kristjánsdóttir et al., 2007).

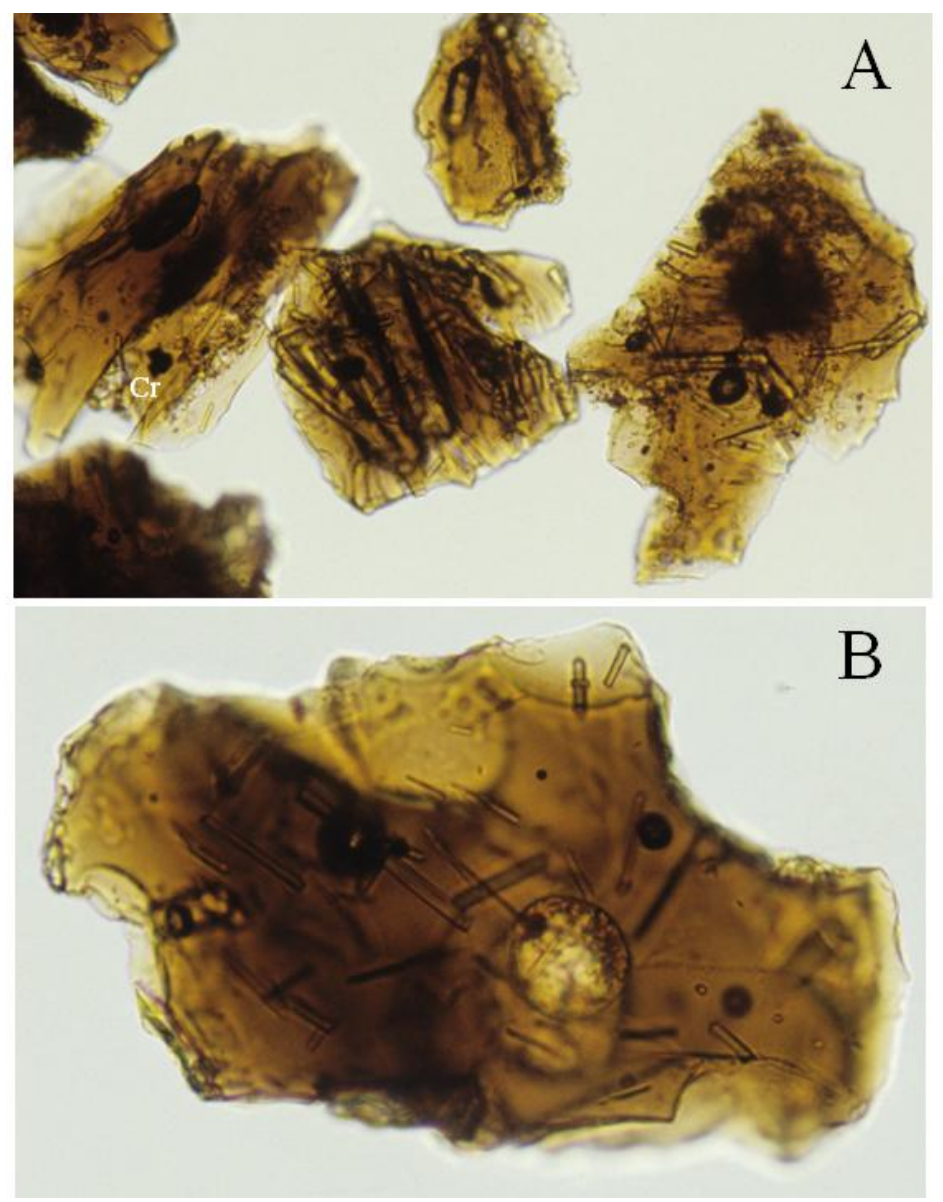

Fig. 13. Yellowish-brown ash-sized basaltic glass shards from mid-Holocene tephra erupted at Mt Gambier, southeast South Australia. A. Group of shards showing numerous prismatic microlites, probably mainly aluminian or titanian diopside ("titanaugite"), and several black $\mathrm{Cr}$ spinel microlites (Cr). Black ovoids are bubbles. B. Close-up of shard showing its curved, bubble-fractured edges and microlites of prismatic aluminian or titanian diopside (Sheard et al., 1993). Photos: R. Clayton 
Basaltic glasses from tephras in the Auckland Volcanic Field, analysed by Shane and Smith (2000) to geochemically fingerprint volcanic sources and individual eruptive events, were characterized by abundant micro-inclusions of plagioclase, pyroxene, olivine, and Fe-Ti oxides. As with andesitic glasses, these micro-inclusions required the electron beam to be positioned with care to obtain glass-only areas for analysis. Within samples in the Auckland study, there was no detectable difference in composition between shards that were mostly glass and those that were partially cryptocrystalline, however (Shane and Smith, 2000). The glasses were predominantly basanites with $\mathrm{SiO}_{2}$ contents in the range $42-50 \mathrm{wt} \%$ (Fig. 14). Many individual emplacement units were compositionally homogeneous on the basis of electron microprobe analysis $\left(\mathrm{SiO}_{2} \pm\right.$ $0.5 \mathrm{wt} \%$ ), and could be distinguished on the basis of $\mathrm{TiO}_{2}, \mathrm{CaO}, \mathrm{P}_{2} \mathrm{O}_{5}$, and $\mathrm{K}_{2} \mathrm{O}$ contents (e.g., Fig. 14). Although individual tephra beds were able to be characterized, the volcanoes are more compositionally diverse, displaying a wide range of different eruptive styles and deposits with a range in compositions $\left(\mathrm{SiO}_{2} \sim 45-50 \mathrm{wt} \%\right)$ within short stratigraphic sequences that showed no evidence of hiatuses. Such variations increased the difficulty in matching distal tephra deposits to their source (Shane and Smith, 2000; Molloy et al., 2009). 


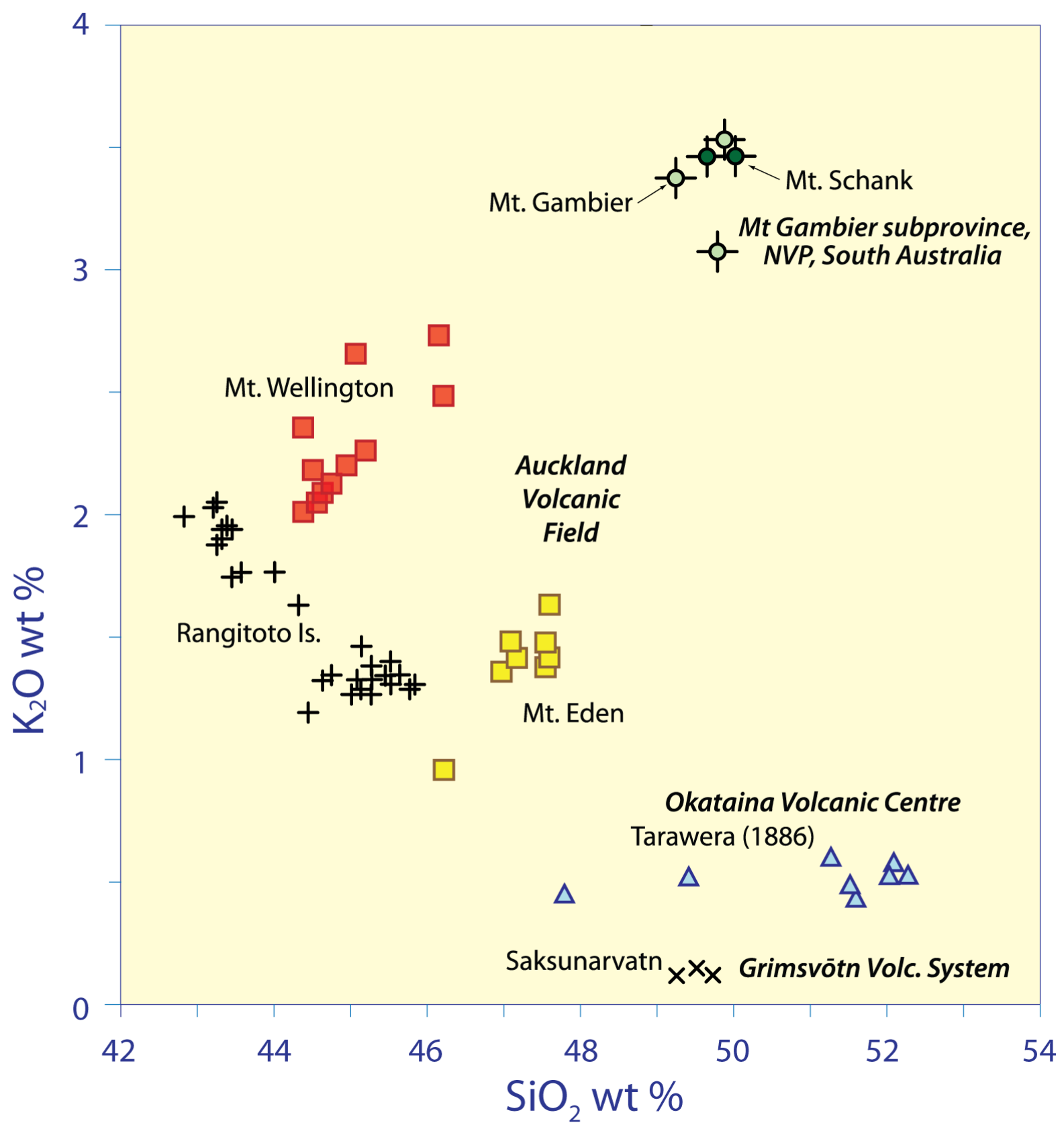

Fig. 14. Binary plot of $\mathrm{K}_{2} \mathrm{O}$ vs $\mathrm{SiO}_{2}(\mathrm{wt} \%)$ analyses for basaltic glass obtained using EPMA from tephra deposits erupted from three vent areas in the Auckland Volcanic Field and from Mt Tarawera (1886 eruption) in New Zealand (Shane and Smith, 2000), from Mts Gambier and Schank in South Australia (Sheard et al. 1993; see Fig. 13), and from Grimsvōtn in Iceland (Kristjánsdóttir et al., 2007). NVP, Newer Volcanics Province. 
6.5 Electron probe microanalysis of minerals (crystals)

As for glass, free crystals must normally be polished prior to analysis by EPMA. The compositions of plagioclase crystals, or pyroxene, amphibole, and olivine crystals, obtained by EPMA, frequently allow source volcanoes to be readily identified (Lowe, 1988a, 1988b; Smith and Leeman, 1982; Preece et al., 2000; Brauer et al., 2006; Westgate et al., 2008). In New Zealand, for example, clinopyroxene and hornblende in late Quaternary Egmont-derived andesitic tephras are typically more calcic than those from Tongariro, and hornblende from these two andesitic sources is more pargasitic than that from the rhyolitic centres (Lowe et al., 2008a). Olivine in Tongariro-derived tephras is forsteritic (Mg-rich) in contrast with that from Mayor Island (Tuhua) which is fayalitic (Fe-rich).

In favourable circumstances, individual tephras may be identified, as demonstrated by Matsu'ura et al. (submitted for publication) using analyses of cummingtonite (an amphibole) in cryptotephras preserved within loess in Japan. For biotite derived from the rhyolitic Kaharoa, Rotorua, Rerewhakaaitu, and Okareka tephras in New Zealand, the $\mathrm{FeO}$ and $\mathrm{MgO}$ contents are demonstrably different and so these tephras can be distinguished from other Okataina-derived eruptives (Shane et al., 2003b; Fig. 15). These biotite differences provided the key to identifying one of the distal tephras in the Kaipo bog sequence in eastern North Island that previously had been misidentified because its major-element glass chemistry matched that of two eruptives identical in age but derived from different volcanic sources (Shane et al., 2003a, 2003b). 


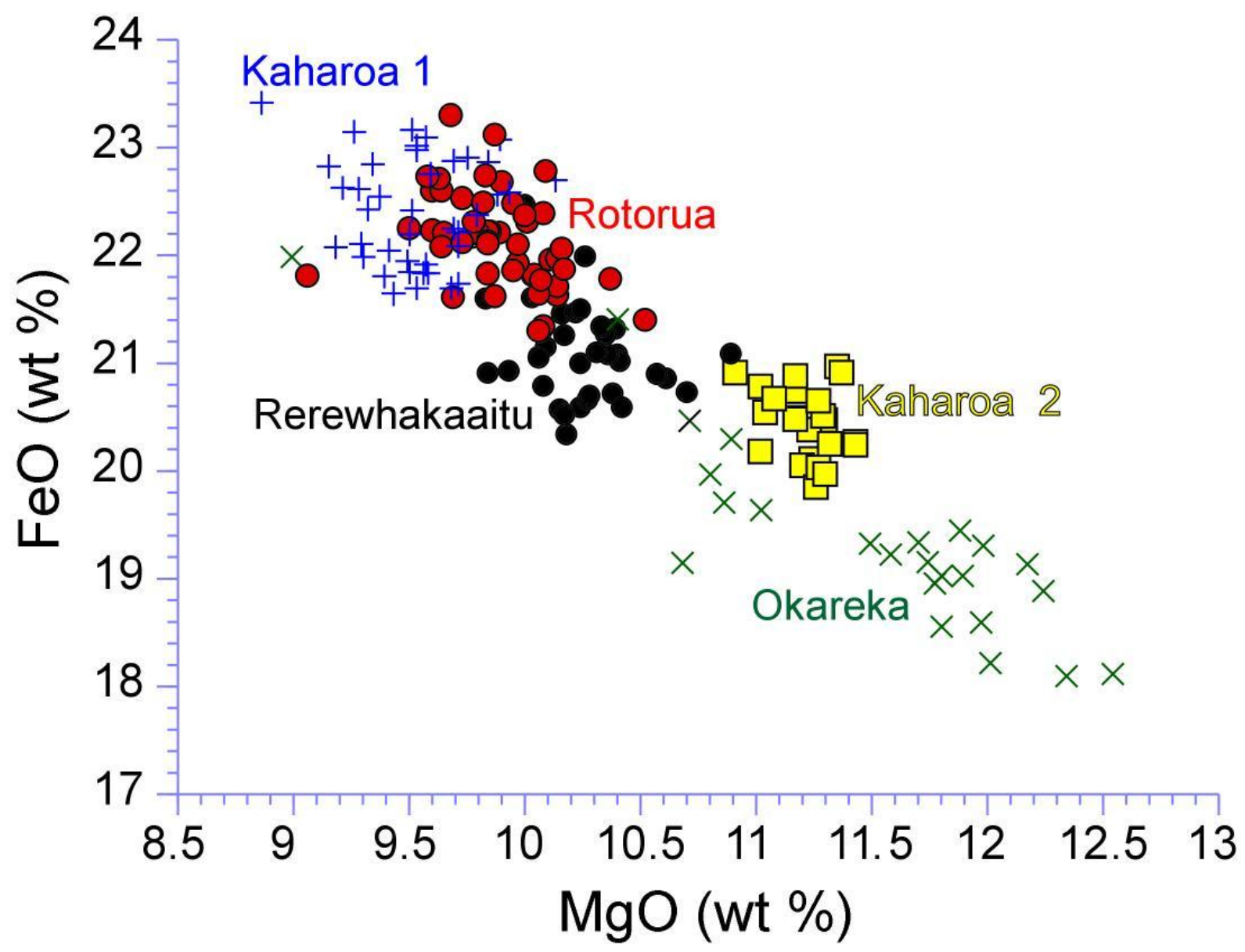

Fig. 15. Binary plot of $\mathrm{FeO}$ vs $\mathrm{MgO}$ (wt $\%$ ) of biotite analyses obtained using EPMA from four late Quaternary Okataina-derived tephras in New Zealand showing that Okareka, Rerewhakaaitu, and Rotorua tephras (all magma type T2, Lowe et al., 2008a) are distinguishable from one another. Note that late Holocene Kaharoa tephra comprises two populations relating to early (Kaharoa 1, magma type T1) and late (Kaharoa 2, magma type T2) phases of the eruption that are known to correspond to high- and low- $\mathrm{K}_{2} \mathrm{O}$ glass compositions, respectively (from Lowe et al., 2008a, p. 104).

Analyses of Fe-Ti oxides, titanomagnetite and ilmenite, by EPMA have been useful for tephra fingerprinting for many years (e.g., Westgate and Evans, 1978; Hogg and McCraw, 1983; Beaudoin and King, 1986; Julian et al., 1988; Cronin et al., 1996; Smith et al., 2002; McHenry, 2005; Turner et al., 2009). The validity of such analysis as a correlation tool was supported by crystal field theory (Hodder, 1981). Earlier work used bulk sample analyses (e.g., Kohn, 1970; Kohn and Neall, 1973; Kohn and Topping, 1978). However, partly because the distribution of FeTi oxides tends to be limited to proximal and medial sites as a result of their high density, and partly because of their more limited compositional ranges, analyses of Fe-Ti oxides have 
generally been used less frequently in more recent times than those of glass which is ubiquitous in non-weathered deposits. Nevertheless, the eruption temperature and oxygen fugacity (oxidation state of magma) of rhyolitic tephras - estimated using single-grain EPMA of Fe-Ti oxide pairs of titanomagnetite and ilmenite (geothermometry) - provide another way to distinguish and match tephras and, in some cases, magma batches within an eruptive sequence (Figs. 16-17) (Shane, 1998; Smith et al., 2002, 2005; Nairn et al., 2004; Shane et al., 2005;

Westgate et al., 2008; Preece et al., 2010). (Geothermometry using zircon analyses from tephras was reported by Charlier and Wilson, 2010.)

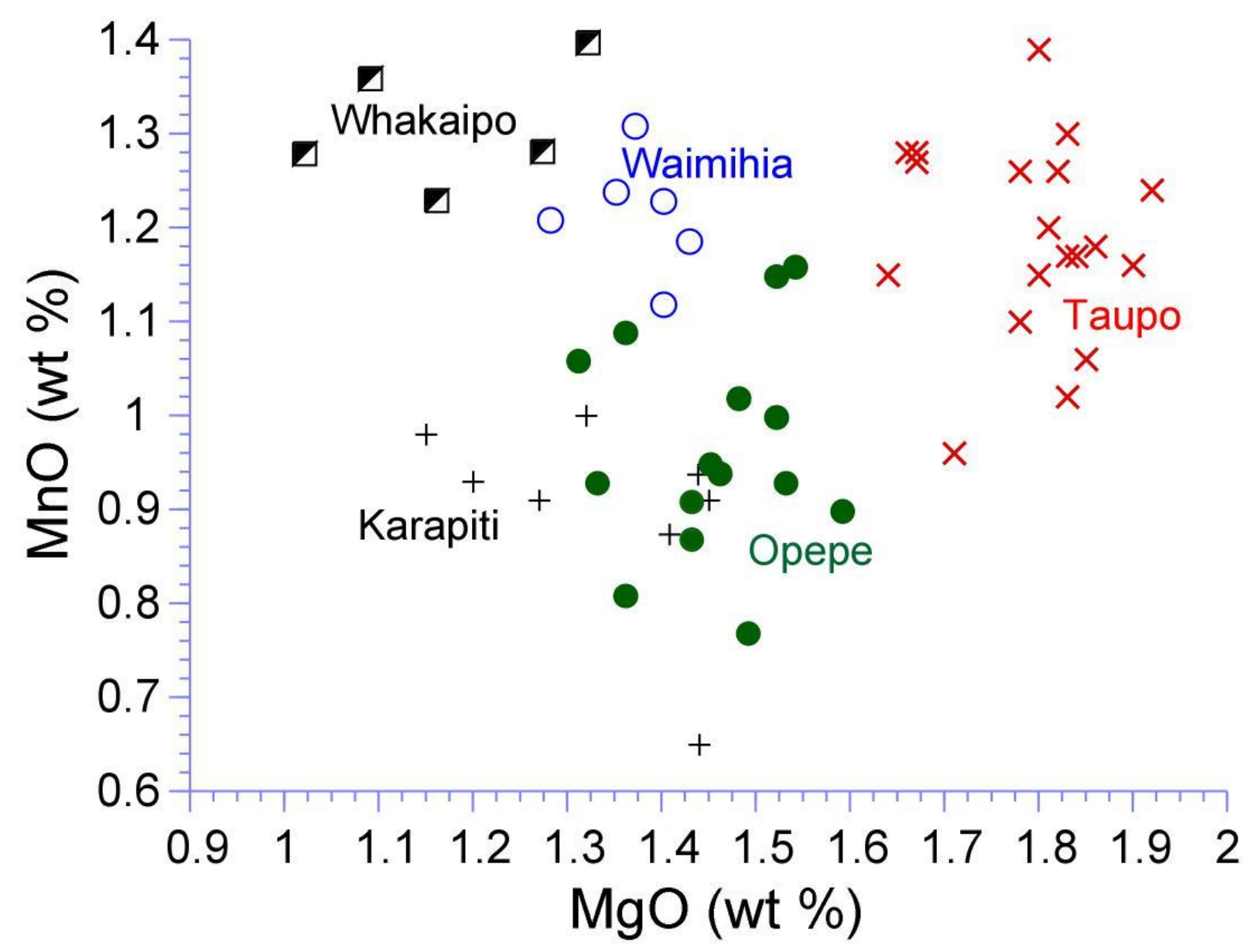

Fig. 16. Binary plot of $\mathrm{MnO}$ vs $\mathrm{MgO}$ (wt $\%$ ) analyses of ilmenites obtained using EPMA from five Taupo-derived tephras showing that Taupo, Whakaipo, and Waimihia are distinguishable from one another and from Karapiti and Opepe (from Lowe et al., 2008a, p. 104). 


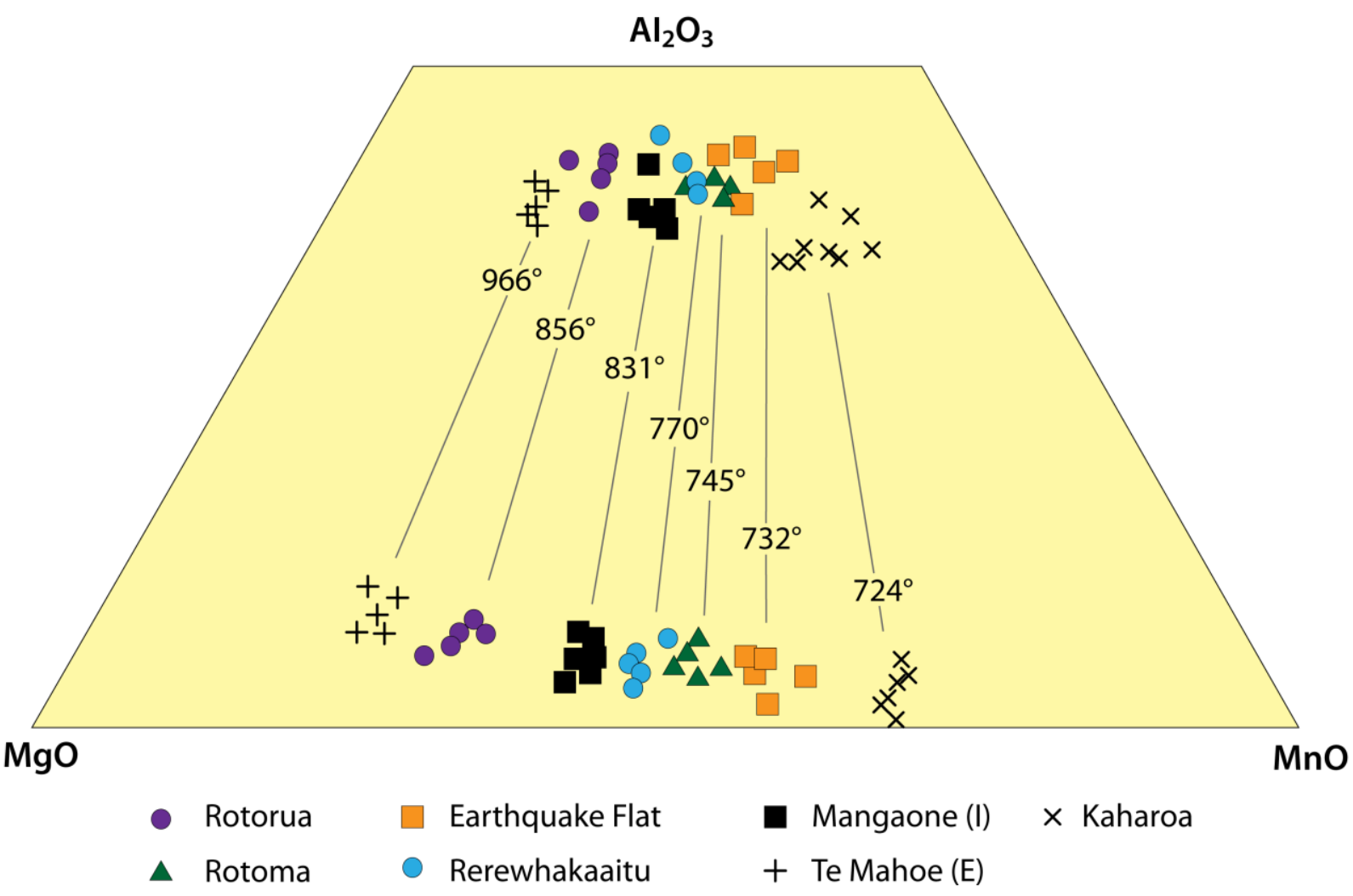

Fig. 17. Ternary plot of minor elements (obtained by EPMA) in titanomagnetites $\left(\mathrm{Al}_{2} \mathrm{O}_{3}\right.$-rich spinel phase) and illmenites $\left(\mathrm{Al}_{2} \mathrm{O}_{3}\right.$-poor rhombohedral phase) from seven late Quaternary rhyolitic to rhyodacitic tephras from Okataina volcano, and Earthquake Flat tephra from Kapenga volcano, showing their fingerprinting utility. Also shown are tie-lines with estimated eruption temperatures based on equilibrium between spinel and ilmenites (after Alloway et al., 2007a). Te Mahoe tephra, a rhyodacite, shows the highest eruption temperature (Smith et al., 2002).

Turner et al. (2008b) used contrasting titanomagnetite textures arising from fast-ascent versus slow-ascent magmas as a mineralogical tool in correlating fine-grained distal tephras. Titanomagnetites in slow-ascent eruptives showed solid-state exsolution features, namely lamellae within titanomagnetite hosts, whereas the fast-ascent eruptives contained titanomagnetites without such exsolution features.

6.6 Laser-ablation ICPMS and ion probe analysis of glass

Although early analyses of trace elements and REEs in glass using bulk (multiparticle) samples were promising (e.g., Borchardt et al., 1971; Howorth and Rankin, 1975), developments 
in laser-ablation inductively-coupled plasma mass spectrometry (LA-ICPMS) have effectively revolutionized the analysis of tephras by providing (1) an efficient and precise method for determining abundances of a wide variety of trace elements including REEs at low concentrations in individual glass shards, and thus fingerprint individual tephras (or tephra successions) of similar mineralogy or provenance, and (2) further assessment of geochemical heterogeneities within individual tephra layers (Westgate et al., 1994; Bryant et al., 1999; Pearce et al., 1996, 2004a, 2007; Nairn et al., 2004; Harangi et al., 2005). Cleaned and picked glass shards mounted, polished, carbon coated, and analysed previously by EPMA are placed in the ablation chamber of the laser system and, by using annotated images acquired during the EPMA analysis or the $x-y$ coordinate system noted earlier, the same shards can be relocated for analysis by LA-ICPMS (Fig. 18; Pearce et al., 1999, 2007). Use of a minimum of three reference points marked onto mounts enables such relocations to be undertaken accurately and easily using the spreadsheet developed by Kuehn and Froese (2010). As noted previously, the spreadsheet takes as input the $x$ $y$ stage coordinates of the three reference positions measured on the source and the target instrument and the grain (glass shard) coordinates from the source instruments. 


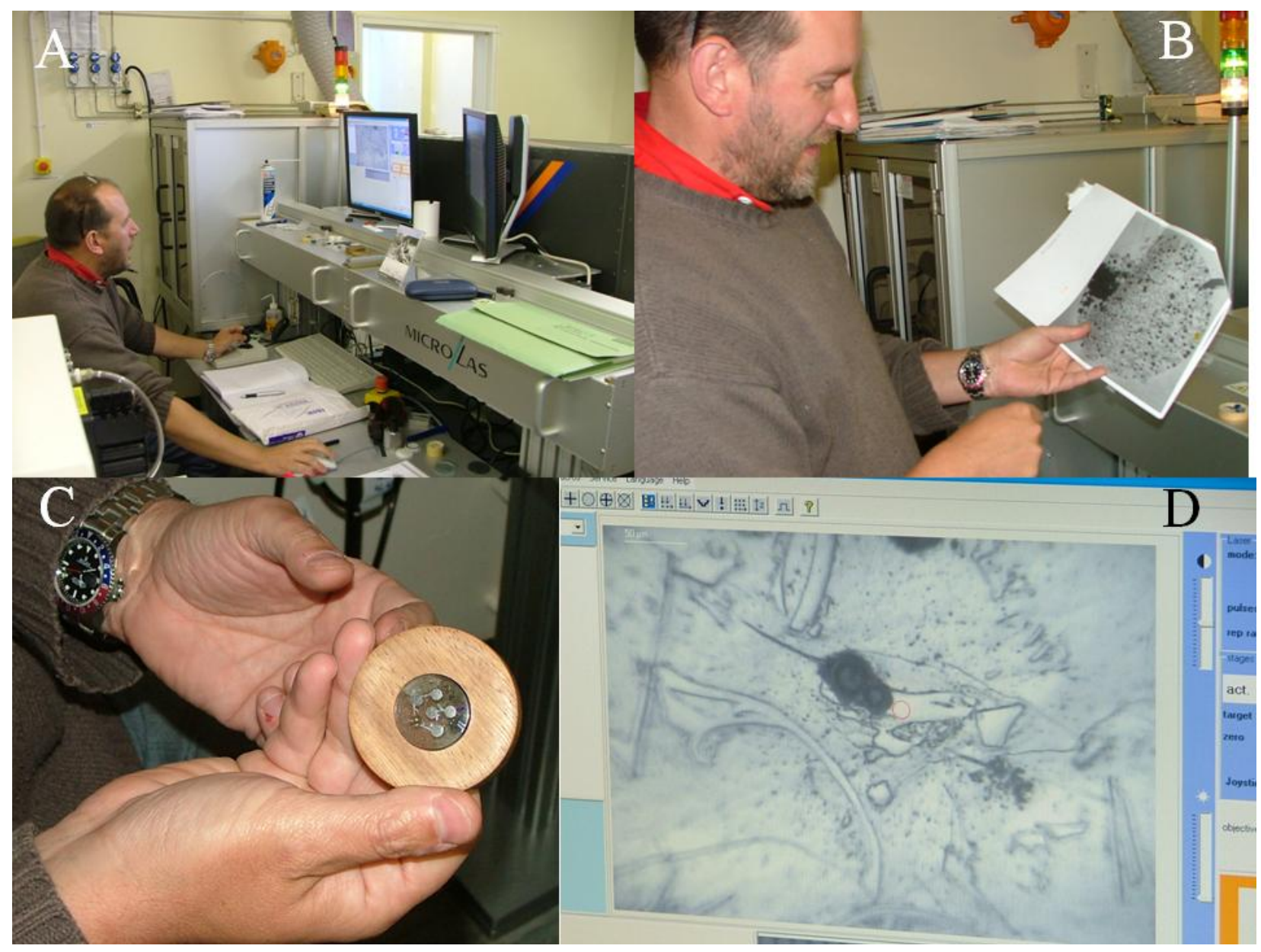

Fig. 18. Illustrations of the LA-ICPMS system. A. Part of LA-ICPMS set-up at Aberystwyth University, Wales, U.K. B. Dr Nick Pearce examining annotated image of a sample of polished glass shards that were previously analysed using EPMA partly to obtain an 'internal standard' (usually $\mathrm{Si}$ ) to calibrate trace-element data derived from LA-ICPMS (see text). The exact same grains can be analysed using LA-ICPMS. C. Five samples in mount ready for analysis. D. View of computer screen image showing polished glass shards with small (red) circle marking position of next ablation point on the target shard. Two dark ablation pits from previous analyses on the target shard are evident alongside at left. Note large cuspate (bubble-wall) shard below-left of target shard. Photos: D.J. Lowe

Calibration of analyses in LA-ICPMS requires the knowledge of one element in the sample to act as an internal standard. Pearce et al. (2007) have determined that ideally analyses would be undertaken using both $\mathrm{Si}$ and $\mathrm{Ca}$ as internal standards for different elements, but pointed out that generally low concentrations of $\mathrm{Ca}$ in rhyolitic glasses (often below $1 \mathrm{wt} \%$ ) usually make it unsuitable as an internal standard and hence $\mathrm{Si}$ is normally the first choice. The use of an internal standard accounts for any variation in the amount of ablated material reaching the plasma (the 
'ablation yield') between samples and calibration standards, and any differences in concentration of the internal standard are able to be corrected during the calculation of concentrations (Pearce et al., 2007). There are very few homogeneous trace element standards that can be used for calibration, and most LA-ICPMS analyses are produced from calibrations against the National Institute of Standards and Technology 'Trace Elements in Glass' standard reference materials NIST 610 or NIST 612 (Pearce et al., 2007). These are certified for only eight elements, but working concentrations for over 50 trace elements in each glass were published by Pearce et al. (1997) and these have since been widely adopted (Pearce et al., 2007).

Around 30 trace elements can now be determined from single glass shards $\sim 40 \mu \mathrm{m}$ in diameter in about three minutes (Pearce et al., 2007). Further, research to enable analyses of a full suite of trace elements from glass shards $\sim 20 \mu \mathrm{m}$ in diameter, and partial analyses of shards in the $\sim 10 \mu \mathrm{m}$ - and potentially $\sim 5 \mu \mathrm{m}$-crater range, has now been undertaken (Pearce et al., 2010; Fig. 19). Many elements useful in tephra studies (e.g., $\mathrm{Rb}, \mathrm{Sr}, \mathrm{Zr}, \mathrm{Nb}, \mathrm{REEs}$ ) are well below $1 \mathrm{ppm}$ at spatial resolutions of about $20 \mu \mathrm{m}$. According to Pearce et al. (2010), analyses of glass shards with ablation craters as small as $10 \mu \mathrm{m}$ in diameter provide high quality, essentially problem-free data, but with smaller sizes the physical process of ablation causes elemental fractionation although that is able to be corrected where it is consistent. Such advances in spatial resolution and sensitivity make it possible generally now to fingerprint fine-grained tephra deposits using a full suite of major- and trace-element data, and will greatly extend the range over which geochemical correlation of tephras potentially can be undertaken (Pearce et al., 2010). These sorts of analyses also provide key information about the magmatic origins, and thus likely source volcanoes of each unit, as well as providing essential data to evaluate magma evolution associated with pyroclastic eruptions (Nairn et al., 2004; Pearce et al., 2008b). 


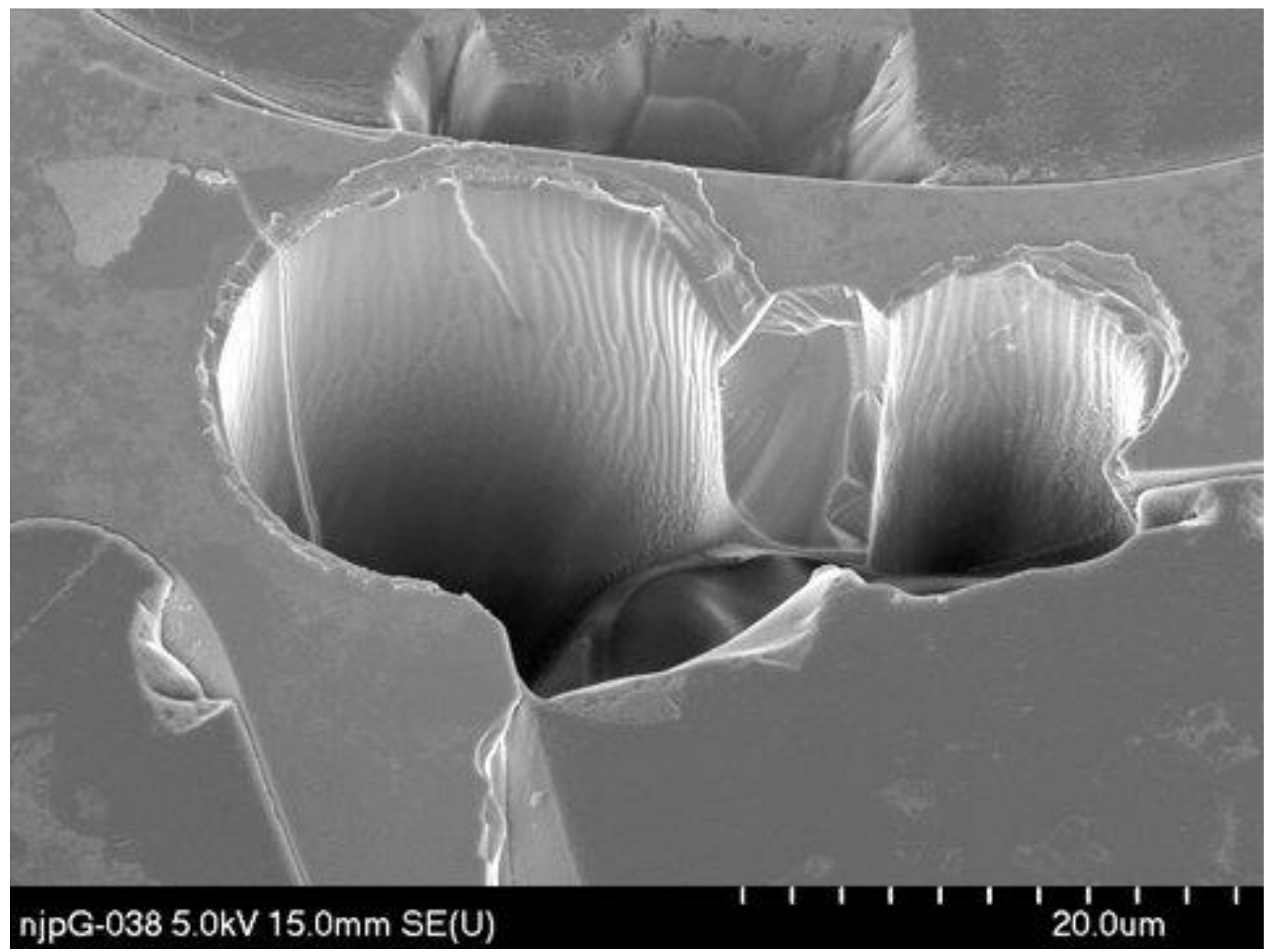

Fig. 19. Laser-induced 'craters', $\sim 20 \mu \mathrm{m}$ and $\sim 10 \mu \mathrm{m}$ in diameter, in a glass shard derived from the Minoan eruption of Santorini, Greece. The craters were formed during LA-ICPMS analysis at Aberystwyth University using a Coherent MicroLas ArF2 Excimer laser ablation system operating at $193 \mathrm{~nm}$ during a 20-second acquisition (laser energy $10 \mathrm{~J} \mathrm{~cm}^{-2}$ firing at $5 \mathrm{~Hz}$ ) (see Pearce et al., 2010). Photo: N.J.G. Pearce.

As well as providing petrological insight, the LA-ICPMS method is probably most useful for separating beds that are not readily distinguishable using major-element chemistry (Pearce et al., 2004a, 2007; Westgate et al., 2008; Kuehn et al., 2009; Brendryen et al., 2010) (although it is noted that some tephras may have very similar trace element and REE glass compositions as well as identical major elements: Simon Blockley pers. comm., 2010). For example, glass shards from the $16^{\text {th }}$ Century BC Minoan eruption of Santorini (also known as Thera), Greece, and the $1645 \pm$ $4 \mathrm{BC}$ eruption of Aniakchak, Alaska, although seemingly quite similar in terms of most major elements, were analysed using LA-ICPMS, the ion (micro)probe, and solution ICPMS (Fig. 20). 
Results from all three methods were very similar (see also Knott et al., 2007), and the Minoan glass clearly differs from that of Aniakchak (Fig. 20).
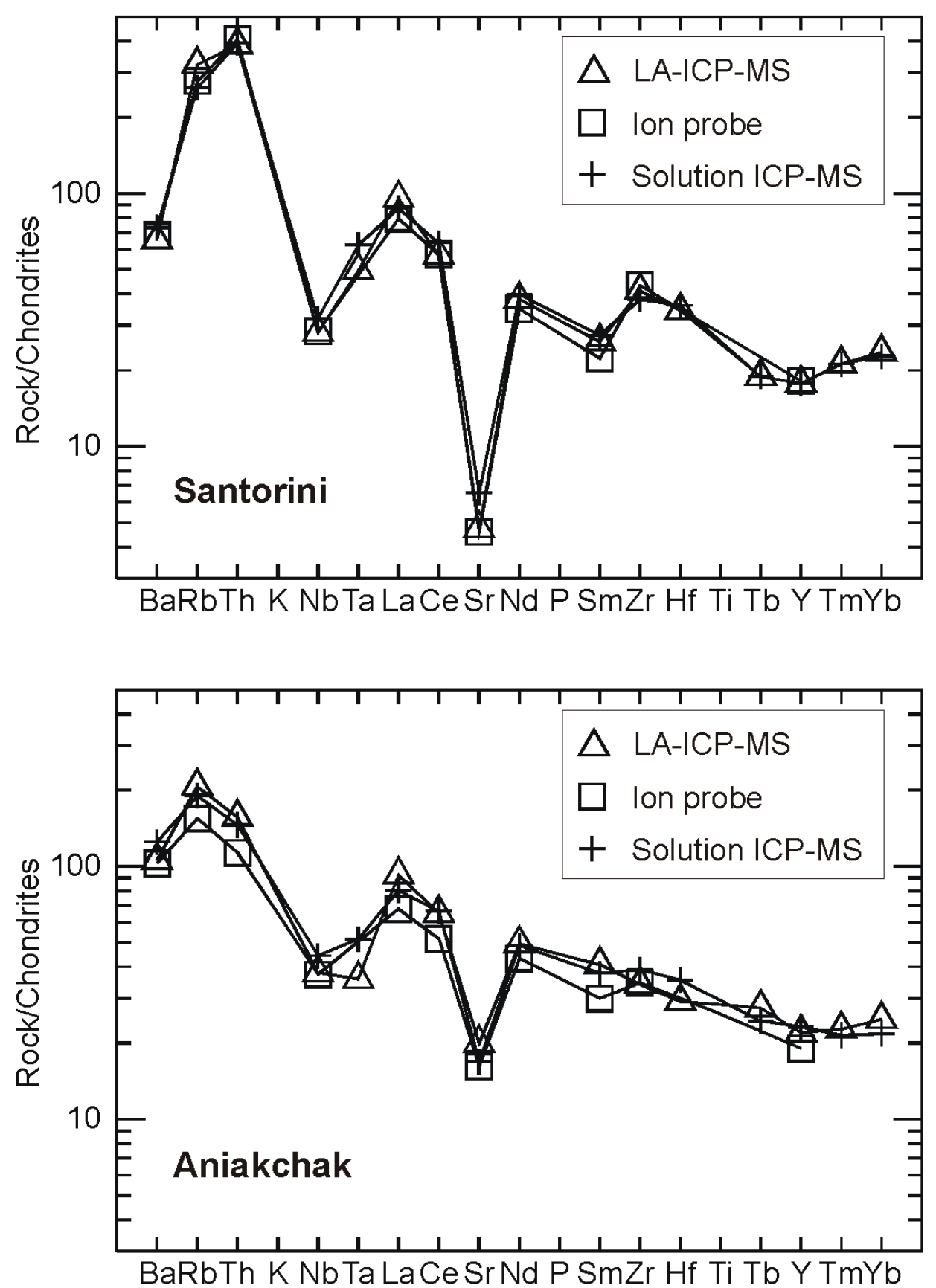

Fig. 20. Comparison of LA-ICPMS, ion probe, and solution ICPMS analyses on glass shards from $16^{\text {th }}$ Century BC Minoan eruption of Santorini, Greece (Fig. 19), and $1645 \pm 4$ BC eruption of Aniakchak, Alaska (from Pearce et al., 2007). Analyses from all three methods are very similar, and the Minoan glass clearly differs from that of Aniakchak (see Pearce et al., 2004b; Denton and Pearce, 2008). Both LA-ICPMS and ion probe data are averages of analyses of individual glass shards: LA-ICPMS Santorini $n=56$, Aniakchak $n=26$; ion probe Santorini $n=$ 14 , Aniakchak $n=12$. For solution ICPMS, $0.5 \mathrm{~g}$ glass separates were analysed. Data normalised to chondritic abundances. 
These findings have implications for the identification of glass shards in the Greenland GRIP ice core that were originally correlated with eruptives from the Santorini eruption by Hammer et al. (2003). Analyses by Pearce et al. (2004b, 2007), such as in Fig. 20, showed that that there were significant differences between the concentrations of $\mathrm{SiO}_{2}, \mathrm{TiO}_{2}, \mathrm{MgO}, \mathrm{Ba}, \mathrm{Sr}$, $\mathrm{Nb}$, and light REEs in the ice-core glass and the Santorini glass, meaning that they could not be correlatives, and that the Aniakchak eruption instead was the most likely source of the glass in the GRIP ice core (see also Keenan, 2003). The implication of this miscorrelation with regard to age modelling undertaken by Vinther et al. (2008) in GRIP using the misidentified 'Santorini' tephra as a tie point was discussed by Denton and Pearce (2008). The newly-established occurrence of Aniakchak tephra in the GRIP ice core provided a precise date of $1645 \mathrm{BC}$ for its eruption (Pearce et al., 2004b).

The main advantage of a single-grain (rather than bulk) technique is that it allows mixed populations to be identified (such mixing arising from magmatic or volcanic eruption processes, or from post-depositional blending of thin tephras in soil-forming environments or from the dissemination of glass shards in peat or lake or marine sediments, or from cryogenic processes e.g., Gehrels et al., 2006; Kristjánsdóttir et al., 2007; Froese et al., 2009). REEs, because of their resistance to weathering and immobility, are also potentially useful where other elements may have been partially lost through hydrolysis during weathering that may have occurred (Saminger et al., 2000; Jordan et al., 2006).

Analyses by ion microprobe (secondary ionization mass spectrometry, SIMS) are also now being undertaken (Begét and Keskinen, 2003; Pearce et al., 2007; Denton and Pearce, 2008; Charlier and Wilson, 2010). Although less readily available than LA-ICPMS systems, more expensive, and slower ( 30 elements can be analysed in about 30 minutes), the ion probe has an advantage in that it uses sputtering rather than ablation to remove sample material into the mass spectrometer. Sputtering (where only a small fraction of the surface of the sample is ionized) causes less damage to very fine shards $(5-10 \mu \mathrm{m})$ such as those recovered from the GRIP ice core 
which, mounted on micropore filters, currently would be practically impossible to analyse by LAICPMS (Pearce et al., 2007).

\subsection{Sr, $\mathrm{Nd}$, and $\mathrm{Pb}$ isotope analyses}

Relatively few analyses of strontium or neodymium isotopes $\left({ }^{87} \mathrm{Sr} /{ }^{86} \mathrm{Sr},{ }^{143} \mathrm{Nd} /{ }^{144} \mathrm{Nd}\right)$ in pumice or glass, using nuclide single collector or multi-collector mass spectrometry, have been undertaken thus far in tephra correlation studies, one exception being the initial Nd-based work of Hart et al. (1992). Analyses have tended to be undertaken (typically on pumices) mainly to help explain magmatic processes (e.g., Arakawa et al., 1998; Sutton et al., 2000; Schmitz and Smith, 2004; Snyder et al., 2004). Sr isotopes were assayed on glass shards in two of the late Quaternary Taupo-derived tephras studied by Sutton et al. (2000). In Antarctica, Basile et al. (2001) used Sr and $\mathrm{Nd}$ isotopes, together with major- and trace-element data, of glass from 15 visible tephras in the Vostok core to identify their sources (Antarctic Peninsula, West Antarctica, southern South America, South Sandwich Islands) and to help model past atmospheric circulation processes. A more recent example involving the specific analysis of glass from a tephra to help identify its source is that of Westgate et al. (2008) where provisional Sr isotope analysis enabled the likely origin of one of the Sheep Creek tephras (SCt-F) to be identified as Mt Drum (Fig. 21). Similarly, Roulleau et al. (2009) used Nd and Sr isotopic composition, together with trace element data, to re-identify source volcanoes for two mid-Quaternary tephras (T32, T21d) at Piànico in Italy that previously had controversial origins and ages (cf. Brauer et al., 2007; Pinti et al., 2007): tephra T32 was derived from Sabatini Mountains in the northern Roman Magmatic Province (ca. 780-800 ka) and tephra T21d from Puy de Sancy volcano, Massif Central, France (ca. 790-710 ka) (glass from T21d and bulk material from T32 were analysed). 


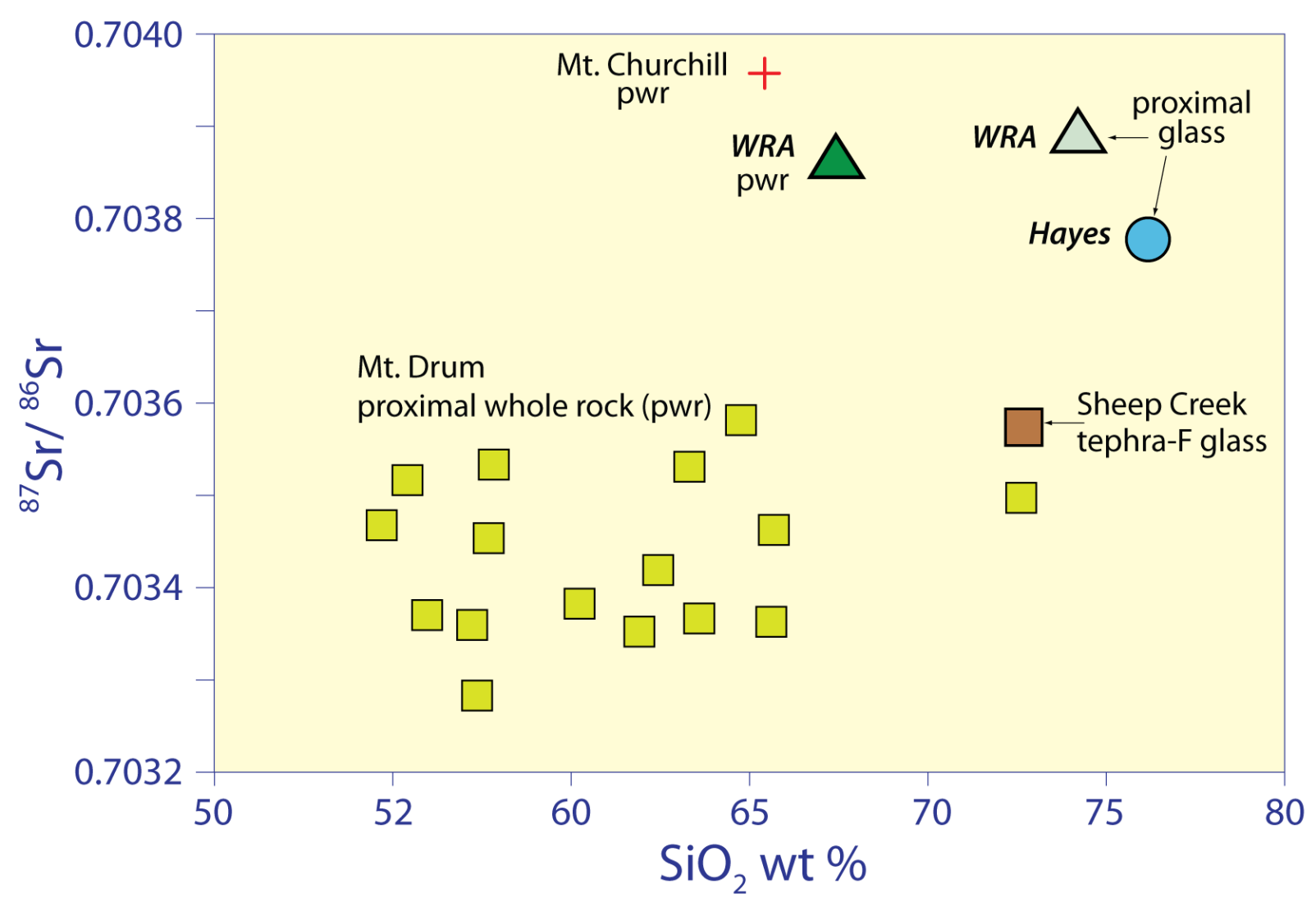

Fig. 21. ${ }^{87} \mathrm{Sr} /{ }^{86} \mathrm{Sr}$ values plotted against $\mathrm{SiO}_{2}$ for whole-rock samples from Mt Drum, Mt Churchill, and Hayes volcano, and glass shards from tephra samples of Sheep Creek tephra-F (SCt-F), White River Ash (WRA), and proximal pumice from Hayes volcano, suggesting that SCt-F was derived from Mt Drum rather than Mt Churchill or Hayes volcanoes (after Westgate et al., 2008).

In South America, Stern (2008) used rubidium and $\mathrm{Sr}$ isoptopic ratios $\left({ }^{87} \mathrm{Sr} /{ }^{86} \mathrm{Sr}\right)$, and other data, on whole rock, pumice, and glass shards to distinguish different source volcanoes for regionally widespread Holocene tephras in southern Patagonia, the sources being Mt Burney, Reclus, Aguilera, and Hudson. In northern New Zealand, Nd-Sr-Pb isotopic compositions of pumice glasses from two eruptives, the Rotoiti/Rotoehu and Earthquake Flat pyroclastic deposits, which were erupted at virtually the same time, showed subtle but distinct differences in the two magmas, hence suggesting there was no direct petrogenetic relationship between them (Schmitz and Smith, 2004). Previous work on the origins of these eruptives had been petrologically equivocal (see also Shane et al., 2005). 
Exploratory research using $\mathrm{Pb}$ isotopes of single glass shards $\left({ }^{207} \mathrm{~Pb} /{ }^{208} \mathrm{~Pb},{ }^{206} \mathrm{~Pb} /{ }^{208} \mathrm{~Pb}\right)$, acquired using LA-ICPMS, as a means of provenance detection for distal tephra beds, was reported by Westgate et al. (2010). They demonstrated that some distal rhyolitic tephra beds in Montana and Saskatchewan were derived from Yellowstone calderas.

\subsection{Fingerprinting strongly-weathered tephras}

The characterization and fingerprinting of strongly-weathered tephra beds (e.g., see Fig. 4A) is difficult because many (sometimes almost all) primary minerals and volcanic glass shards have been dissolved and replaced with secondary minerals including various clays (e.g., see Lowe, 1986b; Churchman and Lowe, in press). Consequently, a volcanic source cannot be established because the compositions of the inherent primary mineral constituents or glass required to obtain a magmatic signature to facilitate correlation are not normally obtainable. However, in favourable circumstances where various resistant primary minerals have persisted (typically in only small quantities), correlations can be made via geochronology by obtaining fission-track ages on sparse zircons (for example) or through magnetopolarity measurements as exemplified by a New Zealand study of weathered Quaternary-aged beds undertaken by Lowe et al. (2001). In other situations, correlations can be made through geochemical analysis of Fe-Ti oxides or glass preserved within quartz grains (so-called 'melt inclusions'), or of some other phase such as apatite or biotite, as illustrated in the following examples.

In Japan, Suzuki (2008), used titanomagnetite compositions, obtained by EPMA, to successfully characterize and correlate extremely weathered, clay-rich tephra-fall and pyroclastic flow deposits aged 0.6 Ma on Kanto Plain, central Honshu. Schmitz and Smith (2004) showed from their study of ca. $61 \mathrm{cal} \mathrm{ka} \mathrm{BP} \mathrm{Rotoiti/Rotoehu} \mathrm{eruptives} \mathrm{that} \mathrm{the} \mathrm{compositions} \mathrm{of} \mathrm{most} \mathrm{glass}$ inclusions (in quartz) overlapped those of pumice glass representing the liquid phase in the magma prior to eruption, implying that such melt inclusions represented a viable tool for 
fingerprinting. Shane et al. (2005), working on the same sequence, similarly found that two populations of glass inclusions in quartz mirrored those of the equivalent matrix glasses.

Earlier, a key finding arose from the earlier benchmark study on older (pre-Quaternary) clay beds by Delano et al. (1995). They demonstrated that fresh glass sealed within host quartz crystals within Ordivician K-bentonites, the weathered remnants of tephras derived probably from large-volume super-eruptions in eastern USA ca. $450 \mathrm{Ma}$, was able to be analyzed using EPMA to determine major-element fingerprints for correlation between three outcrops. More recently, Borisova et al. (2008) were successful in analysing melt inclusions hosted in quartz grains in Pinatubo eruptives for trace elements using LA-ICPMS. However, a comparison by Nairn et al. (2004) of analyses of major elements of glass melt inclusions (in quartz) with those of associated matrix glass in ca. 1314 AD Kaharoa tephras showed some differences, the melt inclusion glass having lower $\mathrm{K}_{2} \mathrm{O} / \mathrm{CaO}$ ratios. In this case, the authors suggested that the quartz crystallised in a melt that subsequently changed composition before quenching by eruption.

Samson et al. (1995) used trace element and Sr isotopic analyses of apatite crystals obtained within clay-rich Ordivician K-bentonites in eastern USA, the Sr isotope compositions proving to be the most diagnostic parameter for distinguishing the bentonite beds. Haynes et al. (1995) analysed biotite phenocrysts using EPMA in certain K-bentonite beds in both USA and Sweden, and suggested that the purported trans-Atlantic correlation of the beds was untenable. Huff (2008), however, used more detailed biotite geochemistry to show that the (weathered) bentonitic tephra beds in question represented separate but simultaneous episodes of explosive volcanism, with some beds possibly being derived from the same eruption.

\section{Databases and software-based correlational aid}

\subsection{Databases}


In attempting to match a tephra to a source volcano, or to compare the properties of a tephra layer at one locality with those of a layer at another to affect their correlation, some prior information is required (derived from field or laboratory observations) in order to compare 'unknown' with 'known', as evident in the previous sections of this paper and as noted by Tryon et al. (2008). As the discipline of tephrochronology has developed, publications of stratigraphic and compositional and age data have emerged on a local or regional basis, and these have been used as the essential prior information to facilitate new correlations. In some instances, data or understanding are only in the form of tacet knowledge, however. Hence it is becoming clear that the compilation of local and regional information pertaining to tephras into appropriate databases is an important next step for various reasons including coping with increasing amounts of information and with increasing complexity (see Newton et al., 2007). Such databases must be centred on regions in the first instance. As noted by Newton et al. (2007), constructing databases can be a key step in the actual research process: they are not simply passive repositories of data because the ways in which they are conceived, designed, and developed can have significant impacts on research directions. The development or expansion of databases is a specific objective of the INTREPID project.

Several databases are currently in existence and their expansion into more comprehensive packages, and the development of new databases, is a big undertaking. Even at the single volcano level (especially andesitic), accurate datasets are inherently difficult to compile even if one or more well-dated eruption records are available (Turner et al., 2009): a single record typically under-represents the eruption frequency, while combining two or more records may result in an over-representation. Using two lake-core records containing mainly andesitic tephra layers in an overlapping time-frame, Turner et al. (2009) showed how analyses of titanomagnetite microinclusions, in combination with age data and stratigraphy, could be used (by merging datasets) to construct an integrated volcanic record pertaining to Egmont/Taranki volcano in New Zealand. 
In Japan, Suzuki et al. (2010) acknowledged the challenge of database construction and have adopted a twin-pronged approach. Firstly, a record of tephra properties, both geographical and volcanological (name, source, age, mode of eruption and emplacement, volume, distribution, VEI, and type locality) and compositional (mineralogy, geochemistry and other properties), is being constructed for 360 Quaternary tephras in Japan. These properties are searchable using File-Maker Pro when an 'unknown' tephra is to be correlated. Secondly, the distributions of the tephras (as isopach maps) are being recorded as layers in an Arc GIS system, and these layers are searchable (e.g., by Quaternarists, archaeologists, etc) to help establish if a tephra potentially has been deposited in a certain area. Future developments include the merging of these two databases into an open-access website (Suzuki et al., 2010).

\subsection{Software-based correlational aid}

A very useful data analysis and graphics package for igneous petrology, known as Igpet and developed by Michael J. Carr (Rutgers University, USA), can provide near-instant plots of all elements obtained by geochemical analysis, enabling researchers to visualise potential matches or non-matches of glass (or mineral) analyses in a few seconds (John Westgate pers. comm., 2010). Igpet has a simple data format with easy transfer of data to and from Excel files (Carr, 2010).

\section{Statistical techniques to aid correlation}

\subsection{Numerical and statistical techniques}

Numerical correlation techniques involving similarity coefficients (SC) and coefficients of variation $(\mathrm{CV})$ to compare geochemical data to facilitate correlation have been used for more than three decades, and are still effective in many tephrostratigraphic studies today (e.g., Kuehn and 
Foit, 2006; Knott et al., 2007; Xia et al., 2007; Aoki, 2008; Lakeman et al., 2008; Tryon et al., 2008; Paczek et al., 2009; Brendryen et al., 2010). Populations can be clustered into dendrograms according to geochemical similarity based on SCs, as undertaken by Bryndryen et al. (2010) using a single linkage (nearest neighbour) protocol via software known as PAST (Hammer et al., 2001). However, the SC cut-off point for correlatives is subjective and varies from around 0.92 in some studies (the lower cut-off limited recommended by Froggatt, 1992) to 0.96 in others (an SC of 1.00 indicates that two sets of analyses are identical for all elements). There is no consensus as to the optimum specific elements for SC calculations (Froggatt, 1992; Stokes et al., 1992; Hillenbrand et al., 2008). Consequently, various multivariate statistical methods have been applied including Euclidian distance analysis (which involves analysis of means), statistical distance analysis (which involves analysis of means and standard deviations), cluster analysis, $t$ test comparisons of means, discriminant function analysis (DFA), and principal components analysis (PCA) (Preece et al., 2000, in press; Keenan, 2003; Pollar et al., 2006; Kurbatov et al., 2006; Lowe et al., 2007; Pearce et al., 2007, 2008a; Hillenbrand et al., 2008; Turner et al., 2009). Hammond and Ward (2001) used a non-hierarchical method of cluster analysis, fuzzy-k means. Its application to the major-element glass analyses (means) of 76 rhyolitic tephras from New Zealand resulted in five fuzzy groups. Scudder et al. (2009) used Q-mode factor analysis and multiple linear regressions, together with XRF-based geochemical analysis, to identify and quantify the abundances of dispersed ash within marine sediments from ODP Site 1149 in the northwest Pacific Ocean near Japan. Three sources of non-biogenic sediment at the site were found to be dacitic ash from the Ryukyu Arc, basaltic ash from the Izu-Bonin frontal arc system, and loess from China (Scudder et al., 2009).

The use of analysis of variance (ANOVA) by Hamann et al. (2010) on fractal dimension values of glass-shard morphometry to affect correlation of an early Holocene tephra (S1) in the eastern meditteranean was reported above (Section 6.2). Tryon et al. (in press) were the first to apply multivariate analysis of variance (MANOVA) to the statistical correlation of tephras. They 
initially examined sample equivalence by PCA, a technique used widely in disciplines such as palaeoecology, and tested it using MANOVA. PCA is used to visualize the distribution of samples in a low-dimensional space, with MANOVA and post hoc Hotelling's T2 used to determine if geochemical centroids of different tephra samples are significantly different. This approach provides a conservative estimate of correlations, and canonical ordination, mathematically designed to maximize differences among groups, is computationally similar to DFA (Tryon et al., in press). Results of the one-way MANOVA indicated that there were significant differences in the geochemical composition of different samples (tephras) in the total sample pool examined by Tryon et al. (in press), suggesting that it was highly unlikely that all sampled tephra deposits were derived from a single eruption $(p<0.0001$ for Wilk's lambda, Pillai’s trace, Hotelling-Lawley trace, and Roy's greatest root), confirming stratigraphic observations of multiple depositional events.

An example of a tephra correlation study involving the application of both similarity coefficient and Euclidean distance parameters, representing similarity and distance between two vectors (two tephra samples), respectively, was that of Xia et al. (2007). In other cases, cluster analysis has been used by Preece et al. (2000, in press) and Jordan et al. (2006) to help correlate tephras. Such analysis derives a distance matrix from overall differences in the compositions of samples. Preece et al. (2000) used Ward minimum variance linkages in their study of type I and type II tephra beds (derived from different source volcanoes, noted in Section 6.2) in the Yukon Territory, Canada (Fig. 22). Their hierarchical cluster analysis enabled 41 samples to be matched to one of 12 distinct beds, 11 of which are shown in Fig. 22. A similar approach, built partly on use of the statistical distance measure of Perkins et al. $(1995,1998)$ for major elements and the Euclidian distance measure for trace elements, was documented in detail by Preece et al. (in press). 

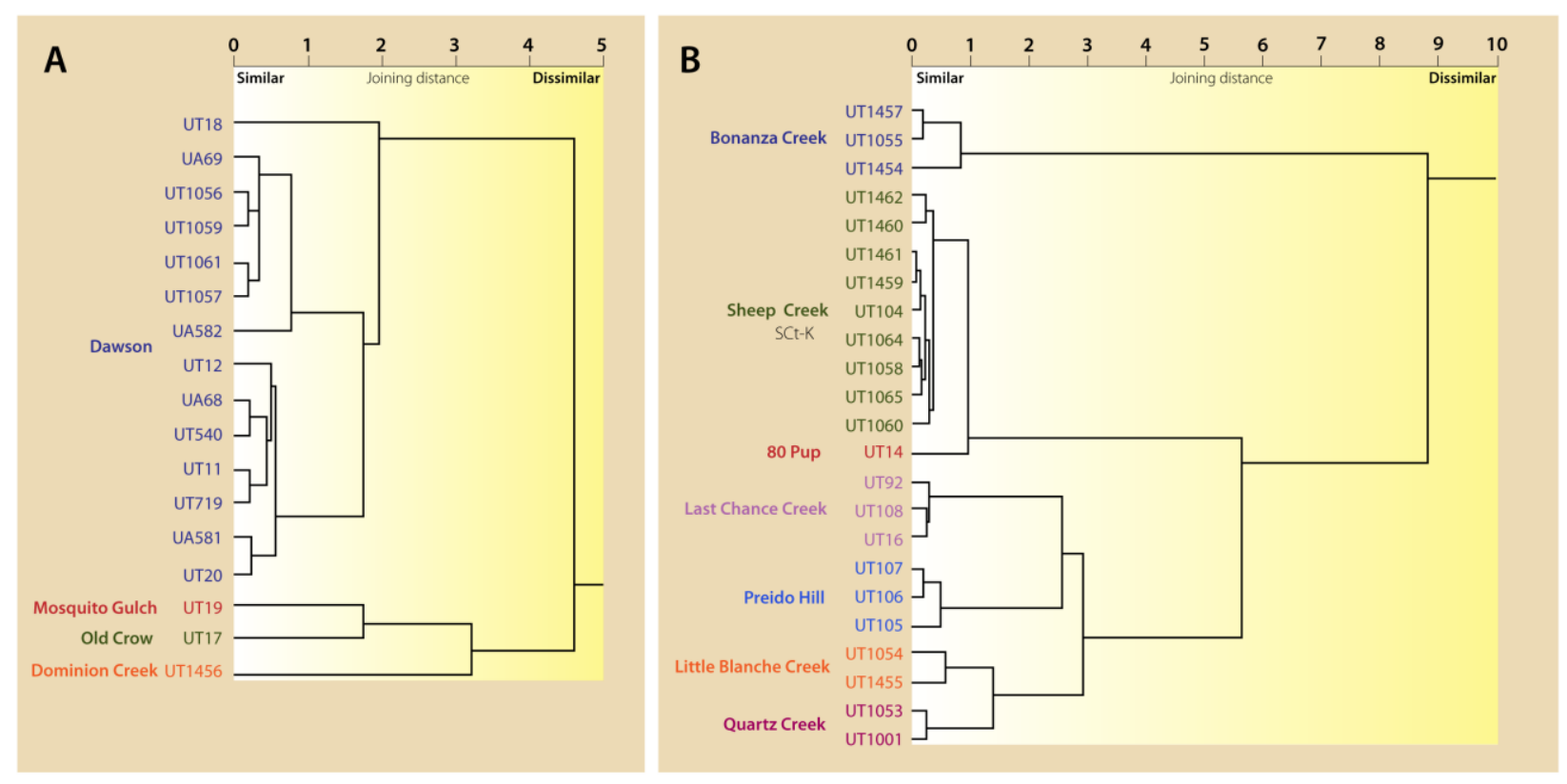

Fig. 22. Cluster analysis of two sets of tephras, Type I and Type II, in central Yukon, showing their degree of similarity/dissimilarity based on the joining distance: samples are most similar where the horizontal lines are at a minimum. Adjacent nearest neighbours in the clusters were assigned to the same tephra bed if they clustered in the same group, had the same trace element and petrographic (mineralogical) characteristics, and compatible stratigraphic positions (after Preece et al., 2000). A. Four Type-I tephra beds derived from vents in the Aleutian arc-Alaskan Peninsula region. B. Seven Type-II tephra beds derived from vents in the Wrangell volcanic field or Hayes volcano.

Further development of these and other multivariate techniques to improve their systematic application forms a core activity for future tephrochronologists (see Pollard et al., 2006; Denton and Pearce, 2008; Pearce et al., 2008a). Applications in other disciplines may additionally be relevant to tephrochronology. For example, erosion studies that attempt to determine the uniqueness of sediment sources ('sediment fingerprinting') include use of the Kruskal-Wallis Htest, the Mann-Whitney U-test (where only two sources are being analysed), and the Tukey test (Davis and Fox, 2009). The former two tests do not assume that data are normally distributed, whereas the Tukey test assumes a normal sampling distribution (Davis and Fox, 2009). 


\subsection{Discriminant function analysis (DFA)}

Canonical DFA is a statistical technique related to principal component analysis that reduces the dimensionality of data (such as compositional analyses) with a large number of independent variables (Cronin et al., 1997). It produces a small number of linear combinations of the quantitative variables which best discriminate pre-defined groups of observations or analyses. Consequently, instead of working with up to 10 oxide analyses of glass, for example, to discriminate groups of samples, one or two canonical variables contain the information. A reference set of analyses with pre-defined groupings must first be set up, and canonical DFA is used to produce a discriminant model that can be used to classify unknown observations or analyses using the reference set (Stokes et al., 1992; Cronin et al., 1997). Before statistical analysis, data are commonly transformed using a log-ratio procedure that ensures data independence (on an oxide-to-oxide basis) and avoids the constant-sum normalization constraints imposed by EPMA of glass or other amorphous phases with variable composition (discussed above) (Stokes and Lowe, 1988; see also Hunt and Hill, 1993). Compositional scores on $d$ oxides are transformed by a log-ratio transformation:

$$
y_{i}=\log \left(x_{i} / x_{d}\right)
$$

where $y_{i}$ denotes the transformed score (i may take values $\left.1 \ldots d-1\right)$ of some raw oxide score $\left(x_{i}\right)$. The logarithm (base 10) term forces a constraint on the datasets in that the component scores must be non-zero (Stokes et al., 1992). Various oxides may be used as the divisor $\left(x_{d}\right)-$ e.g., MgO was used by Cronin et al. (1997).

DFA has several advantages, the most important being that all or most elements (best expressed using the log-ratio transformations) in the analyses are taken into account nonsubjectively, samples are able to be classified (matched) with known probability, and their degree 
of similarity or dissimilarity is reflected in the Mahalanobis multidimensional distance statistic, $D^{2}$ (Borchardt et al., 1971; Beaudoin and King, 1986; Stokes and Lowe, 1988; Stokes et al., 1992). The efficacy of the technique can be tested using iterative or jackknifing procedures to measure classification efficiency (Fig. 23). The successful use of DFA, however, is ultimately directly reliant upon (1) the quality and comprehensiveness of the reference sets against which unknowns are compared, and (2) the recognition of heterogeneity in some glass shard assemblages in tephra units resulting from a single eruptive episode (Charman and Grattan, 1999; Lowe, 2008a). 


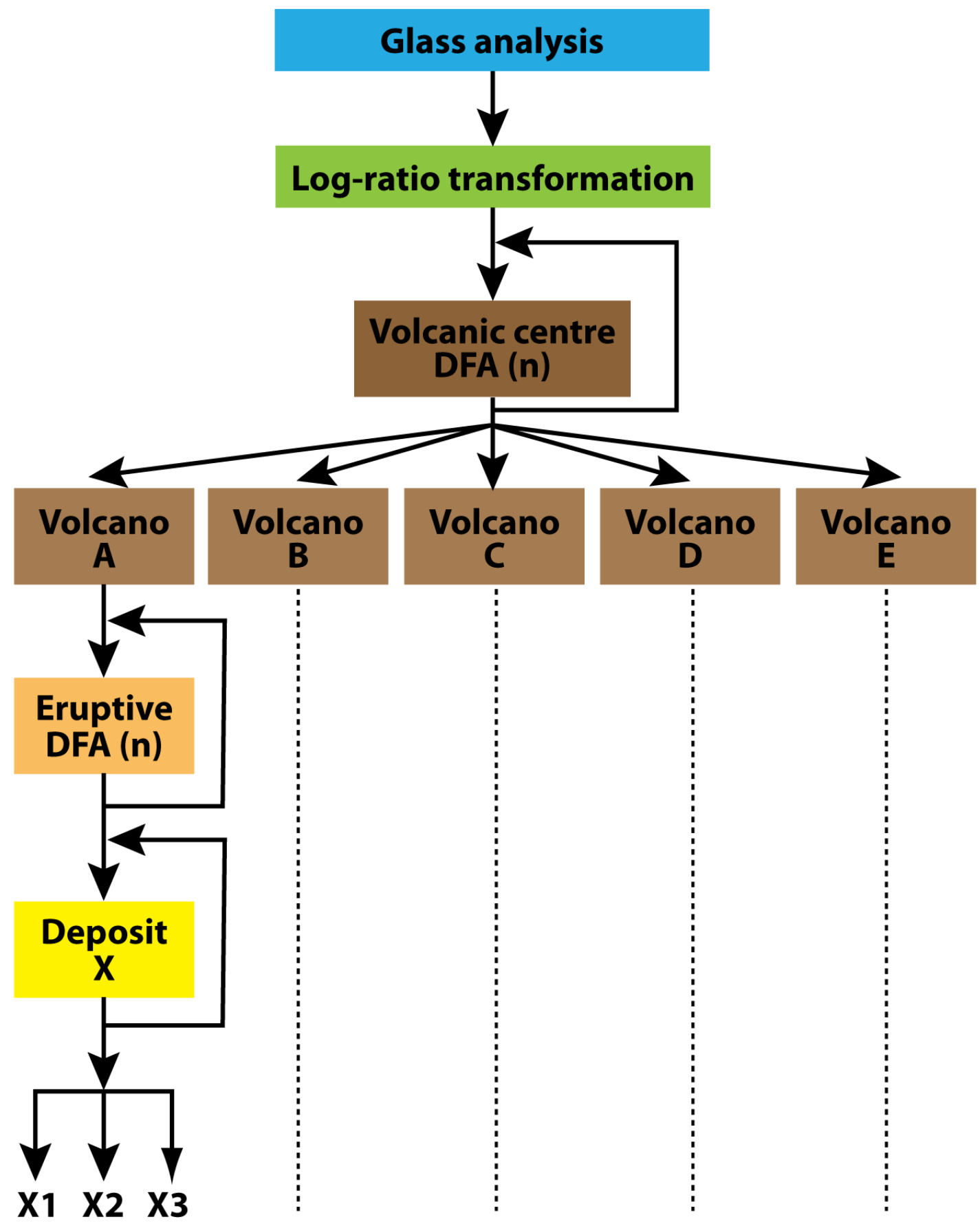

Fig. 23. Flow-chart summarizing DFA models for classifying or correlating tephra deposits using glass composition (similar models would apply for crystal composition). After acquisition and log-ratio transformation of the datasets, the models firstly allow identification of the tephra source volcano and then the particular eruptive(s) associated with that volcano. Deposit X in turn may have multiple components (e.g., X1, X2, X3) representing either different magma types if the tephra is heterogeneous or a mixture of several different tephras forming a composite deposit. The 'return' arrows represent iteration of the DFA using reduced datasets to facilitate greater separation of closely spaced groups (after Stokes et al., 1992). To further reduce complexity, stratigraphically distinct groups of tephras can be divided using one or more regional marker beds (as adopted by Cronin et al., 1997, who divided deposits into two groups, ca. 11.4-27 and ca. 27$61 \mathrm{ka}$ cal BP, using Kawakawa/Oruanui tephra to mark the boundary between them), or by using ages to delimit groups appropriate to the study. 
Examples of the use of DFA in tephra studies include those of Charman and Grattan (1999), Kuehn and Foit (2006), Lowe et al. (2007), Tryon et al. (2009), and Bourne et al. (in press). In New Zealand, DFA has been applied reasonably successfully to studies involving major-element analyses of glass, Fe-Ti oxides, or hornblende for both rhyolitic and andesitic tephras including mixed tephra deposits (Stokes et al., 1992; Shane and Froggatt, 1994; Cronin et al., 1996, 1997; Eden et al., 2001; Turner et al., 2009). An example of how DFA was used, in conjunction with stratigraphic and mineralogical data, to distinguish and correlate rhyolitic tephras aged ca. 27 to $60 \mathrm{ka} \mathrm{cal} \mathrm{BP}$ in central North Island, New Zealand, is shown in Fig. 24 (Cronin et al., 1997). In this study, the tephras were divided into two stratigraphically distinct groups of tephras using a regional marker bed so that two relatively simple discriminant models were developed rather than a single very complex model. From this study, based on seven (logtransformed) major element oxides obtained from the EMP analysis of glass, it is clear that two very widespread tephras such as the Kawakawa/Oruanui and Rotoehu tephras would be unlikely to be misidentified if only one of them were present in a distal section. The relatively high $D^{2}$ value of 64 (Table 3) shows that they are significantly different. Such dissimilarity is evident in the plot in Fig. 24, the least similar (most different) tephra pair being Hauparu and Tihoi tephras with a high $D^{2}$ value of 262. In contrast, the Kawakawa/Oruanui and Okaia tephras, with a low $D^{2}$ value of only 7.3 , are indistinguishable on the basis of glass major element composition (Table 3; Fig. 24). Both were erupted from Taupo volcano within a short period of each other (Fig. 2). 


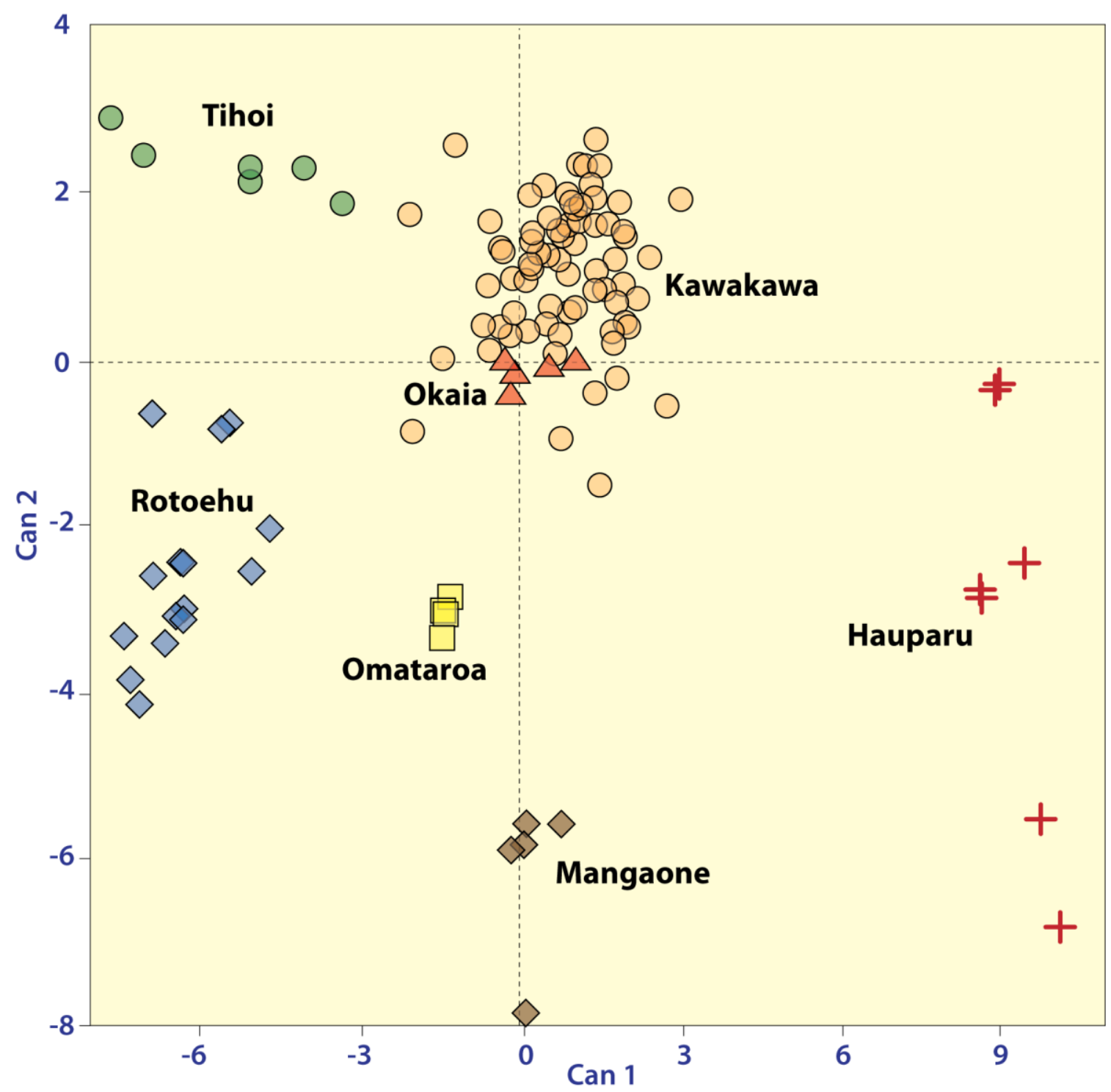

Fig. 24. Example of use of canonical DFA to compare degree of similarity of seven late Quaternary rhyolitic tephras aged from ca. 61 to $27 \mathrm{ka}$ cal BP in central North Island, New Zealand. Glass compositions of each tephra were combined using DFA into the first two canonical variates (Can 1 and Can 2). The distance between groups ( $D^{2}$, given in Table 3$)$ is a direct measure of their multivariate similarity/dissimilarity based on seven major oxides analysed, not just two or three (after Cronin et al., 1997). 


\section{Table 3}

$D^{2}$ values and classification efficiencies of a discriminant function model developed for seven rhyolitic marker tephras in New Zealand aged ca. 27 to ca. 61 ka cal BP (from Cronin et al., 1997). Larger $D^{2}$ values indicate tephra pairs are more dissimilar (i.e., different), smaller values indicate pairs are more similar on the basis of major element compositions of constituent glass shards.

\begin{tabular}{|c|c|c|c|c|c|c|c|}
\hline & $\mathrm{Kk}$ & Oi & Om & $\mathrm{Ma}$ & $\mathrm{Hu}$ & $\mathrm{Ti}$ & $\mathrm{Re}$ \\
\hline \multicolumn{8}{|c|}{$D^{2}$ values between groups } \\
\hline $\mathrm{Kk}$ & - & 7.3 & 25 & 77 & 98 & 45 & 64 \\
\hline Oi & & - & 18 & 59 & 106 & 40 & 61 \\
\hline $\mathrm{Om}$ & & & - & 30 & 123 & 50 & 30 \\
\hline $\mathrm{Ma}$ & & & & - & 126 & 118 & 85 \\
\hline $\mathrm{Hu}$ & & & & & - & 262 & 245 \\
\hline $\mathrm{Ti}$ & & & & & & - & 35 \\
\hline \multicolumn{8}{|c|}{ Percent correctly reclassified by model } \\
\hline & 93 & 100 & 100 & 100 & 100 & 100 & 100 \\
\hline
\end{tabular}

*Tephra names are Kk, Kawakawa or Oruanui; Oi, Okaia; Om, Omataroa (Unit K); Ma, Mangaone (Unit I); Hu, Hauparu (Unit F); Ti, Tihoi; Re, Rotoehu

Insert Table 3 about here

The classification efficiencies of the discriminant model in Fig. 24, determined by reanalysis using a jackknifing procedure, were very high for all of the tephra groups, the lowest value being $93 \%$ for the Kawakawa/Oruanui tephra (Table 3). Step-wise DFA of the analyses indicated that all of the transformed oxides were highly discriminating. The order in which the oxides were chosen (effectively 'weighting') was $\mathrm{K}_{2} \mathrm{O}, \mathrm{FeO}, \mathrm{Al}_{2} \mathrm{O}_{3}, \mathrm{CaO}, \mathrm{TiO}_{2}, \mathrm{SiO}_{2}$, and $\mathrm{Na}_{2} \mathrm{O}$ (Cronin et al., 1997). Many individual tephra layers or groups of tephras in this and other New Zealand studies were thus able to be discriminated with a high-degree of probability (up to $100 \%$ classification efficiency) using either glass or titanomagnetite compositions, but some tephras, very similar compositionally, were less-well discriminated or unidentifiable using major elements alone. 


\section{Developments in dating methods and age modelling for tephrochronometry}

\subsection{Dating tephras directly and indirectly}

Firstly, note that the term 'numerical age' should always be used in preference to the inappropriate misnomer 'absolute age' (Colman et al., 1987). Tephras may be dated directly using primary minerals (such as zircon, hornblende, K-feldspar, biotite, quartz) or glass from within the tephra layer, or indirectly on enclosing or encapsulated material, using a range of methods:

(1) radiometric (e.g., Lacasse and van den Bogaard, 2002; Toms et al., 2004; Toyoda et al., 2006; Baron et al., 2008; Demuro et al., 2008);

(2) incremental (Zillén et al., 2002);

(3) age-equivalence (Lacasse et al., 1998; Wulf et al., 2004; Kristjánsdóttir et al., 2007; Placzek et al., 2009); and

(4) age-modelling of sediment sequences (Shane et al., 2002; de Fontaine et al., 2007; Lowe et al., 2007) (Table 4).

An excellent example of a tephra that has been dated by using multiple methods is that of Pillans et al. (1996). The widespread ca. 340 ka Rangitawa tephra (Fig. 4A) in the New ZealandSouth Pacific region, noted earlier as being the subject of controversy regarding its age, was dated using zircon- and glass-based fission-track analysis, glass-ITPFT analysis, infra-red stimulated luminescence, thermoluminescence, K/Ar and single-crystal laser fusion ${ }^{40} \mathrm{Ar} /{ }^{39} \mathrm{Ar}$ analysis, and orbital tuning estimated via oxygen isotope stratigraphy in deep-sea cores (Pillans et al., 1996; Lowe et al., 2001; Alloway et al., 2007a; Holt et al., 2010). 


\section{Table 4}

Methods used for dating tephras directly or indirectly (after Newnham et al., 1999b; Alloway et al., 2007a).

Main method Applications

Radiometric Radiocarbon dating (radiometric/beta counting, AMS) ${ }^{\mathrm{a}}$, fission-track dating (zircon, glass-ITPFT dating), argon isotopes (K/Ar, $\mathrm{Ar} / \mathrm{Ar}$ including SCLP/F, LIH), luminescence dating (TL, OSL, IRSL), U-series including (U-Th)/He dating and ${ }^{238} \mathrm{U} /{ }^{230}$ Th zircon dating (via SIMS/TIMS), electron spin resonance (ESR), ${ }^{210} \mathrm{~Pb},{ }^{137} \mathrm{Cs},{ }^{3} \mathrm{He}$ and ${ }^{21} \mathrm{Ne}$ surface exposure dating

Incremental

(annually

banded)

Age equivalence

Relative

Historical

Age modelling
Dendrochronology, varve chronology, layering in ice cores (ice sheets/ caps, glaciers)

Magnetopolarity, paleomagnetic secular variation (PSV), orbital (astronomical) tuning, correlation with marine oxygen isotope stages, palynostratigraphy, palaeopedology

Obsidan hydration dating, amino acid racemisation (AAR)

Eye-witness accounts or observations (written, oral)

Various statistical methods including Bayesian-based flexible depositional modelling and wiggle matching, free-shape modelling, periodic time series

${ }^{\mathrm{a}} \mathrm{AMS}$, accelerator mass spectrometry; ITPFT, isothermal-plateau fission track; SCLP/F, single-crystal laser probe or fusion; LIH, laser incremental heating; TL, thermoluminescence; OSL, optically stimulated luminescence; IRSL, infra-red stimulated luminescence; SIMS, secondary ionization mass spectrometry; TIMS, thermal ionization mass spectrometry

For tephras erupted within the past ca. 60,000 cal years, the radiocarbon $\left({ }^{14} \mathrm{C}\right)$ technique remains the most important method for developing pre-historic age models (Alloway et al., 2007a). New applications of U-Th and (U-Th)/He dating on single zircon crystals, however, are now being used to date tephras in this age range, such as on the late Quaternary La Virgen tephra, Baja California (Schmitt et al., 2010). These new ages on La Virgen tephra were consistent with ${ }^{3} \mathrm{He}$ and ${ }^{21} \mathrm{Ne}$ exposure ages on lavas stratigraphically associated with it.

Where suitable (K-rich) minerals are available (e.g., sanidine, anorthoclase), the ${ }^{40} \mathrm{Ar} /{ }^{39} \mathrm{Ar}$ method has been very successful, such as in the Mediterranean region (Ton-That et al., 2001; Lanphere et al., 2007), Germany (van den Bogaard, 1995), western USA (Lanphere et al., 2004; Knott et al., 2007), and Kenya and Ethiopia (Deino and McBrearty, 2002; Deino et al., 2010). In some cases, lavas encapsulating tephras have provided the minerals necessary for the K/Ar or 
Ar/Ar application (Briggs et al., 1989; Wilson et al., 2007; Deino et al., 2010). In another recent study, discrepancies between previous ${ }^{14} \mathrm{C}$ - and ${ }^{40} \mathrm{Ar} /{ }^{39} \mathrm{Ar}$-derived ages on lake sediments and associated tephras in the Mono Basin sequence, California, were reconciled partly using new ${ }^{40} \mathrm{Ar} /{ }^{39} \mathrm{Ar}$ ages obtained on sanidine and biotite crystals, and on obsidian, from three tephras within the sediments (Cassata et al., 2010). Lacasse and van den Bogaard (2002) obtained laser probe ${ }^{40} \mathrm{Ar} /{ }^{39} \mathrm{Ar}$ ages on K-feldspar and biotite phenocrysts of tephras that were erupted from the Jan Mayen volcanic system in the subpolar North Atlantic. The ages were compared with a tuned paleomagnetic age model, and oxygen isotope and ice-rafted debris records, and hence used to refine the time scale of the inception of ice rafting on the Iceland Plateau (ca. 3.3-3.14 Ma).

Other isotopes such as ${ }^{210} \mathrm{~Pb}$ and ${ }^{137} \mathrm{Cs}$ (e.g., Hodgson et al., 1998; Newnham et al., 1998a; Boer et al., 2006; Daga et al., 2008), and varved sequences (e.g., Stihler et al., 1992; Zillén et al., 2002; Katsuta et al., 2007), are also used to provide chronologies for younger sections of sediment cores containing tephras. Dendrochronology (usually in combination with wigglematching) is additionally important for tephrochronometry where circumstances are favourable (Druce, 1966; Hogg et al., 2003, 2009; Sheppard et al., 2009). For example, Nakamura et al. (2007) used ${ }^{14} \mathrm{C}$-based wiggle-matching methods to date wood samples relating to a $10^{\text {th }}$ Century volcanic eruption of Baitoushan volcano in Japan, the results being consistent with dendrochronological and varve-age estimates.

Relative dating methods such as amino acid recemization (e.g., Kimber et al., 1994), obsidian hydration dating (Stevenson et al., 1996), and historical records where available have also been used (Alloway et al., 2007a).

\subsection{Depositional age modelling}

A critically important recent advance in tephrochronometry has been the development of sediment depositional age modelling and wiggle-matching techniques using Bayesian statistical 
frameworks and the internationally-agreed ${ }^{14} \mathrm{C}$ calibration curves (IntCal04 and IntCal09) and other time-series that span earlier time periods (Bronk Ramsey, 2008; Blockley et al., 2008a, 2010). Such modelling provides enhanced and more precise chronologies expressed as probabilities (e.g., Buck et al., 2003; Davies et al., 2004a; Wohlfarth et al., 2006; Bayliss, 2007; Blockley et al., 2008b; Lowe et al., 2008a; Kuehn et al., 2009; Olsen et al., 2010). In New Zealand, 14 late Quaternary tephras preserved in peat at montane Kaipo bog in eastern North Island were dated by Bayesian depositional modelling (similar to wiggle matching) by comparing flexibly their stratigraphic order and all 51 associated ${ }^{14} \mathrm{C}$-age points simultaneously against IntCal04 (Hajdas et al., 2006; Lowe et al., 2008a). The modelling was undertaken using OxCal and Bpeat which both utilise Bayesian statistics (Blaauw et al., 2007; Bronk Ramsey, 2008). As well as using stratigraphic superpositioning to constrain the calibrations, Bpeat uses a piece-wise linear accumulation framework and formal outlier probability analysis. A more recent Bayesianbased method for flexible age-depth modelling is Bacon, which was developed by Blaauw and Christen (submitted for publication). In some cases, wiggle matching sensu stricto in sedimentary depositional contexts can lead to erroneous results, as shown by Blockley et al. (2007b), who recommended that a stepped procedure be used for identifying the most appropriate age model relevant to the underlying assumptions.

Other statistical modelling methods can be applied to generate ages for sedimentary sequences that contain tephras (e.g., Buck and Millard, 2004; Heegaard et al., 2005; Haslett and Parnell, 2008; de Brauwere et al., 2009; Goslar et al., 2009; Blaauw, 2010).

\subsection{Isothermal-plateau fission-track (ITPFT) dating of glass}

For older tephras, a key advance in the past two decades has been the development of the ITPFT method for dating glass reliably. Many tephras previously gave unreliable ages using conventional fission-track methods because of partial annealing or fading of their main 
component, glass, and inaccurate thermal neutron dose determinations (Seward, 1979; Kohn et al., 1992; Alloway et al., 1993). But the ITPFT method corrects for annealing and enables them to be dated accurately (Westgate, 1989; Sandhu et al., 1992, 1993; Westgate et al., 2007). Examples of ITPFT-based tephrochronological applications include the dating of initial loess deposition in Alaska at ca. 3 million years ago (Westgate et al., 1990), dating Quaternary glacioeustatic sedimentary cycles in the Wanganui Basin, New Zealand (Pillans et al., 2005), and dating marine tephra sequences from ocean cores near New Zealand and Japan that test chronologies based on alternative methods (Alloway et al., 2005; Aoki, 2008).

\subsection{Magnetostratigraphy}

Because the ages of geomagnetic polarity transition zones are well known for the Quaternary period, magnetopolarity information provides an independent means of checking numerical ages obtained on tephras by radiometric methods or by orbital tuning (Black et al., 1996; Naish et al., 1998; Westgate et al., 2001; Alloway et al., 2004b, 2007a; Cassata et al., 2010). The geomagnetic polarity sequence registered in sediments encapsulating a tephra thus provides a useful signature for correlation purposes as an age-equivalence dating tool (Verosub, 1981; Rogers and Larson, 1992; Sarna-Wojcicki et al., 1997; Merrill and McFadden, 2005; Deino et al., 2010). Alloway et al. (2007a) highlighted two case studies where the identification of field reversals or polarity events, including the Matuyama-Gauss field reversal (2.6 Ma) and the relatively short-lived Olduvai (1.95-1.79 Ma) or Jaramillo (1.07-0.99 Ma) polarity events, had greatly facilitated the development of a tephrostratigraphic framework - firstly in loess beds in central Alaska (Preece et al., 1999) and secondly in sedimentary basins in the southern North Island of New Zealand (Pillans et al., 1994, 2005; Naish et al., 1996; Shane et al., 1996).

In Japan, magnetic measurements by Hayashida et al. (1996) on widespread tephra-fall deposits and ignimbrites (products of pyroclastic density currents) provided the means both to 
correlate these units and to link the source volcanic area with marine and other sequences over a distance of $\sim 1000$ km (Fig. 25). Correlative co-eruptives, the Imaichi, Azuki, and Ku6C beds, aged ca. 0.9 Ma, all had reversed polarities (relating to the Matuyama period of reversed polarity), whereas another set of correlative co-eruptives, the Yabakei, Pink, and O7 beds, aged ca. $1 \mathrm{Ma}$, all had normal polarities (relating to the Jaramillo event). The magnetopolarities provided useful constraints for tephrostratigraphic correlations made using glass and mineral composition, and the chronological and stratigraphic data relating to the tephra units were in close accord with global sea-level cycles and the astronomically-calibrated geomagnetic polarity time scale (Hayashida et al., 1996).

Palaeomagnetic secular variations (PSV) are changes through time in the components of the magnetic field (declination, inclination, and intensity) (Negrini and Davis, 1992). They provide a means both of correlating and synchronizing sedimentary records containing tephras or cryptotephras, such as those studied by Kristjánsdóttir et al. (2007) from cores MD99-2269 and MD-2322, hence helping with the development of age models. PSV measurements on a core from Lake Omapere in Northland, New Zealand (Fig. 7), enabled an age of ca. 55 ka cal BP to be estimated by Newnham et al. (2004) for Rotoehu ash in the core using palynostratigraphy. The age on the near-basal lake sediments in the core was determined to be ca. $74 \mathrm{ka}$ on the basis of the pollen assemblages identified representing the MOI stage 5a-4 boundary. PSV measurements between this point and the Rotoehu ash near the top of the core indicated a time span of ca. 20,000 years ( \pm ca. 4000 years), and hence the tephra age was calculated at approximately 55 ka. This estimate (with errors) is broadly concordant with a ${ }^{14} \mathrm{C}$-age of ca. $47 \mathrm{ka}{ }^{14} \mathrm{C} \mathrm{BP}$, obtained on lake sediment just below the Rotoehu ash in Lake Omapere, which likely relates to a calendar age earlier than ca. $50 \mathrm{ka}$ cal BP (e.g., Beck et al., 2001; Hughen et al., 2006). It also accords with a climatostratigraphic age of ca. 55-57 ka cal BP derived for Rotoehu ash from its presence on uplifted marine terraces in eastern North Island correlated with MOI stages (Berryman et al., 2000), and with an Ar/Ar age of $61.0 \pm 1.4$ ka obtained from lavas enveloping Rotoehu ash on 
Mayor Island (Wilson et al., 2007). Other age estimates, however, based on various techniques, are considerably younger, being closer to ca. $45 \mathrm{ka}$ cal BP (see Lowe and Hogg, 1995; Lian and Shane, 2000; Santos et al., 2001; Shane et al., 2006).

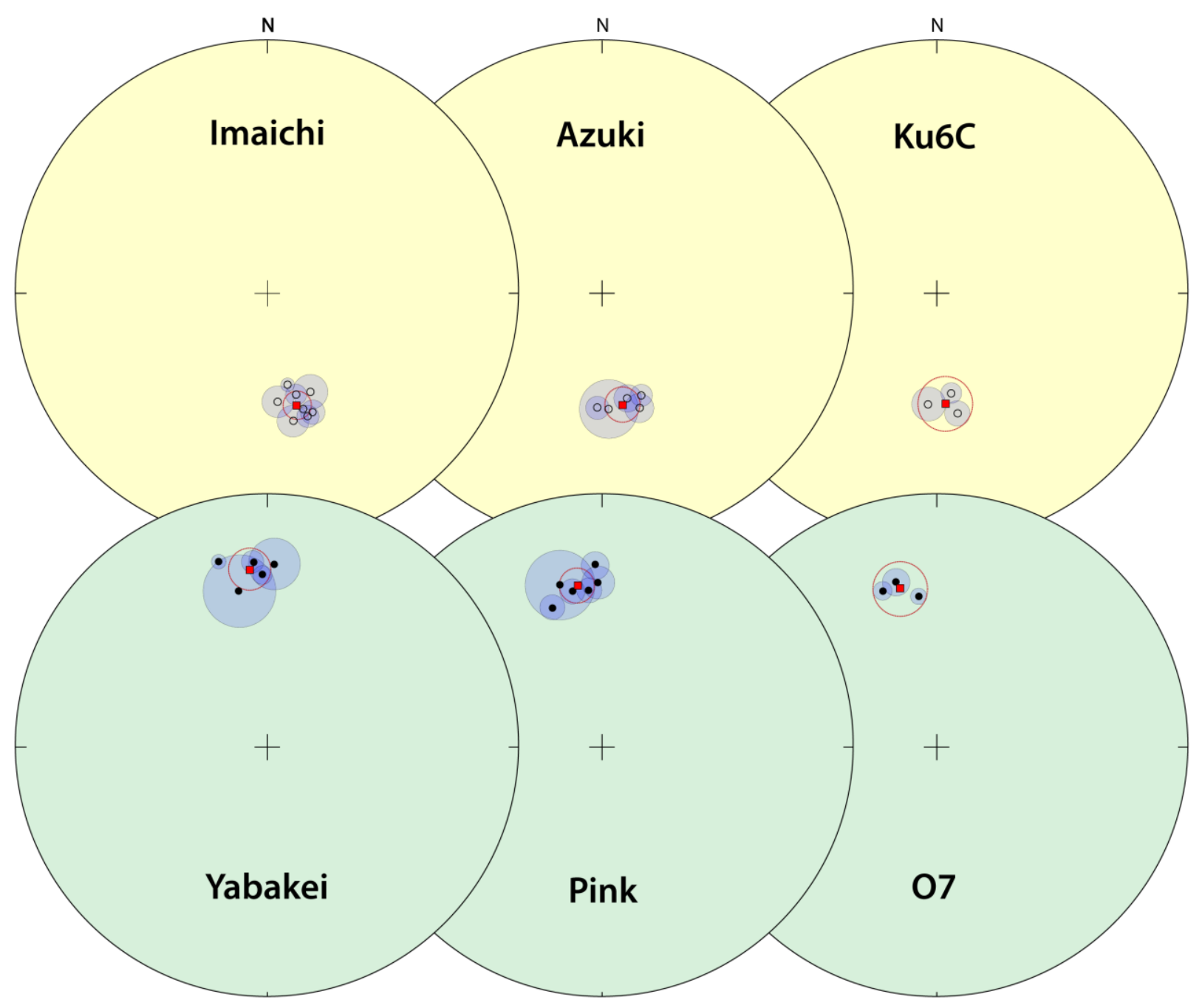

Fig. 25. Equal-area projections of paleomagnetic directions (with $95 \%$ confidence circles) for two sets of co-eruptives in Japan that extend up to $\sim 1000 \mathrm{~km}$ from source: (upper) mean magnetic directions of the Imaichi ignimbrite (Kyushu Island), Azuki tephra (Kinki district) and Ku6C tephra (Boso Peninsula) are all of reversed polarity with slightly easterly declinations; (lower) mean magnetic directions of the Yabakei ignimbrite (Kyushu Island), Pink tephra (Kinki district) and $\mathrm{O} 7$ tephra (Boso Peninsula) are all of normal polarity with slightly westerly declinations (after Hayashida et al., 1996). The identical palaeomagnetic directions for the three tephras in each each group of deposits confirm correlations based on compositional and age data. Open symbols are on the upper hemisphere, solid symbols are on the lower hemisphere, and squares represent the mean direction in each projection. 
In South Australia, palaeomagnetic direction measurements of the mid-Holocene Mt Gambier basaltic eruptives showed that the entire sequence (comprising two main eruption periods) had been erupted over a short time interval because the PSV measurements at the start and end of activity were identical (Barbetti and Sheard, 1981). At the same time, the palaeomagnetic directions differed from those obtained from nearby Mt Schank meaning that the two volcanoes had not erupted contemporaneously, being at least three centuries apart (although it has not yet been determined which erupted first) (Sheard, 1990, 1995; Robertson et al., 1996).

Measurements of magnetic susceptibility and other magnetic parameters such as isothermal remanent magnetization have been used successfully as correlation tools in tephra-related studies (e.g., Palmer and Pillans, 1996; Gonzalez et al., 1999; Newnham et al., 1999b; Xia et al., 2007; Peters et al., 2010; Venuti and Verosub, 2010). Wagner et al. (2008) warned that high magnetic susceptibility values in lake sediments in their European study related to detrital magnetic minerals rather than tephra or cryptotephra layers, however, a finding echoed in part by Veres et al. (2008).

\section{Geochronological applications of tephrochronology}

\subsection{Classical and recent applications}

Tephrochronology provides ages and isochrons for an enormous range of applications in widely diverse disciplines encompassing the sciences, social sciences, and humanities in the Quaternary. For instance, the New Zealand-based tephra review by Froggatt and Lowe (1990) alone has been cited in at least 62 different journals (with 57 being non-New Zealand journals). Applications thus range from what might be regarded as 'classical' including geology, volcanology, geomorphology, pedology, glaciology, palaeoecology, palaeoclimatology, palaeolimnology, and archaeology (e.g., see Lowe, 1990), through to more recent uses relating to 
assessing past atmospheric circulation patterns, palaeoseismology and neotectonism, animal and plant biodiversity, biogeography, molecular biology, and evolution.

Some examples of applications that used tephrochronology to mark or date deposits or events include the following:

(1) chronostratigraphic boundaries or intervals (e.g., MOI stages), or events such as Dansgaard-Oeschger events (Pillans et al., 1993; Newnham et al., 2003, 2007a; Chun et al., 2007; Hillenbrand et al., 2008 ; Veres et al., 2008);

(2) tectonic and climatic controls on landscape evolution (Berryman et al., 2000; Clague et al., 2003; Litchfield and Berryman, 2005);

(3) palaeoseismicity (de Lange and Lowe, 1990; Nicol et al., 2006; Berryman et al., 2008);

(4) sedimentary or volcanic successions (Shane et al., 2002, 2006; Wohlfarth et al., 2006);

(5) glacial processes and ice-cap response to climate change (Kirkbride and Dugmore, 2006, 2008);

(6) accelerated soil erosion (Page and Trustrum, 1997; Dugmore et al., 2009);

(7) past atmospheric circulation patterns (Lacasse et al., 1998; Basile et al., 2001; Lacasse, 2001; Lacasse and van den Bogaard, 2002; Narcisi et al., 2005, 2010);

(8) regional paleoenvironmental reconstructions (Newnham et al., 1995a; Alloway et al., 2007b; Froese et al., 2009; Reyes et al., 2010);

(9) storm frequency and magnitude in the Holocene (Page et al., 2010); and

(10) carbon dioxide release during deglaciation (Rose et al., 2010).

Another rapidly growing development has been the enhanced use of tephrochronology to affect more precise correlations between marine, ice-core, and terrestrial records (as noted in the introduction). This application holds the key to testing the reliability of high-precision correlations between sequences and current theories about the degree of synchroneity of climate change at regional to global scales - provided the tephra correlations are sound. Numerous studies in the past few decades have utilized this unique chronostratigraphic capability (e.g., 
Knox, 1993), but in recent times tephrochronology has become a critical 'player' for international palaeoenvironmental programmes such as the INTIMATE projects in both Northern and Southern hemispheres (Turney et al., 2006; Alloway et al., 2007b; Lowe et al., 2008a; Lowe et al., 2008b). Some caveats are required, however. For example, some of the difficulties and uncertainties that may arise in attempts to use tephras to test the synchroneity of past climatic change events over wide areas were reported and discussed by Austin and Abbott (2010), Blaauw et al. (2010), and Blaauw and Wohlfarth (2010). In this instance, the complexity arising from the occurrence of multiple, closely spaced eruptives (the North Atlantic Ash Zone II) has led to uncertainty. Further case studies are outlined below.

Rasmussen et al. (2008) correlated the NGRIP, GRIP, and GISP2 ice-core records across MOI stage 2 using mainly volcanic 'signatures' (such as sulphate layers or ECMs) - but not yet glass-shard analyses - as a means of applying the NGRIP ice-core chronology to the GRIP and GISP2 cores to synchronize the palaeoclimate profiles derived for the cores, and to help generate the Greenland Ice Core Chronology 2005 (GICC05) (Svensson et al., 2008). These last authors also used ice-core chronologies to help establish the ages for tephra deposits preserved within the cores back to ca. $60 \mathrm{ka}$ cal BP. Traufetter et al. (2004) used high-resolution annual-layer counting and volcanic sulphate deposition values in 13 snow pits and short ice cores at Amundsenisen in Dronning Maud Land, Antarctica, to produce a detailed volcanic chronology covering the period 165 AD to 1997. Several tephra ages used in their model, however, such as those for tephra 28 (Kaharoa tephra: source Mt Tarawera) and tephra 49 (Taupo tephra: source Taupo volcano), differ markedly from those published more recently for these eruptives (Lowe et al., 2008a), and hence their Antarctic occurrence remains unproven.

The Fugloyarbanki tephra, dated at ca. $26.7 \mathrm{ka}$ cal BP in the NGRIP ice core, forms a widespread isochronous marker bed for MOI stage 2 in NGRIP, in marine deposits in the North Atlantic, the Labrador and the Norwegian seas, and around the Faroe Islands near Scotland (Davies et al., 2008). More tephras including the Faroe Marine Ash Zone III (FMAZ III) horizon 
dated at ca. $38 \mathrm{ka}$ cal BP have been identified in NGRIP by Davies et al. (2010b) and used to further help synchronize North Atlantic marine records during the last glacial period. In Europe, Blockley et al. (2007a) showed that there is now potential to independently test climate synchroneity between Greenland, the North Atlantic, and Europe as far south as the Alps via the Icelandic Vedde ash (ca. 12.1 ka cal BP) that marks the middle of biostratigraphic units equivalent to the Younger Dryas stadial. In northern Europe, Icelandic and Jan Mayen-derived tephras have been identified as far as $\sim 2000 \mathrm{~km}$ from source in deposits spanning the last 1000 years, with three layers (Hekla-1, 1104 AD; Öræfajökull, 1362 AD; Askja, 1875 AD) especially providing key tie-points for improving and validating chronological models and for synchronizing palaeoenvironmental records for this period (Wastegård and Davies, 2009).

The SMART project (Synchronising marine and ice-core records using tephrochronology) aims to construct a comprehensive tephrochronological framework for the North Atlantic region for the last interglacial-glacial transition (MOI stages 6-4), focusing on the NEEM ice-core record and existing North Atlantic marine records. This tephra-derived framework helps facilitate the synchronization of paleoclimatic records for this period, underpin chronological models, and test the degree of synchroneity between atmospheric and marine proxies, and thus provide a means of assessing the climatic-forcing mechanisms that operated at the time.

VAST (Volcanism in the Arctic system: geochronology and climate impacts) is another international project in which tephrochronology is playing a key role. The project integrates modelling and paleoenvironmental data to improve understanding of the role of volcanism in climate perturbation in the Arctic system, and uses widespread tephra layers to date and synchronize paleoenvironmental records across the Arctic. In the Southern Ocean near Antarctica, however, Hillenbrand et al. (2008) showed that although sediments dating to MOI stages 6 and 5 were able to be correlated with Antarctic ice core records using tephrochronology, considerable uncertainties were encountered. Problems included a possible failure to recognise all the tephra or cryptotephras present in sedimentary or ice cores, partly because of the 'swamping' 
of records with chemically indistinguishable glass shards (incompleteness of record), and limitations associated with the use of geochemical fingerprinting alone as a correlational tool (Hillenbrand et al., 2008).

In the Japan region, examples of widespread late Quaternary marker beds used for palaeoenvironmental or archaeological correlation include the Aso-4 tephra (erupted from Aso caldera ca. $87 \mathrm{ka}$ and dispersed at least $\sim 3000 \mathrm{~km}$ from source), Aira-Tanzawa tephra (AT) (erupted from Aira caldera ca. $29 \mathrm{ka} \mathrm{cal} \mathrm{BP}$ ), and the Kikai-Akahoya tephra (K-Ah) (erupted from Kikai caldera ca. 7.3 ka cal BP) (Machida, 2002; Aoki, 2008; see Fig. 4B). An INTIMATE project incorporating tephrochronology is now underway in Japan (Moriwaki et al., 2010b).

\subsection{Correcting time-scales}

Tephras as isochrons provide the means to help quantify the marine reservoir effect for correcting the marine-based ${ }^{14} \mathrm{C}$ time-scale, as shown by studies in the Mediterranean Sea, the North Atlantic, and the South Pacific Ocean (Sikes et al., 2000; Ascough et al., 2005; Ohkushi et al., 2007). Further, they enable AMS-based radiocarbon dating of pollen concentrates or biological remains to be evaluated, and for correcting for 'hard water' effects in dating lake sediments (Lowe et al., 1997; Newnham et al., 1998a, 2007b; Lowe, 2008a).

An application where tephrochronology enabled contaminated radiocarbon dates to be identified, thus facilitating a different (correct) palaeoenvironmental interpretation, is that of Newnham et al. (2004) in their analysis of cores from Lake Omapere (Fig. 7). The presence of (compositionally distinctive) glass shards of the ca. 700-yr-old Kaharoa tephra within sediments in the upper part of a core showed that the encapsulating radiocarbon ages of $8.0 \mathrm{ka}{ }^{14} \mathrm{C} \mathrm{BP}$ (below) and $5.4 \mathrm{ka}{ }^{14} \mathrm{C} \mathrm{BP}$ (above) were demonstrably contaminated with reworked 'old' carbon, being about 10 times too old with respect to the Kaharoa tephra isochron. As well as inwashing of old carbon into the lake through likely forest clearance by Polynesian settlers at 
around that time, the considerable potential for reworking of sediments in the shallow lake basin by wind action and other processes, and the continuing discharge of $\mathrm{CO}_{2}$ from near-shore springs, also provided potential for old carbon to be incorporated into the lake system (Newnham et al., 2004).

Another application involved the specific use of LA-ICPMS by Allan et al. (2008) to critically evaluate the stratigraphy of Ocean Drilling Program Site 1123, about $1000 \mathrm{~km}$ east of New Zealand. Using newly-obtained trace element ratios (eg, $\mathrm{Sr} / \mathrm{Y}, \mathrm{Zr} / \mathrm{Th}$ ) and REE analyses on glass, Allan et al. (2008) showed that some tephra layers, which had very similar major element glass-shard compositions, had been included in the composite 1123 record more than once because a repeated $\sim$-m long section in 1123A and $1123 \mathrm{C}$ cores had not initially been recognized. The weak match of part of the oxygen isotope curve (between about 1.2 and 1.4 million years ago) of Site 1123 with other Southern Hemisphere records obtained previously was thus able to be explained by the tephrochronological discovery of this stratigraphic irregularity (Allan et al., 2008).

\subsection{Human evolution and archaeological applications}

Tephrochronology has long been used to help provide ages on early hominins and their activities in eastern Africa and Asia (Hay, 1992; Feibel, 1999; Larick et al., 2001; Tryon and McBrearty, 2002; Woldegabriel et al., 2005; Stollhoffen et al., 2008; Tryon et al., 2008; Deino et al., 2010). Increasingly it is being applied to archaeology and studies of humans in antiquity, including determining the timing and extent of initial human impacts on landscapes (Dugmore et al., 2000, 2004; Lowe et al., 2000; Wastegård et al., 2003; Edwards et al., 2004; Hall and Mauquoy, 2005) or the timing of early human dispersal and associated industries across Europe (e.g., Pyle et al., 2006; Giaccio et al., 2008). 
On the other side of the coin, the palaeoenvironmental response of tephra deposition and associated volcanic impacts (such as toxic aerosol fallout) and their likely impact on hominins and human culture have also been examined (e.g., Drummond, 2004; Grattan, 2006; Dugmore et al., 2007; Neall et al., 2008; Riede, 2008; Riede and Bazely, 2009; Riede and Wheeler, 2009; Williams et al., 2009; Claire Jones, 2010). Grattan et al. (1999) warned of overstating the case, however, invoking the need to examine closely issues of scale and magnitude as well as that of timing. The potential key role of tephrochronology (especially cryptotephrochronology) in underpinning the study of the adaptation of humans to climatic change in Europe since about 40,000 years ago was described by Blockley et al. (2006, 2008a) (see also RESET project).

The timing of the earliest Polynesian settlement of the New Zealand archipelago, the last substantial land mass in the world (outside the polar regions) to be colonized by humans, has been controversial - partly because it has been so recent - and provides an excellent example of how tephrochronology has helped solve a series of geochronological problems. Radiocarbon age data, open to question because of likely contamination of lake sediments by inwashing of old carbon as a result of Polynesian deforestation activities, inbuilt age, or dietary effects, effectively resulted in two contradictory models of settlement: 'early' settlement about 1500-2000 years ago (Sutton, 1987; Sutton et al., 2008) versus 'late' settlement about 700 years ago (Anderson, 1991, 2009; Higham et al., 1999; McGlone and Wilmshurst, 1999). The rhyolitic Kaharoa tephra, erupted from Mt Tarawera in $1314 \pm 12$ AD (Hogg et al., 2003), was distributed widely over much of eastern and northern North Island (Fig. 26). It provides a critical 'settlement datum' to help determine which model was more likely to be correct by linking and dating palynological evidence of initial human impact (derived from analyses of cores from peat bogs and lakes) with archaeological and artefactual evidence (Newnham et al., 1998b; Lowe et al., 1998, 2000). At 19 natural sites where the tephra is found, the start of the sustained decline of tall trees and concomitant rise in bracken fern (Pteridium) spores, together with increases in charcoal, essentially coincided with the deposition of the Kaharoa tephra, or soon after - i.e., deforestation 
by human-fired burning began at ca. $1314 \mathrm{AD}$ or a little later (Fig. 27). But at five sites, the rise in bracken and charcoal and the decline in tall trees began a short while before the fall of the Kaharoa tephra, indicating that deforestation was initiated a few decades before ca. 1314 AD, probably around ca. 1280 AD (Lowe et al., 2002; Lowe and Newnham, 2004).

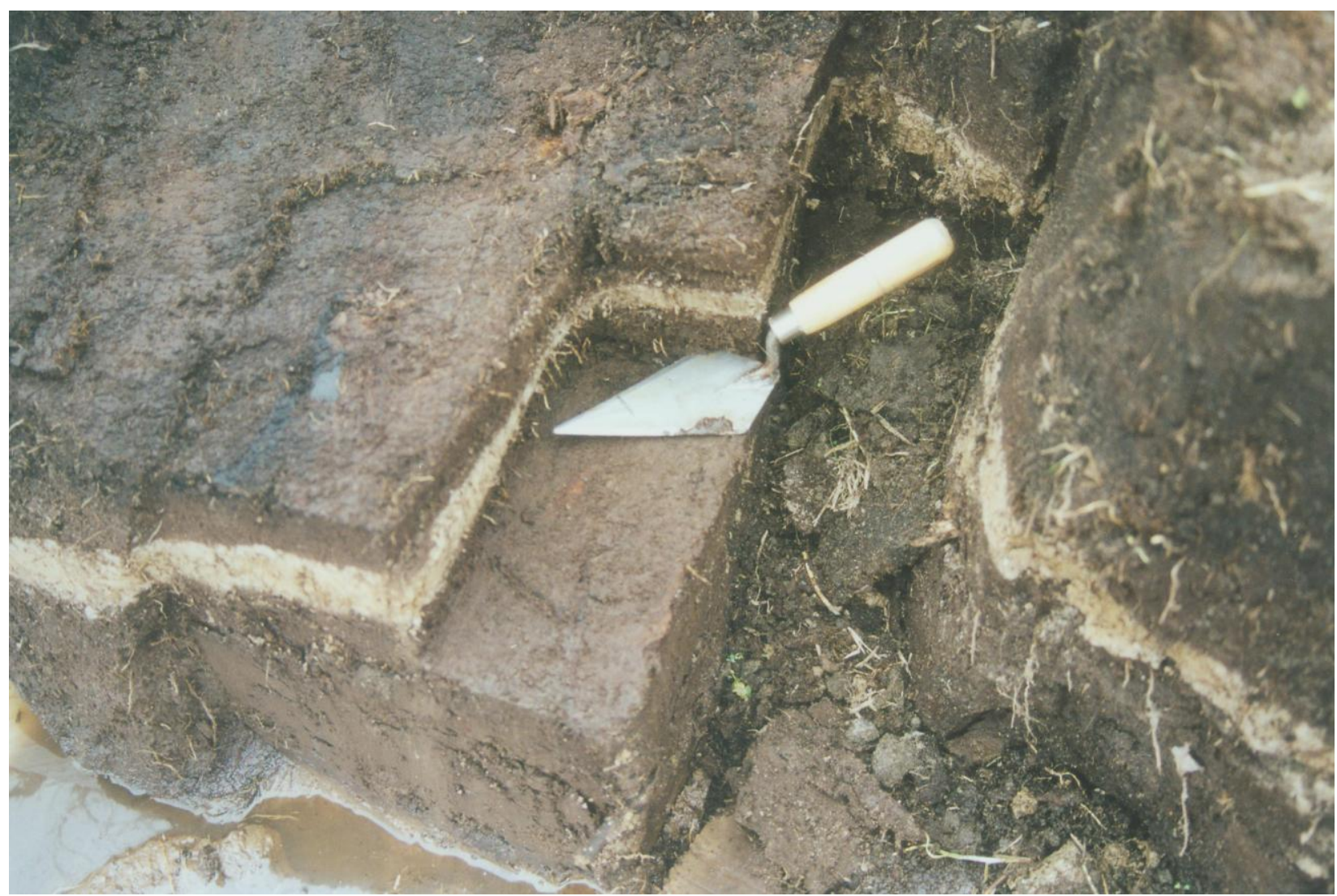

Fig. 26. White Kaharoa tephra layer, approximately 3-5 $\mathrm{cm}$ thick and dated at ca. 1314 AD (Hogg et al., 2003), in peat at Waihi Beach, eastern North Island, New Zealand. Associated pollen analyses for the area were reported by Newnham et al. (1995b). Note blackened charcoalrich upper part (above white Kaharoa tephra layer) probably reflecting pre-historic Polynesian firing. Trowel blade is about $12 \mathrm{~cm}$ long. Photo: D.J Lowe 


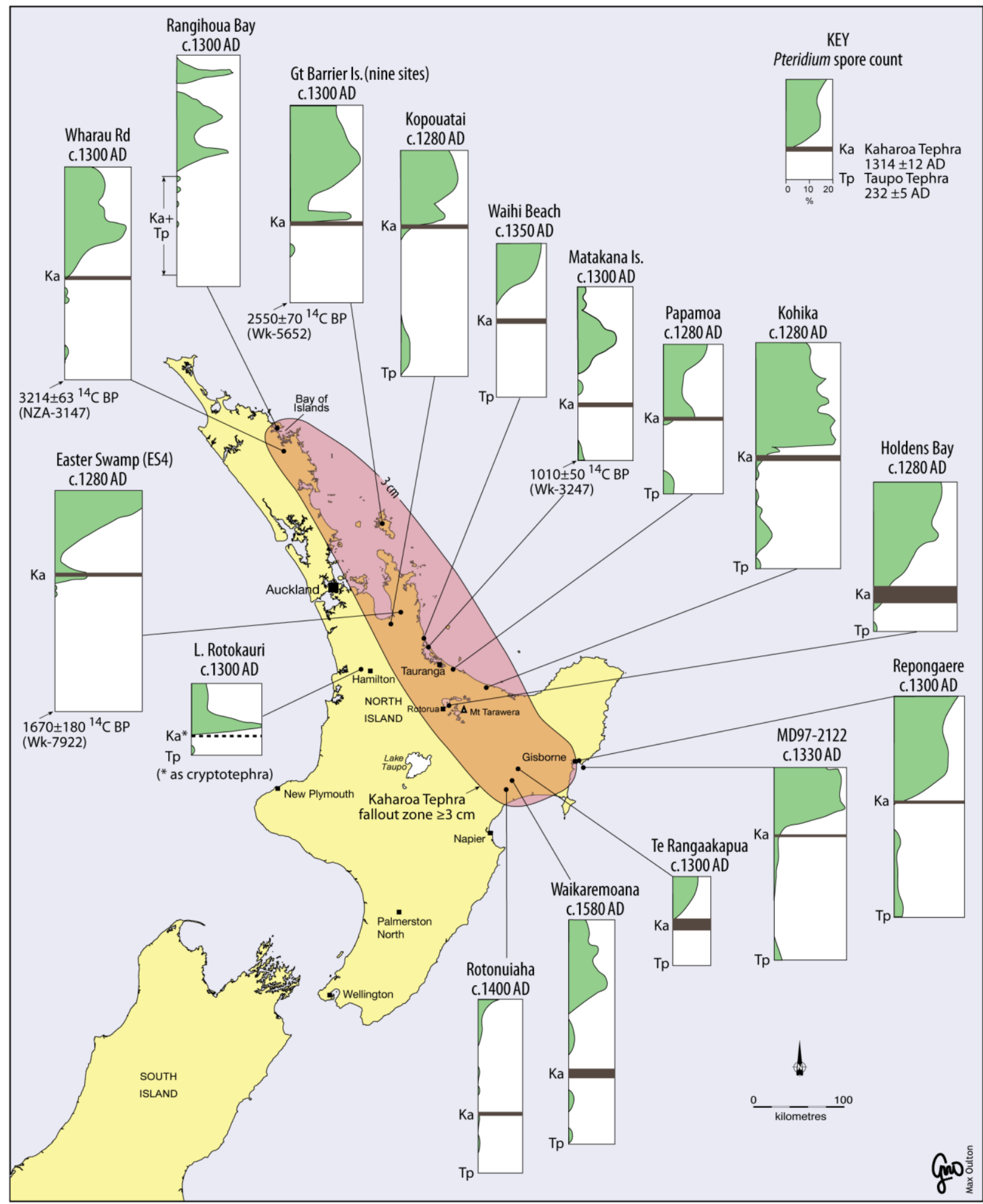

Fig. 27. The Kaharoa tephra provides a chronostratigraphic datum to estimate dates (shown at the top of each Pteridium spore profile, vertical scale in each $\sim 0.5-1 \mathrm{~m}$ ) for initial Polynesianinduced deforestation signals in northern North Island, New Zealand, based on the start of the sustained rise in Pteridium (bracken) spores that matches a concomitant rise in charcoal and decline in tall trees evident in full pollen assemblage diagrams (see references below). The earliest inferred deforestation signal occurs at ca. 1280 AD, just before the Kaharoa tephra was erupted. Taupo tephra and several ${ }^{14} \mathrm{C}$ ages provide earlier (pre-Polynesian) time-planes. After Newnham et al. (1998b) and Lowe et al. (2002) with additional data from Elliot et al. (1997), Horrocks et al. (2001, 2007), Byrami et al. (2002), and D.J. Lowe, R.M. Newnham, and V.A. Hall (unpublished data). Gt, Great; L, Lake. 
At scores of archaeological sites in eastern/northern North Island, no artefacts - with just one exception - have been found beneath the Kaharoa tephra, meaning that (almost) all of these sites date to ca. 1314 AD or later (Higham and Hogg, 1997; Lowe et al., 2000, 2002). The exception comprises a single Pacific rat-nibbled seed case a few centimetres beneath the Kaharoa tephra at an archaeological site on the Coromandel Peninsula (Wilmshurst and Higham, 2004). The exotic Pacific rat (Rattus exulans) arrived in New Zealand as a commensal with the early Polynesians and hence the presence of the distinctive rat incisor marks on the seed case implies that rats (and thus Polynesians) were in New Zealand a short time before the Kaharoa eruption, a conclusion consistent with the palynological evidence in Fig. 27. Although Holdaway (1996) had published 'old' dates up to ca. 2000 years old on Pacific rat bones, and thus suggested that transient contact had been made by Polynesian sailors at that time, more recent ${ }^{14} \mathrm{C}$ dates on ratbone samples from Holdaway's sites, and other sites, have all been ca. 700-750 cal BP, i.e., much younger (Anderson and Higham, 2004; Higham et al., 2004; Wilmshurst et al., 2008). The 'old' dates of Holdaway (1996) were not reproducable and therefore no longer have credibility (see also Anderson, 1996). Moreover, dates on rat-nibbled snail shells in northern North Island (Brook, 2000), and comprehensive suites of rat-nibbled tree seeds in both North and South islands, have all resulted in similar ${ }^{14} \mathrm{C}$ ages of ca. $700-750 \mathrm{cal} \mathrm{BP}$, providing an independent test of the veracity of the young rat-bone ages (Wilmshurst et al., 2008). Consequently, the 'late' settlement model, developed partly using the Kaharoa tephra isochron in northern New Zealand, has been supported. The earliest Polynesian settlement is thus dated at ca. 1280 AD. Early transient contact remains a possibility but currently lacks evidence.

10.4 Distinguishing tephra impact effects from climatic or anthropogenic signals

A problem that may arise in using tephrochronology in palaeoenvironmental reconstruction is that of distinguishing the effects of tephra deposition itself from climatic or anthropogenic 
signals that form the locus of study. Telford et al. (2004), for example, emphasised that it is important to be able to recognise the impact of tephras on lake ecosystems to prevent misinterpretation of palaeolimnological records from volcanic regions. Normally, the impacts from tephra emplacement on the antecedent environment would be most severe at proximal sites, ie., close to volcanic sources, and various studies on such impacts have been undertaken (Clarkson, 1990; Lees et al., 1993; Horrocks and Ogden, 1998; Barker et al., 2000; Eastwood et al., 2002). For example, at the Otamangakau bog, located on the margins of Tongariro volcano in central North Island, tephra fallout probably had significant impacts on the vegetation around the site, promoting grasses and scrub that mimicked or intensified the effects of climate cooling (McGlone and Topping, 1983; Alloway et al., 2007b). The effects of a tephra-fall event may have been prolonged during a cool period because of its impact on soil stability. Alloway et al. (2007b) suggested from high sedimentation rates at Otamangakau that the late-glacial vegetation was constantly disturbed by eruptions that may have facilitated or magnified climate-related changes in vegetation. After ca. $13.0 \mathrm{ka}$ cal BP, fast-growing shrubs became the major successional vegetation after tephra fall events, rather than grasses and cold-tolerant shrubs, suggesting that a cool, frost-basin environment at this site became significantly warmer in winter (Alloway et al., 2007b).

At more distal locations, however, the separation of tephra impacts from other environmental signals may be less clear (Charman et al., 1995; Giles et al., 1999; Edwards et al., 2004; Telford et al., 2004; Payne and Blackford, 2005). Palynological studies in North Island, New Zealand, have shown evidence for the occurrence of forest fires following distal tephra fallout through increases in charcoal fragments and bracken spores immediately above tephra layers preserved in peat bogs or lake deposits (e.g., Newnham et al., 1995a; Wilmshurst and McGlone, 1996; Newnham and Alloway, 2004). In such cases, high-resolution sampling to undertake pollen analysis, for example, is essential, as demonstrated by Newnham and Lowe (2000) in separating the impact of the deposition of the ca. $13.7 \mathrm{ka}$ cal BP Waiohau tephra from a 
subsequent decline in temperature (reflecting in part the Antarctic Cold Reversal) a century or two later at ca. 13.6 ka cal BP (Hadjas et al., 2006; Lowe et al., 2008a). Similarly, Telford et al. (2004) undertook high-resolution sampling of diatoms immediately above and below tephra layers in lakes in Mexico to establish their impact relative to that of concomitant climatic change. Detectable responses to the deposition of thin tephras were common in over half of the tephra layers investigated, and the diatom responses lasted for at least several decades, a duration that may have been undetected in low resolution palaeoenvironmental studies. Nevertheless, the impact of these tephra layers was insufficient to perturb the underlying long-term climate forcing of the lake systems (Telford et al., 2004). In northeast Germany, limnic diatom populations increased markedly from the input of silica by the Laacher See tephra, which provided a nutrient source for the building of frustules and simultaneously prevented dissolution of dead diatoms. As in Mexico, the effect was short-lived and terminated when the tephra was covered by new lake sediments (de Klerk et al., 2008).

In contrast, Kilian et al. (2006) suggested that the deposition of a thin tephra layer in the superhumid, pristine environment of the southernmost Andes resulted in a prolonged impact lasting several thousand years, thus causing a perturbation in the palaeoclimatic proxy record. The release of $\mathrm{CO}_{2}$ from pumice grains within the tephra had caused acidification in soils and lakes (Kilian et al., 2006).

In the Klondike region of the central Yukon Territory, deposition of the Dawson tephra in late winter may have, in part, minimized the terrestrial ecological impacts of its fallout on zonal steppe-tundra vegetation through the re-transportation of tephra from hillslopes to the riparian areas in spring, where the tephra became incorporated into local fluvial systems (Froese et al., 2006).

Separating the impacts of distal tephra fall from possible human effects also requires highresolution studies and results may be equivocal, as shown by Giles et al. (1999) in northern New Zealand where deposition of the Kaharoa tephra coincided approximately with the arrival of the 
first Polynesians (noted above). As illustrated in Fig. 27, however, palynostratigraphic evidence of the rise in bracken and charcoal and the decline in tall trees began a few decades before the fall of the Kaharoa tephra at five sites, indicating that this deforestation signal thus cannot represent an eruption-induced signal (Newnham et al., 1998b). Giles et al. (1999) inferred that the fallout of distal Kaharoa tephra had caused some environmental disturbance, however, such as the decline of certain taxa.

\subsection{Spatial analysis}

Dugmore et al. (2004, p. 181) commented that "at its best tephrochronology should add insight at many different levels, and be greater than the sum of its constituent parts", and went on to emphasise the largely untapped potential the discipline has for 3-D reconstructions and for the spatial analysis of pattens of change through time. The ways in which environmental records vary spatially through time are essential data in many Quaternary studies, and provide constraints for effective modelling of environmental change (Dugmore et al., 2004). Therefore the development of 3-D reconstructions based on multiple, tephra-containing profiles (i.e., isochronous time-lines) provide unique detailed data on changing spatial patterns, and help enable the physical changes that have taken place in a landscape to be understood (Dugmore et al., 2004; Newton et al., 2007). For example, changing landscape patterns before and after human colonization and within periods of contrasting climates and cultures have been studied using this approach (Dugmore et al., 2000, 2004). In attempting to explain specifically why accelerated soil erosion has occurred in Iceland, Dugmore et al. (2004) emphasised that a 3-D spatial approach using tephrochronology (providing both spatial and temporal resolution across entire landscapes) together with geomorphological data, cultural records, and biomass modelling had been critical in developing answers, as documented by Simpson et al. (2001). This approach was described as one of 'historical ecology' where spatially referenced environmental data are divided into human time- 
scales so that environmental and cultural records are able to be compared and connected using tephrochronolgy (Dugmore et al., 2004). The application of geographic information systems (GIS) and the use of geostatistics (e.g., kriging) are likely to underpin many future applications of this sort of multidisciplinary approach to spatial analysis involving tephrochronology, as well as traditional applications such as isopach or isomass mapping where point data are converted to areal data, as reported in Japan by Suzuki et al. (2010).

Very-high resolution topographic data generated by emerging technologies such as Lidar, an airborne swath-mapping laser impulse technique, also have great potential in spatial tephrochronological applications including remote sensing (e.g., Spinetti et al., 2009; Begg and Mousloupolou, 2010).

\section{Summary and conclusions}

Tephrochronology, the characterization and use of volcanic-ash layers as a unique stratigraphic linking, synchronizing, and age-equivalent dating tool has become a globallypractised discipline of immense practical value in a wide range of subjects including Quaternary stratigraphy and geochronology, palaeoenvironmental reconstruction, volcanology, geomorphology, archaeology, human evolution, and palaeoanthropology. Developments in dating and analytical methods, and concepts, in the past two decades have led to a number of important advances in the practise and application of tephrochronology, as follows.

(1) The advent of systematic studies of cryptotephras - the identification, correlation, and dating of sparse, fine-grained glass-shard and/or crystal concentrations 'hidden' within sediments has been revolutionary. Not without difficulties, such as explaining distributional variability and reworking and taphonomic considerations, the upshot nevertheless has been the extension of tephra isochrons hundreds to several thousands of kilometres from source volcanoes (in 
some cases $3000 \mathrm{~km}$ or further). Ice-core evidence shows that transport of glass shards globally is possible.

(2) A better understanding of the need for high-quality and comprehensive analytical data and high-resolution chronologies, and for care in erecting tephrostratigraphic nomenclature to avoid or reduce ambiguity that may arise from future research, is now more evident in recent tephra studies.

(3) Tephra and cryptotephra deposits provide records of volcano eruption histories, and their study thus aids volcanic hazard analysis and mitigation. For example, Newnham et al. (2010) identified an increase in respiratory-related mortality in Auckland and Hamilton in New Zealand as a possible consequence of the effects of diffuse, fine-grained ash fallout (as cryptotephra) from the 1996 Mt Ruapheu eruption. As well, it is evident that tephra sequences may be more comprehensive at medial to distal locations in sediments, including ice, than at proximal locations, and that the interbedding of the layers from multiple sources at such locations uniquely reveals their complex stratigraphic interrelationships.

(4) The long-standing EPMA technique for glass analysis is being used with increasing precision, thus enabling subtle distinctions in major element populations to be identified as data quality improve. The rigorous use of standards (both primary and secondary) during microprobe-based analysis of new glass shards, and the concominant analysis of glass from relevant reference tephras, are enhancing correlation probabilities. Most recently, the ability to reliably analyse glass using narrower beam diameters $(\sim 5 \mu \mathrm{m})$ than previously possible is another extremely important development (Hayward, submitted for publication).

Analyses by EPMA of crystals of Fe-Ti oxides and ferromagnesian minerals, and geothermometry, are also proving useful to affect correlations where previously data were ambiguous. The analysis of titanomagnetite or other resistant minerals, or of melt inclusions (glass) preserved within quartz grains, has enabled strongly-weathered tephra beds to be correlated, and their sources identified, in several pathfinding studies. 
(5) The LA-ICPMS and ion probe methods for trace-element and REE analysis of individual, fine-grained glass shards ( $20 \mu \mathrm{m}$ resolution or smaller) represent another landmark advance in tephrochronology. Such methods, more difficult for very fine shards, are generating more detailed and robust fingerprints for enhancing tephra-correlation efficacy for deposits previously of equivocal identification or very far from source, greatly extending the potential range over which geochemical correlation of tephras can be undertaken and hence applied as a dating tool.

(6) Detailed analysis of tephra composition has provided insight into volcanic petrogenesis and revealed magmatic heterogeneity at some volcanoes. Consequently it has become evident that multiple fingerprints may arise according to tephra-dispersal direction during a 'single' eruption episode, adding complexity and the need for a comprehensive sampling approach in making long-range correlations. A method has been developed to correct for heterogeneity in andesitic and basaltic glass that may arise through unwitting analysis of micro-inclusions.

(7) The glass-based isothermal-plateau fission-track (ITPFT) method is another exceptionally important development because it has enabled landscapes and sequences to be dated accurately where previously no dates were obtainable or where dating was problematic.

(8) Developments in other radiometric methods, such as U-Th and (U-Th)/He on single zircon crystals and ${ }^{40} \mathrm{Ar} /{ }^{39} \mathrm{Ar}$ methods on sanidines and biotite especially, are also helping improve the dating of tephras containing these minerals, and to help reconcile chronostratigraphic discrepancies and ambiguities.

(9) The continuing rise of Bayesian-based age modelling (including flexible-depositional modelling and wiggle-match dating) is helping to improve age tephrochronometric frameworks for the late-glacial to Holocene period especially, highlighting the need both to improve precision and accuracy and to report errors realistically for tephra ages using calendrical probability ranges. 
(10) Statistical tools such as cluster analysis, discriminant function analysis, and MANOVA to facilitate objective correlation of tephras via geochemical data are being used more widely and need further development and application.

(11) Tephrochronology has continued to be used as a Quaternary stratigraphic and geochronological tool in increasingly diverse disciplines. In particular, it is proving useful in testing and correcting age models developed by radiometric or other dating methods.

(12) Tephrochronology is now seen as a key correlation or 'synchronization' tool - provided risks of miscorrelation or misassociation are evaluated and minimized - in high-resolution palaeoenvironmental projects and in dating, integrating, and interpreting humanenvironmental interactions in antiquity.

Future studies in tephrochronology (sensu lato) are partly encapsulated in the INTREPID project (Enhancing tephrochronology as a global research tool). The central goals of this overarching project are to advance understanding and efficacy in fingerprinting, correlating, and dating techniques and to evaluate and quantify uncertainty in tephrochronology, and thus enhance research capability for a wide range of Quaternary research projects around the world. As well as continuing to refine and develop geo-analytical methods, and to improve precision and accuracy in age modelling using a range of methods, an area of considerable potential in future research involving tephrochronology is the integration of spatially referenced palaeoenvironmental and archaeometric data into 3-D reconstructions of landscapes through time, and the development of spatial representations of data such as tephra thicknesses or mass or glass-shard concentrations using geostatistical techniques to interpolate between measured points. Tephra taphonomy requires further examination, especially in high-resolution studies involving cryptotephras. The development of databases and the ongoing scrutiny of tephrochronology as a discipline of science are also worthy subjects, amongst others, for continuing research (Newton et al., 2007). 


\section{Acknowledgements}

I am very grateful indeed to Dr Simon Blockley (Royal Holloway, University of London), Dr Siwan Davies (Swansea University), and Associate Prof Roger Briggs (University of Waikato) for reviewing the paper and for valuable comments. Additional information, advice, comments, and support were provided by Dr Chris Hayward (University of Edinburgh), Dr Stephen Kuehn (Concord University), Dr Nick Pearce (Aberystwyth University), Prof Hiroshi Moriwaki (Kagoshima University), Dr Malcolm Sheard (Geological Survey, Minerals and Energy Resources, South Australia), Dr Richard Smith (New Zealand Ministry of Civil Defence and Emergency Management), Prof Alan Robock (Rutgers University), Prof Lionel Carter (Victoria University of Wellington), Prof Caitlin Buck (University of Sheffield), Prof John Westgate (University of Toronto), Prof Christian Tryon ((New York University), Assoc Prof Brent Alloway (Victoria University of Wellington), and Profs Ray Harlow and Cam Nelson and Drs Adrian Pittari, Alan Hogg, and Brendan Roddy (all University of Waikato). I especially thank Dr Maria Gehrels (University of Plymouth) for providing electron micrographs (Figs. 8 and 12), Dr Nick Pearce for providing Figs. 19 and 20, and Max Oulton (University of Waikato) for preparing many of the figures. Dr Phil Shane (University of Auckland) provided a framework for constructing Fig. 10, Prof Rewi Newnham (Victoria University of Wellington) and Prof Valerie Hall (Queen's University Belfast) contributed data towards Fig. 27, and Dr Maarten Blaauw (Queen's University Belfast) provided a preprint of Blaauw (submitted) and helped greatly with Bayesian age modelling in earlier projects. Dr Tobita Matsu'ura (formerly Geological Survey of Japan, AIST), Anna Bourne and Prof John Lowe (Royal Holloway, University of London), Prof Christian Tryon, and Dr Chris Hayward provided me with recently submitted papers. I am grateful to the editor Dr Rainer Grün for his encouragement and patience. The paper is an output of the INTREPID project "Enhancing tephrochronology as a global research tool through improved fingerprinting and correlation techniques and uncertainty modelling" (INQUA project 
0907), an initiative of the International Focus Group on Tephrochronology and Volcanism,

INTAV. Support from the Stratigraphy and Chronology Commission of INQUA and its president Prof Brad Pillans (ANU) is also gratefully acknowledged. Finally, I thank Prof Caitlin Buck for supporting my visit to the UK in June, 2008, to participate in the SUPRAnet workshop, and the Japan Society for the Promotion of Science for supporting my visit to Japan in May, 2010, in part to attend the "Active Tephra" conference in Kirishima.

\section{References}

Adams, N.K., de Silva, S. L., Self, S., Salas, G., Schubring, S., Permenter, J.L., Arbesman, K., 2001. The physical volcanology of the 1600 eruption of Huaynaputina, southern Peru. Bulletin of Volcanology 62, 493-518.

Allan, A.S.R., Baker, J.A., Carter, L., Wysoczanksi, R.J., 2008. Reconstructing the Quaternary evolution of the world's most active silicic volcanic system: insights from a $\sim 1.65$ Ma deep ocean tephra record sourced from the Taupo Volcanc Zone, New Zealand. Quaternary Science Reviews 27, 2341-2360.

Alloway, B.V., Stewart, R.B., Neall, V.E., Vucetich, C.G., 1992. Climate of the Last Glaciation in New Zealand, based on aerosolic quartz influx in an andesitic terrain. Quaternary Research $38,170-179$.

Alloway, B.V., Pillans, B.J., Sandhu, A.S., Westgate, J.A., 1993. Revision of the marine chronology in the Wanganui Basin, New Zealand, based on the isothermal plateau fission track dating of tephra horizons. Sedimentary Geology 82, 299-310.

Alloway, B.V., Lowe, D.J., Chan, R.P.K., Eden, D.N., Froggatt, P.C., 1994. Stratigraphy and chronology of the Stent tephra, a c. 4000 year old distal silicic tephra from Taupo Volcanic Centre, New Zealand. New Zealand Journal of Geology and Geophysics 37, 37-47.

Alloway, B.V., Westgate, J., Pillans, B., Pearce, N., Newnham, R.M., Bryami, M., Aarburg, S., 2004a. Stratigraphy, age and correlation of middle Pleistocene silicic tephras in the Auckland 
region, New Zealand: a prolific distal record of Taupo Volcanic Zone volcanism. New Zealand Journal of Geology and Geophysics 47, 447-479.

Alloway, B.V., Pribadi, A., Westgate, J.A., Bird, M., Fifield, L.K., Hogg, A.G., Smith, I., 2004 b. Correspondence between glass-FT and ${ }^{14} \mathrm{C}$ ages of silicic pyroclastic flow deposits sourced from Maninjau caldera, west-central Sumatra. Earth and Planetary Science Letters 227, 121133.

Alloway, B.V., Pillans, B.J., Carter, L., Naish, T.R., Westgate, J.A., 2005. Onshore-offshore correlation of Pleistocene rhyolitic eruptions from New Zealand: implications for TVZ eruptive history and paleoenvironmental construction. Quaternary Science Reviews 24, 16011622.

Alloway, B.V., Larsen, G., Lowe, D.J., Shane, P.A.R., Westgate, J.A., 2007a. Tephrochronology. In: Elias, S.A. (Ed.), Encyclopaedia of Quaternary Science. Elsevier, London, pp. 2869-2898. Alloway, B.V., Lowe, D.J., Barrell, D.J.A., Newnham, R.M.., Almond, P.C., Augustinus, P.C., Bertler, N.A., Carter, L., Litchfield, N.J., McGlone, M.S., Shulmeister, J., Vandergoes, M.J., Williams, P.W., NZ-INTIMATE members, 2007b. Towards a climate event stratigraphy for New Zealand over the past 30,000 years (NZ-INTIMATE project). Journal of Quaternary Science 22, 9-35.

Anderson, A.J., 1991. The chronology of colonization in New Zealand. Antiquity 65, 767-795.

Anderson, A.J., 1996. Was Rattus exulans in New Zealand 2000 years ago? AMS radiocarbon ages from Shag River Mouth. Archaeology in Oceania 31, 178-184.

Anderson, A.J., 2009. Origins, settlement and society of pre-European South Polynesia. In: Byrnes, G. (Ed.), The New Oxford History of New Zealand. Oxford University Press, Melbourne, pp. 23-46.

Anderson, A.J., Higham, T.F.G., 2004. The age of rat introduction in New Zealand: further evidence from Earthquakes \#1, North Otago. New Zealand Journal of Archaeology 24, 135147. 
Anderson, R.Y., Nuhfer, E.B., Dean, W.E., 1984. Sinking of volcanic ash in uncompacted sediment in Williams Lake, Washington. Science 225, 505-508.

Andrews, J.T., Eberl, D.D., Kristjánsdóttir, G.B., 2006. An exploratory method to detect tephras from quantitative XRD scans: examples from Iceland and east Greenland marine sediments. The Holocene 16, 1035-1042.

Aoki, K., 2008. Revised age and distribution of ca. 87 ka Aso-4 tephra based on new evidence from the northwest Pacific Ocean. Quaternary International 178, 100-118.

Arakawa, Y., Kurosawa, M., Takahashi, K., Kobayashi, Y., Tsukui, M., Amakawa, H., 1998. Sr$\mathrm{Nd}$ isotopic and chemical characteristics of the silicic magma reservoir of the Aira pyroclastic eruption, southern Kyushu, Japan. Journal of Volcanology and Geothermal Research 80, 179194.

Ascough, P., Cook, G., Dugmore, A., 2005. Methodological approaches to determining the marine radiocarbon reservoir effect. Progress in Physical Geography 29, 532-547.

Austin, W.E.N., Abbott, P.M., 2010. Comment: Were last glacial climate events simultaneous between Greenland and France? A quantitative comparison using non-tuned chronologies. M. Blaauw, B. Wohlfarth, J. A. Christen, L. Ampel, D. Veres, K. Hughen, F. Preusser and A. Svensson (2010). Journal of Quaternary Science 25, 1045-1046

Austin, W.E.N., Wilson, L.J., Hunt, J.B., 2004. The age and chronostratigraphical significance of North Atlantic Ash Zone II. Journal of Quaternary Science 19, 137-146.

Barbetti, M., Sheard, M.J., 1981. Paleomagnetic results from Mounts Gambier and Schank, South Australia. Journal of the Geological Society of Auustralia 28, 385-394.

Barker, P., Telford, R., Merdaci, O., Williamson, D., Taieb, M., Vincens, A., Gibert, E., 2000. The sensitivity of a Tanzanian crater lake to catastrophic tephra input and four millennia of climate change. The Holocene 10, 303-310.

Baron, D., Negrini, R.M., Golob, E.M., Miller, D., Sarna-Wojcicki, A., Fleck, R.J., Hacker, B., Erendi, A., 2008. Geochemical correlation and ${ }^{40} \mathrm{Ar} /{ }^{39} \mathrm{Ar}$ dating of the Kern River ash bed and 
related tephra layers: implications for the stratigraphy of petroleum-bearing formations in the San Joaquin Valley, California. Quaternary International 178, 246-260.

Basile, I., Petit, J., Touron, S., Grousset, F., Barkov, N., 2001. Volcanic layers in Antarctic (Vostok) ice cores: source identification and atmospheric implications. Journal of Geophysical Research 106 (D23), 31915-31931.

Bayliss, A., 2007. Bayesian buildings: an introduction for the numerically challenged. Vernacular Architecture 38, 75-86.

Beaudoin, A.B., King, R.H., 1986. Using discriminant function analysis to identify Holocene tephras based on magnetite composition: a case study from the Sunwapta Pass area, Jasper National Park. Canadian Journal of Earth Sciences 2, 804-812.

Begét, J.E., Keskinen, M.J., 2003. Trace-element geochemistry of individual glass shards of the Old Crow tephra and the age of the Delta glaciation, central Alaska. Quaternary Research 60, 63-69.

Begg, J.G., Mouslopoulou, V., 2010. Analysis of late Holocene faulting within an active rift using Lidar, Taupo Rift, New Zealand. Journal of Volcanology and Geothermal Research 190, 152167.

Beierle, B., Bond, J., 2002. Density-induced settling of tephra through organic lake sediments. Journal of Paleolimnology 28, 433-440.

Beck, J.W., Richards, D.A., Edwards, R.L., Silverman, B.W., Smart, P.L., Donahue, D.J., HererraOsterheld, S., Burr, G.S., Calsoyas, L., Jull A.J.T., Biddulph, D., 2001. Extremely large variations of atmospheric C-14 concentration during the Last Glacial period. Science 292, 2453-2458.

Benny, L.A., Kennedy, N.M., Kirkman, J.H., Stewart, R.B., 1988. Mineralogical and textural discrimination of loess derived from a tephra near Rotorua, New Zealand. Australian Journal of Soil Research 26, 301-312. 
Bergman, J., Wastegård, S., Hammarlund, D., Wohlfarth, B., Riberts, S.J., 2004. Holocene tephra horizons at Klocka Bog, west-central Sweden: aspects of reproducibility in subarctic peat deposits. Journal of Quaternary Science 19, 241-249.

Berryman, K., Marden, M., Eden, D.N., Mazengarb, C., Ota, Y., Moriya, I., 2000. Quaternary river terraces of the Waipaoa River, East Coast, New Zealand, and their tectonic and paleoclimatic significance. New Zealand Journal of Geology and Geophysics 43, 229-245.

Berryman, K., Villamor, P., Nairn, I.A.m, van Dissen, R., Begg, J., lee, J., 2008. Late Pleistocene surface rupture history of the Paeroa Fault, Taupo Rift, New Zealand. New Zealand Journal of Geology and Geophysics 51, 135-158

Blaauw, M., submitted for publication. Out of tune: the dangers of aligning proxy archives. Quaternary Science Reviews.

Blaauw, M., 2010. Methods and code for 'classical' age-modelling of radiocarbon sequences. Quaternary Geochronology 5, 512-518.

Blaauw, M., Christen, J.A., submitted for publication. Flexible paleoclimate age-depth models using an autoregressive gamma process. Bayesian Analysis.

Blaauw, M., Wohlfarth, B., 2010. Reply: Were last glacial climate events simultaneous between Greenland and France? A quantitative comparison using non-tuned chronologies. Journal of Quaternary Science 25, 1047.

Blaauw, M., Bakker, R., Christen, J.A., Hall, V.A., van der Plicht, J., 2007. Bayesian framework for age-modelling of radiocarbon dated peat deposits: case studies from The Netherlands. Radiocarbon 49, 357-367.

Blaauw, M., Wohlfarth, B., Christen, J.A., Ampel, L., Veres, D., Hughes, K., Preusser, F., Svensson, A., 2010. Were last glacial climate events simultaneous between Greenland and France? A quantitative comparison using non-tuned chronologies. Journal of Quaternary Science 25, 387-394. 
Black, K.P., Nelson, C.S., Hendy, C.H., 1988. A spectral analysis procedure for dating Quaternary deep-sea cores and its application to a high-resolution Brunhes record from the Southwest Pacific. Marine Geology 83, 21-30.

Black, T.M., Shane, P.A.R., Westgate, J.A., Froggatt, P.C., 1996. Chronological and palaeomagnetic constraints on widespread welded ignimbrites of the Taupo volcanic zone, New Zealand. Bulletin of Volcanology 58, 226-238.

Blockley, S.P.E., Pyne-O’Donnell, S.D.F., Lowe, J.J., Mathews, I.P., Stone, A., Pollard, A.M., Turney, C. S. M., Molyneux, E. G., 2005. A new and less destructive laboratory procedure for the physical separation of distal tephra glass shards from sediments. Quaternary Science Reviews 24, 1952-1960.

Blockley, S.P.E., Blockley, S.M., Donahue, R.E., Lane, C.S., Lowe, J.J., Pollard, A.M., 2006. The chronology of abrupt climate change and Late Upper Palaeolithic human adaptation in Europe. Journal of Quaternary Science 21, 575-584.

Blockley, S.P.E., Lane, C.S., Lotter, A.F., Pollard, A.M., 2007a. Evidence for the presence of the Vedde Ash in central Europe. Quaternary Science Reviews 26, 3030-3036.

Blockley, S.P.E., Blaauw, M., Bronk Ramsey, C., van der Plicht, J., 2007b. Building and testing age models for radiocarbon dates in lateglacial and early Holocene sediments. Quaternary Science Reviews 26, 1915-1926.

Blockley, S.P.E., Bronk Ramsey, C., Higham, T.F.G., 2008a. The Middle to Upper Paleolithic transition: dating, stratigraphy, and isochronous markers. Journal of Human Evolution 55, 764-771.

Blockley, S.P.E., Bronk Ramsey, C., Lane, C.S., Lotter, A.F., 2008b. Improved age modelling approaches as exemplified by the revised chronology for the central European varved lake Soppensee. Quaternary Science Reviews 27, 61-71.

Blockley, S.P.E., Bronk Ramsey, C., Lane, C.S., Lotter, A.F., 2010. Age modelling in tephrochronology: the application of Bayesian approaches ro integrating tephra with other 
chronological information. Abstracts, International Field Conference on Tephrochronology, Volcanism and Human Activity, Kirishima, Japan (9-17 May). INQUA International Focus Group on Tephrochronology and Volcanism, pp.13-14.

Boer, W., van den Bergh, G.D., de Haas, H., de Stigter, H.C., Gleles, R., van Weering, T.C.E., 2006. Validation of accumulation rates in Teluk Banten (Indonesia) from commonly applied $\mathrm{Pb}-210$ models, using the 1883 Krakatau tephra as time marker. Marine Geology 227, 263 277.

Bonadona, C., 2006. Probabilistic modelling of tephra dispersion. In: Mader, H.M., Coles, S.G., Connor, C.B., Connor, L.J. (Eds), Statistics in Volcanology. Special Publications of IAVCEI (Geological Society, London) 1, pp. 243-259.

Borchardt, G.A., Harward, M.E., Schmitt, R.A., 1971. Correlation of volcanic ash deposits by activation analysis of glass separates. Quaternary Research 1, 247-260.

Borchardt, G.A., Norgren, J.A., Harward, M.E., 1973. Correlation of ash layers in peat bogs of eastern Oregon. Geological Society of America Bulletin 84, 3101-3108.

Borisova, A.Y., Freydier, R., Polvé, M., Salvi, S., Candaudap, F., Aigouy, T., 2008. In situ multielement analysis of the Mount Pinatubo quartz-hosted melt inclusions by NIR Femtosecond laser ablation-inductively coupled plasma-mass spectrometry. Geostandards and Geoanalytical Research 32, 209-229.

Bourne, A.J., Lowe, J.J., Trincardi, F., Asioli, A., Blockley, S.P.E., Bowen, S.W., Matthews, I.P., Piva, A., Vigliotti, L., in press. Distal tephra record of the last c. 105,000 years from core PRAD 1-2 in the central Adriatic Sea: implications for marine tephrostratigraphy. Quaternary Science Reviews.

Boygle, J., 1999. Variability of tephra in lake and catchment sediments, Svínavatn, Iceland. Global and Planetary Change 21, 129-149. 
Brauer, A., Wulf, S., Mangil, C., Moscariello, A., 2006. Tephrochronological dating of varved interglacial lake deposits from Piànico-Sèllere (Southern Alps, Italy) to around 400 ka. Journal of Quaternary Science 22, 85-96.

Brendryen, J., Haflidason, H., Sejrup, H.P., 2010. Norwegian Sea tephrostratigraphy of marine isotope stages 4 and 5: prospects and problems for tephrochronology in the North Atlantic region. Quaternary Science Reviews 29, 847-864.

Briggs, R.M., Itaya, T., Lowe, D.J., Keane, A.J., 1989. Ages of the Pliocene-Pleistocene Alexandra and Ngatutura Volcanics, western North Island, New Zealand, and some geological implications. New Zealand Journal of Geology and Geophysics 32, 417-427.

Bronk Ramsey, C., 2008. Depositional models for chronological research. Quaternary Science Reviews 27, 42-60.

Brook, F.J., 2000. Prehistoric predation of the landsnail Placostylus ambagiosus Suter (Stylommatophra: Bulimulidae), and evidence for the timing of establishment of rats in northernmost New Zealand. Journal of the Royal Society of New Zealand 30, 227-241.

Byrami, M., Ogden, J., Deng, Y., Horrocks, M., Shane, P., Palmer, J., 2002. A palynological study of Polynesian and European effects on vegetation in Coromandel, New Zealand, showing the variability between four records from a single swamp. Journal of the Royal Society of New Zealand 32, 507-531.

Bryant, C.J., Arculus, R.J., Eggins, S.M., 1999. Laser ablation-inductively coupled plasma-mass spectrometry and tephras: a new approach to understanding arc-magma genesis. Geology 27, 1119-1122.

Buck, C.E., Millard, A.R. (Eds) 2004. Tools for Constructing Chronologies: Crossing Disciplinary Boundaries. Lecture Notes in Statistics 177, pp. 1-256 (Springer, London).

Buck, C.E., Higham, T.F.G., Lowe, D.J., 2003. Bayesian tools for tephrochronology. The Holocene 13, 639-647. 
Carey, S., 1997. Influence of convective sedimentation on the formation of widespread tephra fall layers in the deep sea. Geology 25, 839-842.

Carey, S., Maria, A., Sigurdsson, H., 2000. Use of fractal analysis for discrimination of particles from primary and reworked jökulhlaup deposits in SE Iceland. Journal of Volcanology and Geothermal Research 104, 65-80.

Carr, M.J., 2010. Igpet for Windows. Terra Softa Inc. Version: Jan. 2, 2010. http://home.comcast.net/ carrvolcano/site/?/page/Igpet_for_Windows_and_Mac/

Carter, L., Nelson, C.., Neil, H.L., Froggatt, P.C., 1995. Correlation, dispersal, and preservation of the Kawakawa Tephra and other late Quaternary tephra layers in the southwest Pacific Ocean. New Zealand Journal of Geology and Geophysics 38, 29-46.

Carter, L., Manighetti, B., Elliot, M., Trustrum, N., Gomez, B., 2002. Source, sea level and circulation effects on the sediment flux to the deep ocean over the past $15 \mathrm{ka}$ off eastern New Zealand. Global and Planetary Change 33, 339-355.

Carter, L., Shane, P.A.R., Alloway, B.V., Hall, I.R., Harris, S.E., Westgate, J.A., 2003. Demise of one volcanic zone and birth of another - a 12 m.y. marine record of major rhyolitic eruptions from New Zealand. Geology 31, 493-496.

Caseldine, C., Baker, A., Barnes, W.L., 1999. A rapid, non-destructive scanning method for detecting distal tephra layers in peats. The Holocene 9, 635-638.

Cassata, W.S., Singer, B.S., Liddicoat, J.C., Coe, R.S., 2010. Reconciling discrepant chronologies for the geomagnetic excursion in the Mono Basin, California: insights from new ${ }^{40} \mathrm{Ar} /{ }^{39} \mathrm{Ar}$ dating experiments and a revised relative paleointensity correlation. Quaternary Geochronology 5, 533-543.

Charlier, B.L.A., Wilson, C.J.N., 2010. Chronology and evolution of caldera-forming and postcaldera magma systems at Okataina volcano, New Zealand, from zircon U-Th model-age spectra. Journal of Petrology 5, 1121-1141. 
Charman, D.J., Grattan, J., 1999. An assessment of discriminant function analysis in the identification and correlation of distal Icelandic tephras in the British Isles. Geological Society (London) Special Publications 161, 147-160.

Charman, D.J., West, S., Kelly, A., Grattan, J.P., 1995. Environmental response to tephra deposition in the Strath of Kildonan, northern Scotland. Journal of Archaeological Science 22, 799-809.

Christiansen, R.L., Peterson, D.W., 1981. Chronology of the 1980 eruptive activity. In: Lipman, P.W., Mullineaux, D.R. (Ed.), The 1980 Eruptions of Mount St. Helens, Washington. Geological Survey Professional Paper 1250, 17-30.

Chun, J.-H., Cheong, D., Ikehara, K., Han, S.-J., 2007. Age of the SKP-I and SKP-II tephras from the southern East Sea/Japan Sea: implications for interstadial events recorded in sediment from marine isotope stages 3 and 4. Palaeogeography, Palaeoclimatology, Palaeoecology 247, 100-114.

Churchman, G.J., Lowe, D.J., in press. Alteration, formation, and occurrence of minerals in soils. In: Li, Y., Sumner, M.E. (Ed.), Handbook of Soil Science, $2^{\text {nd }}$ ed. Taylor and Francis, London. Cioni, R., D’Oriano, C., Bertagnini, A., 2008. Fingerprinting ash deposits of small scale eruptions by their physical and textural features. Journal of Volcanology and Geothermal Research 177, 277-287.

Clague, J.J., Barendregt, R., Enkin, R.J., Foit, F.F., Jr., 2003. Paleomagnetic and tephra evidence for tens of Missoula floods in southern Washington. Geology 31, 247-250.

Claire Jones, S., 2010. Palaeoenvironmental response to the $\sim 74$ ka Toba ash-fall in the Jurreru and Middle Son valleys in southern and north-central India. Quaternary Research 76, 336-350.

Clarkson, B.D., 1990. A review of vegetation development following recent ( $<450$ years) volcanic disturbance in North Island, New Zealand. New Zealand Journal of Ecology 14, 5971. 
Cole-Dai, J., Mosley-Thompson, E., Wight, S.P., Thompson, L.G., 2000. A 4100-year record of explosive volcanism from an East Antarctica ice core. Journal of Geophysical Research 105 (D19), 24431-24441.

Cole-Dai, J., Ferris, D., Lanciki, A., Savarino, J., Baroni, M., Thiemens, M.H., 2009. Cold decade (AD 1810-1819) caused by Tambora (1815) and another (1809) stratospheric volcanic eruption. Geophysical Research Letters 36, L22703. doi: 10.1029/2009GL040882.

Colman, S.M., Pierce, K.L., Birkeland, P.W., 1987. Suggested terminology for Quaternary dating methods. Quaternary Research 28, 314-318.

Coulter, S.E., Turney, C.S.M., Kershaw, P., Rule, S., 2009. The characterization and significance of a MIS 5a distal tephra on mainland Australia. Quaternary Science Reviews 28, 1825-1830.

Coulter, S.E., Pilcher, J.R., Hall, V.A., Davies, S.M., 2010. Testing the reliability of the JEOL FEGSEM 6500F electron microprobe for quantitative major element analysis of glass shards from rhyolitic tephra. Boreas 39, 163-169.

Cronin, S.J., Wallace, R.C., Neall, V.E., 1996. Sourcing and identifying andesitic tephras using major oxide titanomagnetite and hornblende chemistry, Egmont volcano and Tongariro Volcanic Centre, New Zealand. Bulletin of Volcanology 58, 33-40.

Cronin, S.J., Neall, V.E., Palmer, A.S., Stewart, R.B., 1997. Methods of identifying late Quaternary tephras on the ring plains of Ruapehu and Tongariro volcanoes, New Zealand. New Zealand Journal of Geology and Geophysics 40, 175-184.

Cronin, S.J., Neall, V.E., Lecointre, J.A., Hedley, M.J., Loganathan, P., 2003. Environmental hazards of fluoride in volcanic ash: a case study from Ruapehu volcano, New Zealand. Journal of Volcanology and Geothermal Research 121, 271-291.

Daga, R., Guevara, S.R., Sanchez, M.L., Arribere, M., 2008. Source identification of volcanic ashes by geochemical analysis of well preserved lacustrine tephras in Nahuel Huapi National Park. Applied Radiation and Isotopes 66, 1325-1336. 
Danhara, T., Yamashita, T., Iwano, H., Kasuya, M., 1992. An improved system for measuring refractive index using thermal immersion method. Quaternary International 13-14, 89-91.

Davies, S.M., Turney, C.S.M., Lowe, J.J., 2001. Identification and significance of a visible, basalt-rich Vedde Ash layer in a Late-glacial sequence on the Isle of Skye, Inner Hebrides, Scotland. Journal of Quaternary Science 16, 99-104.

Davies, S.M., Wohlfarth, B., Wastegård, S., Andersson, M., Blockley, S., Possnet, G., 2004a. Were there two Borrobol tephras during the early Lateglacial period: implications for tephrochronology. Quaternary Science Reviews 23, 581-89.

Davies, S.M., Mortensen, A.K., Baillie, M.G.L., Clausen, H.B., Gronvold, K., Hall, V.A., Johnsen, S.J., Pilcher, J.R., Steffensen, J.P., Wastegård, S., 2004b. Tracing volcanic events in the Greenland ice cores. PAGES News 12 (3), 10-11.

Davies, S.M., Elmquist, M., Bergman, J., Wohlfarth, B., Hammarlund, D., 2007. Cryptotephra sedimentation processes within two lacustrine sequences from west central Sweden. The Holocene 17, 319-330.

Davies, S.M., Wastegård, S., Rasmussen, T.L., Svensson, A., Johnsen, S.J., Steffensen, J.P., Andersen, K.K., 2008. Identification of the Fugloyarbanki tephra in the NGRIP ice core: a key tie-point for marine and ice-core sequences during the last glacial period. Journal of Quaternary Science 23, 409-414.

Davies, S.M., Larsen, G., Wastegård, S., Turney, C.S.M., Hall, V.A., Coyle, L., Thordarson, T., 2010a. Widespread dispersal of Icelandic tephra: how does the Eyjafjöll eruption of 2010 compare to past Icelandic events? Journal of Quaternary Science 25, 605-611.

Davies, S.M., Wastegård, S., Abbott, P.M., Barbante, C., Bigler, M., Johnsen, S.J., Rasmussen, T.L., Steffensen, J.P., Svensson, A., 2010b. Tracing volcanic events in the NGRIP ice-core and synchronising North Atlantic marine records during the last glacial period. Earth and Planetary Science Letters 294, 69-79. 
Davis, C.M., Fox, J.F., 2009. Sediment fingerprinting: review of the method and future improvements for allocating nonpoint source pollution. Journal of Environmental Engineering $135,490-504$.

de Brauwere, A., De Ridder, F., Pintelon, R., Schoukens, J., Dehairs, F., 2009. A comparative study of methods to reconstruct a periodic time series from an environmental proxy record. Earth-Science Reviews 95, 97-118.

de Fontaine, C.S., Kaufman, D.S., Anderson, R.S., Werner, A., Waythomas, C.F., Brown, T.A., 2007. Late Quaternary distal tephra-fall deposits in lacustrine sediments, Kenai Peninsula, Alaska. Quaternary Research 68, 64-78.

Deino, A.L., McBrearty, S., 2002. ${ }^{40} \mathrm{Ar} /{ }^{39} \mathrm{Ar}$ chronology for the Kapthurin Formation, Baringo, Kenya. Journal of Human Evolution 42, 185-210.

Deino, A.L., Scott, G.R., Saylor, B., Alene, M., Angelini, J.D., Haile-Selassie, Y., 2010. ${ }^{40} \mathrm{Ar} /{ }^{39} \mathrm{Ar}$ dating, paleomagnetism, and tephrochemistry of Pliocene strata of the hominidbearing Woranso-Mille area, west-central Afar Rift, Ethiopia. Journal of Human Evolution 58, 111-126.

de Klerk, P., Janke, W., Kühn, P., Theuerkauf, M., 2008. Environmental impact of the Laacher See eruption at a large distance from the volcano: integrated palaeoecological studies from Vorpommern (NE Germany). Palaeogeography, Palaeoclimatology, Palaeoecology 270, 196214.

de Lange, P.J., Lowe, D.J., 1990. History of vertical displacement of Kerepehi Fault at Kopouatai bog, Hauraki Lowlands, New Zealand, since c. 10700 years ago. New Zealand Journal of Geology and Geophysics 33, 277-283.

Delano, J.W., Tice, S.J., Mitchell, C.E., Goldman, D., 1995. Rhyolitic glass in Ordovician Kbentonites: a new stratigraphic tool. Geology 22, 115-118.

deMenocal, P.B., Brown, F.H., 1999. Pliocene tephra correlations between East African hominid localities, the Gulf of Aden, and the Arabian Sea. In: Agusti, J., Rook, L., Andrews, P. (Ed.), 
Hominid Evolution and Climatic Change in Europe, Volume 1. Cambridge University Press, Cambridge, pp. 23-54.

Demuro, M., Roberts, R.G., Froese, D.G., Arnold L.J., Brock, F., Bronk Ramsey, C., 2008. Optically stimulated luminescence dating of single and multiple grains of quartz from perennially frozen loess in western Yukon Territory, Canada: comparison with radiocarbon chronologies for the late Pleistocene Dawson tephra. Quaternary Geochronology 3, 346-364.

Denton, J.S., Pearce, N.J.G., 2008. Comment on "A synchronized dating of three Greenland ice cores through the Holocene" by B.M. Vinther et al.: No Minoan tephra in the 1642 B.C. layer of the GRIP ice core. Journal of Geophysical Research 113, D04303. doi:

10.1029/2007JD008970.

de Silva, S.L., Zielinski, G.A., 1998. Global influence of the AD 1600 eruption of Huaynaputina, Peru. Nature 393, 455-458.

de Vleeschouwer, F., van Vliët-Lanoé, B., Fagel, N., Richer, T., Boës, X., 2008. Development and application of high-resolution petrography on resin-impregnated Holocene peat columns to detect and analyse tephras, cryptotephras, and other materials. Quaternary International 178, 54-67.

Donoghue, S.L., Neall, V.E., Palmer, A.S., Stewart, R.B., 1997. The volcanic history of Ruapehu during the past 2 millennia based on the record of Tufa Trig tephras. Bulletin of Volcanology $59,136-146$.

Donoghue, S.L., Vallance, J., Smith, I.E.M., Stewart, R.B., 2007. Using geochemistry as a tool for correlating proximal andesitic tephras: case studies from Mt Rainier (USA) and Mt Ruapehu (New Zealand). Journal of Quaternary Science 22, 395-410.

Druce, A., 1966. Tree-ring dating of recent volcanic ash and lapilli, Mt. Egmont. New Zealand Journal of Botany 4, 3-41.

Dugmore, A.J., Newton, A.J., 1992. Thin tephra layers in peat revealed by X-radiography. Journal of Archaeological Science 19, 163-170. 
Dugmore, A.J., Larsen, G., Newton A.J., Sugden D.E., 1992. Geochemical stability of finegrained silicic Holocene tephras in Iceland and Scotland. Journal of Quaternary Science 7, 173-183.

Dugmore, A.J., Larsen, G., Newton A.J., 1995. Seven tephra isochrones in Scotland. The Holocene 5, 257-266.

Dugmore, A.J., Newton, A.J., Larsen, G., Cook, G.T., 2000. Tephrochronology, environmental change and the Norse settlement of Iceland. Environmental Archaeology 5, 21-34.

Dugmore, A.J., Larsen, G., Newton, A.J., 2004. Tephrochronology and its application to late Quaternary environmental reconstruction, with special reference to the North Atlantic islands. In: Buck, C.E.; Millard, A.R. (Eds), Tools for Constructing Chronologies: Crossing Disciplinary Boundaries. Lecture Notes in Statistics 177, pp. 173-188 (Springer, London). Dugmore, A.J., Church, M.J., Mairs, K.-A., McGovern, T.H., Perdikaris, S., Vésteinsson, O., 2007. Abandoned farms, volcanic impacts, and woodland management: revisiting Pjórsárdalur, the "Pompeii of Iceland". Arctic Anthropology 44, 1-11.

Dugmore, A.J., Gisladóttir, G., Simpson, I.A., Newton, A., 2009. Conceptual models of 1200 years of Icelandic soil erosion reconstructed using tephrochronology. Journal of the North Atlantic 2, 1-18.

Dumond, D.E., 2004. Volcanism and history on the Northern Alaska Peninsula. Arctic Anthropology 41, 112-125.

Dunbar, N.W., Zielinski, G.A., Voisins, D.T., 2003. Tephra layers in the Siple Dome and Taylor Dome ice cores, Antarctica: sources and correlations. Journal of Geophysical Research 108 (B8), 2374. doi: 10.1029/2002JB002056.

Eastwood, W.J., Tibby, J., Roberts, N., Birks, H.J.B., Lamb, H.F., 2002. The environmental impact of the Minoan eruption of Santorini (Thera): statistical analysis of palaeoecological data from Golhisar, southwest Turkey. The Holocene 12, 431-444. 
Eden, D.N., Froggatt, P.C., 1996. A 6500-year-old history of tephra deposition recorded in the sediments of Lake Tutira, eastern North Island, New Zealand. Quaternary International 34-36, 55-64.

Eden, D.N., Froggatt, P.C., McIntosh, P.D., 1992. The distribution and composition of volcanic glass in late Quaternary loess deposits of southern South Island, New Zealand, and some possible correlations. New Zealand Journal of Geology and Geophysics 35, 69-79.

Eden, D.N., Froggatt, P.C., Zheng, H., Machida, H., 1996. Volcanic glass found in Late Quaternary Chinese loess: a pointer for future studies? Quaternary International 34-36, 107111.

Eden, D.N., Palmer, A.S., Cronin, S.J., Marden, M., Berryman, K.R., 2001. Dating the culmination of river aggradation at the end of the last glaciation using distal tephra compositions, eastern North Island, New Zealand. Geomorphology 38, 133-151.

Edwards, K.J., Dugmore, A.J., Blackford, J.J., 2004. Vegetational response to tephra deposition and land-use change in Iceland: a modern analogue and multiple working hypothesis approach to tephropalynology. Polar Record 40, 113-120.

Elliott, M.B., Striewski, B., Flenley, J.R., Kirkman, J.H., Sutton, D.G., 1997. A 4300 year palynological and sedimentological record of environmental change and human impact from Wharau Road Swamp, Northland, New Zealand. Journal of the Royal Society of New Zealand 27, 401-408.

Enache, M.D., Cumming, B.F., 2006. The morphological and optical properties of volcanic glass: a tool to assess density-induced vertical migration of tephra in sediment cores. Journal of Paleolimnology 35, 661-667.

Feibel, C.S., 1999. Tephrostratigraphy and geological context in paleoanthropology. Evolutionary Anthropology 8, 87-100. 
Fiacco, R.J., Jr., Thordarson, T., Germani, M.S., Self, S., Palais, J.M., Whitlow, S., Grootes, P.M. 1994. Atmospheric aerosol loading and transport due to the 1783-84 Laki eruption in Iceland, interpreted from ash particles and acidity in the GISP2 ice core. Quaternary Research 42, 231240.

Fisher, R.V., Schminke, H.-U., 1984. Pyroclastic Rocks. Springer, Berlin, pp. 1-472.

Fiske, R.S., Rose, T.R., Swanson, D.A., Champion, D.E., McGeehin, J.P., 2009. Kulanaokuaiki Tephra (ca. A.D. 400-1000): newly recognized evidence for highly explosive eruptions at Kilauea Volcano, Hawai'i. Geological Society of America Bulletin 121, 712-728.

Froese, D.G., Zazula, G.D., Reyes, A.V., 2006, Seasonality of the late Pleistocene Dawson tephra and exceptional preservation of a buried riparian surface in central Yukon Territory, Canada: Quaternary Science Reviews 25, 1542-1551.

Froese, D.G., Lowe, D.J., Knott, J., Slate, J.L., 2008. Preface - global tephra studies. Quaternary International 178, 1-3.

Froese, D.G., Zazula, G.D., Wesgate, J.A., Preece, S.J., Sanborn, P.T., Reyes, A.V., Pearce, N.J.G., 2009. The Klondike goldfields and Pleistocene environments of Beringia. GSA Today 19, 4-10.

Froggatt, P.C., 1983. Toward a comprehensive Upper Quaternary tephra and ignimbrite stratigraphy in New Zealand using electron microprobe analysis of glass shards. Quaternary Research 19, 188-200.

Froggatt, P.C., 1992. Standardization of the chemical analysis of tephra deposits. Report of the ICCT working group. Quaternary International 13-14, 93-96.

Froggatt, P.C., Gosson, G.J., 1982. Techniques for the preparation of tephra samples for mineral or chemical analysis and radiometric dating. Geology Department, Victoria University of Wellington Publication 23, 1-12. 
Froggatt, P.C., Lowe, D.J., 1990. A review of late Quaternary silicic and some other tephra formations from New Zealand: their stratigraphy, nomenclature, distribution, volume, and age. New Zealand Journal of Geology and Geophysics 33, 89-109.

Froggatt, P.C., Nelson, C.S., Carter, L., Griggs, G., Black, K.P., 1986. An exceptionally large late Quaternary eruption from New Zealand. Nature 319, 578-582.

Gale, S.J., 2009. Event chronostratigraphy: a high-resolution tool for dating the recent past. Quaternary Geochronology 4, 391-399.

Gehrels, M.J., Lowe, D.J., Hazell, Z.J., Newnham, R.M., 2006. A continuous 5300-year Holocene cryptotephrostratigraphic record from northern New Zealand and implications for tephrochronology and volcanic-hazard assessment. The Holocene 16, 173-187.

Gehrels, M.J., Newnham, R.M., Lowe, D.J., Wynne, S., Hazell, Z.J., Caseldine, C., 2008. Towards rapid assay of cryptotephra in peat cores: review and evaluation of various methods. Quaternary International 178, 68-84.

Giaccio, B., Isaia, R., Fedele, F.G., Di Canzio, E., Hoffecker, J., Ronchitelli, A., Sinitsyn, A.A., Anikovich, M., Lisitsyn, S.N., Popov, V.V., 2008. The Campanian Ignimbrite and Codola tephra layers: two temporal/stratigraphic markers for the Early Upper Paleolithic in southern Italy and eastern Europe. Journal of Volcanology and Geothermal Research 177, 208-226. Giles, T.M., Newnham, R.M., Lowe, D.J., Munro, A.J., 1999. Impact of tephra fall and environmental change: a 1000 year record from Matakana Island, Bay of Plenty, North Island, New Zealand. Geological Society (London) Special Publications 161, 11-26

Gomez, B., Carter, L., Trustrum, N.A., 2007. A 2400 yr record of natural events and anthropogenic impacts in intercorrelated terrestrial and marine sediment cores: Waipaoa sedimentary system, New Zealand. Geological Society of America Bulletin 119, 1415-1432.

Gonzalez, S., Jones, J.M., Williams, D.L., 1999. Characterization of tephras using magnetic properties: an example from SE Iceland. Geological Society, London, Special Publications $161,125-145$. 
Goslar, T., Van Der Knaap, W.O., Kamenik, C., Van Leeuwen, J.F.N., 2009. Free-shape ${ }^{14}$ C agedepth modelling of an intensively dated modern peat profile. Journal of Quaternary Science 24, 481-499.

Grattan, J., 2006. Aspects of Armageddon: an exploration of the role of volcanic eruptions in human history and civilization. Quaternary International 151, 10-18.

Grattan, J., Gilbertson, D., Charman, D., 1999. Modelling the impact of Icelandic volcanic eruptions upon the prehistoric societies and environment of northern and western Britain. Geological Society (London) Special Publications 161, 109-124.

Green, J.D., Lowe, D.J., 1985. Stratigraphy and development of c. 17000 year old Lake Maratoto, North Island, New Zealand, with some inferences about postglacial climatic change. New Zealand Journal of Geology and Geophysics 28, 675-699.

Hajdas, I., Lowe, D.J., Newnham, R.M., Bonani, G., 2006. Timing of the late-glacial climate reversal in the Southern Hemisphere using high-resolution radiocarbon chronology for Kaipo bog, New Zealand. Quaternary Research 65, 340-345.

Hall, V.A., Pilcher, J.R., 2002. Late-Quaternary Icelandic tephras in Ireland and Great Britain: detection, characterization and usefulness. The Holocene 12, 223-230.

Hall, V.A., Mauquoy, D., 2005. Tephra-dated climate- and human-impact studies during the last 1500 years from a raised bog in central Ireland. The Holocene 15, 1086-1093.

Hamann, Y., Wulf, S., Ersoy, D., Ehrmann, W., Aydar, E., Schmiedl, G., 2010. First evidence of a distal early Holocene ash layer in eastern Mediterranean deep-sea sediments derived from the Anatolian volcanic province. Quaternary Research 73, 497-506.

Hammer, O., Harper, D.A.T., Ryan, P.D., 2001. PAST: paleontological statistics software package for education and data analysis. Palaeontologia Electronica 4 (1), article 4, 9 pp. http://palaeo-electronica.org/2001_1/past/issue1_01.htm

Hammer, C.U., Kurat, G., Hoppe, P., Grum, W., Clausen, H.B., 2003. Thera eruption date 1645 BC confirmed by new ice core data? In: Bietak, M. (Ed.), The Synchronisation of Civilisations 
in the Eastern Mediterranean in the Second Millennium B.C. II. , Austrian Academy of Science, Vienna, pp. 87-94.

Hammond, A., Ward, W.T., 2001. Replicate means of rhyolitic tephras. In: Lowe, D.J., Cooke, P.J., Pallentin, A. (Eds.), Abstracts and Programme, Geological Society of New Zealand Annual Conference 27-29 November, Hamilton. Geological Society of New Zealand Miscellaneous Publication 110A, p. 53.

Harangi, S., Mason, P.R.D., Lukacs, R., 2005. Correlation and petrogenesis of silicic pyroclastic rocks in the northern Pannonian Basin, eastern-central Europe: in situ trace element data of glass shards and mineral chemical constraints. Journal of Volcanology and Geothermal Research 143, 237-257.

Harris, D.M., Rose, W.I., Jr., Roe, R., Thompson, M.R., 1981. Radar observations of ash eruptions. In: Lipman, P.W., Mullineaux, D.R. (Ed.), The 1980 Eruptions of Mount St. Helens, Washington. Geological Survey Professional Paper 1250, 323-341.

Hart, W.K., Waltr, R.C., WoldeGabriel, G., 1992. Tephra sources and correlations in Ethiopia: application of elemental and neodymium isotope data. Quaternary International 13-14, 77-86.

Haslett, J., Parnell, A., 2008.A simple monotone process with application to radiocarbon dated depth chronologies. Journal of the Royal Statistical Society Series C (Applied Statistics) 57, 120.

Hay, R.L., 1992. Potassium-argon dating of Bed I, Olduvai Gorge, 1961-1972. Quaternary International 13-14, 31-36.

Hayashida, A., Kamata, H., Danhara, T., 1996. Correlation of widespread tephra deposits based on paleomagnetic directions: link between a volcanic field and sedimentary sequences in Japan. Quaternary International 34-36, 89-98.

Haynes, J.T., Melson, W.G., Kunk, M.J., 1995. Composition of biotite phenocrysts in Ordovician tephras casts doubt on the proposed trans-Atlantic correlation of the Millbrig K-bentonite (United States) and the Kinnekulle K-bentonite (Sweden). Geology 23, 847-850. 
Hayward, C., submitted for publication. High spatial resolution electron probe microanalysis of tephras and melt inclusions without beam-induced chemical modification. The Holocene.

Heegaard, E., Birks, H.J.B., Telford, R.J., 2005. Relationships between calibrated ages and depth in stratigraphical sequences: an estimation procedure by mixed-effect regression. The Holocene 15, 612-618.

Heiken, G., Wohletz, K., 1991. Fragmentation processes in explosive volcanic eruptions. In: R.V. Fisher, R.V., Smith, G.A. (Eds), Sedimentation in Volcanic Settings. Society of Economic Paleontologists and Mineralogists, Special Publication 45, pp. 19-26.

Higham, T.F.G., Hogg, A.G. 1997. Evidence for late Polynesian colonisation of New Zealand: University of Waikato radiocarbon measurements. Radiocarbon 39, 149-192.

Higham, T.F.G., Anderson, A.J., Jacomb, C. 1999. Dating the first New Zealanders: the chronology of Wairau Bar. Antiquity 73, 420-427.

Higham, T.F.G., Hedges, R.E.M., Anderson, A.J., Bronk Ramsey, C., Fankhauser, B., 2004. Problems associated with the AMS dating of small bone samples: the question of the arrival of Polynesian rats to New Zealand. Radiocarbon 46, 207-218.

Hillenbrand, C.-D., Moreton, S.G., Caburlotto, A., Pudsey, C.J., Lucchi, R.G., Smellie, J.L., Benetti, S., Grobe, H., Hunt, J.B., Larter, R.D., 2008. Volcanic time-markers for Marine Isotopic Stages 6 and 5 in Southern Ocean sediments and Antarctic ice cores: implications for tephra correlations between palaeoclimatic records. Quaternary Science Reviews 27, 518-540. Hodder, A.P.W., 1981. Titanomagnetites in tephras: some implications from crystal field theory. Chemical geology 32, 103-118.

Hodder, A.P.W., de Lange, P.J., Lowe, D.J., 1991. Dissolution and depletion of ferromagnesian minerals from Holocene tephras in an acid bog, New Zealand, and implications for tephra correlation. Journal of Quaternary Science 6,195-208. 
Hodgson, D.A., Dyson, C.L., Jones, V.J., Smellie, J.L., 1998. Tephra analysis of sediments from Midge Lake (South Shetland Islands) and Sombre Lake (South Orkney Islands), Antarctica. Antarctic Science 10, 13-20.

Hogg, A.G., McCraw, J.D., 1983. Late Quaternary tephras of Coromandel Peninsula, North Island, New Zealand: a mixed peralkaline and calcalkaline tephra sequence. New Zealand Journal of Geology and Geophysics 26, 163-187.

Hogg, A.G., Higham, T.F.G., Lowe, D.J., Palmer, J., Reimer, P., Newnham, R.M., 2003. A wiggle-match date for Polynesian settlement of New Zealand. Antiquity 77, 116-125.

Hogg, A.G., Palmer, J., Boswijk, G., Ramsey, C.B., Sparks, R., 2009. Assessment of the integrity of the Southern Hemisphere ${ }^{14} \mathrm{C}$ calibration curve and its extension from AD 785 to $195 \mathrm{BC}$, with a new preliminary calendar age for the Taupo Tephra. In: Cortes, G., Vandergoes, M., Bostock, H. (Eds), Past Climates Meeting, 15-17 ${ }^{\text {th }}$ May, Wellington. GNS Science Miscellaneous Series 23, p. 30.

Holdaway, R.N., 1996. Arrival of rats in New Zealand. Nature 384, 225-226.

Holt, K., Wallace, R.C., Neall, V.E., Kohn, B.P., Lowe, D.J., 2010. Quaternary tephra marker beds and their potential for palaeoenvironmental reconstruction on Chatham Islands east of New Zealand, southwest Pacific Ocean. Journal of Quaternary Science 25, 1169-1178.

Horrocks, M., Ogden, J., 1998. The effects of the Taupo Tephra eruption of c. 1718 BP on the vegetation of Mt Hauhangatahi, central North Island, New Zealand. Journal of Biogeography $25,649-660$.

Horrocks, M., Deng, Y., Ogden, J., Alloway, B.V., Nichol, S.L., Sutton, D.G., 2001. High spatial resolution of pollen and charcoal in relation to the $c .600$ year BP Kaharoa Tephra: implications for Polynesian settlement of Great Barrier Island, northern New Zealand. Journal of Archaeological Science 28, 153-168. 
Horrocks, M., Nicol, S.L., D’Costa, D.M., Augustinus, P., Shane, P.A.R., Middleton, A., 2007. A late Quaternary record of natural change and human impact from Rangihoua Bay, Bay of Islands, northern New Zealand. Journal of Coastal Research 23, 592-604.

Houghton, B.F., Wilson, C.J.N., Pyle, D.M., 2000. Pyroclastic fall deposits. In: Sigurdsson, H. (Ed.), Encyclopaedia of Volcanoes. Academic Press, San Diego, CA, pp. 555-570.

Howorth, R., Rankin, P.C. 1975. Multi-element characterisation of glass shards from stratigraphically correlated rhyolitic tephra units. Chemical Geology 15, 239-250.

Huff, W.D., 2008. Ordovician K-bentonites: issues in interpreting and correlating ancient tephras. Quaternary International 178, 276-287.

Hughen, K., Southon, J., Lehman, S., Bertrand, C., Turnbull, J., 2006. Marine-derived ${ }^{14}$ C calibration and activity record for the past 50,000 years updated from the Cariaco Basin. Quaternary Science Reviews 25, 3216-3227.

Hunt, J.B., Hill, P. G., 1993. Tephra geochemistry: a discussion of some persistent analytical problems. The Holocene 3, 271-278.

Hunt, J.B., Hill, P.G., 1996. An inter-laboratory comparison of the electron probe microanalysis of glass geochemistry. Quaternary International 34-36, 229-241.

Hunt, J.B., Hill, P.G., 2001. Tephrological implications of beam size-sample-size effects in electron microprobe analysis of glass shards. Journal of Quaternary Science 16, 105-117.

Hunt, J.B., Najman, Y.M.R., 2003. Tephrochronological and tephrostratigraphical potential of Pliocene-Pleistocene volcaniclastic deposits in the Japan Forearc, ODP Leg 186. In: Suyehiro, K., Sacks, I.S., Acton, G.D., Oda, M. (Ed.), Proceedings of the Ocean Drilling Program, Scientific Results 186, 1-29.

Hurst, T., Smith, W., 2004. A Monte Carlo methodology for modelling ashfall hazards. Journal of Volcanology and Geothermal Research 138, 393-403.

Hurst, T., Smith, W., 2010. Volcanic ashfall in New Zealand - probabilistic hazard modelling for multiple sources. New Zealand Journal of Geology and Geophysics, 53: 1-14. 
Inoue, Y., Baasansuren, J., Watanabe, M., Kamei, H., Lowe, D.J., 2009. Interpretation of pre-AD 472 Roman soils from physicochemical and mineralogical properties of buried tephric paleosols at Somma Vesuviana ruin, southwest Italy. Geoderma 152, 243-251.

Jenkins, S.F., Magill, C.R., McAneney, K.J., 2007. Multi-stage volcanic events: a statistical investigation. Journal of Volcanology and Geothermal Research 161, 275-288.

Jensen, B.J.L., Froese, D.G., Preece, S.J., Westgate, J.A., Stachel, T., 2008. An extensive middle to late Pleistocene tephrochronologic record from east-central Alaska. Quaternary Science Reviews 27, 411-427.

Johnston, D.M., Houghton, B.F., Neall, V.E., Ronan, K.R., Paton, D., 2000. Impacts of the 1945 and 1995-1996 Ruapehu eruptions, New Zealand: an example of increasing societal vulnerability. Geological Society of America Bulletin 112, 720-726.

Jordan, B.R., Sigurdsson, H., Carey, S.N., Rogers, R., Ehrenborg, J., 2006. Geochemical correlation of Caribbean Sea tephra layers with ignimbrites in Central America. Geological Society of America Special Papers 402, 175-208.

Julian, S.R., Westgate, J.A., Daniels, J.M., Rancourt, D.G., Sullivan, P., 1988. A comparison of the titanomagnetites produced by several volcanoes in Iceland. Hyperfine Interactions 41, 807810.

Juvigné, E.T., Porter, S.C., 1985. Mineralogical variations within two widespread Holocene tephra layers from Cascade Range volcanoes, U.S.A. Géographie Physique et Quaternaire 39, $7-12$.

Katsuta, N., Takano, M., Kawakami, S., Togami, S., Fukusawa, H., Kumazawa, M., Yasuda, Y., 2007. Advanced micro-XRF method to separate sedimentary rhythms and event layers in sediments: its application to lacustrine sediment from Lake Suigetsu, Japan. Journal of Paleolimnology 37, 259-271.

Keenan, D.J., 2003. Volcanic ash retrieved from the GRIP ice core is not from Thera. Geochemistry, Geophysics, Geosystems 4, 1097. doi: 10.1029/2003GC00068. 
Kekonen, T., Moore, J., Perämäki, P., Martma, T., 2005. The Icelandic Laki volcanic tephra layer in the Lomonosovfonna ice core, Svalbard. Polar Record 24, 33-40.

Kennett, J., 1981. Marine tephrochronology. In: Emiliani, C. (Ed.), The Oceanic Lithosphere, Wiley, New York, pp. 1373-1436.

Kilian, R., Biester, H., Behrmann, J., Baeza, O., Fesq-Martin, M., Hohner, M., Schimpf, D., Friedman, A., Mangini, A., 2006. Millennium-scale volcanic impact on a superhumid and pristine ecosystem. Geology 34, 609-612.

Kimber, R.W.L., Kennedy, N.M., Milnes, A.R., 1994. Amino acid racemisation dating of a 140000 year old tephra-loess-paleosol sequence on the Mamaku Plateau near Rotorua, New Zealand. Australian Journal of Earth Sciences 41, 19-26.

Kirkbride, M.P., Dugmore, A.J., 2006. Responses of mountain ice caps in central Iceland to Holocene climate change. Quaternary Science Reviews 25, 1692-1707.

Kirkbride, M.P., Dugmore, A.J., 2008. Two millennia of glacier advances from southern Iceland dated by tephrochronology. Quaternary Research 70, 398-411.

Knott, J.R., Sarna-Wojcicki, A.M., Montañez, I.P., Wan, E., 2007. Differentiating the Bishop ash bed and related tephra layers by elemental-based similarity coefficients of volcanic glass shards using solution inductively coupled plasma-mass spectrometry (S-ICP-MS). Quaternary International 166, 79-86.

Knox, R.W.O’B., 1993. Tephra layers as precise chronostratigraphic markers. Geological Soviety, London, Special Publications 70, 169-186.

Kobayashi, T., 2010. Active volcanoes in Kyushu. In: Moriwaki, H., Lowe, D.J. (eds) Intraconference field trip guides. International Field Conference on Tephrochronology, Volcanism and Human Activity, Kirishima, Japan (9-17 May). INQUA International Focus Group on Tephrochronology and Volcanism (INTAV), pp. 36-43.

Kobayashi, T., Nairn, I.A., Smith, V., Shane, P.A.R., 2005. Proximal stratigraphy and event sequence of the c. 5600 cal. yr BP Whakatane rhyolite eruption episode from Haroharo 
volcano, Okataina Volcanic Centre, New Zealand. New Zealand Journal of Geology and Geophysics 48, 471-490.

Kohn, B.P., 1970. Identification of New Zealand tephra-layers by emission spectrographic analysis of their titanomagnetites. Lithos 3, 361-368.

Kohn, B.P., Neall, V.E., 1973. Identification of late Quaternary tephras for dating Taranaki lahar deposits. New Zealand Journal of Geology and Geophysics 16, 781-792.

Kohn, B.P., Topping, W.W., 1978. Time-space relationships between late Quaternary rhyolitic and andesitic volcanism in the southern Taupo Volcanic Zone, New Zealand. Geological Society of America Bulletin 89, 1265-1271.

Kohn B.P., Pillans B.J., McGlone, M.S., 1992. Zircon fission track age for middle Pleistocene Rangitawa Tephra, New Zealand. Palaeogeography, Palaeoclimatology, Palaeoecology 95, 7394.

Kratzmann, D.J., Carey, S., Scasso, R., Naranjo, J.-A., 2009. Compositional variations and magma mixing in the 1991 eruptions of Hudson volcano, Chile. Bulletin of Volcanology 71, 419-439.

Kristjánsdóttir, G.B., Stoner, J.S., Jennings, A.E., Andrews, J.T., Grönvold, K., 2007. Geochemistry of Holocene cryptotephras from the North Iceland Shelf (MD99-2269): intercalibration with radiocarbon and paleomagnetic chronostratigraphies. The Holocene 17, $155-176$

Kuehn, S.C., Foit, F.F., Jr., 2006. Correlation of widespread Holocene and Pleistocene tephra layers from Newberry Volcano, Oregon, USA, using glass compositions and numerical analysis. Quaternary International 148, 113-137.

Kuehn, S.C., Froese, D.G., 2010. Tephra from ice - a simple method to routinely mount, polish, and quantitatively analyze sparse fine particles. Microscopy and Microanalysis 16, 218-225. 
Kuehn, S.C., Negrini, R.M., 2010. A 250 k.y. record of Cascade arc pyroclastic volcanism from late Pleistocene lacustrine sediments near Summer Lake, Oregon, USA. Geosphere 6, 397429.

Kuehn, S.C., Froese, D.G., Carrara, P.E., Foit, F.F., Jr., Pearce, N.J.G., Rotheisler, P., 2009. Major- and trace-element characterization, expanded distribution, and a new chronology for the latest Pleistocene Glacier Peak tephras in western North America. Quaternary Research 71, 201-216.

Kuehn, S.C., Froese, D.G., Shane, P.A.R., Davies, S., Alloway, B.V., 2010. The INTAV intercomparison of tephrochronology laboratories. Abstracts, International Field Conference on Tephrochronology, Volcanism and Human Activity, Kirishima, Japan (9-17 May). INQUA International Focus Group on Tephrochronology and Volcanism (INTAV), p. 47.

Kurbatov, A.V., Zielinski, G.A., Dunbar, N.W., Mayewski, P.A., Meyerson, E.A., Sneed, S.., Taylor, K.C., 2006. A 12,000 year record of explosive volcanism in the Siple Dome Ice Core, West Antarctica. Journal of Geophysical Research 111, D12307. doi: 10.1029/2005JD006072.

Lacasse, C., 2001. Influence of climate variability on the atmospheric transport of Icelandic tephra in the subpolar North Atlantic. Global and Planetary Change 29, 31-55.

Lacasse, C., van den Bogaard, P., 2002. Enhanced airborne dispersal of silicic tephras during the onset of Northern Hemisphere glaciations, from 6 to 0 Ma records of explosive volcanism and climate change in the subpolar North Atlantic. Geology 30, 623-626.

Lacasse, C., Werner, R., Paterne, M., Sigurdson, H., Carey, S., Pinte, G., 1998. Long-range transport of Icelandic tephra to the Irminger Basin, Site 919. In: Saunders, A.D., Larsen, H.C., Wise, S.W., Jr. (Ed.), Proceedings of the Ocean Drilling Program, Scientific Results 152, 5165.

Lakeman, T.R., Clague, J.J., Menounos, B., Osborn, G.D., Jensen, B.J.L., Froese, D.G., 2008. Holocene tephras in lake cores from northern British Columbia, Canada. Canadian Journal of Earth Sciences 45, 935-947. 
Laluraj, C.M., Krishnan, K.P., Thamban, M., Mohan, R., Naik, S.S., D’Souza, W., Ravindra, R., Chaturvedi, A., 2009. Origin and characterisation of microparticles in an ice core from the Central Dronning Maud Land, East Antarctica. Environmental Monitoring and Assessment $149,377-383$.

Lanphere, M., Champion, D., Clynne, M. A., Lowenstern, J. B., Sarna-Wojcicki, A. M., Wooden, J. L., 2004. Age of the Rockland tephra, western USA. Quaternary Research 62, 94-104.

Lanphere, M., Champion, D., Melluso, L., Morra, V., Perrotta, A., Scarpati, C., Tedesco, D., Calvert, A., 2007. ${ }^{40} \mathrm{Ar} /{ }^{39} \mathrm{Ar}$ ages of the $A D 79$ eruption of Vesuvius, Italy. Bulletin of Volcanology 69, 259-263.

Larick, R., Ciochon, R.L., Zaim, Y., Sudijono, Suminto, Rizal, Y., Aziz, F., Reagani, M., Heizler, M., 2001. Early Pleistocene ${ }^{40} \mathrm{Ar} /{ }^{39} \mathrm{Ar}$ ages for Bapang Formation hominins, central Java, Indonesia. Proceedings of the National Academy of Sciences 98, 4866-4871.

Larsen, G., Eiríksson, J., 2007. Late Quaternary terrestrial tephrochronology of Iceland frequency of explosive eruptions, type and volume of tephra deposits. Journal of Quaternary Science 23, 109-120.

Larsen, G., Gudmundsson, M.T., Björnsson, H., 1998. Eight centuries of periodic volcanism at the center of the Iceland hotspot revealed by glacier tephrostratigraphy. Geology 26, 943-946.

Leahy, K., 1997. Discrimination of reworked pyroclastics from primary tephra-fall tuffs: a case study using kimberlites of Fort a la Corne, Saskatchewan, Canada. Bulletin of Volcanology $59,65-71$.

Lees, C.M., Neall, V.E., 1993. Vegetation response to volcanic eruptions on Egmont volcano, New Zealand, during the last 1500 years. Journal of the Royal Society of New Zealand 23, 91127.

Lian, O., Shane, P., 2000. Optical dating of paleosols bracketing the widespread Rotoehu tephra, North Island, New Zealand. Quaternary Science Reviews 19, 1649-1662. 
Lim, C., Ikehara, K., Toyoda, K., 2008. Cryptotephra detection using high-resolution trace element analysis of Holocene marine sediments, southwest Japan. Geochimica et Cosmochimica Acta 72, 5022-5036.

Lindsay, J., Marzocchi, W., Jolly, G., Constantinescu, R., Selva, J., Sandri, L., 2009. Towards real-time eruption forecasting in the Auckland Volcanic Field: application of BET_EF during the New Zealand National Disaster Exercise 'Ruaumoko'. Bulletin of Volcanology 72, 185204.

Litchfield, N.J., Berryman, K.R., 2005. Correlation of fluvial terraces within the Hikurangi Margin, New Zealand: implications for climate and baselevel controls. Geomorphology 68, 291-313.

Lowe, D.J., 1985. Application of impulse radar to continuous profiling of tephra-bearing lake sediments and peats: an initial evaluation. New Zealand Journal of Geology and Geophysics $28,667-674$.

Lowe, D.J., 1986a. Revision of the age and stratigraphic relationships of Hinemaiaia Tephra and Whakatane Ash, North Island, New Zealand, using distal occurrences in organic deposits. New Zealand Journal of Geology and Geophysics 29, 61-73.

Lowe, D.J., 1986b. Controls on the rates of weathering and clay mineral genesis in airfall tephras: a review and New Zealand case study. In: Colman, S.M., Dethier, D.P. (Eds), Rates of Chemical Weathering of Rocks and Minerals. Academic Press, Orlando, pp. 265-330.

Lowe, D.J., 1988a. Late Quaternary volcanism in New Zealand: towards an integrated record using distal airfall tephras in lakes and bogs. Journal of Quaternary Science 3, 111-120.

Lowe, D.J., 1988b. Stratigraphy, age, composition, and correlation of late Quaternary tephras interbedded with organic sediments in Waikato lakes, North Island, New Zealand. New Zealand Journal of Geology and Geophysics 31, 125-165.

Lowe, D.J. 1990. Tephra studies in New Zealand: an historical review. Journal of the Royal Society of New Zealand 20, 119-150. 
Lowe, D.J., 2008a. Globalisation of tephrochronology - new views from Australasia. Progress in Physical Geography 32, 311-335.

Lowe, D.J., 2008b. Uncertainty in tephrochronology. SUPRAnet consortium workshop 'Studying uncertainty in palaeoclimate reconstruction', Sheffield, U.K., 23-27 June 2008. Presentation available at http://caitlinbuck.staff.shef.ac.uk/SUPRAnet/

Lowe, D.J., de Lange, W.P., 2000. Volcano-meteorological tsunamis, the $c$. AD 200 Taupo eruption (New Zealand) and the possibility of a global tsunami. The Holocene 10, 401-407.

Lowe, D.J., Higham, T.F.G., 1998. Hit-or-myth? Linking a 1259 AD acid spike with an Okataina eruption. Antiquity 72, 427-431.

Lowe, D.J., Hogg, A.G. 1995. Age of the Rotoehu Ash. New Zealand Journal of Geology and Geophysics 38, 399-402.

Lowe, D.J., Hunt, J.B., 2001. A summary of terminology used in tephra-related studies. Les Dossiers de l'Archaéo-Logis 1, 17-22.

Lowe, D.J., Newnham, R.M., 2004. Role of tephra in dating Polynesian settlement and impact, New Zealand. PAGES News 12 (3), 5-7.

Lowe, D.J., Green, J.D., Northcote, T.G., Hall, K.J., 1997. Holocene fluctuations of a meromictic lake in southern British Columbia. Quaternary Research 48, 100-113.

Lowe, D.J., McFadgen, B.G., Higham, T.F.G., Hogg, A.G., Froggatt, P.C., Nairn, I.A., 1998. Radiocarbon age of the Kaharoa Tephra, a key marker for late-Holocene stratigraphy and archaeology in New Zealand. The Holocene 8, 487-495.

Lowe, D.J., Newnham, R.M., Ward, C.M., 1999. Stratigraphy and chronology of a 15 ka sequence of multi-sourced silicic tephras in a montane peat bog, eastern North Island, New Zealand. New Zealand Journal of Geology and Geophysics 42, 565-579.

Lowe, D.J., Newnham, R.M., McFadgen, B.G., Higham, T.F.G., 2000. Tephras and New Zealand archaeology. Journal of Archaeological Science 27, 859-870. 
Lowe, D.J., Tippett, J.M., Kamp, P.J.J., Liddell, I.J., Briggs, R.M., Horrocks, J.L., 2001. Ages on weathered Plio-Pleistocene tephra sequences, western North Island, New Zealand. Les Dossiers de l'Archeo-Logis 1, 45-60.

Lowe, D.J., Newnham, R.M., McCraw, J.D. 2002. Volcanism and early Maori society in New Zealand. In: Torrence, R., Grattan, J. (Eds), Natural Disasters and Cultural Change. Routledge, London, pp. 126-161.

Lowe, D.J., Shane, P.A.R., Alloway, B.V., Newnham, R.M., 2008a. Fingerprints and age models for widespread New Zealand tephra marker beds erupted since 30,000 years ago: a framework for NZ-INTIMATE. Quaternary Science Reviews 27, 95-126.

Lowe, D.J., Blaauw, M., Bateman, M.D., Buck, C.E., Newnham, R.M., 2009. Introducing SUPRAnet and some implications for age modelling in the Australasian INTIMATE project. In: Cortes, G., Vandergoes, M., Bostock, H. (Eds), Past Climates Meeting, 15-17 ${ }^{\text {th }}$ May, Wellington. GNS Science Miscellaneous Series 23, p. 38.

Lowe, D.J., Wilson, C.J.N., Newnham, R.M., Hogg, A.G., 2010. Dating the Kawakawa/Oruanui eruption: comment on "Optical luminescence dating of a loess section containing a critical tephra marker horizon, SW North Island of New Zealand” by R. Grapes et al. Quaternary Geochronology 5, 493-496.

Lowe, J.J., Blockley, S.P.E., Trincardi, F., Asioli, A., Cattaneo, A., Matthews, I.P., Pollard, A.M., Wulf, S., 2007. Age modelling of late Quaternary marine sequences in the Adriatic: towards improved precision and accuracy using volcanic event stratigraphy. Continental Shelf Research 27, 560-582.

Lowe, J.J., Rasmussen, S.O., Björck, S., Hoek, W.Z., Steffensen, J.P., Walker, M.J.C., Yu, Z., INTIMATE group, 2008b. Synchronisation of palaeoenvironmental events in the North Atlantic region during the Last Termination: a revised protocol recommended by the INTIMATE group. Quaternary Science Reviews 27, 6-17. 
Machida, H., 2002. Volcanoes and tephras in the Japan area. Global Environmental Research 6, $19-28$.

Machida, H., 2010. Outline of tectonic setting and explosive volcanism of southern Kyushu. In: Moriwaki, H., Lowe, D.J. (Ed.), Intra-conference field trip guides. INTAV International Field Conference on Tephrochronology, Volcanism, and Human Activity, Kirishima, Japan (9-17 May). INQUA International Focus Group on Tephrochronology and Volcanism (INTAV), pp. $11-35$.

Mackie, E., Davies, S.M., Turney, C.S.M., Dobbyn, K., Lowe, J.J., 2002. The use of magnetic separation techniques to detect basaltic microtephra in glacial-interglacial transition (LGIT; 15-10 ka cal. BP) sediment sequences in Scotland. Scottish Journal of Geology 38, 21-30.

Mangerud, J., Lie, S.E., Furnes, H., Kristiansen, I.L., Lømo, L., 1984. A Younger Dryas ash bed in western Norway, and its possible correlations with tephra in cores from the Norwegian Sea and the North Atlantic. Quaternary Research 21, 85-104.

Manville, V., Wilson, C.J.N., 2004. Vertical density currents: a review of their potential role in the deposition and interpretation of deep-sea ash layers. Journal of the Geological Society 161, 947958.

Manville, V.; Wilson, C.J.N., 2006. The 26.5 ka Oruanui eruption, New Zealand: a review of the roles of volcanism and climate in the post-eruptive sedimentary response. New Zealand Journal of Geology and Geophysics 47, 525-547.

Maria, A., Carey, S., 2002. Using fractal analysis to quantitatively characterize the shapes of volcanic particles. Journal of Geophysical Research 107(B11), 2283. doi:

10.1029.2001JB000822.

Marshall, M., Lamb, H., Davies, S., Nakagawa, T., Metcalfe, S., Jones, M., Boyle, J., 2010. Highresolution XRF and X-radiographic core scanning: a powerful tool in palaeolimnology. Abstracts, ITRAX 2010 Conference “Applications, Innovations and Future Developments”, Lipari, Italy (12-14 April), p.21. 
Mason, B.G., Pyle, D.M., Oppenheimer, C., 2004. The size and frequency of the largest explosive eruptions on Earth. Bulletin of Volcanology 66, 735-748.

Matsu'ura, T., Miyagi, I., Furusawa, A., submitted for publication. Late Quaternary cryptotephra detection and correlation in loess in northeastern Japan using cummingtonite geochemistry. Quaternary Research

McGlone, M.S., Toppping, W.W., 1983. Late Quaternary vegetation, Tongariro region, central North Island, New Zealand. New Zealand Journal of Botany 21, 53-76.

McGlone, M.S., J.M., 1999. Dating initial Maori environmental impact in New Zealand. Quaternary International 59, 5 -16.

McHenry, L.J., 2005. Phenocryst composition as a tool for correlating fresh and altered tephra Bed 1, Olduvai Gorge, Tanzania. Stratigraphy 2, 101-115.

Merkt, J., Müller, H., Knabe, W., Müller, P., Weiser, T., 1993. The early Holocene Saksunarvatn tephra found in lake sediments in NW Germany. Boreas 22, 93-100.

Merrill, R.T., McFadden, P.L., 2005. The use of magnetic field excursions in stratigraphy. Quaternary Research 63, 232-237.

Miller, T.P., Casadevall, T.J., 2000. Volcanic ash hazards to aviation. In: Sigurdsson, H. (Ed.)., Encyclopaedia of Volcanoes. Academic Press, San Diego, CA, pp. 915-930.

Mills, M.J., 2000. Volcanic aerosol and global atmospheric effects. In: Sigurdsson, H. (Ed.), Encyclopaedia of Volcanoes. Academic Press, San Diego, CA, pp. 931-943.

Milne, J.D.G., 1973. Mount Curl Tephra, a 230000-year-old marker bed in New Zealand, and its implications for Quaternary chronology. New Zealand Journal of Geology and Geophysics 16, 519-532.

Mizota, C., Kusakabe, M., Noto, M., 1990. Oxygen isotope composition of quartz in soils developed on late Quaternary volcanic ashes in Japan. Geoderma 46, 319-327. 
Molloy, C., Shane, P., Augustinus, P., 2009. Eruption recurrence rates in a basaltic volcanic field based on tephra layers in maar sediments: implications for hazards in the Auckland volcanic field. Geological Society of America Bulletin 121, 1666-1677.

Morgan, G.B., London, D. 1996. Optimising the electron microprobe analysis of hydrous alkali aluminosilicate glasses. American Mineralogist, 81, 1176-1185.

Morgan, G.B., London, D., 2005. Effect of current density on the electron microprobe analysis of alkali aluminosilicate glasses. American Mineralogist, 90, 1131-1138.

Moriwaki, H., Nakamura, N., Sangawa, T., 2010a. Tephras and archaeology in southern Kyushu. In: Moriwaki, H., Lowe, D.J. (Ed.), Intra-conference field trip guides. International Field Conference on Tephrochronology, Volcanism, and Human Activity, Kirishima, Japan (9-17 May). INQUA International Focus Group on Tephrochronology and Volcanism (INTAV), pp. $71-75$.

Moriwaki, H., Machida, H., Nakamura, N., Lowe, D.J., 2010b. The role of tephras in developing a high-resolution chronology for palaeoenvironmental reconstruction and archaeology in southern Kyushu, Japan, since 30,000 years ago (Kyushu-INTIMATE project). Abstracts, International Field Conference on Tephrochronology, Volcanism and Human Activity, Kirishima, Japan (917 May). INQUA International Focus Group on Tephrochronology and Volcanism (INTAV), p.64.

Mortensen, A.K., Bigler, M., Grönvold, K., Steffensen, J.P., Johnsen, S.J., 2005. Volcanic ash layer from the Last Glacial Termination in the NGRIP ice core. Journal of Quaternary Science 20, 209-219.

Nairn, I.A., Shane, P.A.R., Cole, J.W., Leonard, G.J., Self, S., Pearson, N., 2004. Rhyolite magma processes of the c. AD 1315 Kaharoa eruptive episode, Tarawera volcano, New Zealand. Journal of Volcanology and Geothermal Research 131, 265-294.

Naish, T., Kamp, P.J.J., Alloway, B.V., Pillans, B.J., Wilson, G.S., Westgate, J.A., 1996. Integrated tephrochronology and magnetostratigraphy for cyclothemic marine strata, Wanganui 
Basin: implications for the Pliocene-Pleistocene boundary in New Zealand. Quaternary International 34-36, 29-48.

Naish, T.R., Abbott, S.T., Alloway, B.V., Beu, A.G., Carter, R.M., Edwards, A.R., Journeaux, T.D., Kamp, P.J.J., Pillans, B.J., Saul, G., Woolfe, K.J., 1998. Astronomical calibration of a Southern Hemisphere Plio-Pleistocene reference section, Wanganui Basin, New Zealand. Quaternary Science Reviews 17, 695-710.

Nakagawa, M., Wada, K., Thordarson, T., Wood, C.P., Gamble, J.A., 1999. Petrologic investigations of the 1995 and 1996 eruptions of Ruapehu volcano, New Zealand: formation of discrete and small magma pockets and their intermittent discharge. Bulletin of Volcanology 61, $15-31$.

Nakamura, Y., Katayama, Y., Hirakawa, K., 2002. Hydration and refractive indices of Holocene tephra glass in Hokkaido, northern Japan. Journal of Volcanology and Geothermal Research $114,499-510$.

Nakamura, T., Okuno, M., Kimura, K., Mitsutani, T., Moriwaki, H., Ishizuka, Y., Kim, K.H., 2007. Application of ${ }^{14} \mathrm{C}$ wiggle-matching to support denrochronological analysis in Japan. Tree-Ring Research 63, 37-46.

Narcisi, B., Vezzoli, L., 1999. Quaternary stratigraphy of distal tephra layers in the Mediterranean - an overview. Global and Planetary Change 21, 31-50.

Narcisi, B., Petit, J.R., Delmonte, B., Basile-Doelsch, I., Maggi, V., 2005. Characteristics and sources of tephra layers in the EPICA-Dome C ice record (East Antarctica): implications for past atmospheric circulation and ice core stratigraphic correlations. Earth and Planetary Science Letters 239, 253-265.

Narcisi, B., Petit, J.R., Delmonte, B., 2010. Extended East Antarctic ice-core tephrostratigraphy. Quaternary Science Reviews 29, 21-27. 
Neall, V.E., Wallace, R.C., Torrence, R., 2008. The volcanic environment for 40,000 years of human occupation on the Willaumez Isthmus, West New Britain, Papua New Guinea. Journal of Volcanology and Geothermal Research 176, 330-343.

Negrini, R.M., Davis, J.O., 1992. Dating late Pleistocene pluvial events and tephras by correlating paleomagnetic secular variation records from the western Great Basin. Quaternary Research 38, 46-59.

Nelson, C.S., 1988. Revised age of a late Quaternary tephra at DSDP site 594 off eastern South Island and some implications for correlation. Geological Society of New Zealand Newsletter $82,35-40$.

Nelson, C.S., Froggatt, P.C., Gosson, G.J., 1985. Nature, chemistry, and origin of late Cenozoic megascopic tephras in Leg 90 cores from the southwest Pacific. In: Kennett, J.P., von der Borch, C.C. et al. (Eds), Initial Reports of the Deep Sea Drilling Project 90, pp. 1160-1173.

Newnham, R.M., Alloway, B.V., 2004. A terrestrial record of Last Interglacial climate preserved by voluminous debris avalanche inundation in Taranaki, New Zealand. Journal of Quaternary Science 19, 299-314.

Newnham, R.M., Lowe, D.J., 1999. Testing the synchroneity of pollen signals using tephrostratigraphy. Global and Planetary Change 21, 113-128.

Newnham, R.M., Lowe, D.J., 2000. Fine-resolution pollen record of late-glacial climate reversal from New Zealand. Geology 28, 759-762.

Newnham, R.M., de Lange, P.J., Lowe, D.J., 1995a. Holocene vegetation, climate, and history of a raised bog complex, northern New Zealand, based on palynology, plant macrofossils and tephrochronology. The Holocene 5, 267-282.

Newnham, R.M., Lowe, D.J., Wigley, G.N.A., 1995b. Late Holocene palynology and palaeovegetation of tephra-bearing mires at Papamoa and Waihi Beach, western Bay of Plenty, North Island, New Zealand. Journal of the Royal Society of New Zealand 25, 283-300. 
Newnham, R.M., Lowe, D.J., Matthews, B.W., 1998a. A late Holocene and prehistoric record of environmental change from Lake Waikaremoana, New Zealand. The Holocene 8, 443-454.

Newnham, R.M., Lowe, D.J., McGlone, M.S., Wilmshurst, J.M., Higham, T.F.G., 1998b. The Kaharoa Tephra as a critical datum for earliest human impact in northern New Zealand. Journal of Archaeological Science 25, 533-544.

Newnham, R.M., Lowe, D.J., Alloway, B.V., 1999a. Volcanic hazards in Auckland, New Zealand: a preliminary assessment of the threat posed by central North Island silicic volcanism based on the Quaternary tephrostratigraphical record. Geological Society (London) Special Publications 161, 27-45.

Newnham, R.M., Lowe, D.J., Williams, P.W., 1999b. Quaternary environmental change in New Zealand: a review. Progress in Physical Geography 23, 567-610.

Newnham, R.M., Eden, D.N., Lowe, D.J., Hendy, C.H., 2003. Rerewhakaaitu Tephra, a land-sea marker for the Last Termination in New Zealand, with implications for global climate change. Quaternary Science Reviews 22, 289-308.

Newnham, R.M., Lowe, D.J., Green, J.D., Turner, G.M., Harper, M.A., McGlone, M.S., Stout, S. L., Horie, S., Froggatt, P.C., 2004. A discontinuous ca. 80 ka record of Late Quaternary environmental change from Lake Omapere, Northland, New Zealand. Palaeogeography, Palaeoclimatology, Palaeoecology 207, 165-198.

Newnham, R.M., Lowe, D.J., Giles, T.M., Alloway, B.V., 2007a. Vegetation and climate of Auckland, New Zealand, since ca. 32000 cal. yr ago: support for an extended LGM. Journal of Quaternary Science 22, 517-534.

Newnham, R.M., Vandergoes, M.J., Garnett, M.H., Lowe, D.J., Prior, C., Almond, P.C., $2007 b$. Test of AMS ${ }^{14} \mathrm{C}$ dating of pollen concentrates using tephrochronology. Journal of Quaternary Science 22, 37-51. 
Newnham, R.M., Dirks, K.M., Samaranayake, D., 2010. An investigation into long-distance health impacts of the 1996 eruption of Mt Ruapehu, New Zealand. Atmospheric Environment $44,1568-1578$.

Newton, A.J., Dugmore, A.J., Gittings, B.M., 2007. Tephrabase: tephrochronology and the development of a centralized European database. Journal of Quaternary Science 22, 737-743.

Nicol, A., Walsh, J., Berryman, K., Villamor, P., 2006. Interdependence of fault displacement rates and paleoearthquakes in an active rift. Geology 34, 865-868.

Ohkushi, K., Uchida, M., Aoki, K., Yoneda, M., Ikehara, K., Monoshima, K., Kawahata, H., Tada, R., Murayama, M., Shibata, Y., 2007. Radiocarbon marine reservoir ages in the northwestern Pacific off Hokkaido Island, Japan, during the last deglacial period. Radiocarbon, 49, 963-968.

Óladóttir, B.A., Sigmarsson, O., Larsen, G., Thordarson, T., 2008. Katla volcano, Iceland: magma composition, dynamics and eruption frequency as recorded by Holocene tephra layers. Bulletin of Volcanology 70, 475-493.

Olsen, J., Gudmundsdóttir, E.R., Björck, S., Odgaard, B.V., Heinemeier, J., 2010. Revised age estimate of the Mjáuvótn tephra A on the Faroe Islands based on Bayesian modelling of ${ }^{14} \mathrm{C}$ dates from two lake sequences. Journal of Quaternary Science 25, 612-616.

Page, M.J., Trustrum, N.A., 1997. A late Holocene lake sediment record of the erosion response to land use change in a steepland catchment, New Zealand. Zeitschrift für Geomorphologie 41, 369-392.

Page, M.J., Trustrum, N.A., Orpin, A.R., Carter, L., Gomez, B., Cochran, U.A., Mildenhall, D.C. Rogers, K.M., Brackley, H.L., Palmer, A.S., Northcote, L., 2010. Storm frequency and magnitude in response to Holocene climate variability, Lake Tutira, north-eastern New Zealand. Marine Geology 270, 30-44.

Palais, J.M., Kirchner, S., Delmas,R.J., 1990. Identification of some global volcanic horizons by major element analysis of fine ash in Antarctic ice. Annals of Glaciology 14, 216-220. 
Palais, J.M., Germani, M.S., Zielinski, G.A., 1992. Inter-hemispheric transport of volcanic ash from a 1259 A.D. volcanic eruption to the Greenland and Antarctic ice sheets. Geophysical Research Letters 19, 801-804.

Palmer, A.S., Pillans, B.J., 1996. Record of climatic fluctuations from ca. 500 ka loess deposits and paleosols near Wanganui, New Zealand. Quaternary International 34-36, 155-162.

Paterne, M., Guichard, F., Duplessy, J.C., Siani, G., Sulpizio, R., Labeyrie, J., 2008. A 90,000200,000 yrs marine tephra record of Italian volcanic activity in the central Mediterranean Sea. Journal of Volcanology and Geothermal Research 177, 187-196.

Payne, R., Blackford, J., 2005. Simulating the impacts of distal volcanic products upon peatlands in northern Britain: an experimental study on the Moss of Achnacree, Scotland. Journal of Archaeological Science 32, 989-1001.

Payne, R.J., Gehrels, M.J., 2010. The formation of tephra layers in peatlands: an experimental approach. Catena 81, 12-23.

Payne, R.J., Kilfeather, A.A., van der Meer, J.J.M., Blackford, J.J., 2005. Experiments on the taphonomy of tephra in peat. Suo (Mires and Peat) 56, 147-156.

Payne, R., Blackford, J., van der Plicht, J., 2008. Using cryptotephras to extend regional tephrochronologies: an example from southeast Alaska and implications for hazard assessment. Quaternary Research 69, 24-55.

Pearce, N.J.G., Westgate, J.A., Perkins, W.T., 1996. Developments in the analysis of volcanic glass shards by laser ablation ICP-MS: quantitative and single internal standard multi-element methods. Quaternary International 34-36, 213-227.

Pearce, N.J.G., Perkins, W.T., Westgate, J.A., Gorton, M.P., Jackson, S.E., Neal, C.R., Chenery, S.P., 1997. A compilation of new and published major and trace element data for NIST SRM 610 and NIST SRM 612 glass reference materials. Geostandards Newsletter 21, 115-144. 
Pearce, N.J.G., Westgate, J.A., Perkins, W.T., Eastwood, W.J., Shane, P.A.R., 1999. The application of laser ablation ICP-MS to the analysis of volcanic glass shards from tephra deposits: bulk glass and single shard analysis. Global and Planetary Change 21,151-171.

Pearce, N.J.G., Eastwood, W.J., Westgate, J.A., Perkins, W.T., 2002. Trace-element composition of single glass shards in distal Minoan tephra from SW Turkey. Journal of the Geological Society $159,545-557$.

Pearce, N.J.G., Westgate, J.A., Perkins, W.T., Preece, S.J., 2004a. The application of IC-PMS methods to tephrochronological problems. Applied Geochemistry 19, 289-322.

Pearce, N.J.G., Westgate, J.A., Preece, S.J., Eastwood, W.J., Perkins, W.T., 2004b. Identification of Aniakchak (Alaska) tephra in Greenland ice core challenges the 1645 BC date of Minoan eruption of Santorini. Geochemistry, Geophysics, Geosystems 5, Q03005. doi:

10.1029/2003GC000672.

Pearce, N.J.G., Denton, J.S., Perkins, W.T., Westgate, J.A., Alloway, B.V., 2007. Correlation and characterisation of individual glass shards from tephra deposits using trace element laser ablation ICP-MS analyses: current status and future potential. Journal of Quaternary Science $22,721-736$.

Pearce, N.J.G., Bendall, C.A., Westgate, J.A., 2008a. Comment on "Some numerical considerations in the geochemical analysis of distal microtephra" by A.M. Pollard, S.P.E. Blockley and C.S. Lane, Applied Geochemistry, vol. 21, p.1692-1714. Applied Geochemistry 23, 1353-1364.

Pearce, N.J.G., Alloway, B.V., Westgate, J.A., 2008b. Mid-Pleistocene silicic tephra beds in the Auckland region, New Zealand: their correlation and origins based on the trace element analyses of single glass shards. Quaternary International 178, 16-43.

Pearce, N. J. G., Perkins, W. T., Westgate, J. A., Wade, S. C., 2010. Trace-element microanalysis by LA-ICP-MS: the quest for comprehensive chemical characterisation of single, sub-10 $\mu \mathrm{m}$ volcanic glass shards. Abstracts, International Field Conference on Tephrochronology, 
Volcanism, and Human Activity, Kirishima, Japan (9-17 May). INQUA International Focus Group on Tephrochronology and Volcanism (INTAV), pp.77-78.

Perkins, M.E., Nash, W.P., Brown, F.H., Fleck, R.J., 1995. Fallout tuffs of Trapper Creek, Idaho - a record of Miocene explosive volcanism in the Snake River Plain volcanic province. Geological Society of America Bulletin 107, 1484-1506.

Perkins, M.E., Brown, F.H., Nash, W.P., McIntosh, W., Williams, S.K., 1998. Sequence, age, and source of silicic fallout tuffs in middle to late Miocene basins of the northern Basin and Range province. Geological Society of America Bulletin 110, 344-360.

Peters, J.L., Murray, R.W., Sparks, J.W., Coleman, D.S., 2000. Terrigenous matter and dispersed ash in sediments from the Caribbean Sea: results from Leg 165. In: Leckie, R.M., Sigurdsson, H., Acton, G.D., Draper, G. (Ed.), Proceedings of the Ocean Drilling Program, Scientific Results 165, 115-124.

Peters, C., Austin, W.E.N., Walden, J., Hibbert, F.D., 2010. Magnetic characterisation and correlation of a Younger Dryas tephra in North Atlantic marine sediments. Journal of Quaternary Science 25, 339-347.

Pickrill, R.A., Nelson, C.S., Stoffers, P., Craig, G.G.P., 1991. Influence of late Holocene pyroclastic eruptions on the sedimentary geochemistry of Lake Rotoiti, North Island, New Zealand. Journal of Paleolimnology 6, 173-192.

Pillans, B.J., 2003. Subdividing the Pleistocene using the Matuyama-Brunhes boundary (MBB): an Australasian perspective. Quaternary Science Reviews 22, 1569-1577.

Pillans, B.J., McGlone, M.S., Palmer, A.S., Mildenhall, D.C., Alloway, B.V., Berger, G.W., 1993. The Last Glacial Maximum in central and southern North Island, New Zealand: a palaeoenvironmental reconstruction using the Kawakawa Tephra Formation as a chronostratigraphic marker. Palaeogeography, Palaeoclimatology, Palaeoecology 101, 283304. 
Pillans, B.J., Roberts, A.P., Wilson, G.S., Abbott, S.T., Alloway, B.V., 1994.

Magnetostratigraphic, lithostratigraphic and tephrostratigraphic constraints on Lower and

Middle Pleistocene sea-level changes, Wanganui Basin, New Zealand. Earth and Planetary Science Letters 121, 81-98.

Pillans, B.J., Kohn, B.P., Berger, G., Froggatt, P.C., Duller, G., Alloway, B.V., Hesset, P., 1996. Multi-method dating comparison for mid-Pleistocene Rangitawa Tephra, New Zealand. Quaternary Science reviews 15, 641-653.

Pillans, B., Alloway, B.V., Naish, T., Westgate, J.A., Abbot, S., Palmer, A.S., 2005. Silicic tephras in Pleistocene shallow marine sediments of Wanganui Basin, New Zealand. Journal of the Royal Society of New Zealand 35, 43-90.

Pinti, D.L., Rouchon, V., Quidelleur, X., Gillot, P.-Y., Chiesa, S., Ravazzi, C., 2007. Comment: Tephrochronological dating of varved interglacial lake deposits from Piànico-Sèllere (Southern Alps, Italy) to around 400 ka by Brauer, A., Wulf, S., Mangili, C., Moscariello, A. Journal of Quaternary Science 22, 411-414.

Placzek, C., Quade, J., Rech, J.A., Patchett, P.J., Pérez de Arce, C., 2009. Geochemistry, chronology and stratigraphy of Neogene tuffs of the central Andean region. Quaternary Geochronology 4, 22-36.

Platz, T., Cronin, S.J., Smith, I.E.M., Turner, M.B., Stewart, R.B., 2007. Improving the reliability of microprobe-based analyses of andesitic glasses for tephra correlation. The Holocene 17, $573-583$.

Pollard, A.M., Blockley, S.P.E., Ward, K.R., 2003. Chemical alteration of tephra in the depositional environment: theoretical stability modelling. Journal of Quaternary Science 18, 385-394.

Pollard, A. M., Blockley, S. P. E., Lane, C. S., 2006. Some numerical considerations in the geochemical analysis of distal microtephra. Applied Geochemistry 21, 1692-1714. 
Potts, P.J., Thompson, M., Wilson, S., 2002. G-Probe-1 - an international proficiency test for microprobe laboratories - report on round 1: February 2002 (TB-1 basaltic glass). Journal of Geostandards and Geoanalysis 26, 197-235.

Preece, S.J., Westgate, J.A., Stemper, B.A., Péwé, T.L., 1999. Tephrochronology of late Cenozoic loess at Fairbanks, central Alaska. Geological Society of America Bulletin 111, 7190.

Preece, S.J., Westgate, J.A., Alloway, B.V., Milner, M.W., 2000. Characterization, identity, distribution, and source of late Cenozoic tephra beds in the Klondike district of the Yukon, Canada. Canadian Journal of Earth Sciences 37, 983-996.

Preece, S.J., Pearce, N.J.G., Westgate, J.A., Froese, D.G., Jensen, B.J.L., Perkins, W.T., in press. Old Crow tephra across eastern Beringia: a single cataclysmic eruption at the close of Marine Isotope Stage 6. Quaternary Science Reviews. doi:10.1016/j.quascirev.2010.04.020. Pyle, D.M., 1998. How did the summer go? Nature 393, 415-417.

Pyle, D.M., Ricketts, G.D., Margarib, V., van Andel, T.H, Sinitsyn, A.A., Praslov, N.D., Lisitsyn, S., 2006. Quaternary wide dispersal and deposition of distal tephra during the Pleistocene 'Campanian Ignimbrite/Y5' eruption, Italy. Quaternary Science Reviews 25, 2713-2728.

Pyne-O’Donnell, S.D.F., Blockley, S.P.E., Turney, C.S.M., Lowe, J.J., 2008. Distal volcanic ash layers in the Lateglacial Interstadial (GI-1): problems of stratigraphic discrimination. Quaternary Science Reviews 27, 72-84.

Pyne-O’Donnell, S.D.F., in press. The taphonomy of Last Glacial-Interglacial Transition (LGIT) distal volcanic ash in small Scottish lakes. Boreas. doi: 10.1111/j.1502-3885.2010.00154.x.

Rasmussen, T.L., Wastegård, S., Kuijpers, A., van Weering, T.C.E., Heinemeier, J., Thomsen, E., 2003. Stratigraphy and distribution of tephra layers in marine sediment cores from the Faeroe Islands, North Atlantic. Marine Geology 199, 263-277. 
Rasmussen, S.O., Seierstad, I.K., Anderson, K.K., Bigler, M., Dahl-Jensen, D., Johnsen, S.J., 2008. Synchronization of the NGRIP, GRIP, and GISP2 ice cores across MIS 2 and palaeoclimatic implications. Quaternary Science Reviews 27, 18-28.

Reed, S.J.B., 2005. Electron Microprobe Analysis and Scanning Electron Microscopy in Geology ( $2^{\text {nd }}$ edition). Cambridge University Press, Cambridge, UK, pp. 1-206.

Révillon, S., Etoubleau, J., Dennielou, B., Berné, S., Hémond, C., 2010. Can we detect microtephra layers in marine sediment cores using XRF core scanner technology? Abstracts, ITRAX 2010, Applications, innovations and future developments, Lipari, Italy (12-14 April), p. 29-30.

Reyes, A.V., Jensen, B.J.L., Zazula, G.D., Ager, T.A., Kuzmina, S., La Farge, C., Froese, D.G., 2010. A late-Middle Pleistocene (Marine Isotope Stage 6) vegetated surface buried by Old Crow tephra at the Palisades, interior Alaska. Quaternary Science Reviews 29, 801-811.

Riede, F., 2008. The Laacher See-eruption (12,920 BP) and material culture change at the end of the Allerød in northern Europe. Journal of Archaeological Science 35, 591-599.

Riede, F., Bazely, O., 2009. Testing the 'Laacher See hypothesis': a health hazard perspective. Journal of Archaeological Science 36, 574-583.

Riede, F., Wheeler, J.M., 2009. Testing the 'Laacher See hypothesis': tephra as dental abrasive. Journal of Archaeological Science 36, 2384-2391.

Robertson, G.B., Prescott, J.R., Hutton, J.T., 1996. Thermoluminescence dating of volcanic activity at Mount Gambier, South Australia. Transactions of the Royal Society of South Australia 120, 7-12.

Robock, A., 2002. Volcanic eruptions. In: Munn, T. (Ed.), Encyclopaedia of Global Environmental Change. Volume 1, The Earth System: Physical and Chemical Dimensions of Global Environmental Change, Wiley, Chichester, pp. 738-744. 
Rodbell, D.T., Bagnato, S., Nebolini, J.C., Seltzer, G.O., Abbott, M.B., 2002. A late glacialHolocene tephrochronology for glacial lakes in southern Ecuador. Quaternary Research 57, 343-354.

Rogers, K.L., Larson, E.E., 1992. Pliocene and Pleistocene sedimentation in south-central Colorado: opportunity for climate studies. Quaternary International 13-14, 15-18.

Rose, W.I., Chesner, C.A., 1987. Dispersal of ash in the great Toba eruption, 75 ka. Geology 15, 915-917.

Rose, W.I., Durant, A.J., 2009. Fine ash content of explosive eruptions. Journal of Volcanology and Geothermal Research 186, 32-39.

Rose, N.L., Golding, P.N.E., Battarbee, R.W., 1996. Selective concentration and enumeration of tephra shards from lake sediment cores. The Holocene 6, 243-246.

Rose, K.A., Sikes, E.L., Guilderson, T.P., Shane, P., Hill, T.M., Zahn, R., Spero, H.J., 2010. Upper-ocean-to-atmosphere radiocarbon offsets imply fast deglacial carbon dioxide release. Nature 466, 1093-1096.

Ross, K.A., Fisher, R.V., 1986. Biogenic grooving on glass shards. Geology 14, 571-573.

Roulleau, E., Pinti, D.L., Rouchon, V., Quidelleur, X., Gillot, P.-Y., 2009. Tephrochronostratigraphy of the lacustrine interglacial record of Piànico, Italian southern Alps: identifying the volcanic sources using radiogenic isotopes and trace elements. Quaternary International 204, 31-43.

Saminger, S., Peltz, C., Bichler, M., 2000. South Aegean volcanic glass: separation and analysis by INAA and EPMA. Journal of Analytical and Nuclear Chemistry 245, 375-383.

Samson, S.D., Matthews, S., Mitchell, C.E., Goldman, D., 1995. Tephrochronology of highly altered ash beds: the use of trace element and strontium isotope geochemistry of apatite phenocrysts to correlate K-bentonites. Geochimica et Cosmochimica Acta 59, 2527-2536. 
Sanborne, P.T., Smith, C.A.S., Froese, D.G., Zazula, G., Westgate, J.A., 2006. Full-glacial paleosols in perenially frozen loess sequences, Klondike goldfields, Yukon Territory, Canada. Quaternary Research 66, 147-157.

Sandhu, A.S., Westgate, J.A., Stemeper, B.A., 1992. Isothermal plateau correction for partial fading of fission tracks in hydrated glass shards. Quaternary International 13-14, 121-125.

Sandhu, A.S., Westgate, J.A., Alloway, B.V., 1993. Optimizing the isothermal plateau fission track dating method for volcanic glass shards. Nuclear tracks 21, 479-488.

Santos, G.M., Bird, M.I., Pillans, B., Fifield, L.K., Alloway, B.V., Chappell, J., Hausladen, P.A., Arneth, A., 2001. Radiocarbon dating of wood using different pre-treatment procedures: application to the chronology of Rotoehu ash, New Zealand. Radiocarbon 43, 239-248.

Sarna-Wojcicki, A.M., 2000. Tephrochronology. In: Noller, J.S., Sowers, J.M., Lettis, W.R., (Eds), Quaternary Geochronology: Methods and Applications. American Geophysical Union Washington, DC, AGU Reference Shelf 4, 357-377.

Sarna-Wojcicki, A.M., Shipley, S., Waitt, R.B., Jr., Dzurisin, D., Wood, S.H., 1981a. Area distribution, thickness, mass, volume, and grain size of air-fall ash from the six major eruptions of 1980. In: Lipman, P.W., Mullineaux, D.R. (Ed.), The 1980 Eruptions of Mount St. Helens, Washington. Geological Survey Professional Paper 1250, 577-600.

Sarna-Wojcicki, A.M., Meyer, C.E., Woodward, M.J., Lamothe, P.J., 1981b. Comparison of airfall ash erupted on May 18, May 25, June 12, July 22, and August 7. In: Lipman, P.W., Mullineaux, D.R. (Ed.), The 1980 Eruptions of Mount St. Helens, Washington. Geological Survey Professional Paper 1250, 667-681.

Sarna-Wojcicki, A.M., Meyer, C.E., Wan, E., 1997. Age and correlation of tephra layers, position of the Matuyama-Bruhnes chron boundary, and effects of Bishop ash eruptions on Owens Lake, as determined from drill hole OL-92, southern California. Geological Society of America Professional Paper 317, 79-90. 
Scasso, R.A., Carey, S., 2005. Morphology and formation of glassy volcanic ash from the August 12-15, 1991 eruption of Hudson Volcano, Chile. Latin American Journal of Sedimentology and Basin Analysis 12, 3-21.

Schiff, C.J., Kaufman, D.S., Wallace, K.L., Ketterer, M.E., 2010. An improved proximal tephrochronology for Redoubt volcano, Alaska. Journal of Volcanology and Geothermal Research 193, 203-214.

Schmitt, A.K., Stockli, D.F., Niedermann, S., Lovera, O.M., Hausback, B.P., 2010. Eruption ages of Las Tres Vírgenes Volcano (Baja California): a tale of two helium isotopes. Quaternary Geochronology 5, 503-511.

Schmitz, M.D., Smith, I.E.M., 2004. The petrology of the Rotoiti eruption sequence, Taupo Volcanic Zone: an example of fractionation and mixing in a rhyolitic system. Journal of Petrology 45, 2045-2066.

Scudder, R.P., Murray, R.W., Plank, T., 2009. Dispersed ash in deeply buried sediment from the northwest Pacific Ocean: an example from the Izu-Bonin arc (ODP Site 1149). Earth and Planetary Science Letters 284, 639-648.

Seward, D., 1979. Comparison of zircon and glass fission track ages from tephra horizons. Geology 7, 479-482.

Shane, P.A.R., 1998. Correlation of rhyolitic pyroclastic eruptive units from the Taupo volcanic zone by Fe-Ti oxide compositional data. Bulletin of Volcanology 60, 224-238.

Shane, P.A.R., 2000. Tephrochronology: a New Zealand case study. Earth-science Reviews 49, 223-259.

Shane, P.A.R., 2005. Towards a comprehensive distal andesitic tephrostratigraphic framework for New Zealand based on eruptions from Egmont volcano. Journal of Quaternary Science 20, 4557. 
Shane, P.A.R., Froggatt, P.C., 1992. Composition of widespread volcanic glass in deep-sea sediments of the southern Pacific Ocean: an Antarctic source inferred. Bulletin of Volcanology $54,595-601$.

Shane, P.A.R., Froggatt, P.C., 1994. Discriminant function analysis of glass chemistry of New Zealand and North American tephra deposits. Quaternary Research 41, 70-81.

Shane, P.A.R., Hoverd, J., 2002. Distal record of multi-sourced tephra in Onepoto Basin, Auckland, New Zealand: implications for volcanic chronology, frequency and hazards. Bulletin of Volcanology 64, 441-454.

Shane, P.A.R., Sandiford, A., 2003. Paleovegetation of marine isotope stages 4 and 3 in northern New Zealand and the age of the widespread Rotoehu tephra. Quaternary Research 59, 420429.

Shane, P.A.R., Smith, I.E.M., 2000. Geochemical fingerprinting of basaltic tephra deposits in the Auckland Volcanic Field. New Zealand Journal of Geology and Geophysics 43, 569-577.

Shane, P.A.R., Black, T., Alloway, B.V., Westgate, J.A., 1996. Early to middle Pleistocene tephrochronology of North Island, New Zealand: implications for volcanism, tectonism and palaeoenvironments. Geological Society of America Bulletin 108, 915-925.

Shane, P.A.R., Froggatt, P.C., Smith, I.E.M., Gregory, M., 1998. Multiple sources for sea-rafted Loisels Pumice, New Zealand. Quaternary Research 49, 271-279.

Shane, P.A.R., Lian, O.B., Augustinus, P., Chisari, R., Heijnis, H., 2002. Tephrostratigraphy and geochronology of a ca. 120 ka terrestrial record at Lake Poukawa, North Island, New Zealand. Global and Planetary Change 33, 221-242.

Shane, P.A.R., Smith, V.C., Lowe, D.J., Nairn, I.A., 2003a. Re-identification of c. 15700 cal yr BP tephra bed at Kaipo Bog, eastern North Island: implications for dispersal of Rotorua and Puketarata tephra beds. New Zealand Journal of Geology and Geophysics 46, 591-596.

Shane, P.A.R., Smith, V., Nairn, I.A., 2003b. Biotite composition as a tool for the identification of Quaternary tephra beds. Quaternary Research 59, 262-270. 
Shane, P.A.R., Nairn, I.A., Smith, V.C., 2005. Magma mingling in the $~ 50$ ka Rotoiti eruption from Okataina Volcanic Centre: implications for geochemical diversity and chronology for large volume rhyolites. Journal of Volcanology and Geothermal Research 139, 295-313.

Shane, P.A.R., Sikes, E.L., Guilderson, T.P., 2006. Tephra beds in deep-sea cores off northern New Zealand: implications for the history of Taupo Volcanic Zone, Mayor Island and White Island volcanoes. Journal of Volcanology and Geothermal Research 154, 276-290.

Shane, P.A.R., Nairn, I.A., Martin, S.B., Smith, V.C., 2008a. Compositional heterogeneity in tephra deposits resulting from the eruption of multiple magma bodies: implications for tephrochronology. Quaternary International 178, 44-53.

Shane, P.A.R., Doyle, L.R., Nairn, I.A., 2008b. Heterogeneous andesite-dacite ejecta in 26-16.6 ka pyroclastic deposits of Tongariro Volcano, New Zealand: the product of multiple magmamixing events. Bullletin of Volcanology 70, 517-536.

Sharp, T.G., Stevenson, R.J., Dingwell, D.B., 1996. Microlites and "nanolites" in rhyolitic glass: microstructural and chemical characterisation. Bulletin of Volcanology 57, 631-640.

Sheard, M.J., 1990. A guide to Quaternary volcanoes in the lower south-east of South Australia. Mines and Energy Review South Australia 157, 40-50.

Sheard, M.J., 1995. Quaternary volcanic activity and volcanic hazards. In: Drexel, J.F., Preiss, W.V. (Eds), The Geology of South Australia, Vol. 2. South Australia Geological Survey Bulletin 54, pp. 264-268.

Sheard, M.J., Lowe, D.J., Froggatt, P.C., 1993. Mineralogy of pyroclastic and lava deposits of Holocene basaltic volcanoes of Mts Gambier and Schank, South Australia. Abstracts, IAVCEI International Volcanological Congress, Canberra, p. 98.

Sheppard, P., Ort, M., Anderson, K., Clynne, M., May, E., 2009. Multiple dendrochronological responses to the eruption of Cinder Cone, Lassen Volcanic National Park, California. Dendrochronologia 27, 213-221. 
Sigurdsson, H. (Ed.) 2000. Encyclopaedia of Volcanoes. Academic Press, San Diego, CA, pp. 11417.

Sigurdsson, H., Sparks, R.S.J., Cary, S.N., Huang, T.C., 1980. Volcanogenic sedimentation in the Lesser Antilles arc. Journal of Geology 88, 523-540.

Sikes, E.L., Samson, C.R., Guilderson, T.P., Howard, W.R., 2000. Old radiocarbon ages in the southwest Pacific Ocean during the last glacial period and deglaciation. Nature 405, 555-559.

Simpson, I. A., Dugmore, A.J., Thomson, A.M., Vésteinsson, O., 2001. Crossing the thresholds: human ecology and historical patterns of landscape degradation. Catena 42, 176-192.

Smellie, J.L., 1999. The upper Cenozoic tephra record in the south polar region: a review. Global and Planetary Change 21, 51-70.

Smith, D.R., Leeman, W.P., 1982. Mineralogy and phase chemistry of Mount St. Helens tephra sets W and Y as keys to their identification. Quaternary Research 17, 211-227.

Smith, V.C., Shane, P.A.R., Smith, I.E.M., 2002. Tephrostratigraphy and geochemical fingerprinting of the Mangaone Subgroup tephra beds, Okataina Volcanic Centre, New Zealand. New Zealand Journal of Geology and Geophysics 45, 207-219.

Smith, V.C., Shane, P., Nairn, I.A., 2005. Trends in rhyolite geochemistry, mineralogy, and magma storage during the last $50 \mathrm{kyr}$ at Okataina and Taupo volcanic centres, Taupo Volcanic Zone, New Zealand. Journal of Volcanology and Geothermal Research 148, 372-406.

Smith, V.C., Shane, P.A.R., Nairn, I.A., Williams, C.M., 2006. Geochemistry and magmatic properties of eruption episodes from Haroharo linear vent zone, Okataina Volcanic Centre, New Zealand during the last 10 kyr. Bulletin of Volcanology 69, 57-88.

Snyder, D.C., Widom, E., Pietruszka, A.J., Carlson, R.W., 2004. The role of open-system processes in the development of silicic magma chambers: a chemical and isotopic investigation of the Fogo A trachyte deposit, São Miguel, Azores. Journal of Petrology 45, 723-738. 
Soles, J.S., Taylor, S.R., Vitaliano, C.J., 1995. Tephra samples from Mochlos and their chronological implication for Neopalatial Crete. Archaeometry 37, 385-393.

Sparks, R.S.J., Bursik, M.I., Carey, S.N., Gilbert, J.S., Glaze, L.S., Sigurdsson, H., Woods, A.W., 1997. Volcanic Plumes. Wiley, Chichester, pp.1-590.

Spinettt, C., Mazzarini, F., Casacchia, R., Colini, L., Neri, M., Behncke, B., Salvatori, R., Buongiorno, M.F., Pareschi, M.T., 2009. Spectral properties of volcanic materials from hyperspectral field and satellite data compared with LiDAR data at Mt. Etna. International Journal of Applied Earth Observation and Geoinformation 11, 142-155.

Stanton, T., Snowball, I., Zillén, L., Wastegård, S., in press. Validating a Swedish varve chronology using radiocarbon, palaeomagnetic secular variation, lead pollution history and statistical correlation. Quaternary Geochronology. doi: 10.1016/j.quageo.2010.03.004.

Stern, C.R., 2008. Holocene tephrochronology record of large explosive eruptions in the southernmost Patagonian Andes. Bulletin of Volcanology 70, 435-454.

Stevenson, C.M., Sheppard, P.J., Sutton, D.G., Ambrose, W., 1996. Advances in the hydration dating of New Zealand obsidian. Journal of Archaeological Science 23, 233-242.

Stihler, S.D., Stone, D.B., Begét, J.E., 1992. Varve counting vs tephrochronology and Cs-137 and Pb-210 dating: a comparative test at Skilak Lake, Alaska. Geology 20, 1019-1022.

Stokes, S., Lowe, D.J., 1988. Discriminant function analysis of late Quaternary tephras from five volcanoes in New Zealand using glass shard major element chemistry. Quaternary Research $30,270-283$.

Stokes, S., Lowe, D.J., Froggatt, P.C., 1992. Discriminant function analysis and correlation of late Quaternary rhyolitic tephra deposits from Taupo and Okataina volcanoes, New Zealand, using glass shard major element composition. Quaternary International 13-14, 103-117.

Stollhofen, R., Stanistreet, I.G., McHenry, L.J., Mollel, G.F., Blumenschine, R.J., Masao, F.T., 2008. Fingerprinting facies of the Tuff IF marker, with implications for early hominin 
palaeoecology, Olduvai Gorge, Tanzania. Palaeogeography, Palaeoclimatology,

Palaeoecology 259, 382-409.

Sutton, D.G., 1987. A paradigmatic shift in Polynesian prehistory: implications for New Zealand. New Zealand Journal of Archaeology 9, 135-155.

Sutton, A.W., Blake, S., Wilson, C.J.N., Charlier, B.L.A., 2000. Late Quaternary evolution of a hyperactive rhyolite magmatic system: Taupo volcanic centre, New Zealand. Journal of the Geological Society, London 157, 537-552.

Sutton, D.G., Flenley, J.R., Li, X., Todd, A., Butler, K., Summers, R., Chester, P.I., 2008. The timing of the human discovery and colonization of New Zealand. Quaternary International $184,109-121$.

Suzuki, T., 1996. Chemical analysis of volcanic glass by energy dispersive X-ray spectrometry with JEOL JED-2001 and JSM-5200: analytical procedures and application. Geographical Reports of Tokyo Metropolitan University 31, 27-36.

Suzuki, T., 2008. Analysis of titanomagnetite within weathered middle Pleistocene KMT tephra and its application for fluvial terrace chronology, Kanto Plain, central Japan. Quaternary International 178, 119-127.

Suzuki, T., Koarai, M., Nakayama, D., 2010. Construction of Japanese tephra database using GIS. Abstracts, International Field Conference on Tephrochronology, Volcanism and Human Activity, Kirishima, Japan (9-17 May). INQUA International Focus Group on Tephrochronology and Volcanism (INTAV), p. 84.

Svensson, A., Andersen, K.K., Bigler, M., Clausen, H.B., Dahl-Jensen, D., Davies, S.M., Johnsen, S.J., Muscheler, R., Parrenin, F., Rasmussen, S.O., Röthlisberger, R., Seierstad, I., Steffensen, J.P., Vinther, B.M., 2008. A 60000 year Greenland stratigraphic ice core chronology. Climate of the Past, 4, 47-57. 
Takemura, K., Hayashida, A., Okamura, M., Matsuoka, H., Mohammed Ali, M., Kuniko, Y., Torii, M., 2000. Stratigraphy of multiple piston core sediments for the last 30,000 years from Lake Biwa, Japan. Journal of Paleolimnology 23, 185-199.

Telford, R.J., Barker, P., Metcalf, S., Newton, A., 2004. Lacustrine responses to tephra deposition: examples from Mexico. Quaternary Science Reviews 23, 2337-2353.

Thompson, R., Bradshaw, R.H.W., Whitley, J.E., 1986. The distribution of ash in Icelandic lake sediments and the relative importance of mixing and erosion processes. Journal of Quaternary Science 1, 3-11.

Thorarinsson, S., 1981. Tephra studies and tephrochronology: a historical review with special reference to Iceland. In: Self, S., Sparks, R.S.J. (Eds.), Tephra Studies. Reidel, Dordrecht, pp. $1-12$.

Thorseth, I.H., Furnes, H., Heldal, M., 1992. The importance of microbiological activity in the alteration of natural basaltic glass. Geochimica et Cosmochimica Acta 56, 845-850.

Thouret, J.-C., Juvigné, E., Gourgaud, A., Boivin, P., Dávila, J., 2002. Reconstruction of the AD 1600 Huaynaputina eruption based on the correlation of geologic evidence with early Spanish chronicles. Journal of Volcanology and Geothermal Research 115, 529-570.

Toms, P.S., King, M., Zárate, M.A., Kemp, R.A., Foit, F.F., Jr., 2004. Geochemical characterization, correlation, and optical dating of tephra in alluvial sequences of central western Argentina. Quaternary Research 62, 60-75.

Ton-That, T., Singer, B., Paterne, M., 2001. ${ }^{40} \mathrm{Ar} /{ }^{39} \mathrm{Ar}$ dating of latest Pleistocene (41 ka) marine tephra in the Mediterranean Sea: implications for global climate records. Earth and Planetary Science Letters 184, 645-658.

Toyoda, S., Tsukamoto, S., Hameau, S., Usui, H., Suzuki, T., 2006. Dating of Japanese Quaternary tephras by ESR and luminescence methods. Quaternary Geochronology 1, 320326. 
Traufetter, F., Oerter, H., Fischer, H., Weller, R., Miller, H., 2004. Spatio-temporal variability in volcanic sulphate deposition over the past $2 \mathrm{kyr}$ in snow pits and firn cores from Amundsenisen, Antarctica. Journal of Glaciology 50, 137-146.

Trepte C.R., Hitchman, M.H., 1992. Tropical stratospheric circulation deduced from satellite aerosol data. Nature 355, 626-628.

Tryon, C.A., McBrearty, S., 2002. Tephrostratigraphy and the Acheulian to Middle Stone Age transition in the Kapthurin Formation, Kenya. Journal of Human Evolution 42, 211-235.

Tryon, C.A., Roach, N.T., Logan, M.A.L., 2008. The Middle Stone Age of the northern Kenyan Rift: age and context of new archaeological sites from the Kapedo Tuffs. Journal of Human Evolution 55, 652-664.

Tryon, C.A., Logan, M.A.V., Mouralis, D., Kuehn, S., Slimak, L., Balkan-Atl1, N., 2009. Building a tephrostratigraphic framework for the Paleolithic of central Anatolia, Turkey. Journal of Archaeological Science 36, 637-652.

Tryon, C.A., Faith, J.T., Peppe, D.J., Fox, D.L., Jenkins, K., Dunsworth, H., Harcourt-Smith, W., in press. The Pleistocene archaeology and environments of the Wasiriya Beds, Rusinga Island, Kenya. Journal of Human Evolution (doi:10.1016/j.jhevol.2010.07.020)

Turner, M., Cronin, S., Bebbington, M., Platz, T., 2008a. Developing probabilistic eruption forecasts for dormant volcanoes: a case study from Mt Taranaki, New Zealand. Bulletin of Volcanology 70, 507-515.

Turner, M., Cronin, S.J., Stewart, R.B., Bebbington, M., Smith I.E.M.., 2008b. Using titanomagnetite textures to elucidate volcanic eruption histories. Geology 36, 31-34.

Turner, M.B., Bebbington, M.S., Cronin, S.J., Stewart, R.B., 2009. Merging eruption datasets: building an integrated Holocene eruptive record for Mt Taranaki, New Zealand. Bulletin of Volcanology 71, 903-918.

Turney, C.S.M., 1998. Extraction of rhyolitic component of Vedde microtephra from minerogenic lake sediments. Journal of Paleolimnology 19, 199-206. 
Turney, C.S.M., Lowe, J.J., 2001. Tephrochronology. In: Last, W.M., Smol, J.P. (Eds.), Tracking Environmental Changes in Lake Sediments: Physical and Chemical Techniques. Kluwer Academic, Dordrecht, pp. 451-471.

Turney, C.S.M., Lowe, J.J., Davies, S.M., Hall, V.A., Lowe, D.J., Wastegård, S., Hoek, W.Z., Alloway, B.V., 2004. Tephrochronology of Last Termination sequences in Europe: a protocol for improved analytical precision and robust correlation procedures (a joint SCOTAVINTIMATE proposal). Journal of Quaternary Science 19, 111-120.

Turney, C.S.M., van den Burg, K., Wastegård, S., Davies, S.M., Whitehouse, N.J., Pilcher, J.R., Callaghan, C., 2006. North European last glacial-interglacial transition (LGIT; 15-9 ka) tephrochronology: extended limits and new events. Journal of Quaternary Science 21, 335345.

Turney, C.S.M., Blockley, S.P.E., Lowe, J.J., Wulf, S., Branch, N.P., Mastrolorenzo, G., Swindle, G., Nathan, R., Pollard, A.M., 2008. Geochemical characterization of Quaternary tephras from the Campanian Province, Italy. Quaternary International 178, 288-305. van den Bogaard, P., 1995. ${ }^{40} \mathrm{Ar} /{ }^{39} \mathrm{Ar}$ ages of sanidine phenocrysts from Laacher See Tephra (12,900 yr BP): chronostratigraphic and petrological significance. Earth and Planetary Science Letters 133, 163-174.

van den Bogaard, C., Schmincke, H.-U., 2002. Linking the North Atlantic to central Europe: a high resolution tephrochronological record from northern Germany. Journal of Quaternary Science 17, 3-20.

van den Bogaard, C., Dorfler, W., Sandgren, P., Schmincke, H.-U., 1994. Correlating the Holocene records: Icelandic tephra found in Schleswig-Holstein (Northern Germany). Naturwissenschaften 81, 554-556.

Venuti, A., Verosub, K.L., 2010. Paleomagnetic record of basaltic volcanism from Pukaki and Onepoto maar lake cores, Auckland Volcanic Field, New Zealand. New Zealand Journal of Geology and Geophysics 53, 71-79. 
Veres, D., Davies, S.M., Wohlfarth, B., Preusser, F., Wastegård, S., Ampel, L., Hormes, A., Possnert, G., Raynal, J.-P., Vernet, G., 2008. Age, origin and significance of a new middle MIS 3 tephra horizon identified within a long-core sequence from Les Echets, France. Boreas $37,434-443$.

Verosub, K.L., 1981. The interrelationship between magnetostratigraphy and tephrochronology. In: Self, S., Sparks, R.S.J. (Eds), Tephra Studies. Reidel, Dordrecht, pp. 65-72.

Vinther, B.M., Clausen, H.., Johnsen, S.J., Rasmussen, S.O., Andersen, K.K., Buchardt, S.L., Dahl-Jensen, D., Seierstad, I.K., Siggaard-Andersen, M.-L., Steffensen, J.P., Svensson, A., Olsen, J., Heinemeier, J., 2008. A synchronized dating of three Greenland ice cores throughout the Holocene. Journal of Geophysical Research 113, D12306. doi: 10.1029/2007JD009083.

Vogel, H., Zanchetta, G., Sulpizio, R., Wagner, B., Nowaczyk, N., 2009. A tephrostratigraphic record of the last glacial-interglacial cycle from Lake Ohrid, Albania and Macedonia. Journal of Quaternary Science 25, 320-338.

Vucetich, C.G., Pullar, W.A., 1969. Stratigraphy and chronology of late Pleistocene volcanic ash beds in the central North Island, New Zealand. New Zealand Journal of Geology and Geophysics 12, 784-837.

Wagner, B., Silpizio, R., Zanchetta, G., Wulf, S., Wessels, M., Dauf, G., Nowaczyk, N., 2008. The last 40 ka tephrostratigraphic record of Lake Ohrid, Albania and Macedonia: a very distal archive for ash dispersal from Italian volcanoes. Journal of Volcanology and Geothermal Research 177, 71-80.

Walker, G.P.L., 1981. Generation and dispersal of fine ash and dust by volcanic eruptions. Journal of Volcanology and Geothermal Research 11, 81-92.

Walker, M., Johnsen, S., Rasmussen, S.O., Popp, T., Steffensen, J.-P., Gibbard, P., Hoek, W., Lowe, J.J., Andrews, J., Björck, S., Cwynar, L., Hughen, K., Kershaw, P., Kromer, B., Litt, T., Lowe, D.J., Nakagawa, T., Newnham, R.M., Schwander, J., 2009. Formal definition and dating of the GSSP (Global Stratotype Section and Point) for the base of the Holocene using 
the Greenland NGRIP ice core, and selected auxiliary records. Journal of Quaternary Science 24, 3-17.

Wastegård, S., Davies, S.M., 2009. An overview of distal tephrochronology in northern Europe during the last 1000 years. Journal of Quaternary Science 24, 500-512.

Wastegård, S., Hall, V.A., Hannon, G. E., van den Bogaard, C., Pilcher, J.R., Sigurgeirsson, M.A., Hermanns-Auoardóttir, M., 2003. Rhyolitic tephra horizons in northwestern Europe and Iceland from the $\mathrm{AD} 700 \mathrm{~s}-800 \mathrm{~s}$ : a potential alternative for dating first human impact. The Holocene 13, 277-283.

Wastegård, S., Rasmussen, T.L., Kuijpers, A., Nielsen, T., van Weering, T.C.E., 2006. Composition and origin of ash zones from Marine Isotope Stages 3 and 2 in the North Atlantic. Quaternary Science Reviews 25, 2409-2419.

Watanabe, S., Widom, E., Ui, T., Miyaji, N., Roberts, A.M., 2006. The evolution of a chemically zoned magma chamber: the 1707 eruption of Fuji volcano, Japan. Journal of Volcanology and Geothermal Research 152, 1-19.

Wiesner, M.G., Wang, Y., Zheng, L., 1995. Fallout of volcanic ash to the deep South China Sea induced by the 1991 eruption of Mount Pinatubo (Philippines). Geology 23, 885-888.

Westgate, J.A., 1989. Isothermal plateau fission track ages of hydrated glass shards from silicic tephra beds. Earth and Planetary Science Letters 95, 226-234.

Westgate, J.A., Evans, M.E., 1978. Compositional variability of Glacier Peak Tephra and its stratigraphic significance. Canadian Journal of Earth Sciences 15, 1554-1567.

Westgate, J.A., Gorton, M.P., 1981. Correlation techniques in tephra studies. In: Self, S., Sparks, R.S.J. (Eds), Tephra Studies. Reidel, Dordrecht, pp. 73-94.

Westgate, J.A., Stemper, B.A., Péwé, T.L., 1990. A 3 m.y. record of Pliocene-Pleistocene loess in interior Alaska. Geology 18, 858-861. 
Westgate, J.A., Perkins, W.T., Fuge, R., Pearce, N.J.G., Wintle, A.G., 1994. Trace-element analysis of volcanic glass shards by laser ablation inductively coupled plasma mass spectrometry: application to tephrochronological studies. Applied Geochemistry 9, 323-335.

Westgate, J.A., Preece, S.J., Froese, D.G., Walter, R.C., Sandhu, A.S., Schweger, C.E., 2001. Dating Early and Middle (Reid) Pleistocene glaciations in central Yukon by tephrochronology. Quaternary Research 56, 335-348.

Westgate, J.A., Naeser, N., Alloway, B.V., 2007. Fission-track dating. In: Elias, S.A. (Ed.), Encyclopaedia of Quaternary Science. Elsevier, London, pp. 651-672.

Westgate, J.A., Preece, S.J., Froese, D.G., Pearce, N.J.G., Roberts, R.G., Demuro, M., Hart W.K., Perkins, W., 2008. Changing ideas on the identity and stratigraphic significance of the Sheep Creek tephra beds in Alaska and the Yukon Territory, northwestern North America. Quaternary International 178, 183-209.

Westgate, J.A., Pearce, N.J.G., Perkins, W.T., Shane, P.A.R., Preece, S.J., Sears, J.W., 2010. Pb isotope ratios of volcanic glass: an exploratory study of their value in locating source calderas of widespread tephra beds in Montana and Saskatchewan, NW North America. Abstracts, International Field Conference on Tephrochronology, Volcanism and Human Activity, Kirishima, Japan (9-17 May). INQUA International Focus Group on Tephrochronology and Volcanism (INTAV), p. 96.

Wetzel, A., 2009. The preservation potential of ash layers in the deep-sea: the example of the 1991-Pinatubo ash in the South China Sea. Sedimentology 56, 1992-2009.

White, J.D.L., Houghton, B.F., 2006. Primary volcaniclastic rocks. Geology 34, 677-680.

Wilcox, R.E., Naeser, C.W., 1992. The Pearlette family ash beds in the Great Plains: finding their identities and their roots in the Yellowstone country. Quaternary International 13-14, 9-13.

Williams, M.A.J., Ambrose, S.H., van der Kaars, S., Ruehlemann, C., Chattopadhyaya, U., Pal, J., Chauhan, P.R., 2009. Environmental impact of the 73 ka Toba super-eruption in South Asia. Palaeogeography, Palaeoclimatology, Palaeoecology 284, 295-314. 
Wilmshurst, J.M., Higham, T.F.G., 2004. Using rat-gnawed seeds to independently date the arrival of Pacific rats and humans to New Zealand. The Holocene 14, 801-806.

Wilmshurst, J.M., McGlone, M.S., 1996. Forest disturbance in the central North Island, New Zealand, following the 1850 BP Taupo eruption. The Holocene 6, 399-411.

Wilmshurst, J.M., McGlone, M.S., Partridge, T.R., 1997. A late Holocene history of natural disturbance in lowland podocarp/hardwood forest, Hawke's Bay, New Zealand. New Zealand Journal of Botany 35, 79-96.

Wilmshurst, J.M., Anderson, A.J., Higham, T.F.G., Worthy, T.H., 2008. Dating the late prehistoric dispersal of Polynesians to New Zealand using the commmensal Pacific rat. Proceedings of the National Academy of Sciences of the United States of America105, 76767680.

Wilson, C.J.N., 1993. Stratigraphy, chronology, styles and dynamics of Late Quaternary eruptions from Taupo volcano, New Zealand. Philosophical Transactions of the Royal Society of London A343, 205-306.

Wilson, C.J.N., 2001. The 26.5 ka Oruanui eruption, New Zealand: an introduction and overview. Journal of Volcanology and Geothermal Research 112, 133-174.

Wilson, C.J.N., 2008. Supereruptions and supervolcanoes: processes and products. Elements 4, 29-34.

Wilson, C.J.N., Hildreth, W., 1997. The Bishop Tuff: new insights from eruptive stratigraphy. Journal of Geology 105, 407-439.

Wilson, C.J.N., Houghton, B.F., McWilliams, M.O., Lanphere, M.A., Weaver, S.D., Briggs, R.M., 1995. Volcanic and structural evolution of Taupo Volcanic Zone, New Zealand: a review. Journal of Volcanology and Geothermal Research 68, 1-28.

Wilson, C.J.N., Rhoades, D.A., Lanphere, M.A., Calvert, A.T., Houghton, B.F., Weaver, S.D., Cole, J.W., 2007. A multiple-approach radiometric age estimate for the Rotoiti and Earthquake 
Flat eruptions, New Zealand, with implications for the MIS 4/3 boundary. Quaternary Science Reviews 26, 1861-1870.

Wilson, C.J.N., Gravley, D.M., Leonard, G.S., Rowland, J.V., 2009. Volcanism in the central Taupo Volcanic Zone, New Zealand: tempo, styles and controls. In: Thordarson, T., Self, S., Larsen, G., Rowland, S.K., Hoskuldsson, A. (Eds), Studies in Volcanology: the Legacy of George Walker. Special Publications of IAVCEI (Geological Society, London) 2, pp. 225-247.

Wohlfarth, B., Blaauw, M., Davies, S.M., Andersson, M., Wastegård, S., Hormes, A., Posnert, G., 2006. Constraining the age of Lateglacial and early Holocene pollen zones and tephra horizons in southern Sweden with Bayesian probability methods. Journal of Quaternary Science 21, 321-334.

WoldeGabriel, G., Hart, W.K., Katoh, S., Beyene, Y., Suwa, G., 2005. Correlation of PlioPleistocene tephra in Ethiopian and Kenyan rift basins: temporal calibration of geological features and hominid fossil records. Journal of Volcanology and Geothermal Research 147, 81-108.

Wolff-Boenisch, D., Gislason, S.R., Oelkers, E.H., Putnis, C.V., 2004. The dissolution rates of natural glasses as a function of their composition at $\mathrm{pH} 4$ and 10.6, and temperatures from 25 to $74^{\circ} \mathrm{C}$. Geochimica et Cosmochimica Acta $68,4843-4858$.

Wulf, S., Kraml, M., Brauer, A., Keller, J., Negendank, J.F.W., 2004. Tephrochronology of the 100 ka lacustrine sediment record of Lago Grande di Monticchio (southern Italy). Quaternary International 122, 7-30.

Wulf, S., Kraml, M. and Keller, J., 2008. Towards a detailed distal tephrostratigraphy in the central Mediterranean: the last 20,000 yrs record of Lago Grande di Monticchio. Journal of Volcanology and Geothermal Research 177, 118-132.

Xia, D., Chun, X., Bloemendal, J., Chiverrell, R.C., 2007. Use of magnetic signatures to correlate tephra layers in Holocene loessial soil profiles from a small region, SE Iceland. Environmental Geology 51, 1425-1437. 
Yoshinaga, S., 1992. Variations in rates of accumulation of tropospheric fine quartz in tephra, loess, and associated paleosols since the last intergacial stage, Tokachi Plain, northern Japan, and paleoclimatic inferences. Quaternary International 34-36, 139-146.

Zielinski, G.A., Mayewski, P.A., Meeker, L.D., Whitlow, S., Twickler, M.S., Morrison, M., Meese, D., Alley, R.B., Gow, A.J., 1994. Record of volcanism since 7000 B.C. from the GISP2 Greenland ice core and implications for the volcano-climate system. Science 264, 948952.

Zielinski, G.A., Dibb, J.E., Yang, Q., Mayewski, P.A., Whitlow, S., Twickler, M.S., 1997. Assessment of the record of the $1982 \mathrm{El}$ Chichón eruption as preserved in Greenland snow. Journal of Geophysical Research 102, 30031-30045.

Zillén, L.M., Wastegård, S., Snowball, I.F., 2002. Calendar year ages of three mid-Holocene tephra layers identified in varved lake sediments in west central Sweden. Quaternary Science Reviews 21, 1583-1591. 